\title{
\begin{tabular}{llllllllll} 
II. & $\mathbf{M}$ & $\mathbf{A}$ & $\mathbf{T}$ & $\mathbf{E}$ & $\mathbf{R}$ & $\mathbf{I}$ & $\mathbf{A}$ & $\mathbf{L}$ & $\mathbf{Y}$ \\
\hline
\end{tabular}
}

https://doi.org/10.19195/0080-3626.63.7

KONRAD K. SZYMAŃSKI

\section{MATERIAŁY DO STANU ZBIORÓW STARYCH DRUKÓW W POLSCE*}

Potrzeba stworzenia informatora o zbiorach starych druków w Polsce. Cele i założenia metodologiczne opracowania. Wykaz instytucji zawierających stare druki z podaniem stanu zbiorów i literatury przedmiotu.

SŁOWA KLUCZOWE: stare druki, biblioteki, muzea, archiwa, informacja naukowa, Polska

Niniejsze materiały zostały przygotowane z inicjatywy Proweniencyjnej Grupy Roboczej powstałej na przełomie września i października 2016 roku podczas międzynarodowej konferencji „Książka dawna i jej właściciele = Early Printed Books and Their Owners". . W działaniach grupy, koordynowanych przez Zakład Narodowy im. Ossolińskich, uczestniczą specjaliści zajmujący się książką dawną i rękopisami z najważniejszych instytucji naukowych i bibliotek w Polsce ${ }^{2}$. Jedną z zaplanowanych inicjatyw grupy na 2018 rok było zestawienie listy bibliotek przechowujących stare druki. Główna idea przyświecająca temu zadaniu

* Autor pragnie w tym miejscu złożyć podziękowania dr Dorocie Sidorowicz-Mulak i dr Agnieszce Franczyk-Cegle, bez których wsparcia i merytorycznych uwag materiały te nigdy nie zostałyby opublikowane.

${ }^{1}$ Zob. A. Wójcik, Sprawozdanie z konferencji „,Książka dawna i jej właściciele”, Wrocław 2016, „Rocznik Biblioteki Narodowej” 47, 2016, s. 233-238; M. Osuch, Konferencja naukowa „Książka dawna i jej właściciele - stan badań, opracowanie, perspektywy”, Wrocław, Zakład Narodowy im. Ossolińskich, 29 IX-1 X 2016 r., „Z Badań nad Książką i Księgozbiorami Historycznymi” 10, 2016, s. 417-421; W. Karlak, Konferencja , Książa dawna i jej właściciele = Early printed books and their owners", 29.09-1.10.2016, Biblioteka Zakladu Narodowego im. Ossolińskich we Wrocławiu, „Roczniki Biblioteczne” 61, 2017, s. 351-355; D. Sidorowicz-Mulak, Sprawozdanie z międzynarodowej konferencji ,Książka dawna i jej właściciele = Early Printed Books and Their Owners”, „Czasopismo Zakładu Narodowego im. Ossolińskich” 2017, z. 28, s. 227-232.

2 Więcej o działaniach i inicjatywach Proweniencyjnej Grupy Roboczej na stronie internetowej Zakładu Narodowego im. Ossolińskich: https://ossolineum.pl/index.php/proweniencyjna-grupa-robocza/ [dostęp: 9.10.2019]. Zob. też M. Kycler, D. Sidorowicz-Mulak, Pierwsze spotkanie Proweniencyjnej Grupy Roboczej (Wrocław, Zakład Narodowy im. Ossolińskich, 7 czerwca 2017 r.), „Przegląd Biblioteczny” 85, 2017, z. 3, s. 358-361.

ROCZNIKI BIBLIOTECZNE ROCZNIKI BIBLIOTECZNE, R. LXIII: 2019

ROK LXIII, 2019

(C) for this edition by CNS 
była prosta - upowszechnienie informacji o instytucjach posiadających w swych zbiorach druki z XV-XVIII wieku, co z kolei umożliwiłoby zupełnie podstawową orientację w tym zakresie dla badaczy dawnej książki w naszym kraju. Działania te miały też stać się asumptem do przeprowadzania dalszych kwerend, ze szczególnym uwzględnieniem badań proweniencyjnych. Prezentowane tutaj materiały, będące pierwszą próbą całościowej rejestracji instytucji ze zbiorami starych druków w Polsce, są poszerzoną wersją wymienionego zestawienia.

W ciągu lat wielokrotnie wskazywano potrzebę powstania tego typu informatora. Widać to doskonale już w postulatach Barbary Bieńkowskiej, która w 1975 roku pisała o istocie prac z zakresu specjalistycznej informacji i dokumentacji zbiorów bibliotecznych ${ }^{3}$. Z kolei w stanowisku Polskiego Towarzystwa Bibliologicznego z 31 maja 1990 roku czytamy między innymi:

Nie ma aktualnej obecnie [...] mapy rozmieszczenia ani polskich zbiorów w kraju i na obczyźnie, ani obcych, które znalazły się na naszej ziemi. [...] Piętrzące się ciągle [...] bariery informacyjne znacznie utrudniają, a często wręcz uniemożliwiają dostęp do ocalałych zasobów książkowych, dotkliwie ograniczając przez to możliwości poznawcze. [...] Szczególnie ważne wydaje się [więc] publikowanie informatorów centralnych i lokalnych o znaczniejszych kolekcjach [...] $]^{4}$.

Krokiem ku realizacji tych wytycznych był niewątpliwie Wykaz bibliotek objętych centralnym katalogiem starych druków opracowany przez Marię Zychowicz w 1995 roku$^{5}$. W tym samym roku opublikowane zostały też artykuły prezentujące wstępne założenia dotyczące Informatora o polskich księgozbiorach historycznych i powstatych na ziemiach polskich do $1950 r^{6}$ planowanego przez Pracownię Dokumentacji Księgozbiorów Historycznych Biblioteki Narodowej7. W zakresie instytucji kościelnych warto tutaj wspomnieć o informatorach wydawanych w latach 2002-2005 w ramach Biblioteki Ośrodka Archiwów, Bibliotek

${ }^{3}$ B. Bieńkowska, Wstęp, „Z Badań nad Polskimi Księgozbiorami Historycznymi” 1975, z. 1, s. 5.

${ }^{4}$ Kronika. Doniosta inicjatywa Polskiego Towarzystwa Bibliologicznego, ,Kwartalnik Historii Nauki i Techniki” 30, 1990, nr 1, s. 652.

5 Wykaz bibliotek objętych centralnym katalogiem starych druków i ich sigla, [w:] M. Zychowicz, Centralny katalog starych druków w Bibliotece Narodowej w Warszawie. Informator, Warszawa 1995, s. 26-30.

6 Zob. m.in. H. Łaskarzewska, Założenia wstępne dotyczace „Informatora o polskich księgozbiorach historycznych i powstatych na ziemiach polskich do 1950 r.”, [w:] Symposia Bibliologica. Dokumentacja księgozbiorów historycznych, wspótpraca krajowa i międzynarodowa. Skutki II wojny światowej dla bibliotek polskich, red. A. Mężyński, H. Łaskarzewska, Warszawa 1995, s. 19-21; H. Łaskarzewska, Problemy metodyczne opracowania „Informatora o polskich księgozbiorach historycznych i powstatych na ziemiach polskich do 1950 r.”, [w:] Symposia Bibliologica..., s. 41-48. Zob. też Informator o bibliotekach i ośrodkach informacji w Polsce na rok 1996/1997, oprac. J. Sadowska, E. Stefańczyk, Warszawa 1997; Informator o bibliotekach i ośrodkach informacji w Polsce na rok 1999, oprac. E. Marburg, E. Stopniak, Warszawa 2000.

7 Obecnie Pracownia Historii Bibliotek i Czytelnictwa, w ramach Instytutu Książki i Czytelnictwa Biblioteki Narodowej. 
i Muzeów Kościelnych KUL ${ }^{8}$. Wraz z rozwojem technologii informatycznych publikowano także artykuły, w których poddawano dyskusji potrzeby digitalizacji centralnego katalogu starych druków ${ }^{9}$, powstawania portali informacyjnych ${ }^{10} \mathrm{czy}$ też opisywano wciąż rozwijające się internetowe bazy danych dotyczące starych druków ${ }^{11}$.

Choć niektóre z tych inicjatyw doszły do fazy ostatecznej realizacji (to jest digitalizacja centralnego katalogu starych druków ${ }^{12}$ ), to jednak do tej pory bardzo trudno o jakikolwiek wykaz samych instytucji posiadających stare druki ${ }^{13}$. Tym bardziej próżno tutaj szukać tak szczegółowych opracowań, jakiego w zakresie zbiorów rękopisów - jeszcze w latach 80. XX wieku — dokonała Danuta Kamolowa ${ }^{14}$. Prócz pełnego zestawienia nazw instytucji i liczebności posiadanych przez nie zbiorów znajdziemy tam również ich historię i charakterystykę oraz szeroką bibliografię przedmiotu. Sporządzenie jednak podobnego przewodnika dotyczącego placówek, w których obecnie znajdują się stare druki, byłoby przedsięwzięciem niezwykle długotrwałym i trudnym do przeprowadzenia pod względem organizacyjnym. Dlatego też, chcąc już teraz udostępnić wszystkim zainteresowanym podstawowe dane o zasobach druków z XV-XVIII wieku w Polsce, zdecydowano się na opracowanie prowizorycznego wykazu, opartego w głównej mierze na danych dostępnych w domenie publicznej oraz drukowanych opracowaniach.

${ }^{8}$ Archiwa Kościoła katolickiego w Polsce. Informator, oprac. M. Dębowska, Kielce 2002; Muzea Kościoła katolickiego w Polsce. Informator, oprac. B. Skrzydlewska, Kielce 2004; oraz Biblioteki Kościoła Katolickiego w Polsce. Informator, oprac. W.W. Żurek, Kielce 2005.

${ }^{9}$ M. Zychowiczowa, Centralny katalog starych druków Biblioteki Narodowej - bez przyszłości? Przyczynek do dyskusji, „Roczniki Biblioteczne” 53, 2009, s. 187-203. Por. wywiad z M. Zychowicz, https://historia.org.pl/2012/02/11/centralny-katalog-starych-drukow-biblioteki-narodowej-w-warszawie-wywiad/ [dostęp: 9.10.2019].

10 Zob. I. Wiencek, Stare druki - o potrzebie portalu informacyjnego i ogólnopolskiej bazy proweniencji, „Z Badań nad Książką i Księgozbiorami Historycznymi” 6, 2012, s. 219-242; M. Kowalewska, Baza proweniencji dawnej ksiązki w Centrum Badawczym Bibliografii Polskiej Estreicherów UJ, „Z Badań nad Książką i Księgozbiorami Historycznymi” 6, 2012, s. 243-245.

11 Zob. R. Frączek, Stare druki w bibliograficznych bazach danych - wybrane aspekty, „Bibliotheca Nostra. Śląski Kwartalnik Naukowy” 2013, nr 4, s. 115-145.

12 Zob. https://polona.pl/card_catalogs/?sort=title\%20asc [dostęp: 10.10.2019]; od marca 2019 roku dostępne są tam zeskanowane karty katalogowe z podziałem na polonika XVI wieku, polonika XVII-XVIII wieku, druki obce XVI-XVIII wieku oraz czasopisma XVIII wieku.

13 Jako o wyjątku w tej kwestii warto wspomnieć o „Alfabetycznym wykazie instytucji posiadających starodruki (według miejscowości)”, dostępnym na stronie Biblioteki Kórnickiej, który wśród 143 instytucji wymienia również 37 placówek zagranicznych. Zob. http://new.bkpan. poznan.pl/wp-content/uploads/2013/09/ckdw-miejsca.pdf [dostęp: 10.10.2019].

14 Zbiory rękopisów w bibliotekach i muzeach w Polsce, oprac. D. Kamolowa przy współudziale K. Muszyńskiej, Warszawa 1988, wyd. 2 popr. i rozszerzone, przy współudziale T. Sieniateckiej, Warszawa 2003 [„Zbiory rękopisów w Polsce”, T. 1] i reedycja, Warszawa 2014; oraz Rękopisy w zbiorach kościelnych, oprac. T. Makowski przy współpr. P. Sapały, Warszawa 2014 [,Zbiory Rękopisów w Polsce”, T. 2]. 
Punktem wyjścia był tutaj wspomniany Wykaz bibliotek objętych centralnym katalogiem starych druków, przygotowany przez Marię Zychowicz. Mimo niewątpliwego nowatorstwa tego rejestru nie można zapominać, że został on wydany niemal ćwierć wieku temu. Zawiera informacje sprzed powodzi z 1997 roku — destrukcyjnej dla wielu zbiorów i niejednokrotnie wymuszającej reorganizacje całych placówek. Od tego czasu wiele instytucji wymienionych w wykazie doznało gruntownych przeobrażeń, co determinowało konieczność weryfikacji i aktualizacji nazw często zupełnie już nowych jednostek. W celu uzupełnienia wykazu Marii Zychowicz, zawierającego odniesienia do 89 bibliotek w Polsce, wykorzystano dostępne publikacje, zbierające nazwy instytucji z cennymi zbiorami na terenie naszego kraju ${ }^{15}$. Należy jednak podkreślić, iż niezwykle wiele precyzyjnych i mimo wszystko o wiele bardziej aktualnych informacji dostarczyły w tym względzie źródła elektroniczne. Internet w największym stopniu umożliwia dzisiaj realizację postulatów PTB. Już wiele instytucji publikuje na stronach internetowych nie tylko podstawowe informacje o swoich zbiorach, ale często również rozbudowane ich charakterystyki wraz z bibliografią ${ }^{16}$ czy nawet odsyłaczami do elektronicznych egzemplarzy poszczególnych druków ${ }^{17}$. Nie brakuje również danych o różnorakich projektach digitalizacyjnych, konserwatorskich czy popularyzatorskich, których efekty stały się dostępne szerokiemu gronu odbiorców właśnie za pośrednictwem Internetu. Niezwykłym ułatwieniem dla badaczy staje się też coraz większa popularność artykułów publikowanych w tak zwanym wolnym dostępie, dzięki czemu także niniejsze opracowanie mogło zostać poszerzone o szczegółowe informacje na temat części opisywanych zbiorów.

$\mathrm{Z}$ powodu coraz łatwiejszego dostępu do informacji o instytucjach posiadających stare druki oraz liczbie i podstawowej charakterystyce tych zbiorów zdecydowano o poszerzeniu niniejszego wykazu również o te informacje. Prócz drukowanych katalogów kolekcji konkretnych instytucji oraz nielicznych artykułów o tych zasobach to właśnie dane zaczerpnięte ze stron internetowych okazały się najważniejszym źródłem informacji tego opracowania. Gdy było to możliwe, w wykazie odnotowano w ramach przypisów podstawową bibliografię (niekiedy wraz z danymi o dysertacjach akademickich) dotyczącą poszczególnych zbiorów.

15 Prócz opracowania D. Kamolowej warto tutaj wspomnieć zwłaszcza o listach instytucji zawartych w Inkunabuly $w$ bibliotekach polskich. Centralny katalog = Incunabula quae in bibliothecis Poloniae asservantur (red. A. Kawecka-Gryczowa, oprac. M. Bohonos, M. Spandowski, E. Szandorowska, T. I-II, Wrocław-Warszawa-Kraków 1970-1993), rejestrach placówek kościelnych zamieszczonych w wymienionych informatorach wydanych w ramach Biblioteki Ośrodka Archiwów, Bibliotek i Muzeów Kościelnych KUL czy też jednostkach muzealnych odnotowanych w M. Sołtysiak, K. Wierzbicka, Muzea w Polsce. Informator, Warszawa 1997.

16 Zob. np. https://www.bn.org.pl/o-nas/zbiory-bn/zbiory/stare-druki; https://ossolineum. pl/index.php/biblioteka-osolineum/dzialy-i-gabinety/dzial-starych-drukow/; https://www.bu.uni. wroc.pl/oddzialy/curie-zbiory-specjalne/oddzial-starych-drukow-zbiory [dostęp: 21.10.2019].

17 Zob. zwłaszcza https://www.dbc.wroc.pl/dlibra/collectiondescription/144 [dostęp: 21.10. 2019].

ROCZNIKI BIBLIOTECZNE

ROK LXIII, 2019

(C) for this edition by CNS 
O ile informacje o największych kolekcjach starodrucznych w kraju są w dużej mierze powszechnie dostępne, o tyle odnośnie do mniejszych placówek (zwłaszcza instytucji kościelnych czy bibliotek publicznych) trudno o jakiekolwiek dane. Toteż w ramach działań Proweniencyjnej Grupy Roboczej, z inicjatywy Marii Kycler (Biblioteka Uniwersytetu Śląskiego), zrodziła się idea, aby nawiązać kontakt z wszystkimi bibliotekami publicznymi w Polsce. W marcu 2018 roku wysłano pisma do 17 bibliotek wojewódzkich w kraju, a za ich pośrednictwem do wszystkich tego typu jednostek w sieci (około 7900 placówek). Instytucje te zostały zapytane o liczbę starych druków w swoich zbiorach oraz o stan ich opracowywania, z uwzględnieniem danych proweniencyjnych. Analizą odpowiedzi z 42 bibliotek (w tym z 37 posiadających stare druki) zajęła się Maria Kycler. Dzięki współpracy w ramach Proweniencyjnej Grupy Roboczej wyniki tej kwerendy zostały uwzględnione w niniejszym opracowaniu.

Na początku 2019 roku na stronie internetowej Zakładu Narodowego im. Ossolińskich (ZNiO) opublikowano materiały zaprezentowane w ramach „III Spotkania Proweniencyjnej Grupy Roboczej” (Wrocław 12 października 2018 roku) ${ }^{18}$, w tym efekty wspomnianej kwerendy Marii Kycler ${ }^{19}$ oraz wciąż rozwijaną, uproszczoną wersję prezentowanego tutaj zestawienia ${ }^{20}$. Dołączono również dwie interaktywne mapki poglądowe ukazujące „Rozmieszczenie instytucji ze zbiorami starych druków w Polsce” oraz „Szacunkowe ilości zbiorów starych druków w poszczególnych miastach Polski"21.

Podobnie jak w kwerendzie przeprowadzonej przez Marię Kycler podczas prac nad niniejszymi materiałami wielokrotnie okazywało się, że termin „stare druki" nie jest jednoznacznie rozumiany, dlatego też wśród opisów niektórych kolekcji starych druków możemy spotkać się z włączaniem do tego zespołu ksiąg wydanych w XIX wieku. Ponadto w wypadku instytucji, które jedynie lakonicznie wzmiankują o posiadaniu w swych zbiorach stare druki, nie możemy być pewni, czy istotnie mowa tutaj o drukach z XV-XVIII wieku. Kolejną trudnością w precyzowaniu i ujednolicaniu wykazu była kwestia różnych jednostek obliczeniowych, w których podawana jest wielkość poszczególnych zbiorów. Liczebność zasobów starano się podawać $\mathrm{w}$ ramach podziału na druki ${ }^{22}$ oraz woluminy ${ }^{23}$. Jednak na tym etapie całkowite ujednolicenie tak różnych i niekiedy nieprzy-

18 Zob. https://ossolineum.pl/index.php/proweniencyjna-grupa-robocza/spotkanie-iii/ [dostęp: 18.10.2019].

19 Zob. https://ossolineum.pl/index.php/proweniencyjna-grupa-robocza/prezentacje-grupy/ [dostęp: 18.10.2019].

20 Zob. https://ossolineum.pl/wp-content/uploads/2019/02/K.-Szymanski-Wykaz-instytucji-ze-zbiorami-starych-druk\%C3\%B3w-w-Polsce.pdf [dostęp: 18.10.2019].

${ }^{21}$ Zob. https://ossolineum.pl/index.php/proweniencyjna-grupa-robocza/rozmieszczenie-instytucji-ze-zbiorami-starych-drukow-w-polsce/ [dostęp: 18.10.2019].

${ }^{22}$ Rozumiane jako ekwiwalent terminów: dzieło, pozycja, jednostka inwentarzowa.

23 Rozumiane jako ekwiwalent terminów: tom, książka, egzemplarz. 
stających do siebie jednostek nie było możliwe. Należy więc mieć na względzie, że przytaczane dane liczbowe pełnią jedynie funkcję orientacyjną i nie powinny służyć do sporządzania jakichkolwiek dalszych wyliczeń, choćby szacunkowych.

Trzeba tu podkreślić, że prezentowane materiały są jedynie scaleniem informacji dostępnych w domenie publicznej i drukowanych publikacjach. Już od wstępnych założeń zainicjowanych w ramach działań Proweniencyjnej Grupy Roboczej niniejsze opracowanie miało służyć zebraniu podstaw do dalszych, pogłębionych kwerend. Drugim celem publikacji niniejszych materiałów, oprócz zaprezentowania danych dotyczących rozmieszczenia i wielkości zbiorów, jest ukazanie stanu i jakości o nich informacji. O tym, że na tym polu pozostaje jeszcze wiele do zrobienia, najlepiej świadczą wskazane wcześniej trudności ze zgromadzeniem danych potrzebnych do sporządzenia tego wykazu. Szczególnie widać tutaj fragmentaryczność i nieaktualizowanie podawanych w domenie publicznej informacji, co dotyczy niekiedy nawet dużych i zasobnych w stare druki bibliotek, muzeów i archiwów. Nie wspominając oczywiście o przypadkach nieudostępniania przez mniejsze placówki jakiejkolwiek informacji na temat własnych zasobów. Można więc opracowanie to traktować jako zachętę dla pracowników insty tucji posiadających stare druki do zintensyfikowania prac nad rejestracją i ich opracowaniem oraz do udostępniania $\mathrm{w}$ domenie publicznej jak najpełniejszych danych o tych kolekcjach. Należy też żywić nadzieję, że prezentowane materiały staną się inspiracją do weryfikacji danych z tego pierwotnego rekonesansu, jak też przyczynkiem do dyskusji nad wypracowywaniem wspólnej metodologii postępowania w kwestii realizacji całościowego i możliwie kompletnego informatora o zasobach starych druków w Polsce.

W niniejszym kształcie wykaz zawiera informacje o $369(381)^{24}$ instytucjach ze zbiorami starych druków w Polsce, zlokalizowanych w 163 (166) miejscowościach $^{25}$. W świetle niniejszego opracowania największą liczbę tworzą tutaj instytucje kościelne (w tym kościoły, klasztory, muzea diecezjalne) i wydziały teologiczne, to jest 147 (158) jednostek. Odnotowano także 113 (114) placówek muzealnych i archiwów państwowych, 53 biblioteki publiczne, 48 bibliotek nauko-

${ }^{24}$ Po przeanalizowaniu danych dotyczących wszystkich 381 instytucji co do 12 z nich (głównie instytucji kościelnych) trudno było jednoznacznie stwierdzić, czy wciąż przechowują zbiory starych druków. Dla orientacji korzystających z wykazu instytucje te zostały umieszczone w tabeli w nawiasach klamrowych.

25 Najwięcej instytucji mieści się w Krakowie - 40 (43) oraz Warszawie — 29 (30). Niniejsze opracowanie najpewniej zawiera dane o bibliotekach uwzględnionych w ramach Centralnego Katalogu Starych Druków Biblioteki Narodowej, określanej liczbowo na około 150 jednostek. Zob. I. Wiencek, op. cit., s. 224; M. Zychowiczowa, op. cit., s. 195. Opracowanie z 2008 roku: Katalogi centralne Biblioteki Narodowej, s. 7, https://docplayer.pl/33560205-Katalogi-centralne-biblioteki-narodowej.html [dostęp: 9.10.2018]. Z kolei w wywiadzie z M. Zychowicz z 11 lutego 2012 roku trzykrotnie podawana jest w tym kontekście liczba 140 bibliotek. Zob. https://historia. org.pl/2012/02/11/centralny-katalog-starych-drukow-biblioteki-narodowej-w-warszawie-wywiad/ [dostęp: 9.10.2018].

ROCZNIKI BIBLIOTECZNE

ROK LXIII, 2019

(C) for this edition by CNS 
wych, 6 bibliotek centralnych oraz 2 biblioteki szkolne. Odnośnie do większości tych miejsc udało się znaleźć, prócz aktualnych danych adresowych — mniej lub bardziej podstawowe - informacje o ich zbiorach starych druków (często z wyodrębnieniem inkunabułów czy poloników).

Gwoli przejrzystości niniejsze zestawienie zostało przygotowane w formie czterokolumnowej tabeli, z podziałem na liczbę porządkową, miejscowość, nazwę i adres instytucji oraz dane o zbiorach. Instytucje zostały usystematyzowane w porządku alfabetycznym, według nazw miejscowości, a w dalszej kolejności według nazw własnych poszczególnych jednostek. W ostatniej kolumnie, dotyczącej zbiorów, starano się zachować strukturę wyróżniającą liczbę starych druków z podziałem na inkunabuły, druki z XVI wieku, druki z XVII wieku oraz druki z XVIII wieku, wraz z podaniem daty aktualizacji tych danych w nawiasach. Gdy nie można było określić liczby interesujących nas zespołów bądź też wiadomości o nich ograniczały się do lakonicznych wzmianek, wprowadzano wyrażenie „,brak szczegółowych danych" wraz z odesłaniem do zdobytych przez nas informacji $\mathrm{w}$ formie przypisu. Jeśli zaś $\mathrm{w}$ dostępnym materiale zetknięto się z różnymi danymi na temat zbiorów, informacje starsze bądź wątpliwe uwzględniano w przypisie, pozostawiając w kolumnie czwartej informacje uznane za najbardziej wiarygodne.

Mimo że lista instytucji z pewnością będzie wymagać dalszej weryfikacji, a liczebność zbiorów pozostaje w dużej mierze bardzo szacunkowa, mam nadzieję, iż wykaz ten będzie w tej chwili użytecznym narzędziem do orientacji o zbiorach starych druków w Polsce. Użytkownik znajdzie tu nie tylko informacje o największych kolekcjach dawnej książki w kraju, lecz także podstawowe dane o dużo mniejszych i niekiedy zapomnianych zbiorach. W trakcie opracowywania niniejszego wykazu trudno było się oprzeć wrażeniu, iż w dzisiejszych czasach stworzenie przewodnika czy informatora o zbiorach starych druków podobnego do tego, jaki opracowała Danuta Kamolowa odnośnie do rękopisów, nie musiałoby być projektem aż tak bardzo odległym. Środowisko bibliotekarzy zajmujących się starymi drukami czeka zatem jeszcze sporo pracy, ale o ileż już dziś łatwiejszej, niż wykonywali ją jeszcze w XIX i XX wieku Karol Estreicher czy Edward Chwalewik.

Tab. 1. Instytucje ze zbiorami starych druków w Polsce

\begin{tabular}{|c|l|l|l|}
\hline Lp. & Miejscowość & \multicolumn{1}{|c|}{ Instytucja } & \multicolumn{1}{c|}{ Stan zbiorów } \\
\hline 1 & Bagno & $\begin{array}{l}\text { Biblioteka Wyższego } \\
\text { Seminarium Duchownego Salwatorianów } \\
\text { Bagno, ul. Ziołowa 51, 55-120 Oborniki Śląskie }\end{array}$ & $\begin{array}{l}\text { 167 druków } \\
(\text { stan na 2013 rok) }\end{array}$ \\
& & \\
\hline
\end{tabular}

26 I. Kiełbasa, 60-lecie Wyższego Seminarium Duchownego Salwatorianów w Bagnie (1953-2013), „Studia Salvatoriana Polonica” 7, 2013, s. 41, http://bazhum.muzhp.pl/media//files/ Studia_Salvatoriana_Polonica/Studia_Salvatoriana_Polonica-r2013-t7/Studia_Salvatoriana_Polonica-r2013-t7-s27-42/Studia_Salvatoriana_Polonica-r2013-t7-s27-42.pdf [dostęp: 18.10.2019]. Jeśli nie podano inaczej, dostęp do źródeł elektronicznych zgodnie ze stanem na październik 2018 roku.

ROCZNIKI BIBLIOTECZNE

ROK LXIII, 2019

(C) for this edition by CNS 


\begin{tabular}{|c|c|c|c|}
\hline 2 & $\begin{array}{l}\text { Biała } \\
\text { Podlaska }\end{array}$ & $\begin{array}{l}\text { I Liceum Ogólnokształcące } \\
\text { im. Józefa Ignacego Kraszewskiego } \\
\text { ul. Józefa Ignacego Kraszewskiego 1, } \\
\text { 21-500 Biała Podlaska }\end{array}$ & $\begin{array}{l}\text { brak szczegółowych } \\
\text { danych }{ }^{27}\end{array}$ \\
\hline 3 & Białystok & $\begin{array}{l}\text { Biblioteka Archidiecezjalnego } \\
\text { Wyższego Seminarium Duchownego } \\
\text { ul. Warszawska 46, 15-077 Białystok }\end{array}$ & $\begin{array}{l}1436 \text { woluminów } \\
(\text { stan na } 2018 \text { rok) }\end{array}$ \\
\hline 4 & Białystok & $\begin{array}{l}\text { Biblioteka Uniwersytecka } \\
\text { im. Jerzego Giedroycia (Zbiory specjalne) } \\
\text { ul. Akademicka 2, 15-267 Białystok }\end{array}$ & $\begin{array}{l}486 \text { woluminów } \\
(\text { stan na } 2017 \text { rok })^{29}\end{array}$ \\
\hline 5 & Białystok & $\begin{array}{l}\text { Książnica Podlaska im. Łukasza Górnickiego } \\
\text { ul. Marii Skłodowskiej-Curie 14A, } \\
\text { 15-097 Białystok }\end{array}$ & 141 woluminów $^{30}$ \\
\hline 6 & Białystok & $\begin{array}{l}\text { Muzeum Podlaskie (Biblioteka) } \\
\text { ul. Świętojańska 17, 15-277 Białystok }\end{array}$ & 19 woluminów ${ }^{31}$ \\
\hline 7 & Biecz & $\begin{array}{l}\text { Biblioteka Muzeum Ziemi Bieckiej } \\
\text { „Starodruki” (jeden z pięciu działów) } \\
\text { ul. Węgierska 1, 38-340 Biecz }\end{array}$ & $\begin{array}{l}\text { brak szczegółowych } \\
\text { danych }{ }^{32}\end{array}$ \\
\hline
\end{tabular}

27 Zob. https://www.dziennikwschodni.pl/lubelskie/informator-o-publicznych-liceach-w-wiekszych-miastach-lubelszczyzny,n,1000021244.html; http://muzeumbiala.pl/historia-muzeum; http://www.kraszak.pl/index.php/biblioteka.

$28 \mathrm{http} / /$ bialystok.wyborcza.pl/bialystok/7,35241,23089091,kontempluj-stronica-po-stronicy-starodruki-on-line.html. W 2005 roku zbiory te miały liczyć 1415 woluminów — zob. Biblioteki Kościoła Katolickiego..., s. 77.

29 https://bg.uwb.edu.pl/?pid=Zbiory_specjalne; http://egzemplarznieobowiazkowy.blogspot. com/2017/03/starodruk-47-ze-zbiorow-biblioteki.html.

30 Dane na podstawie kwerendy M. Kycler. Zob. też http://www.ksiaznicapodlaska.pl/site/ zbiory/staredruki.html. Według https://bia24.pl/kategorie/wiadomosci/ $/ \mathrm{ksi} \% \mathrm{C} 4 \% 85 \% \mathrm{C} 5 \% \mathrm{BCnica}-$ -podlaska-odnowi\%C5\%82a-cenne-starodruki.html stan zbiorów wynosi 138 woluminów.

31 Dane te obejmują wyłącznie stare druki supraskie (z drukarni bazylianów). Zob. http:// muzeum.bialystok.pl/muzeum-podlaskie-w-bialymstoku/biblioteka/; M. Cubrzyńska-Leonarczyk, Oficyna supraska 1695-1803, Warszawa 1993; eadem, Katalog druków supraskich, Warszawa 1996; K. Zimnoch, Znaki proweniencyjne na starych drukach supraskich, „Bibliotekarz Podlaski" 6, 2003, s. 18-35; oraz https://dzieje.pl/kultura-i-sztuka/muzeum-podlaskie-odrestaurowalo-xviii-wieczne-starodruki.

32 Według dostępnych informacji w zbiorach znajdują się inkunabuły i druki z XVI-XVIII wieku — zob. http://mbpgorlice.info/index.php?topic=idzksiazeczko. W 1997 roku zbiory mieściły się zarówno w tak zwanej Kromerówce, jak i w „Domu z Basztą” — zob. M. Sołtysiak, K. Wierzbicka, Muzea w Polsce. Informator, Warszawa 1997, s. 13-15; zob. też http://www.biecz.pl/asp/ pl_start.asp?typ=13\&menu=387\&dzialy=387\&akcja=artykul\&artykul=6818; http://www.muzeum.biecz.pl/o-muzeum-2/biblioteka/; http://www.muzeum.biecz.pl/wystawy/kultura-umyslowa-regionu-bieckiego/; http://www.muzeum.biecz.pl/wystawy/tradycje-aptekarskie-biecza/; http:// www.muzeum.biecz.pl/2016/04/03/informacja-o-realizacji-projektu/; http://www.muzeum.biecz. pl/2018/06/14/dofinansowanie-mkidn/; http://www.trendyradio.pl/pl/aktualnosci/4/gorlice/7268/ remonty-w-muzeum-ziemi-bieckiej. 


\begin{tabular}{|c|c|c|c|}
\hline 8 & Biecz & $\begin{array}{l}\text { Parafia rzymskokatolicka pw. św. Anny } \\
\text { ul. Kazimierza Wielkiego 2, 38-340 Biecz }\end{array}$ & $\begin{array}{l}\text { „ponad } 2000 \text { cen- } \\
\text { nych ksiąg; uni- } \\
\text { katowa biblioteka } \\
\text { z inkunabułami } \\
\text { z XV w."33 }\end{array}$ \\
\hline 9 & Bielsko-Biała & $\begin{array}{l}\text { Książnica Beskidzka } \\
\text { ul. J. Słowackiego 17A, 43-300 Bielsko-Biała }\end{array}$ & 108 woluminów ${ }^{34}$ \\
\hline 10 & Bielsko-Biała & $\begin{array}{l}\text { Muzeum Historyczne } \\
\text { (Biblioteka Fachowa - Zbiory specjalne) } \\
\text { ul. Wzgórze 16, 43-300 Bielsko-Biała }\end{array}$ & $\begin{array}{l}64 \text { druki, w tym } \\
1 \text { inkunabut }^{35}\end{array}$ \\
\hline 11 & Bochnia & $\begin{array}{l}\text { Muzeum im. prof. Stanisława Fischera } \\
\text { Rynek 20, 32-700 Bochnia }\end{array}$ & $\begin{array}{l}\text { brak szczegółowych } \\
\text { danych }{ }^{36}\end{array}$ \\
\hline 12 & Bolesławiec & $\begin{array}{l}\text { Muzeum Ceramiki } \\
\text { (Dział Historii Miasta) } \\
\text { ul. Kutuzowa 14, 59-700 Bolesławiec }\end{array}$ & $\begin{array}{l}\text { brak szczegółowych } \\
\text { danych }{ }^{37}\end{array}$ \\
\hline 13 & $\begin{array}{l}\text { Borki } \\
\text { Wielkie }\end{array}$ & $\begin{array}{l}\text { Klasztor Franciszkanów } \\
\text { ul. Ojca Alarda 3, Borki Wielkie, } \\
\text { 46-300 Olesno }\end{array}$ & $\begin{array}{l}\text { brak szczegółowych } \\
\text { danych }^{38}\end{array}$ \\
\hline 14 & Brzeg & $\begin{array}{l}\text { Muzeum Piastów Śląskich } \\
\text { pl. Zamkowy 1, 49-300 Brzeg }\end{array}$ & $\begin{array}{l}\text { brak szczegółowych } \\
\text { danych }{ }^{39}\end{array}$ \\
\hline 15 & Bydgoszcz & $\begin{array}{l}\text { Biblioteka Główna Uniwersytetu Kazimierza } \\
\text { Wielkiego [wcześniej: Biblioteka Główna Wyż- } \\
\text { szej Szkoły Pedagogicznej] } \\
\text { ul. Karola Szymanowskiego 3, } \\
\text { 85-074 Bydgoszcz }\end{array}$ & $\begin{array}{l}2332 \text { woluminy, } \\
\text { w tym } 15 \text { inkunabu- } \\
\text { lów } 40\end{array}$ \\
\hline
\end{tabular}

33 https://pl.wikipedia.org/wiki/Ko\%C5\%9Bci\%C3\%B3\%C5\%82_i_klasztor_franciszka\% C5\%84ski_w_Bieczu. Zob. też http://www.biecz.pl/asp/pl_start.asp?typ=14\&menu=28\&strona=1; J. Nowak, Druki w języku polskim XVI-XVIII wieku w bibliotece klasztoru oo. Franciszkanów-Reformatów w Bieczu (praca magisterska), Wyższa Szkoła Pedagogiczna, Kraków 1985.

34 Dane na podstawie kwerendy M. Kycler. Pozycje te są dostępne w katalogu elektronicznym pod adresem: https://opac.ksiaznica.bielsko.pl/Opac4.

35 https://muzeum.bielsko.pl/pl/kolekcje/tekst/biblioteka-fachowa; https://katowice.wyborcza.pl/katowice/1,35063,547976.html.

36 W zbiorach znajdują się inkunabuły i druki z XVI-XVIII wieku — zob. http://bochnia.eu/ plmuzealna-akademia-historyczna-starodruki-z-muzealnej-po\%C5\%82ki/; http://www.czasbochenski.pl/stale-rubryki/bochnia-kultura/muzeum-pokaze-swoje-skarby/; zob. też M. Sołtysiak, K. Wierzbicka, op. cit., s. 19.

37 Zob. http://www.muzeum.boleslawiec.net/pl/collections/18.

38 Zob. https://nto.pl/zobacz-skarby-franciszkanow-z-borek-wielkich/ar/4456593.

39 Według M. Sołtysiak i K. Wierzbickiej (op. cit., s. 22) kolekcja ta obejmuje część księgozbioru Piastów brzeskich z XVI-XVII wieku. Zob. też http://zamek.brzeg.pl/biblioteka/; http:// brzeg24.pl/nasze-szkoly/79347-wycieczka-muzeum-piastow-slaskich/.

40 H. Dubowik, Biblioteka Główna Wyższej Szkoły Pedagogicznej w Bydgoszczy, [w:] Rola i funkcje bibliotek Wyższych Szkót Pedagogicznych w Polsce. Materiały z konferencji naukowej zorganizowanej w Rzeszowie w dniach 12-13 września 1988 r., red. Z. Sokół, Rzeszów 1992, 


\begin{tabular}{|c|l|l|l|}
\hline 16 & Bydgoszcz & $\begin{array}{l}\text { Muzeum Okręgowe } \\
\text { im. Leona Wyczółkowskiego } \\
\text { ul. Gdańska 4, 85-006 Bydgoszcz }\end{array}$ & ponad 30 druków ${ }^{41}$ \\
\hline 17 & Bydgoszcz & $\begin{array}{l}\text { Wojewódzka i Miejska Biblioteka Publiczna } \\
\text { im. dr. Witolda Bełzy } \\
\text { Stary Rynek 22-24/ul. Długa 39 (biura), } \\
85-105 \text { Bydgoszcz }\end{array}$ & $\begin{array}{l}\text { 8248 woluminów, } \\
\text { w tym 102 } \\
\text { inkunabuły, około } \\
1 \text { tysiąca druków } \\
\text { z XVI wieku, około } \\
\text { 2 tysiące druków } \\
\text { z XVII wieku } \\
\text { i szacunkowo 5146 } \\
\text { druków z XVIII } \\
\text { wieku (,ponad poło- } \\
\text { wa zasobu”) }\end{array}$ \\
\hline 18 & Bytów & $\begin{array}{l}\text { Muzeum Zachodniokaszubskie } \\
\text { (Dział Artystyczno-Historyczny) } \\
\text { kil. Zamkowa 2, 77-100 Bytów }\end{array}$ & kilkaków ${ }^{43}$ \\
\hline
\end{tabular}

s. 82-83. Zob. też M. Lindenau-Langner, Historia kolekcji starych druków Biblioteki Głównej Wyższej Szkoty Pedagogicznej w Bydgoszczy, „Kronika Bydgoska 1997” 18, 1996, s. 192-196. Według https://pl.wikipedia.org/wiki/Biblioteka_G\%C5\%82\%C3\%B3wna_Uniwersytetu_Kazimierza_Wielkiego) oraz http://biblioteka.ukw.edu.pl/o-bibliotece stan zbiorów wynosi ponad 2 tysiące druków, w tym 18 inkunabułów.

${ }^{41}$ Muzeum przejęło w 2017 roku zbiory Muzeum Farmacji, gdzie znajdowało się ponad 30 (bądź według innych danych 100) starych druków - zob. A. Drygas, W. Ślusarczyk, Biblioteka Muzeum Farmacji apteki „Pod Łabędziem” w Bydgoszczy, „Toruńskie Studia Bibliologiczne” 1, 2013, nr 10, s. 103-106; http://tygodnikbydgoski.pl/wydarzenia/najstarsza-bydgoska-apteka-zlikwidowana-po-164-latach-dzialalnosci; https://pl.wikipedia.org/wiki/Muzeum_Farmacji_w_Bydgoszczy; zob. też B. Wodyński, Jakub Kazimierz Haur ,Skład Abo skarbiec znakomitych sekretów oekonomiey ziemiańskiej”, XVII-wieczny starodruk w Muzeum Farmacji Apteki „Pod Łabędziem” w Bydgoszczy, ,Apothecaria Bydgostiana. Studia z Dziejów Farmacji i Medycyny” 2, 2006, s. 28-29; http://muzeum.bydgoszcz.pl/zbiory/106,0,0,0,Historia-Medycyny-i-Farmacji.

42 J. Matyasik, Skarby Książicy Bydgoskiej. Zabytkowe zbiory Wojewódzkiej i Miejskiej Biblioteki Publicznej im. dr. Witolda Betzy w Bydgoszczy, Bydgoszcz 2018, s. 7; zob. też J. Umiński, Bydgoszcz. Przewodnik, Bydgoszcz 1996; B. Kochańska, Starodruki krakowskie w zbiorach Wojewódzkiej i Miejskiej Biblioteki Publicznej w Bydgoszczy, „Kronika Bydgoska 1998” 19, 1997, s. 382-392; B. Jarosz, B. Mudło, Zabytkowe książki w bibliotece szkolnej, „Poradnik Bibliotekarza" 10, 2003, s. 23-24; J. Matyasik, Polonika XVI-XVII w. ze zbiorów Wojewódzkiej i Miejskiej Biblioteki Publicznej w Bydgoszczy: katalog, Bydgoszcz 2015, http://katalog.nukat.edu.pl/lib/item ?id=chamo:3640016\& theme=nukat. Pod względem proweniencyjnym bardzo cenną część zbiorów starodrucznych stanowią zbiory Biblioteki Bernardynów w Bydgoszczy, od 1907 roku wchodzące w skład Biblioteki Miejskiej - liczą one 1382 woluminy (1557 dzieł), w tym 98 inkunabułów, 758 dzieł z XVI wieku, 583 z XVII wieku oraz 118 z XVIII wieku - zob. F. Mincer, Biblioteka bernardynów bydgoskich i jej ofiarodawcy, „Kronika Bydgoska” 11, 1989, s. 221-234.

${ }_{43}$ M. Sołtysiak, K. Wierzbicka, op. cit., s. 26; http://muzeumbytow.pl/dzial-artystyczno-historyczny/. 


\begin{tabular}{|c|c|c|c|}
\hline 19 & Chełm & $\begin{array}{l}\text { Biblioteka Muzeum Ziemi Chełmskiej } \\
\text { im. Wiktora Ambroziewicza } \\
\text { ul. Lubelska 55, 22-100 Chełm }\end{array}$ & $\begin{array}{l}\text { brak szczegółowych } \\
\text { danych }^{44}\end{array}$ \\
\hline 20 & Chełm & $\begin{array}{l}\text { Chełmska Biblioteka Publiczna } \\
\text { im. Marii Pauliny Orsetti } \\
\text { ul. Partyzantów 40, 22-100 Chełm }\end{array}$ & 21 woluminów 45 \\
\hline 21 & Chojnice & $\begin{array}{l}\text { Muzeum Historyczno-Etnograficzne } \\
\text { im. Juliana Rydzkowskiego } \\
\text { ul. Podmurna 15, 89-620 Chojnice }\end{array}$ & $\begin{array}{l}\text { około } 50 \text { druków } \\
\text { z XVI-XVIII } \\
\text { wieku }^{46}\end{array}$ \\
\hline 22 & Chorzów & $\begin{array}{l}\text { Miejska Biblioteka Publiczna } \\
\text { ul. Jana Sobieskiego 8, } 41-500 \text { Chorzów }\end{array}$ & 14 woluminów ${ }^{47}$ \\
\hline 23 & Chorzów & $\begin{array}{l}\text { Muzeum Miejskie (Biblioteka) } \\
\text { ul. Powstańców 25, 41-500 Chorzów }\end{array}$ & $\begin{array}{l}\text { prawie } 2 \text { tysiące } \\
\text { druków (w tym } \\
\text { inkunabuły) }\end{array}$ \\
\hline 24 & Ciechanowiec & $\begin{array}{l}\text { Muzeum Rolnictwa im ks. Krzysztofa Kluka } \\
\text { (Biblioteka Rolnicza) } \\
\text { ul. Pałacowa 5, 18-230 Ciechanowiec }\end{array}$ & $\begin{array}{l}\text { brak szczegółowych } \\
\text { danych }{ }^{49}\end{array}$ \\
\hline 25 & Cieszyn & $\begin{array}{l}\text { Konwent Zakonu Bonifratrów (Biblioteka) } \\
\text { pl. J. Londzina 1, 43-400 Cieszyn }\end{array}$ & 194 druków 50 \\
\hline 26 & Cieszyn & $\begin{array}{l}\text { Książnica Cieszyńska } \\
\text { ul. Mennicza 46, 43-400 Cieszyn }\end{array}$ & $\begin{array}{l}18500 \text { druków, } \\
\text { w tym } 51 \text { inkunabu- } \\
\text { lów }^{51}\end{array}$ \\
\hline
\end{tabular}

${ }^{44}$ Informacja z działalności Muzeum Ziemi Chetmskiej im. W. Ambroziewicza w Chetmie za 2014 rok, Chełm 2014, s. 6, https://docplayer.pl/5545563-Informacja-z-dzialalnosci-muzeum-ziemi-chelmskiej-im-w-ambroziewicza-w-chelmie-za-2014-rok.html; zob. też http://www.muzeum.chelm.pl/?pl_historii,633; http://mzch.pl/?pl_konserwacja-starodrukow,440.

45 Dane na podstawie kwerendy M. Kycler.

46 W tym 28 druków z kolekcji Albina Makowskiego — zob. https://weekendfm.pl/?n=60114; https://chojnicemuzeum.pl/index.php?kolekcja-historyczno-regionalna-albina-makowskiego,24; http://www.chojnice.com/wiadomosci/teksty/Cenny-starodruk-trafil-do-muzeum/16449; zob. też A. Czapczyk, Ku pamięci. Kolekcja starych druków w zbiorach biblioteki Muzeum Historyczno-Etnograficznego im. J. Rydzkowskiego w Chojnicach, „Baszta” 2016, nr 13, https://chojnicemuzeum.pl/mobile.php?baszta-nr-13,180; M. Sołtysiak, K. Wierzbicka, op. cit., s. 29.

47 Dane na podstawie kwerendy M. Kycler.

48 R. Skoczek-Kulpa, Katalog starych druków Muzeum w Chorzowie, Chorzów 1998. Według https://pl.wikipedia.org/wiki/Muzeum_w_Chorzowie zbiory starych druków liczą 2 tysiące woluminów, w tym polonika i silesiaka. Zob. też M. Sołtysiak, K. Wierzbicka, op. cit., s. 31.

49 Wśród zbiorów starodrucznych ,znajduje się m.in. komplet dzieł patrona muzeum Księdza Krzysztofa Kluka" — https://www.muzeumrolnictwa.pl/muzeum/dzialy/biblioteka.

50 Projekt, ochrona i konserwacja cieszyńskiego dziedzictwa piśmienniczego, tekst K. Szelong, Cieszyn 2010, s. 8; https://bonifratrzy.pl/klasztor-cieszyn/historia-klasztoru/.

51 http://kc-cieszyn.pl/index.php/content,239/; https://pl.wikipedia.org/wiki/Ksi\%C4\%85\% C5\%BCnica_Cieszy\%C5\%84ska. 


\begin{tabular}{|c|c|c|c|}
\hline 27 & Cieszyn & $\begin{array}{l}\text { Muzeum Śląska Cieszyńskiego } \\
\text { (Biblioteka Naukowa) } \\
\text { ul. T. Regera 6, 43-400 Cieszyn } \\
\text { (wejście od ul. Srebrnej 1A) }\end{array}$ & $\begin{array}{l}370 \text { druków, w tym } \\
21 \text { inkunabułów }^{52}\end{array}$ \\
\hline 28 & Cieszyn & $\begin{array}{l}\text { Parafia Ewangelicko-Augsburska } \\
\text { (zbiory w Bibliotece i Archiwum } \\
\text { im. Tschammera - Muzeum Protestantyzmu) } \\
\text { pl. Kościelny 6, 43-400 Cieszyn }\end{array}$ & $\begin{array}{l}\text { prawie } 5 \text { tysięcy } \\
\text { druków, w tym } \\
5 \text { inkunabułów } \\
53\end{array}$ \\
\hline 29 & Czarnolas & $\begin{array}{l}\text { Muzeum Jana Kochanowskiego (Oddział Mu- } \\
\text { zeum im. Jacka Malczewskiego w Radomiu) } \\
\text { 26-720 Policzna }\end{array}$ & $\begin{array}{l}\text { brak szczegółowych } \\
\text { danych }^{54}\end{array}$ \\
\hline 30 & Czerna & $\begin{array}{l}\text { Archiwum klasztoru Karmelitów Bosych } \\
\text { Czerna 79, 32-065 Krzeszowice }\end{array}$ & $\begin{array}{l}3270 \text { druków } \\
(\text { stan na } 2008 \text { rok })^{55}\end{array}$ \\
\hline 31 & Częstochowa & $\begin{array}{l}\text { Biblioteka Jasnogórska } \\
\text { (Biblioteka Starodruków/,Stara”) } \\
\text { ul. o. A. Kordeckiego 2, 42-225 Częstochowa }\end{array}$ & $\begin{array}{l}13300 \text { druków } \\
\text { oraz } 103 \text { woluminy } \\
\text { inkunabułów (stan } \\
\text { na } 2013 \text { rok }^{56} \text { ) }\end{array}$ \\
\hline
\end{tabular}

52 Projekt, ochrona i konserwacja..., s. 9; http://muzeumcieszyn.pl/index.php?option=com_ content\&task= view\&id=160\&Itemid=140.

${ }^{53}$ Projekt, ochrona i konserwacja..., s. 7; Parafia Ewangelicko-Augsburska w Cieszynie. Biblioteka i Archiwum im. Tschammera Muzeum Protestantyzmu. Informator, Cieszyn 2010, s. 4; http://www.muzeum.cieszyn.org.pl/index.php/zasoby-cyfrowe/zasoby-biblioteczne.

54 Zob. M. Sołtysiak, K. Wierzbicka, op. cit., s. 34; http://www.krajoznawcy.info.pl/muzeum-calkiem-z-niczego-8053; http://zsp.ciepielow.pl/cms/artykul-499-wycieczka_do_muzeum_ jana_kochanowskiego_w_czarnolesie_html.

${ }^{55}$ B. Pawełczyk, Biblioteki klasztorne na przykładzie archiwum i bibliotek Klasztoru Karmelitów Bosych w Czernej, „Fides: Biuletyn Bibliotek Kościelnych” 1-2, 2008, s. 80-82; zob. też J. Długosz, Biblioteka klasztoru karmelitów bosych w Czernej, „Archiwa, Biblioteki i Muzea Kościelne" 11, 1965, s. 109-117.

56 Biblioteki Kościoła Katolickiego..., s. 208; https://turystyka.wp.pl/jasna-gora-jedyne-takie-miejsce-w-polsce-6044396231709313a; https://pl.wikipedia.org/wiki/Jasna_G\%C3\%B3ra; http://www.jasnagora.com/nastronach_opracowanie.php?ID=27\&Strona=3; zob. też http://jasnagora.pl/pl/o-sanktuarium/biblioteki/biblioteka-jasnogorska/; B. Polkowska, Konserwatorska ocena stanu zachowania druków zwartych z XVIII wieku pochodzacych z klasztornej oficyny drukarskiej na Jasnej Górze w Częstochowie (praca magisterska), Uniwersytet Śląski, Katowice 1999; W. Szotek, Konserwatorska ocena fragmentu zbioru Biblioteki Jasnogórskiej obejmujaca druki XVI-wiecznych oficyn z Frankfurtu nad Menem (praca magisterska), Uniwersytet Śląski, Katowice 1999; M. Szymura, Druki oficyn jezuickich z XVII i XVIII wieku w zbiorach klasztornej Biblioteki Jasnogórskiej (praca magisterska), Uniwersytet Śląski, Katowice 1999; A. Warzecha, Analiza stanu zachowania druków wydawanych Ex Officina Plantiniana pochodzacych z kolekcji Biblioteki Jasnogórskiej (praca magisterska), Uniwersytet Śląski, Katowice 1999; A. Wierzbicka, Analiza stanu zachowania druków wydanych w Kolonii do roku 1560 zgromadzonych w Bibliotece Jasnogórskiej Ojców Paulinów w Częstochowie (praca magisterska), Uniwersytet Śląski, Katowice 1999; D. Rajkowski, Druki biblijne w kolekcji Biblioteki Jasnogórskiej w Częstochowie w roku jubileuszu wydania Biblii Jakuba Wujka (praca magisterska), Uniwersytet Śląski, Katowice 2000; W. Ryszka, Bibliografia i konserwatorska ocena inkunabułów i starodruków z Biblioteki Jasnogór- 
skiej w Częstochowie (praca magisterska), Uniwersytet Śląski, Katowice 2000; K. Sosna, „Druki z Oficyny Piotrkowczyków w zbiorach Biblioteki Jasnogórskiej w Częstochowie - konserwatorska ocena stanu zachowania kolekcji" (praca magisterska), Uniwersytet Śląski, Katowice 2000; M. Zaremba-Szurma, Konserwatorska ocena stanu zachowania druków kolońskich z drugiej połowy XVI wieku z Biblioteki Jasnogórskiej w Częstochowie (praca magisterska), Uniwersytet Śląski, Katowice 2000; A. Hajkiewicz, Bibliografia dziet oraz sygnetów z weneckich oficyn drukarskich XVI wieku w kolekcji Biblioteki Jasnogórskiej w Częstochowie (praca magisterska), Uniwersytet Śląski, Katowice 2001; K. Kudlińska, Kolekcja druków z XVI i XVII wieku z oficyn augsburskich w Bibliotece Jasnogórskiej w Częstochowie. Analiza typograficzna i ocena konserwatorska (praca magisterska), Uniwersytet Śląski, Katowice 2001; K. Mosz, Starodruki z oficyn Strasburga w zbiorach Biblioteki Jasnogórskiej w Częstochowie. Analiza bibliograficzna i typograficzna kolekcji (praca magisterska), Uniwersytet Śląski, Katowice 2001; M. Noras, Druki z oficyn kolońskich z początku XVII wieku w zbiorach Biblioteki Jasnogórskiej. Bibliograficzna i typograficzna ocena kolekcji (praca magisterska), Uniwersytet Śląski, Katowice 2001; M. Szewczyk, Druki z oficyn pijarskich w Bibliotece Jasnogórskiej w Częstochowie. Bibliograficzna i konserwatorska ocena kolekcji (praca magisterska), Uniwersytet Śląski, Katowice 2001; G. Uherek, Kolekcja druków z XVI i XVII wieku z oficyn mogunckich w Bibliotece Jasnogórskiej w Częstochowie. Analiza typograficzna i ocena konserwatorska (praca magisterska), Uniwersytet Śląski, Katowice 2001; A. Karolow, Inkunabuly biblioteki Ojców Paulinów na Jasnej Górze w Częstochowie (praca licencjacka), Uniwersytet Mikołaja Kopernika, Toruń 2003; M. Kretek, Kolekcja druków z XV do XVII wieku z oficyn norymberskich w Bibliotece Jasnogórskiej w Częstochowie. Analiza typograficzna i ocena konserwatorska (praca magisterska), Uniwersytet Śląski, Katowice 2003; A. Krałze, Zarys dziejów i organizacji zasobu starodruków biblioteki oo. paulinów w Częstochowie (praca magisterska), Uniwersytet Jana Kochanowskiego, Kielce 2003; E. Kwiecińska, Inkunabuły weneckie w zasobach Biblioteki Jasnogórskiej. Ocena typograficzna i konserwatorska kolekcji (praca magisterska), Uniwersytet Śląski, Katowice 2003; M. Michalczyk, Konserwatorska ocena stanu zachowania najstarszych druków z paryskich oficyn wydawniczych w zasobach Biblioteki Jasnogórskiej (praca magisterska), Uniwersytet Śląski, Katowice 2003; R. Michałkiewicz, Starodruki z oficyn Strasburga w zasobach Biblioteki Jasnogórskiej. Konserwatorska ocena stanu zachowania (praca magisterska), Uniwersytet Śląski, Katowice 2003; B. Mrowiec, Inkunabuty z oficyn Lipska w zasobach Biblioteki Jasnogórskiej. Ocena typograficzna i konserwatorska kolekcji (praca magisterska), Uniwersytet Śląski, Katowice 2003; U. Stepaniak, Inkunabuty z oficyn drukarskich Norymbergii w zasobach Biblioteki Jasnogórskiej. Konserwatorska ocena stanu zachowania kolekcji (praca magisterska), Uniwersytet Śląski, Katowice 2003; B. Szymczak, Najstarsze druki lyońskie w zasobach Biblioteki Jasnogórskiej. Analiza typograficzna i konserwatorska kolekcji (praca magisterska), Uniwersytet Śląski, Katowice 2003; R. Dudek, Analiza topograficzna najstarszych druków biblijnych w kolekcji Biblioteki Jasnogórskiej w Częstochowie (praca magisterska), Uniwersytet Śląski, Katowice 2004; M. Holona, Drukarze krakowscy z XVI wieku z kolekcji Biblioteki Jasnogórskiej w Częstochowie (praca magisterska), Uniwersytet Śląski, Katowice 2004; M. Świderska, Analiza bibliologiczna i typograficzna druków francuskich z XVI wieku z kolekcji Biblioteki Jasnogórskiej w Częstochowie (praca magisterska), Uniwersytet Śląski, Katowice 2004; I. Bolek, Dzieła z poznańskich oficyn drukarskich w zasobach Biblioteki Jasnogórskiej w Częstochowie (praca magisterska), Uniwersytet Śląski, Katowice 2005; A. Farciak, Dzieła z krakowskiej Drukarni Łazarzowej w kolekcji Biblioteki Jasnogórskiej w Częstochowie (praca magisterska), Uniwersytet Śląski, Katowice 2005; M. Świerkot, Druki z oficyn gdańskich w kolekcji zabytkowej Biblioteki Jasnogórskiej w Częstochowie (praca magisterska), Uniwersytet Śląski, Katowice 2005; J. John, Druki polskie w kolekcji zabytkowej Biblioteki Jasnogórskiej (praca magisterska), Uniwersytet Śląski, Katowice 2007; M. Krzyżowski, Polskie druki homiletyczne o Bibliotece Jasnogórskiej. Próby katalogowego uporządkowania kolekcji (praca licencjacka), Uniwersytet Ślą-

\section{ROCZNIKI BIBLIOTECZNE}

ROK LXIII, 2019

(C) for this edition by CNS 


\begin{tabular}{|c|l|l|l|}
\hline 32 & Częstochowa & $\begin{array}{l}\text { Biblioteka Publiczna } \\
\text { im. dr. Władysława Biegańskiego } \\
\text { al. Najświętszej Maryi Panny 22, } \\
\text { 42-200 Częstochowa }\end{array}$ & 118 woluminów $^{57}$ \\
\hline 33 & Częstochowa & $\begin{array}{l}\text { Biblioteka Wyższego Seminarium Duchownego } \\
\text { Archidiecezji Częstochowskiej } \\
\text { i Wyższego Instytutu Teologicznego } \\
\text { [wcześniej: Biblioteka Diecezjalna] } \\
\text { ul. św. Barbary 41, 42-200 Częstochowa }\end{array}$ & $\begin{array}{l}\text { około 40 druków } \\
\text { (stan na 2015 rok) }\end{array}$ \\
\hline 34 & Częstochowa & $\begin{array}{l}\text { Jasnogórski Instytut Maryjny } \\
\text { (Jasnogórska Biblioteka Maryjna) } \\
\text { ul. Kordeckiego 2, 42-225 Częstochowa }\end{array}$ & $\begin{array}{l}\text { około 50 wolumi- } \\
\text { nów }\end{array}$ \\
\hline 35 & Częstochowa & $\begin{array}{l}\text { Muzeum Archidiecezji Częstochowskiej } \\
\text { ul. św. Barbary 41, 42-200 Częstochowa }\end{array}$ & $\begin{array}{l}\text { brak szczegółowych } \\
\text { danych }\end{array}$ \\
\hline 36 & Człuchów & $\begin{array}{l}\text { Muzeum Regionalne (Biblioteka) } \\
\text { ul. Kościelna 8, 77-300 Człuchów }\end{array}$ & $\begin{array}{l}\text { brak szczegółowych } \\
\text { danych } 61\end{array}$ \\
\hline
\end{tabular}

ski, Katowice 2009; J. Długosz, Prototypografia z Wenecji w kolekcji Biblioteki Jasnogórskiej ${ }_{w}$ Częstochowie. Indeks typograficzny druków zwartych (praca magisterska), Uniwersytet Śląski, Katowice 2011; M. Krzyżowski, Prototypografia ze Strasburga w kolekcji Biblioteki Jasnogórskiej w Częstochowie. Indeks typograficzny druków zwartych (praca magisterska), Uniwersytet Śląski, Katowice 2011; A. Michalska, Prototypografia z Bazylei w kolekcji Biblioteki Jasnogórskiej Częstochowie. Indeks typograficzny druków zwartych (praca magisterska), Uniwersytet Śląski, Katowice 2011; A. Mirek, Prototypografia z Lipska w kolekcji Biblioteki Jasnogórskiej w Częstochowie. Indeks typograficzny druków zwartych (praca magisterska), Uniwersytet Śląski, Katowice 2011; B. Pochaba, Prototypografia z Kolonii w kolekcji Biblioteki Jasnogórskiej w Częstochowie. Indeks typograficzny druków zwartych (praca magisterska), Uniwersytet Śląski, Katowice 2011. Por. informacje na podstawie https://podroze.onet.pl/polska/slaskie/jasna-gora-zwiedzanie-klasztoru-historia-co-zobaczyc/10n6hxk; https://podroze.onet.pl/polska/slaskie/jasna-gora-zwiedzanie-klasztoru-historia-co-zobaczyc/10n6hxk.

57 Dane na podstawie kwerendy M. Kycler. Według http://czestochowa.wyborcza.pl/czest ochowa/7,150461,22745296,skarby-biblioteki-w-alejach-sa-tu-ksiazki-ktore-oglada-sie.html stan zbiorów starodrucznych wynosi ponad 160 druków.

58 A. Olczyk, Biblioteka Wyższego Seminarium Duchownego Archidiecezji Częstochowskiej oraz Wyższego Instytutu Teologicznego w Częstochowie, „Veritati et Caritati” 4, 2015, s. 354, http:// wydawnictwo.wit-czestochowa.pl/Editor/assets/tom\%204/347-358.pdf.

59 http://bm.jasnagora.pl/pl/o-bibliotece/; zob. też K. Rospondek, Biblioteka Maryjna w Częstochowie (praca magisterska), Uniwersytet Łódzki, Łódź 2001.

60 Zob. Muzea Kościoła katolickiego w Polsce. Informator, oprac. B. Skrzydlewska, Kielce 2004, s. 33; http://www.muzeakosc.czest.pl/starodruki.php.

${ }^{61}$ M. Sołtysiak, K. Wierzbicka, op. cit., s. 37; http://www.muzeumczluchow.pl/pl/o-muzeum/biblioteka. 


\begin{tabular}{|c|c|c|c|}
\hline 37 & Darłowo & $\begin{array}{l}\text { Zamek Książąt Pomorskich (Muzeum) } \\
\text { ul. Zamkowa 4, 76-150 Darłowo }\end{array}$ & $\begin{array}{l}157 \text { druków, w tym } \\
10 \text { druków z XVI } \\
\text { wieku, } 34 \text { druki } \\
\text { z XVII wieku oraz } \\
113 \text { druków z XVI- } \\
\text { II wieku (stan na } \\
2012 \text { rok) }\end{array}$ \\
\hline 38 & Dobra & $\begin{array}{l}\text { Muzeum Parafialne } \\
\text { (filia Muzuem Diecezjalnego w Tarnowie) } \\
\text { 34-642 Dobra k. Limanowej }\end{array}$ & $\begin{array}{l}\text { brak szczegółowych } \\
\text { danych }^{63}\end{array}$ \\
\hline 39 & Drohiczyn & $\begin{array}{l}\text { Archiwum i Muzeum Diecezjalne } \\
\text { ul. Kościelna 10, 17-312 Drohiczyn } \\
\text { Muzeum Diecezjalne im. Jana Pawła II } \\
\text { ul. Kraszewskiego 4, 17-312 Drohiczyn }\end{array}$ & $\begin{array}{l}293 \text { druki, w tym } \\
1 \text { inkunabuł, } \\
5 \text { druków z XVI } \\
\text { wieku, } 33 \text { druki } \\
\text { z XVII wieku, } \\
220 \text { druków z XVIII } \\
\text { wieku, } 34 \text { druki z lat } \\
\text { 1801-1811 (prawdo- } \\
\text { podobnie cyrylickie) } \\
\text { (stan na } 2004 \text { rok) }^{64}\end{array}$ \\
\hline 40 & Dukla & $\begin{array}{l}\text { Pałac w Dukli (Muzeum Historyczne) } \\
\text { Trakt Węgierski 5, 38-450 Dukla }\end{array}$ & $\begin{array}{l}\text { brak szczegółowych } \\
\text { danych }\end{array}$ \\
\hline
\end{tabular}

${ }^{62}$ M. Kurzyńska, Kolekcje starych druków w bibliotekach muzealnych obszaru woj. zachodniopomorskiego - historia i wspótczesność. Zarys problematyki [Prezentacja z konferencji „Zbiory specjalne w bibliotekach polskich - problematyka badawcza i organizacyjna. Ogólnopolska konferencja naukowa”, Książnica Pomorska w Szczecinie 14-15.11.2013], slajd 37-43, https://muzeum. szczecin.pl/images/pliki/biblioteka/Zbiory-specjalne-w-bibliotekach-polskich-wersja-z-pieczatkami.pdf; oraz eadem, Druki pomorskie w kolekcji starych druków Biblioteki Muzeum Narodowego w Szczecinie na tle zasobów bibliotek muzeów Pomorza Zachodniego [Prezentacja z konferencji „Piśmiennictwo na Pomorzu Zachodnim do końca XVIII wieku", Uniwersytet Szczeciński 8-9.12.2014], slajd 5-8, https://muzeum.szczecin.pl/images/pliki/biblioteka/Druki-pomorskie-w-BMNS.pdf. Zbiory obejmują polonika i pomeranika z zakresu historii, teologii, sztuki oraz prawa i administracji.

63 Muzea Kościoła katolickiego..., s. 38; http://muzeum.diecezja.tarnow.pl/dobra/.

${ }^{64}$ E. Borowski, Ogólna informacja o zasobie Archiwum Diecezjalnego w Drohiczynie, [w:] Źródła do dziejów regionu, Siedlce 2002 (uzupełniona wersja artykułu z 2004 roku), s. 8, http://drohiczynska.pl/wp-content/uploads/2017/01/Ogolna_informacja_o_zasobie_Archiwum_ Diecezjalnego_w_Drohiczynie.pdf; Archiwa Kościoła Katolickiego w Polsce. Informator, oprac. M. Dębowska, Kielce 2002, s. 33; zob. też http://www.bu.kul.pl/art_10438.html.

65 Zob. http://cojestgrane24.wyborcza.pl/cjg24/Dukla/1,43,102248,Wystawa-stala--Z-dziejow-Dukli-i-dukielskiego-zesp.html; http://www.archiwalne.radio.rzeszow.pl/informacje/41589/spektakl-i-wystawa-w-muzeum-historycznym-w-dukli; http://www.powiat.krosno.pl/aktualnoci/1126-na-theatrum-w-dukli; https://www.google.com/url?sa $=\mathrm{t} \& \mathrm{rct}=\mathrm{j} \& \mathrm{q}=\& \mathrm{esrc}=\mathrm{s} \&$ source=web\& $\mathrm{cd}=17$ $\&$ cad $=$ rja\&uact $=8 \&$ ved $=2$ ahUKEwjAsvfRuPbdAhXCyaQKHZ-8Bn04ChAWMAZ6BAgDEAI\& url=http\%3A\%2F\%2Fwww.brzostek.pl\%2Fasp\%2Fpliki\%2Faktualnosci\%2Fkarnet_turystyczny_ glowne_atrakcje_turystyczne.pdf\&usg=AOvVaw1FKK9Ws68LHjHciFOlP1MC.

\section{ROCZNIKI BIBLIOTECZNE}

ROK LXIII, 2019

(C) for this edition by CNS 


\begin{tabular}{|c|c|c|c|}
\hline 41 & Elbląg & $\begin{array}{l}\text { Archiwum Diecezjalne } \\
\text { ul. św. Ducha 11, 82-300 Elbląg }\end{array}$ & $\begin{array}{l}\text { brak szczegółowych } \\
\text { danych }\end{array}$ \\
\hline 42 & Elbląg & $\begin{array}{l}\text { Biblioteka Elbląska im. Cypriana Norwida } \\
\text { ul. św. Ducha 25, 82-300 Elbląg }\end{array}$ & 9022 woluminy $^{67}$ \\
\hline 43 & Elbląg & $\begin{array}{l}\text { Muzeum Archeologiczno-Historyczne } \\
\text { bulwar Zygmunta Augusta II, 82-300 Elbląg }\end{array}$ & $\begin{array}{l}\text { co najmniej } 7 \text { wolu- } \\
\text { minów } 68\end{array}$ \\
\hline 44 & Ełk & $\begin{array}{l}\text { Biblioteka Wyższego Seminarium Duchownego } \\
\text { Diecezji Ełckiej } \\
\text { ul. Kościuszki 9, 19-300 Ełk }\end{array}$ & 5 woluminów 69 \\
\hline 45 & Frombork & $\begin{array}{l}\text { Muzeum Mikołaja Kopernika } \\
\text { ul. Katedralna 8, 14-530 Frombork }\end{array}$ & $\begin{array}{l}800 \text { druków, w tym } \\
6 \text { inkunabułów }^{70}\end{array}$ \\
\hline 46 & Gdańsk & $\begin{array}{l}\text { Archiwum Państwowe (Biblioteka) } \\
\text { ul. Wałowa 5, 80-858 Gdańsk }\end{array}$ & $\begin{array}{l}\text { brak szczegółowych } \\
\text { danych }^{71}\end{array}$ \\
\hline
\end{tabular}

${ }^{66}$ Zob. https://www.info.elblag.pl/5,8778,Historia-na-kartach.html; Archiwa Kościoła Katolickiego..., s. 35 .

${ }^{67}$ Dane na podstawie kwerendy M. Kycler. Na obecny zasób starych druków złożyły się głównie zbiory zwrócone w 2001 roku przez Bibliotekę UMK w Toruniu w liczbie 8657 woluminów - zob. https://www.bu.umk.pl/stare_druki; zob. też http://www.zkpis.umk.pl/?w-bibliotece-elblaskiej-im.-c.-norwida,162. W ramach $E B C$ zamieszczono 4449 starych druków — http:// dlibra.bibliotekaelblaska.pl/dlibra/collectiondescription?dirids=48. Według Zbiorów zabytkowych Biblioteki Elblaskiej. Informatora (oprac. A. Kowalczyk, Elbląg 2006, s. 11, http://dlibra.bibliotekaelblaska.pl/dlibra/docmetadata?id=28902) w 2006 roku w bibliotece znajdowało się 8938 woluminów starych druków, w tym 69 woluminów inkunabułów. Zob. też J. Lassota, Zarys dziejów Biblioteki Elbląskiej (1601-1945), „Rocznik Elbląski” 1, 1961, s. 97-120; K. Greczycho, Depozyty zbiorów Biblioteki Miejskiej w Elblagu, [w:] Biblioteka Elblaska - przeszłość i teraźniejszość = Elblag Library - past and present, red. P. Derlukiewicz, Elbląg 2001, s. 39-46; J. Sekulski, Biblioteka gimnazjum elblaskiego w XVII-XVIII w., [w:] Biblioteka Elblaska 1601-2001. Materiaty z sesji naukowej zorganizowanej z okazji 400-lecia Biblioteki Elblaskiej, Elblag, 23 XI 2001 r., red. W. Długokęcki, Elbląg 2001, s. 17-42; idem, Elblag i jego biblioteka, [w:] Biblioteka Elbląska przeszłość i teraźniejszość..., s. 5-29; L. Słodownik, Działalność Biblioteki Miejskiej w Elblagu w XIX i XX wieku (do 1945 roku), [w:] Biblioteka Elblaska 1601-2001..., s. 53-72; M. Strutyńska, Stare druki Biblioteki Elblaskiej, [w:] Zbiory zabytkowe Biblioteki Elblaskiej. Materiaty z sesji naukowej zorganizowanej w Bibliotece Elblaskiej 24 listopada 2006 r., Elbląg 2006, s. 19-31, http:// www.kpbc.ukw.edu.pl/dlibra/plain-content?id=27564.

68 M. Sołtysiak, K. Wierzbicka, op. cit., s. 44; https://www.portel.pl/kultura/zakonczenie-projektu-rozwoj-elblaskiej-biblioteki-cyfrowej-etap-3/87105; http://www.museo.pl/content/view/241/207/; https://stratyzabytkow.nimoz.pl/aktual/kradzieze-polskich-muzeach-latach-1965-1996/.

69 http://biblioteka.wsd.elk.pl/zbiory.htm; http://biblioteka.wsd.elk.pl/starodr.htm. W 2005 roku zbiory te miały liczyć 3 woluminy — zob. Biblioteki Kościoła Katolickiego..., s. 84.

70 http://frombork.art.pl/pl/biblioteka-muzeum/; http://frombork.art.pl/pl/inkunabuly/. Zob. też Katalog starodruków Muzeum Mikołaja Kopernika we Fromborku, oprac. H. Szkop, http:// frombork.art.pl/pl/katalog-starodrukow-k/; http://frombork.art.pl/pl/starodruki-l-w/; http://frombork.art.pl/pl/indeks/; M. Sołtysiak, K. Wierzbicka, op. cit., s. 44.

${ }^{71}$ Stare druki stanowią część zbiorów specjalnych, liczących około 600 jednostek — zob. https://www.gdansk.ap.gov.pl/pl/top/biblioteka. 


\begin{tabular}{|c|c|c|c|}
\hline 47 & Gdańsk & $\begin{array}{l}\text { Biblioteka Gdańska Polskiej Akademii Nauk } \\
\text { [wcześniej: Biblioteka Polskiej Akademii Nauk } \\
\text { (dawna Miejska)] } \\
\text { ul. Wałowa 15, 80-858 Gdańsk }\end{array}$ & $\begin{array}{l}\text { ponad } 64 \text { tysiące } \\
\text { woluminów, w tym } \\
755 \text { inkunabułów } \\
(\text { stan na } 2012 \text { rok) })^{72}\end{array}$ \\
\hline 48 & Gdańsk & $\begin{array}{l}\text { Biblioteka Główna Uniwersytetu Gdańskiego } \\
\text { (Zbiory Specjalne) } \\
\text { ul. Wita Stwosza 53, 80-308 Gdańsk }\end{array}$ & 907 woluminów ${ }^{73}$ \\
\hline 49 & Gdańsk & $\begin{array}{l}\text { Biblioteka Politechniki Gdańskiej } \\
\text { (Pracownia Zbiorów Zabytkowych } \\
\text { i Starych Druków) } \\
\text { ul. Gabriela Narutowicza 11/12, 80-233 Gdańsk }\end{array}$ & $\begin{array}{l}\text { „659 woluminów } \\
\text { i druków, z czego } \\
90 \text { to czasopisma” } \\
\text { (opisane jako „Naj- } \\
\text { starsze zbiory Poli- } \\
\text { techniki Gdańskiej”) } \\
\text { (stan na } 2017 \text { rok) }\end{array}$ \\
\hline
\end{tabular}

72 http://www.bgpan.gda.pl/zbiory.php; B. Gryzio, Muzeum czarnej sztuki. Katalog inkunabułów PAN Biblioteki Gdańskiej, Gdańsk 2012; zob. też H. Jędrzejowska, M. Pelczarowa, Katalog inkunabułów Biblioteki Miejskiej w Gdańsku, Gdańsk 1954; Katalog inkunabułów Biblioteki Gdańskiej Polskiej Akademii Nauk, cz. 2. Uzupetnienia i dodatki, oprac. H. Jędrzejowska, M. Pelczarowa, Gdańsk 1967; A. Jędrzejowska, H. Jędrzejowska, M. Pelczarowa, Polonica XVI do XVIII wieku nie znane Bibliografii Estreichera ze zbiorów Biblioteki Gdańskiej, z. 1, Gdańsk 1968; A. Jędrzejowska, M. Pelczarowa, A. Siemiginowska, Polonica XVI do XVIII wieku nie znane Bibliografii Estreichera ze zbiorów Biblioteki Gdańskiej, z. 2, Gdańsk-Poznań 1969; L. Pszczółkowska, A. Siemiginowska, Polonica XVI do XVIII wieku nie znane Bibliografii Estreichera ze zbiorów Biblioteki Gdańskiej, z. 3, Wrocław-Warszawa-Kraków-Gdańsk 1980.

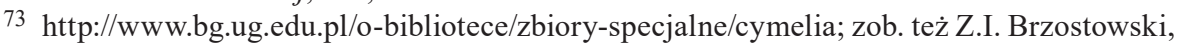
Proweniencja inkunabułów i starodruków Józefa Flawiusza w Bibliotece Gdańskiej PAN. Wydania greckie i łacińskie, „Rocznik Gdański” 61, 2001, nr 2, s. 179-184.

${ }^{74} \mathrm{http}$ ///ustrobiblioteki.pl/2017/04/najpilniej-strzezone-ksiazki-gdansku-dzien-leza-ognioodpornych-polkach/; zob. też Wikipedia, https://pl.wikipedia.org/wiki/Biblioteka_Politechniki_ Gda\%C5\%84skiej: „Dopiero rok 2000 przywrócił Politechnice część tego cennego księgozbioru. W czerwcu tegoż roku Senat Miasta Bremy zwrócił Politechnice 850 starodruków, rękopisów i innych materiałów ze zbiorów TPwG. Obecnie wchodzą one w skład najcenniejszej kolekcji Zbiorów Zabytkowych Biblioteki. Część z nich dostępna jest w formie zdigitalizowanej w Pomorskiej Bibliotece Cyfrowej:

Wystawa starych druków PB, 26-28.04.2017 r. (https://pg.edu.pl/biblioteka-pg/aktualnosci/-/ asset_publisher/T5ivcSIolwc6/content/wystawa-starych-drukow?redirect=https\%3A\%2F\%2Fpg. edu.pl\%2Fbiblioteka-pg\%2Faktualnosci\%3Fp_p_id\%3D101_INSTANCE_T5ivcSIolwc6\%26p_p_ lifecycle\%3D0\%26p_p_state\%3Dnormal\%26p_p_mode $\% 3$ Dview $\% 26 \mathrm{p} \_p \_c o l \_i d \% 3 D c o l u m n-$ $-1 \% 26 \mathrm{p} \_\mathrm{p} \_$col_count $\left.\% 3 \mathrm{D} 1\right)$

Konserwacja i digitalizacja starych druków PG [24 woluminy] (https://pg.edu.pl/biblioteka -pg/aktualnosci/-/asset_publisher/T5ivcSIolwc6/content/konserwacja-i-digitalizacja-starych-drukow?redirect=https $\% 3 \mathrm{~A} \% 2 \mathrm{~F} \% 2 \mathrm{Fpg}$.edu.pl $\% 2$ Fbiblioteka-pg\%2Faktualnosci $\% 3 \mathrm{Fp} \_\mathrm{p}$ _id $\%$ 3D101_INSTANCE_T5ivcSIolwc6\%26p_p_lifecycle $\% 3 \mathrm{D} 0 \% 26 \mathrm{p} \_\mathrm{p}$ _state $\% 3 \mathrm{Dnormal} \%$ $26 p \_p \_m o d e \% 3 D v \bar{i} w \% 26 p \_p \_c o l \_i d \% 3$ Dcolumn-1\%26p_p_col_count $\% 3 D 1 \% 26$ _ 101_INSTANCE_T5ivcSIolwc6_advancedSearch\%3Dfalse $\% 26$ _101_INSTANCE_T5ivc SIolwc6_keywords\%3D\%26_101_INSTANCE_T5ivcSIolwc6_delta\%3D100\%26p_r_p_ 564233524_resetCur\%3Dfalse\%26_101_INSTANCE_T5ivcSIolwc6_cur\%3D2\%26_101_IN-

\section{ROCZNIKI BIBLIOTECZNE}

ROK LXIII, 2019

(C) for this edition by CNS 


\begin{tabular}{|c|c|c|c|}
\hline 50 & Gdańsk & $\begin{array}{l}\text { Gdańskie Seminarium Duchowne } \\
\text { (Biblioteka im. ks. prof. Kazimierza } \\
\text { Kloskowskiego) } \\
\text { ul. Biskupa Edmunda Nowickiego 3, } \\
\text { 80-330 Gdańsk }\end{array}$ & 461 druków $^{75}$ \\
\hline 51 & Gdańsk & $\begin{array}{l}\text { Wojewódzka i Miejska Biblioteka Publiczna } \\
\text { im. Josepha Conrada Korzeniowskiego } \\
\text { Targ Rakowy 5/6, 80-806 Gdańsk }\end{array}$ & $\begin{array}{l}1 \text { druk } \\
\text { (w } 2 \text { woluminach) })^{76}\end{array}$ \\
\hline 52 & Głogów & $\begin{array}{l}\text { Muzeum Archeologiczno-Historyczne } \\
\text { ul. Brama Brzostowska 1, 67-200 Głogów }\end{array}$ & $\begin{array}{l}\text { brak szczegółowych } \\
\text { danych }{ }^{77}\end{array}$ \\
\hline 53 & Głubczyce & $\begin{array}{l}\text { Klasztor Franciszkanów pw. św. Idziego } \\
\text { i św. Bernardyna (Biblioteka Starodruków) } \\
\text { ul. Zakonna 6, 48-100 Głubczyce }\end{array}$ & $\begin{array}{l}\text { brak szczegółowych } \\
\text { danych }\end{array}$ \\
\hline 54 & Głubczyce & $\begin{array}{l}\text { Miejska i Gminna Biblioteka Publiczna } \\
\text { ul. Rynek 1, 48-100 Głubczyce }\end{array}$ & $\begin{array}{l}\text { co najmniej } 42 \text { druki, } \\
\text { w tym co najmniej } \\
1 \text { inkunabul79 }\end{array}$ \\
\hline 55 & Gniezno & $\begin{array}{l}\text { Biblioteka Katedralna } \\
\text { (Dział Archiwum Archidiecezjalnego) } \\
\text { ul. Kolegiaty 2, 62-200 Gniezno }\end{array}$ & $\begin{array}{l}\text { około } 40 \text { tysięcy } \\
\text { woluminów, w tym } \\
\text { około } 1100 \text { inkuna- } \\
\text { bułów } 80\end{array}$ \\
\hline 56 & Gniezno & $\begin{array}{l}\text { Biblioteka Prowincjalna Franciszkanów } \\
\text { ul. Franciszkańska 12, 62-200 Gniezno }\end{array}$ & $\begin{array}{l}1072 \text { druków } \\
\text { (w } 1007 \text { wolu- } \\
\text { minów), w tym } \\
378 \text { druków } \\
\text { z XVI wieku }\end{array}$ \\
\hline
\end{tabular}

STANCE_T5ivcSIolwc6_orderByColumn1\%3DmodifiedDate\%26_101_INSTANCE_T5ivcSIolwc6_andŌperator\%3Dtrue)".

${ }^{75}$ https://www.trojmiasto.pl/Biblioteka-Seminarium-Duchownego-o38604.html. W 2005 roku zbiory te miały liczyć 441 woluminów — zob. Biblioteki Kościoła Katolickiego..., s. 86.

76 Dane na podstawie kwerendy M. Kycler. W 2016 roku została wykonana konserwacja tych druków.

77 Biblioteka ma w swoich zbiorach stare druki ,z najstarszych głogowskich drukarni m.in. Schweickardt'a i Christiana F. Günthera" — http://www.muzeum.glogow.pl/p,102, hi.

${ }^{78}$ Zob. http://www.zkpis.umk.pl/?w-bibliotece-klasztoru-ojcow-franciszkanow-w-glubczycach,81; GMINA GŁUBCZYCE. Gminny program opieki nad zabytkami dla Gminy Gtubczyce na lata 2014-2017, oprac. W. Wrona-Gaj, Głubczyce 2013, s. 22, https://www.prawomiejscowe.pl/api/ file/GetZipxAttachment/146/311284/preview.

79 Informacje na podstawie https://www.sbc.org.pl/dlibra/results?action=AdvancedSearchA ction \&type $=-3 \& \mathrm{p}=0 \&$ val1 $=$ Localization:g\%C5\%82ubczyce \&val2=Date:14000101 18000101\&va $13=$ Type:starodruk.

${ }^{80}$ Według http://www.archiwum.archidiecezja.pl/pl/biblioteka/charakterystyka-zasobu. html zbiory te zawierają 600 jednostek z kategorii poloników z XVI wieku. Zob. też L. Formanowicz, Katalog druków polskich XVI w. Biblioteki Kapitulnej w Gnieznie, Poznań 1930.

81 Z. Joskowski, Stare druki z księgozbiorów klasztornych w zbiorach Biblioteki Prowincjalnej Franciszkanów w Gnieźnie. Apendyks do katalogu starych druków, [w:] Hereditas Monasteriorum, 


\begin{tabular}{|c|c|c|c|}
\hline 57 & Gorlice & $\begin{array}{l}\text { Muzeum w Centrum Diecezjalnym przy cerkwi } \\
\text { prawosławnej pw. św. Trójcy (jeden z działów } \\
\text { Ośrodka Kultury Prawosławnej Elpis) } \\
\text { ul. św. Maksyma 2, 38-300 Gorlice }\end{array}$ & $\begin{array}{l}\text { co najmniej } 65 \text { wolu- } \\
\text { minów }^{82}\end{array}$ \\
\hline 58 & Gorlice & $\begin{array}{l}\text { Muzeum Regionalne Polskiego Towarzystwa } \\
\text { Turystyczno-Krajoznawczego } \\
\text { im. Ignacego Łukasiewicza } \\
\text { ul. Wąska 7-9, 38-300 Gorlice }\end{array}$ & $\begin{array}{l}\text { brak szczegółowych } \\
\text { danych }^{83}\end{array}$ \\
\hline 59 & $\begin{array}{l}\text { Gorzów } \\
\text { Wielkopolski }\end{array}$ & $\begin{array}{l}\text { Archiwum Państwowe (Biblioteka) } \\
\text { ul. Ignacego Mościckiego 7, } \\
\text { 66-400 Gorzów Wielkopolski }\end{array}$ & $\begin{array}{l}\text { brak szczegółowych } \\
\text { danych }\end{array}$ \\
\hline 60 & $\begin{array}{l}\text { Gorzów } \\
\text { Wielkopolski }\end{array}$ & $\begin{array}{l}\text { Wojewódzka i Miejska Biblioteka Publiczna } \\
\text { im. Zbigniewa Herberta } \\
\text { (Dział Zbiorów Specjalnych) } \\
\text { ul. Sikorskiego 107, } \\
\text { 66-400 Gorzów Wielkopolski }\end{array}$ & 279 woluminów 85 \\
\hline 61 & Gostyń & $\begin{array}{l}\text { Kongregacja Oratorium św. Filipa Neri } \\
\text { Święta Góra-Głogówko 1, 63-800 Gostyń }\end{array}$ & $\begin{array}{l}\text { brak szczegółowych } \\
\text { danych }\end{array}$ \\
\hline
\end{tabular}

T. 5, [b.m.w.] 2014, s. 303-327, https://docplayer.pl/10905492-Stare-druki-z-ksiegozbiorow-klasztornych-w-zbiorach-biblioteki-prowincjalnej-franciszkanow-w-gnieznie-apendyks-do-katalogu-starych-drukow.html; idem, Katalog starych druków Biblioteki Franciszkanów w Gnieźnie, Gniezno-Banino 2010, s. 300. Według Biblioteki Kościoła Katolickiego... (s. 192) w 2005 roku zbiory te liczyły 910 woluminów starych druków.

82 Według R. Dubec (Cyrylickie starodruki cerkiewne XVII-XVIII w. ze zbiorów instytucji kościelnych i parafii prawosławnych woj. małopolskiego. Katalog, Gorlice 2010, s. 3) kolekcja starodruków cerkiewnych z XVII-XVIII wieku zawiera ponad 30 egzemplarzy ksiąg liturgicznych i paraliturgicznych. Sam katalog liczy 47 druków, w tym 28 z XVII wieku. W katalogu internetowym (http://www.okp-elpis.pl/museum,starodruk,0,0,Katalog_starodruk\%C3\%B3w.html) można znaleźć zaś informację o 65 drukach.

${ }^{83}$ Zob. http://www.beskid-niski.pl/index.php?pos=/obiekty\&ID=371. Wiadomo, że w zbiorze znajdują się De origine et rebus gestis polonorum Marcina Kromera, wydane w Bazylei w 1555 roku, porządek sądowy spraw miejskich prawa magdeburskiego z 1616 roku oraz księgi prawa magdeburskiego wydane w Zamościu w 1601 i 1602 roku. Zob. też https://dnidziedzictwa. $\mathrm{pl} /$ muzeum-regionalne-pttk-w-gorlicach/.

${ }^{84} \mathrm{http}: / /$ www.gorzow.ap.gov.pl/p,66,edukacja.

85 Dane na podstawie kwerendy M. Kycler; zob. też https://www.wimbp.gorzow.pl/kategoria/ dzialy-wimbp/dzial-zbiorow-specjalnych/.

${ }^{86}$ Zob. Katalog biblioteki Kongregacji św. Filipa Neri w Gostyniu z 1881 roku (rękopis), http://www.wbc.poznan.pl/dlibra/docmetadata?id=347516\&from=publication. 


\begin{tabular}{|c|c|c|c|}
\hline 62 & Gościkowo & $\begin{array}{l}\text { Biblioteka Wyższego Seminarium Duchownego } \\
\text { Diecezji Zielonogórsko-Gorzowskiej } \\
\text { w Gościkowie-Paradyżu } \\
\text { Gościkowo 3, 66-200 Świebodzin }\end{array}$ & $\begin{array}{l}1328 \text { druków w } 1265 \\
\text { woluminach, w tym } \\
14 \text { inkunabułów } \\
\text { w } 17 \text { woluminach, } \\
218 \text { druków z XVI } \\
\text { wieku, } 288 \text { druków } \\
\text { z XVII wieku, } 808 \\
\text { druków z XVIII } \\
\text { wieku (stan na } 2001 \\
\text { rok) }\end{array}$ \\
\hline 63 & $\begin{array}{l}\text { Góra } \\
\text { św. Anny }\end{array}$ & $\begin{array}{l}\text { Sanktuarium św. Anny } \\
\text { ul. Klasztorna 6, 47-154 Góra św. Anny }\end{array}$ & $\begin{array}{l}\text { brak szczegółowych } \\
\text { danych }\end{array}$ \\
\hline 64 & $\begin{array}{l}\text { Górka } \\
\text { Klasztorna }\end{array}$ & $\begin{array}{l}\text { Biblioteka Sanktuarium Maryjnego } \\
\text { Rataje 48, 89-310 Łobżenica }\end{array}$ & $\begin{array}{l}\text { brak szczegółowych } \\
\text { danych }\end{array}$ \\
\hline 65 & Grudziądz & $\begin{array}{l}\text { Biblioteka Miejska im. Wiktora Kulerskiego } \\
\text { ul. Legionów 28, 86-300 Grudziądz }\end{array}$ & 268 druków $^{90}$ \\
\hline 66 & Grudziądz & $\begin{array}{l}\text { Muzeum im. ks. dr. Władysława Łęgi } \\
\text { (Dział historii) } \\
\text { ul. Wodna 3/5, 86-300 Grudziądz }\end{array}$ & $\begin{array}{l}\text { brak szczegółowych } \\
\text { danych }^{91}\end{array}$ \\
\hline 67 & Grybów & $\begin{array}{l}\text { Muzeum Parafialne } \\
\text { (oddział Muzeum Diecezjalnego w Tarnowie) } \\
\text { ul. Kościelna 3, 33-330 Grybów }\end{array}$ & $\begin{array}{l}\text { brak szczegółowych } \\
\text { danych }^{92}\end{array}$ \\
\hline
\end{tabular}

87 J. Stoś, Starodruki Paradyża: katalog starodruków seminaryjnej biblioteki w Paradyżu, Warszawa 2001, s. 16. Dalsza bibliografia i charakterystyka zbiorów zob. idem, Katalog starodruków biblioteki seminaryjnej w Paradyżu, „Archiwa, Biblioteki i Muzea Kościelne” 75, 2001, s. 261-396; idem, Siedemnastowieczne druki okolicznościowe w zbiorach Biblioteki Paradyskiej, Szczecin 2002; A. Pliszczyński, Księgi XVI-wieczne w Bibliotece-Pracowni starodruków Wyższego Seminarium Duchownego w Paradyżu, Poznań 2003. Według T. Błaszczyka (Druki XVI-wieczne w Bibliotece Wyższego Seminarium Duchownego Diecezji Zielonogórsko-Gorzowskiej w Gościkowie-Paradyżu, „Perspectiva. Legnickie Studia Teologiczno-Historyczne” 6, 2007, nr 1, s. 8-9, http://perspectiva.pl/pdf/p10/ks_blaszczyk.pdf) w 1989 roku biblioteka posiadała 1320 woluminów starych druków, w tym 210 druków z XVI wieku. Z kolei według Bibliotek Kościoła Katolickiego... (s. 134) w 2005 roku w zbiorach tych miały się znajdować 142 woluminy starych druków, w tym 12 woluminów inkunabułów.

${ }^{88}$ Zob.http://dziedzictwo.ekai.pl/@@gora_sw_anny_klasztor; http://radio.opole.pl/100,256 662,ksiazki-z-biblioteki-klasztoru-na-gorze-sw-anny- \&s=1\&si=1\&sp=1.

${ }^{89}$ Zob. H. Połczyńska, Starodruki i druki XIX-wieczne w Bibliotece Sanktuarium Maryjnego w Górce Klasztornej (praca magisterska), Uniwersytet Mikołaja Kopernika, Toruń 2006.

${ }^{90}$ Dane na podstawie kwerendy M. Kycler. Według http://www.biblioteka.grudziadz.pl/index.php?m=m_el\&id=215 w tak zwanym księgozbiorze niemieckim biblioteki znajduje się 239 woluminów starych druków.

91 Zob. http://muzeum.grudziadz.pl/strona-113-digitalizacja.html.

92 Zob. https://pl.wikipedia.org/wiki/Muzeum_Parafialne_w_Grybowie. 


\begin{tabular}{|c|c|c|c|}
\hline 68 & Imbramowice & $\begin{array}{l}\text { Klasztor Norbertanek Sanktuarium } \\
\text { Męki Pańskiej } \\
\text { Imbramowice 105, 32-353 Imbramowice }\end{array}$ & $\begin{array}{l}650 \text { druków } \\
(\text { stan na } 1976 \text { rok })^{93}\end{array}$ \\
\hline 69 & Inowrocław & $\begin{array}{l}\text { Biblioteka Miejska im. Jana Kasprowicza } \\
\text { ul. Kilińskiego 16, 88-100 Inowrocław }\end{array}$ & 530 druków $^{94}$ \\
\hline 70 & Inowrocław & $\begin{array}{l}\text { I Liceum Ogólnokształcące } \\
\text { im. Jana Kasprowicza (Biblioteka) } \\
\text { ul. } 3 \text { maja 11/13, 88-100 Inowrocław }\end{array}$ & $\begin{array}{l}\text { brak szczegółowych } \\
\text { danych }\end{array}$ \\
\hline 71 & Jarosław & $\begin{array}{l}\text { Klasztor pw. św. Trójcy Ojców Franciszkanów } \\
\text { Reformatów (Biblioteka) } \\
\text { ul. Jana Pawła II 16, 37-500 Jarosław }\end{array}$ & $\begin{array}{l}\text { około } 5 \text { tysięcy dru- } \\
\text { ków (stan na } 2013 \\
\text { rok) }\end{array}$ \\
\hline 72 & Jarosław & $\begin{array}{l}\text { Muzeum Kamienica Orsettich (Biblioteka) } \\
\text { Rynek 4, 37-500 Jarosław }\end{array}$ & $\begin{array}{l}132 \text { woluminy (stan } \\
\text { na } 2005 \text { rok })^{97}\end{array}$ \\
\hline 73 & Jasło & $\begin{array}{l}\text { Muzeum Regionalne } \\
\text { ul. Stanisława Kadyiego 11, 38-200 Jasło }\end{array}$ & $\begin{array}{l}138 \text { woluminów, } \\
\text { w tym } 1 \text { inkunabu1 }\end{array}$ \\
\hline 74 & Jelenia Góra & $\begin{array}{l}\text { Książnica Karkonoska (Jeleniogórskie Centrum } \\
\text { Informacji i Edukacji Regionalnej) [wcześniej: } \\
\text { Wojewódzka Biblioteka Publiczna] } \\
\text { ul. Bankowa 27, 58-500 Jelenia Góra }\end{array}$ & 1 wolumin ${ }^{99}$ \\
\hline
\end{tabular}

${ }^{93}$ R. Nir, Rękopisy liturgiczne Biblioteki PP. Norbertanek w Imbramowicach, ,Ruch Biblijny i Liturgiczny" 29, 1976, nr 1, s. 48, http://cejsh.icm.edu.pl/cejsh/element/bwmeta1.element. ojs-doi-10_21906_rbl_3336/c/3336-3422.pdf; zob. też M. Mól, Zbiory klasztoru ss. Norbertanek w Imbramowicach (praca magisterska), Uniwersytet Śląski, Katowice 2008.

94 Dane na podstawie kwerendy M. Kycler. Według https://www.jan-kasprowicz.bmino.pl/ czytelnia-biblioteki-glownej.html biblioteka od 1948 roku posiada 532 stare druki z XVIII wieku, pochodzące z księgozbioru rodu Hahn z Postenden w Kurlandii.

95 http://www.kasprowicz.az.pl/biblioteka.php; https://pl.wikipedia.org/wiki/I_Liceum_Og\% C3\%B3lnokszta\%C5\%82c\%C4\%85ce_im._Jana_Kasprowicza_w_Inowroc\%C5\%82awiu. O historycznych zbiorach inowrocławskich zob. też J. Starnawski, Dwa inwentarze biblioteki franciszkanów inowrocławskich z lat 1669 i 1702, [w:] idem, Ludzie książki, Częstochowa 2000, s. 33-60.

96 Biblioteki Kościoła Katolickiego..., s. 214-215; http://www.jaroslawska.pl/artykul/ 9691,Gocinni-Franciszkanie. Zob. A. Sroka, Biblioteka starodruków Klasztoru Franciszkanów Reformatów w Jarosławiu, „Rocznik Stowarzyszenia Miłośników Jarosławia” 12, 1986-1993, s. 139144, http://www.pbc.rzeszow.pl/dlibra/docmetadata?id=10701.

97 http://www.jaroslaw.pl/nasze-wydawnictwa/id17_11_10,80-lat-Muzeum-w-Jaroslawiu-cz.-II.html?print=1. Zob. też http://www.muzeum-jaroslaw.pl/biblioteka.php: „Na szczególną uwagę wśród starodruków zasługują księgi wydrukowane w Jarosławiu w drukarni Jana Szeligi na początku XVII wieku, a najstarszym naszym starodrukiem jest leksykon prawniczy wydany w Paryżu w 1534 roku".

$98 \mathrm{http://cojestgrane24.wyborcza.pl/cjg24/Jaslo/1,43,101716,-Kolekcja-starodrukow----stala-}$ -wystawa.html; https://www.jaslo4u.pl/jasielskie-muzeum-regionalne-zaprezentowalo-kolekcje-starodr-newsy-jaslo-16491. Zob. też https://muzeumjaslo.pl/zbiory/starodruki/; M. Sołtysiak, K. Wierzbicka, op. cit., s. 67.

99 Dane na podstawie kwerendy M. Kycler. Zob. też https://biblioteka.jelenia-gora.pl/strona-glowna/o-nas/regulamin/.

\section{ROCZNIKI BIBLIOTECZNE}

ROK LXIII, 2019

(C) for this edition by CNS 


\begin{tabular}{|c|c|c|c|}
\hline 75 & Jelenia Góra & $\begin{array}{l}\text { Muzeum Karkonoskie } \\
\text { ul. Jana Matejki 28, 58-500 Jelenia Góra }\end{array}$ & $\begin{array}{l}\text { co najmniej } 18 \text { dru- } \\
\text { ków } 100\end{array}$ \\
\hline 76 & Jędrzejów & $\begin{array}{l}\text { Państwowe Muzeum im. Przypkowskich } \\
\text { pl. Kościuszki 7/8, 28-300 Jędrzejów }\end{array}$ & $\begin{array}{l}\text { około } 600 \text { wolumi- } \\
\text { nów, w tym kilka } \\
\text { inkunabułów (stan } \\
\text { na } 2006 \text { rok) }\end{array}$ \\
\hline 77 & Kalisz & $\begin{array}{l}\text { Archiwum Państwowe w Kaliszu } \\
\text { (Biblioteka) } \\
\text { ul. Poznańska 207, 62-800 Kalisz }\end{array}$ & $\begin{array}{l}\text { brak szczegółowych } \\
\text { danych }^{102}\end{array}$ \\
\hline 78 & Kalisz & $\begin{array}{l}\text { Biblioteka Wyższego Seminarium Duchownego } \\
\text { Diecezji Kaliskiej } \\
\text { ul. Złota 144, 62-800 Kalisz }\end{array}$ & 15 woluminów ${ }^{103}$ \\
\hline 79 & Kalisz & $\begin{array}{l}\text { Miejska Biblioteka Publiczna } \\
\text { im. Adama Asnyka } \\
\text { ul. Legionów 66, } 62-800 \text { Kalisz }\end{array}$ & $\begin{array}{l}245 \text { druków (stan na } \\
2018 \text { rok) }\end{array}$ \\
\hline 80 & Kalisz & $\begin{array}{l}\text { Publiczna Biblioteka Pedagogiczna } \\
\text { (Książnica Pedagogiczna) } \\
\text { ul. Południowa 62, 62-800 Kalisz }\end{array}$ & $\begin{array}{l}\text { brak szczegółowych } \\
\text { danych }{ }^{105}\end{array}$ \\
\hline 81 & $\begin{array}{l}\text { Kalwaria } \\
\text { Zebrzydow- } \\
\text { ska }\end{array}$ & $\begin{array}{l}\text { Biblioteka Wyższego Seminarium Duchownego } \\
\text { Ojców Bernardynów } \\
\text { ul. Bernardyńska 25, } \\
\text { 34-130 Kalwaria Zebrzydowska }\end{array}$ & $\begin{array}{l}\text { około } 4030 \text { wolumi- } \\
\text { nów, w tym } 30 \text { wolu- } \\
\text { minów inkunabułów } \\
\text { (w depozycie Biblio- } \\
\text { teki Bernardynów } \\
\text { w Krakowie) } \\
(\text { stan na } 2005 \text { rok) }\end{array}$ \\
\hline
\end{tabular}

100 https://www.muzeumkarkonoskie.pl/zakonczenia-projektu-konserwacja-wzornika-szklarskiego-oraz-starodrukow-ze-zbiorow-muzeum-karkonoskiego-w-jeleniej-gorze/.

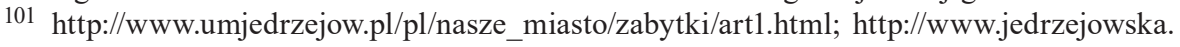
net/dziela-kopernika-heweliusza-newtona-zyja-jakby-drugim-zyciem/; M. Sołtysiak, K. Wierzbicka, op. cit., s. 70 .

102 http://www.archiwum.kalisz.pl/pliki/ksiegozbior.pdf.

103 Biblioteki Kościoła Katolickiego..., s. 89.

104 https://www.kalisz.pl/dla-mieszkanca/aktualnosci/kolejna-perla-w-bibliotece,4133; zob. też https://wkaliszu.pl/8053776/KSIAZKI_Kolejne_unikalne_starodruki_w_kaliskiej_bibliotece. html; M. Sobczak-Waliś, Calisiana w kolekcji starodruków Miejskiej Biblioteki Publicznej im. Adama Asnyka w Kaliszu, [w:] Miscellanea archiwalne, biblioteczne i muzealne, red. B. Celer, Kalisz 2016, s. 157-189.

105 Zob. http://www.kp.kalisz.pl/1/katalogi/zbiory/starodruki.html; http://www.kp.kalisz.pl/1/ obibliotece/charakterystyka.html.

106 Biblioteki Kościoła Katolickiego..., s. 185. Według https://opoka.org.pl/biblioteka/T/ trans/pielgrzymka2002/sanktuarium.html w bibliotece znajdują się liczne stare druki, w tym 18 inkunabułów polskich. 


\begin{tabular}{|c|c|c|c|}
\hline 82 & $\begin{array}{l}\text { Kamieniec } \\
\text { Ząbkowicki }\end{array}$ & $\begin{array}{l}\text { Archiwum Państwowe } \\
\text { (Oddział Archiwum Państwowego } \\
\text { we Wrocławiu) } \\
\text { pl. Kościelny 4, 57-230 Kamieniec Ząbkowicki }\end{array}$ & $\begin{array}{l}\text { brak szczegółowych } \\
\text { danych }\end{array}$ \\
\hline 83 & Katowice & $\begin{array}{l}\text { Biblioteka Parafialna OO. Franciszkanów } \\
\text { ul. Związkowa 20, 40-760 Katowice-Panewniki }\end{array}$ & 65 druków 108 \\
\hline 84 & Katowice & $\begin{array}{l}\text { Biblioteka Śląska } \\
\text { (Czytelnia Zbiorów Specjalnych) } \\
\text { pl. Rady Europy 1, 40-021 Katowice }\end{array}$ & $\begin{array}{l}\text { około } 27 \text { tysięcy } \\
\text { woluminów, w tym } \\
56 \text { woluminów inku- } \\
\text { nabułów } 109\end{array}$ \\
\hline
\end{tabular}

107 https://www.dhpolska.pl/firma/aktualnosci/archiwum-panstwowe-z-zabezpieczeniami-dh.html.

108 https://parafia.panewniki.pl/dom-parafialny/biblioteka/historia-biblioteki/. Według Bibliotek Kościoła Katolickiego... (s. 144) w 2005 roku zbiory specjalnie jeszcze nie były skatalogowane. Archiwa Kościoła Katolickiego... (s. 143) podają natomiast, że w 2002 roku w ramach zasobu Archiwum Prowincji OO. Franciszkanów, przy ul. Panewnickiej 76, wydzielano „starodruki” jako osobną kategorię zbiorów.

109 Dane na podstawie kwerendy M. Kycler. Według http://www.bs.katowice.pl/pl/dla_czytelnikow/czytelnie_i_wypozyczalnia/czytelnia_zbiorow_specjalnych; http://www.bs.katowice.pl/ $\mathrm{pl} /$ kolekcje/zbiory_specjalne zbiory starych druków to prawie 28 tysięcy woluminów Bibliografia: http://www.bs.katowice.pl/pdf/dla_czytelnikow/stare_druki.pdf. Zob. też J. Berger-Mayerowa, Broszury i ulotki z XVII-XIX w. w Księgozbiorze Szembeków, „Biuletyn Informacyjny Biblioteki Śląskiej” 2, 1957, s. 59-63; J. Mayer, Starodruki z oficyn w Antwerpii - w szczególności z drukarni Plantin-Moretów - w zbiorach Biblioteki Ślaskiej, „Biuletyn Informacyjny Biblioteki Śląskiej” 1, 1969, nr 4, s. 74-82; idem, Dzieła z pieczatkami Załuskich w księgozbiorze Biblioteki Śląskiej, „Biuletyn Informacyjny Biblioteki Śląskiej” 1, 1970, nr 4, s. 113-129; idem, O śląskim sinologu Janie Wyplerze i jego księgozbiorze w Bibliotece Śląskiej, „Biuletyn Informacyjny Biblioteki Śląskiej" 16, 1971, s. 60-71; idem, Dzieła z księgozbioru Jakuba Trembeckiego i rodziny w Bibliotece Ślaskiej w Katowicach, „Roczniki Biblioteczne” 1, 1972, nr 2, s. 79-111; J. Berger-Mayerowa, Nie znane Estreicherowi „Polonica” i ,Silesiaca” w starodrukach Biblioteki Ślaskiej, Seria 1-2, Katowice 1961-1968; M. Kaganiec, Księgozbiór Kreckwitzów w zbiorach Biblioteki Śląskiej, „Książnica Śląska” 23, 1985/1987, s. 55-76; U. Gumuła, O księgozbiorze Lubomirskich z Niezdowa i Sanguszków z Gumnisk w zbiorach Biblioteki Ślaskiej, „Książnica Śląska” 24, 1988/1993, s. 59-86; W. Wojciechowski, Stare druki Biblioteki Mogielnickiej Starzeńskich i księgozbioru Muzeum Pokuckiego w Kołomyi w Bibliotece Śląskiej, „Książnica Śląska” 25, 1988/1994, s. 27-52; D. Musioł, E. Tyrna-Danielczyk, Masonika w zbiorach Biblioteki Śląskiej. Katalog, Katowice 1998; D. Bałycz, Druki religijne wydane w warszawskiej oficynie pijarskiej i zgromadzone w Bibliotece Ślaskiej w Katowicach (praca magisterska), Uniwersytet Warszawski, Warszawa 2009; L. Solarz, Stare druki warszawskiej oficyny jezuickiej w zbiorach Biblioteki Ślaskiej w Katowicach (praca magisterska), Uniwersytet Warszawski, Warszawa 2011; Polonica i silesiaca XVI wieku w zbiorach Biblioteki Ślaskiej, T. 1. A-R, red. W. Pawłowicz, T. Roszkowska, Katowice 2013; Polonica i silesiaca XVI wieku w zbiorach Biblioteki Ślaskiej. T. 2. S-Ż. Addenda, indeksy, red. W. Pawłowicz, T. Roszkowska, Katowice 2013; W. Pawłowicz, Z księgozbioru Schaffgotschów w Bibliotece Śląskiej. Stare druki, „Książnica Śląska” 30, 2018, s. 32-65; M. Ściążko, Aleksander i Rozalia Lubomirscy oraz ich księgozbiór w Bibliotece Śląsiej. Rekonesans, „Książnica Śląska" 30, 2018, s. 11-31.

\section{ROCZNIKI BIBLIOTECZNE}

ROK LXIII, 2019

(C) for this edition by CNS 


\begin{tabular}{|c|c|c|c|}
\hline 85 & Katowice & $\begin{array}{l}\text { Biblioteka Uniwersytetu Śląskiego } \\
\text { (od } 2012 \text { roku w ramach Centrum Informacji } \\
\text { Naukowej i Biblioteki Akademickiej) } \\
\text { ul. Bankowa 11A, 40-007 Katowice }\end{array}$ & 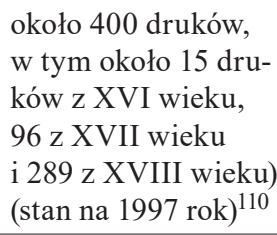 \\
\hline 86 & Katowice & $\begin{array}{l}\text { Biblioteka Wydziału Teologicznego } \\
\text { Uniwersytetu Śląskiego } \\
\text { ul. Wita Stwosza 17, 40-042 Katowice }\end{array}$ & 916 woluminów ${ }^{111}$ \\
\hline 87 & Katowice & $\begin{array}{l}\text { Muzeum Archidiecezjalne } \\
\text { (Dział starodruków oficyn śląskich) } \\
\text { ul. Jordana 39, 40-043 Katowice }\end{array}$ & $\begin{array}{l}\text { około } 1500 \text { druków } \\
\text { (nieopracowa- } \\
\text { nych) }\end{array}$ \\
\hline 88 & $\begin{array}{l}\text { Kazimierz } \\
\text { Biskupi }\end{array}$ & $\begin{array}{l}\text { Biblioteka Wyższego Seminarium Duchownego } \\
\text { Misjonarzy Świętej Rodziny } \\
\text { ul. Klasztorna 2, 62-350 Kazimierz Biskupi }\end{array}$ & 151 woluminów ${ }^{113}$ \\
\hline 89 & $\begin{array}{l}\text { Kazimierz } \\
\text { Dolny }\end{array}$ & $\begin{array}{l}\text { Klasztor pw. Zwiastowania Najświętszej } \\
\text { Maryi Panny } \\
\text { ul. Klasztorna 3, 24-120 Kazimierz Dolny }\end{array}$ & $\begin{array}{l}\text { brak szczegółowych } \\
\text { danych }^{114}\end{array}$ \\
\hline 90 & Kętrzyn & $\begin{array}{l}\text { Muzeum im. Wojciecha Kętrzyńskiego } \\
\text { pl. Zamkowy 1, 11-400 Kętrzyn }\end{array}$ & $\begin{array}{l}154 \text { druki (stan na } \\
2017 \text { rok) }\end{array}$ \\
\hline 91 & Kielce & $\begin{array}{l}\text { Biblioteka Klasztoru Sióstr Karmelitanek } \\
\text { Bosych } \\
\text { ul. św. R. Kalinowskiego 3, 25-143 Kielce }\end{array}$ & 6 woluminów ${ }^{116}$ \\
\hline
\end{tabular}

110 Polonika to aż 328 dzieł z całego zbioru starych druków - zob. L. Czech, Katalog starych druków w zbiorach Biblioteki Uniwersytetu Śląskiego, Katowice 1996, s. 5-6; http://gazeta. us.edu.pl/node/199201; zob. też https://integro.ciniba.edu.pl/integro/search/description?bID=19\&_ lang $=\mathrm{pl} \& \mathrm{q}=$ stare + druki\&inde $=4$.

111 Biblioteki Kościoła Katolickiego..., s. 64.

112 Są to druki z oficyn śląskich oraz polskie książki wydawane w Niemczech - Muzea Kościoła katolickiego..., s. 48-49; zob. też http://www.muzeum.archidiecezjakatowicka.com.pl/o-muzeum/.

113 Biblioteki Kościoła Katolickiego..., s. 162.

114 Zob. https://pl.wikipedia.org/wiki/Ko\%C5\%9Bci\%C3\%B3\%C5\%82_Zwiastowania_ Naj\%C5\%9Bwi\%C4\%99tszej_Maryi_Panny_i_klasztor_reformat\%C3\%B3w_w_Kazimierzu_Dolnym; http://www.polskaniezwykla.pl/web/place/8152,kazimierz-dolny-barokowy-zespol-klasztoru-reformatow-(xvii-w-).html.

$115 \mathrm{~W}$ ramach tego zbioru 64 druki pochodzą z dawnej biblioteki pałacowej w Arklitach — http://niestatystyczny.pl/2017/06/28/uratowane-starodruki/; http://www.muzeum.ketrzyn.pl/zbiory/; http://www.muzeum.ketrzyn.pl/2017/starodruki-z-palacu-w-arklitach-trafily-do-zbiorow-naszego-muzeum/; zob. też M. Sołtysiak, K. Wierzbicka, op. cit., s. 77.

116 Biblioteki Kościoła Katolickiego..., s. 236. 


\begin{tabular}{|c|c|c|c|}
\hline 92 & Kielce & $\begin{array}{l}\text { Biblioteka Wyższego Seminarium Duchownego } \\
\text { ul. Jana Pawła II 7, 25-025 Kielce }\end{array}$ & $\begin{array}{l}\text { około } 10096 \text { wo- } \\
\text { luminów, w tym } \\
96 \text { woluminów } \\
\text { inkunabułów } 117\end{array}$ \\
\hline 93 & Kielce & $\begin{array}{l}\text { Muzeum Narodowe (Biblioteka) } \\
\text { pl. Zamkowy 1, 25-010 Kielce }\end{array}$ & $\begin{array}{l}\text { ponad } 200 \text { druków } \\
\text { (stan na } 1988 \text { rok) }^{118}\end{array}$ \\
\hline 94 & Kielce & $\begin{array}{l}\text { Parafia Katedralna pw. Wniebowzięcia } \\
\text { Najświętszej Marii Panny (Skarbiec) } \\
\text { pl. Najświętszej Maryi Panny 3, 25-010 Kielce }\end{array}$ & $\begin{array}{l}\text { brak szczegółowych } \\
\text { danych }{ }^{119}\end{array}$ \\
\hline 95 & Kielce & $\begin{array}{l}\text { Wojewódzka Biblioteka Publiczna } \\
\text { im. Witolda Gombrowicza } \\
\text { ul. ks. Piotra Ściegiennego 13, 25-033 Kielce }\end{array}$ & $\begin{array}{l}\text { ponad } 6 \text { tysięcy dru- } \\
\text { ków (stan na } 2001 \\
\text { rok) }\end{array}$ \\
\hline 96 & Kluczbork & $\begin{array}{l}\text { Muzeum im. Jana Dzierżona } \\
\text { (Dział historii) } \\
\text { ul. Zamkowa 10, 46-200 Kluczbork }\end{array}$ & $\begin{array}{l}\text { brak szczegółowych } \\
\text { danych }{ }^{121}\end{array}$ \\
\hline 97 & Kłodzko & $\begin{array}{l}\text { Muzeum Ziemi Kłodzkiej } \\
\text { (Biblioteka Naukowa) } \\
\text { ul. Łukasiewicza 4, 57-300 Kłodzko }\end{array}$ & $\begin{array}{l}\text { brak szczegółowych } \\
\text { danych }^{122}\end{array}$ \\
\hline
\end{tabular}

117 Ibidem, s. 90; J. Witczak, Wspótpraca bibliotek kościelnych z Federacji Fides [wystąpienie na konferencji ,Zbiory specjalne polskich bibliotek naukowych w NUKAT”, Warszawa 25.11.2019]; zob. też http://wsd.kielce.pl/seminariumm/biblioteka-wsd.html?showall=\&start=1. Niemal 150 druków z tego zbioru pochodzi z klasztoru augustianów-eremitów w Książu Wielkim — zob. http:// wsd.kielce.pl/seminariumm/aktualnosci/341-starodruki-w-ksiazu-wielkim.html.

118 J. Kuczyński, W osiemdziesięciolecie Muzeum Narodowego w Kielcach, „Rocznik Muzeum Narodowego w Kielcach" 16, 1988, s. 17, http://bazhum.muzhp.pl/media//files/Rocznik_Muzeum_Narodowego_w_Kielcach/Rocznik_Muzeum_Narodowego_w_Kielcach-r1988-t16/Rocznik_Muzeum_Narodowego_w_Kielcach-r1988-t16-s13-33/Rocznik_Muzeum_Narodowego_w_ Kielcach-r1988-t16-s13-33.pdf; zob. też https://mnki.pl/pl/o_muzeum/biblioteka_muzealna; B. Skrzypczak, Biblioteka, „Rocznik Muzeum Narodowego w Kielcach” 24, 2009, s. 246, 252, http://bazhum.muzhp.pl/media//files/Rocznik_Muzeum_Narodowego_w_Kielcach/Rocznik_Muzeum_Narodowego_w_Kielcach-r2009-t24/Rocznik_Muzeum_Narodowego_w_Kielcach-r2009-t24-s245-255/Rocznik__Muzeum_Narodowego_w_Kiēcach-r2009-t24-s245-255.pdf.

119 Zob. http://www.kielcekatedra.pl/bazylika-katedralna-16817/skarbiec-16853; A. Kwaśniewski, Ksiegozbiory prywatne zachowane w Bibliotece Kapituly Kieleckiej (XV-XVIII wiek), „Biuletyn Biblioteki Jagiellońskiej” 62, 2012, s. 69-94.

$120 \mathrm{http}: / /$ www.wrota-swietokrzyskie.pl/329/-/asset_publisher/R29g/content/wojewodzka-biblioteka-publiczna-w-kielcach? redirect=http\%3A\%2F\%2Fwww.wrota-swietokrzyskie.pl\%2F329\%3Fp_p_id\%3D101_INSTANCE_R29g\%26p_p_lifecycle\%3D0\%26p_p_ state\%3Dnormal\%26p_p_mode\%3Dview\%26p_p_col_id\%3Dcolumn-2\%26p_p_col_count\%3D1.

121 https://www.muzeum.kluczbork.pl/zbiory/dzia-historii; M. Sołtysiak, K. Wierzbicka, op. cit., s. 81 .

122 Zob. http://muzeum.klodzko.pl/noc-muzeow-2018/2018-04-24; http://muzeum.klodzko. pl/kupione-i-podarowane-nabytki-muzeum-ziemi-klodzkiej-w-klodzku-2015-2017/2018-04-22. 


\begin{tabular}{|c|c|c|c|}
\hline 98 & Kłodzko & $\begin{array}{l}\text { Powiatowa i Miejska Biblioteka Publiczna } \\
\text { im. Marii Dąbrowskiej } \\
\text { pl. Bolesława Chrobrego 1, 57-300 Kłodzko }\end{array}$ & 81 druków $^{123}$ \\
\hline$\{98\}$ & $\{$ Kłodzko $\}$ & $\begin{array}{l}\text { \{Klasztor Franciszkanów } \\
\text { pl. Franciszkański 1, 57-300 Kłodzko\} }\end{array}$ & $\begin{array}{l}\text { \{około } 2 \text { tysiące } \\
\text { woluminów } \\
(\text { stan przed } 1997 \\
\left.\text { rokiem) }{ }^{124}\right\}\end{array}$ \\
\hline$\{98\}$ & $\{$ Kodeń\} & $\begin{array}{l}\text { \{Dom Zakonny Misjonarzy Oblatów Maryi } \\
\text { Niepokalanej } \\
\text { ul. Rynek 1, 21-509 Kodeń\} }\end{array}$ & $\begin{array}{l}\{\text { brak szczegóło- } \\
\text { wych danych }\end{array}$ \\
\hline 99 & Kolbuszowa & $\begin{array}{l}\text { Parafia Kolegiacka pw. Wszystkich Świętych } \\
\text { ul. Narutowicza 6, 36-100 Kolbuszowa }\end{array}$ & $\begin{array}{l}\text { co najmniej } 176 \text { dru- } \\
\text { ków (stan na } 2015 \\
\text { rok) }\end{array}$ \\
\hline 100 & Kołobrzeg & $\begin{array}{l}\text { Miejska Biblioteka Publiczna } \\
\text { im. Galla Anonima } \\
\text { ul. Frankowskiego 3, 78-100 Kołobrzeg }\end{array}$ & 1 wolumin ${ }^{127}$ \\
\hline 101 & Kołobrzeg & $\begin{array}{l}\text { Muzeum Oręża Polskiego } \\
\text { (Biblioteka i Gabinet Zbiorów Specjalnych) } \\
\text { Gierczak 5, 78-100 Kołobrzeg }\end{array}$ & $\begin{array}{l}19 \text { druków, w tym } \\
4 \text { (?) druki z XVII } \\
\text { wieku i } 15 \text { druków } \\
\text { z XVIII wieku } \\
\text { (stan na } 2012 \text { rok) }{ }^{128}\end{array}$ \\
\hline 102 & Konin & $\begin{array}{l}\text { Miejska Biblioteka Publiczna } \\
\text { ul. Dworcowa 13, 62-510 Konin }\end{array}$ & 4 woluminy ${ }^{129}$ \\
\hline 103 & Koszalin & $\begin{array}{l}\text { Koszalińska Biblioteka Publiczna } \\
\text { im. Joachima Lelewela } \\
\text { pl. Polonii 1, 75-415 Koszalin }\end{array}$ & 23 woluminy ${ }^{130}$ \\
\hline
\end{tabular}

123 Dane na podstawie kwerendy M. Kycler. Według http://biblioteka.klodzko.pl/zasoby-biblioteczne/ w 2017 roku w bibliotece znajdowało się 129 woluminów starych druków.

124 Zbiory te, zawierające również inkunabuły, zostały zalane podczas powodzi w 1997 roku. Informacje na podstawie http://old.nimoz.pl/pl/wydawnictwa/wydawnictwa-nimoz/cenne-bezcenne-utracone-1/cenne-bezcenne-utracone-archiwum/1998/nr-31998/ratujac-zbiory-biblioteczne-z-powodzi/print.

125 Zob. G. Chodynicka, Starodruki biblioteki oo. Oblatów w Kodniu (praca magisterska), Uniwersytet Marii Curie-Skłodowskiej, Lublin 1999.

126 https://nowiny24.pl/dyrektor-biblioteki-w-kolbuszowej-starodruki-z-xvi-wieku-beda-w-sieci/ar/5815737.

127 Dane na podstawie kwerendy M. Kycler.

128 Są to zbiory z zakresu historii, z czego 11 dzieł to polonika, a 8 pomeranika - zob. M. Kurzyńska, Kolekcje starych druków..., slajd 37-43; eadem, Druki pomorskie..., slajd 5-8.

129 Dane na podstawie kwerendy M. Kycler.

${ }^{130}$ Dane na podstawie kwerendy M. Kycler. 


\begin{tabular}{|c|c|c|c|}
\hline 104 & Koszalin & $\begin{array}{l}\text { Muzeum (Biblioteka) } \\
\text { ul. Młyńska 37-39, 75-420 Koszalin }\end{array}$ & 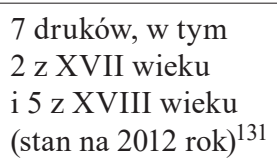 \\
\hline 105 & Kozłówka & $\begin{array}{l}\text { Muzeum Zamoyskich } \\
\text { Kozłówka 3, 21-132 Kamionka }\end{array}$ & 572 druki $^{132}$ \\
\hline 106 & Kórnik & $\begin{array}{l}\text { Biblioteka Kórnicka Polskiej Akademii Nauk } \\
\text { (Pracownia Starych Druków) } \\
\text { ul. Zamkowa 5, 62-035 Kórnik-Zamek }\end{array}$ & $\begin{array}{l}\text { około } 40 \text { tysięcy } \\
\text { druków, w tym } \\
\text { ponad } 200 \text { inkuna- } \\
\text { bułów } 133\end{array}$ \\
\hline 107 & Kraków & $\begin{array}{l}\text { Archiwum i Biblioteka Ojców Cystersów } \\
\text { w Mogile (niebawem jako Muzeum Duchowości } \\
\text { i Kultury Cystersów) } \\
\text { ul. Klasztorna 11, 31-979 Kraków }\end{array}$ & $\begin{array}{l}\text { około } 450 \text { woluminy, } \\
\text { w tym } 250 \text { wolumi- } \\
\text { nów inkunabułów } 134\end{array}$ \\
\hline 108 & Kraków & $\begin{array}{l}\text { Archiwum i Biblioteka Ojców Karmelitów } \\
\text { „Na Piasku” } \\
\text { ul. Karmelicka 19, 31-128 Kraków }\end{array}$ & $\begin{array}{l}\text { około } 15262 \text { wo- } \\
\text { luminów, w tym } \\
317 \text { inkuna- } \\
\text { bułów (w } 262 \\
\text { woluminach) }^{135}\end{array}$ \\
\hline
\end{tabular}

131 Są to zbiory z zakresu historii i teologii — zob. M. Kurzyńska, Kolekcje starych druków..., slajd 37-43; eadem, Druki pomorskie..., slajd 5-8.

$132 \mathrm{https} / / / w w w . m u z e u m z a m o y s k i c h . p l / 174$, biblioteka. Według http://zzwp.wroclaw. pl/2018/10/30/4-dniowa-wycieczka-sandomierz-zamosc-lublin-kozlowka-kazimierz-dolny/ w muzeum znajduje się 620 starych druków.

$133 \mathrm{~W}$ zbiorze tym znajdują się również ponad 2 tysiące poloników z XVII wieku - zob. http://www.bkpan.poznan.pl/biblioteka/zbiory/starodruki/. Zgodnie z informacją na stronie http:// www.bkpan.poznan.pl/biblioteka/ stan zbiorów starodrucznych wynosi 30 tysięcy druków. Zob. też http://bazal-bis.man.poznan.pl/cgi-bin/makwww.exe?BZ=Stare_druki; K. Piekarski, Katalog Biblioteki Kórnickiej, T. 1. Polonika XVI-go wieku, Kraków 1929; Katalog Starych Druków Biblioteki Kórnickiej, T. 1. Polonica XVI w., cz. 2. Nowe nabytki i uzupetnienia, oprac. P. Buchwald-Pelcowa, Wrocław 1969; R.T. Prinke, „Ars quam chemiam vocant”. Starodruki alchemiczne w zbiorach Biblioteki Kórnickiej, „Pamiętnik Biblioteki Kórnickiej” 26, 2003, s. 161-198; K. Kubiś, Stare druki z kościoła św. Jana w Lesznie w zbiorach biblioteki kórnickiej (praca magisterska), Uniwersytet Mikołaja Kopernika, Torun 2002.

134 Biblioteki Kościoła Katolickiego..., s. 139; zob. http://www.mogila.cystersi.pl/index.php?option=com_content\&view=article \&id=164:archiwum-i-biblioteka-cystersow-w-mogile\&catid=41:archiwum-i-biblioteka\&Itemid=136. W przedwojennym katalogu inkunabułów wymieniono 247 inkunabułów — zob. G. Kowalski, Katalog inkunabułów biblioteki Opactwa mogilskiego, oraz katalog inkunabułów biblioteki klasztoru Cystersów w Szczyrzycu, Kraków 1915, https://www.sbc.org.pl/dlibra/publication/61429/edition/58700/content?ref=desc. Według http://www.mogila.cystersi.pl/index.php?option=com_content\&view=article\&id=164:archiwum-i-biblioteka-cystersow-w-mogile\&catid=41:archiwum-i-biblioteka\&Itemid=136 zbiór ten w 1927 roku zawierał 30 poloników z XVI wieku. Zob. też H. Kuna, Druki polskie z XVII wieku w zbiorach biblioteki klasztoru oo. Cystersów w Mogile (praca magisterska), Wyższa Szkoła Pedagogiczna im. Komisji Edukacji Narodowej, Kraków 1979.

135 Według https://www.gluseum.com/PL/Krak\%C3\%B3w/240486536073205/Archiwum-i-Biblioteka-OO.-Karmelit\%C3\%B3w-na-Piasku w zbiorach tych znajduje się około 12 tysię-

\section{ROCZNIKI BIBLIOTECZNE}

ROK LXIII, 2019

(C) for this edition by CNS 


\begin{tabular}{|c|l|l|l|}
\hline 109 & Kraków & $\begin{array}{l}\text { Archiwum Krakowskiej Kapituły Katedralnej } \\
\text { Wawel 3, 31-001 Kraków }\end{array}$ & $\begin{array}{l}\text { 3208 druków, w tym } \\
\text { 272 inkunabuły } \\
\text { (poza tym Biblio- } \\
\text { teka Kapitulna } \\
\text { posiada 344 ,sta- } \\
\text { rodruki i druki } \\
\text { muzyczne”) }\end{array}$ \\
\hline 110 & Kraków & $\begin{array}{l}\text { Archiwum Polskiej Prowincji Zakonu Pijarów } \\
\text { (Biblioteka Starodruków) } \\
\text { ul. Pijarska 2, 31-015 Kraków }\end{array}$ & $\begin{array}{l}\text { 2262 druki } \\
\text { (w 1884 wolu- } \\
\text { minach), w tym } \\
\text { 35 inkunabułów } \\
\text { (w 22 wolumi- } \\
\text { nach) }\end{array}$ \\
\hline 111 & Kraków & $\begin{array}{l}\text { Biblioteka Braci Mniejszych Kapucynów } \\
\text { ul. Loretańska 11, 31-114 Kraków }\end{array}$ & $\begin{array}{l}\text { 5578 woluminów, } \\
\text { w tym 15 wolumi- } \\
\text { nów inkunabułów }\end{array}$ \\
\hline 112 & Kraków & $\begin{array}{l}\text { Biblioteka Główna Akademii Górniczo-Hutni- } \\
\text { czej im. Stanisława Staszica } \\
\text { al. Mickiewicza 30, 30-059 Kraków }\end{array}$ & $\begin{array}{l}\text { brak szczegółowych } \\
\text { danych }\end{array}$ \\
\hline 113 & $\begin{array}{l}\text { Kiblioteka Główna Akademii Sztuk Pięknych } \\
\text { im. Jana Matejki (Zbiory specjalne) } \\
\text { ul. Smoleńsk 9, 31-108 Kraków }\end{array}$ & $\begin{array}{l}\text { brak szczegółowych } \\
\text { danych }\end{array}$ \\
\hline
\end{tabular}

cy starych druków, w tym ponad 300 inkunabułów. Zob. też S. Sułecki, Księgozbiór klasztoru karmelitów na Piasku w Krakowie, Kraków 2014; B. Ćwik, Druki polskojęzyczne w XVI-XVII wieku w zbiorach Biblioteki Klasztoru oo. Karmelitów Trzewiczkowych na Piasku w Krakowie (praca magisterska), Wyższa Szkoła Pedagogiczna im. Komisji Edukacji Narodowej, Kraków 1993; W. Kolak, Katalog Klasztoru Ojców Karmelitów w Krakowie „Na Piasku”, Kraków 1997; M. Dyba, Rękopisy i inkunabuty (XIV-XVI wiek) oraz ich dekoracja malarska i kaligraficzna w zbiorach Biblioteki Klasztoru OO. Karmelitów Trzewiczkowych na Piasku w Krakowie (praca magisterska), Uniwersytet Papieski Jana Pawła II w Krakowie, Kraków 2010.

136 Archiwa Kościoła Katolickiego..., s. 46. Według http://akkk.com.pl/zasob/starodruki zbiór ten liczy około 3 tysięcy woluminów. Zob. też M. Kot, Inkunabuły Margarita Decreti Marcina Polaka w Archiwum Kapituly Krakowskiej i bibliotekach krakowskich (praca magisterska), Papieska Akademia Teologiczna, Kraków 1986.

137 Biblioteki Kościoła Katolickiego..., s. 211; zob. też http://www.kuria.pijarzy.pl/zakon_i_ jego_historia/z_pijarskiego_archiwum/przyczynki_do_historii_archiwum_prowincji_i_biblioteki_starodrukow_d5434_pol.html.

138 Biblioteki Kościoła Katolickiego..., s. 200; zob. też https://www.biblioteka.kapucyni.pl/ home/info; M. Pęchalska, Druki XVIII-wieczne w języku polskim wydane w Krakowie w zbiorach oo. kapucynów (praca magisterska), Wyższa Szkoła Pedagogiczna, Kraków 1993; M. Toroń, Druki XVI- i XVII-wieczne w języku polskim w zbiorach Biblioteki oo. Kapucynów w Krakowie (praca magisterska), Wyższa Szkoła Pedagogiczna, Kraków 1993; M. Sołtysiak, K. Wierzbicka, op. cit., s. 94.

139 Zob. http://www.bg.agh.edu.pl/pl/node/213; https://pl.wikipedia.org/wiki/Biblioteka_G\% C5\%82\%C3\%B3wna_Akademii_G\%C3\%B3rniczo-Hutniczej.

140 Zob. http://bg.asp.krakow.pl/bg/index.php/zasady-korzystania. 


\begin{tabular}{|c|l|l|l|}
\hline 114 & Kraków & $\begin{array}{l}\text { Biblioteka Główna Uniwersytetu Papieskiego } \\
\text { Jana Pawła II w Krakowie } \\
\text { ul. Bobrzyńskiego 10, 30-348 Kraków }\end{array}$ & $\begin{array}{l}\text { około 6 tysięcy } \\
\text { druków, w tym } \\
10 \text { inkunabułów }\end{array}$ \\
\hline 115 & Kraków & $\begin{array}{l}\text { Biblioteka i Archiwum Konwentu Bonifratrów } \\
\text { ul. Krakowska 48, 31-066 Kraków }\end{array}$ & 1876 druków ${ }^{142}$ \\
\hline 116 & Kraków & $\begin{array}{l}\text { Biblioteka Jagiellońska } \\
\text { (Sekcja Starych Druków) } \\
\text { al. Mickiewicza 22, 30-059 Kraków }\end{array}$ & $\begin{array}{l}109160 \text { druków, } \\
\text { w tym 3666 inku- } \\
\text { nabułów oraz około } \\
4200 \text { woluminów } \\
\text { czasopism }^{143}\end{array}$ \\
\hline 117 & Kraków & $\begin{array}{l}\text { Biblioteka Klasztoru Karmelitów Bosych } \\
\text { ul. Rakowicka 18, 31-510 Kraków }\end{array}$ & $\begin{array}{l}5 \text { tysięcy wolumi- } \\
\text { nów }\end{array}$ \\
\hline
\end{tabular}

141 http://biblioteka.upjp2.edu.pl/node/45; J. Witczak, op. cit.; zob. też http://bc.upjp2.edu.pl/ dlibra/collectiondescription?dirids=28; T. Bryg, Druki XVIII-wieczne $w$ języku polskim $w$ zbiorach Biblioteki Papieskiej Akademii Teologicznej w Krakowie: drukarnie zakonne (praca magisterska), Wyższa Szkoła Pedagogiczna im. Komisji Edukacji Narodowej, Kraków 1997); M. Chudzikiewicz, Druki XVIII-wieczne w języku polskim w zbiorach Biblioteki Papieskiej Akademii Teologicznej w Krakowie: drukarnie świeckie i kościelne (praca magisterska), Wyższa Szkoła Pedagogiczna im. Komisji Edukacji Narodowej, Kraków 1997.

142 https://bonifratrzy.pl/klasztor-krakow/biblioteka-i-archiwum/zasob/.

143 Około 2700 pozycji (prawie 3800 egzemplarzy) to polonika z XVI wieku — zob. http:// www.bj.uj.edu.pl/zbiory-biblioteczne-uj; http://www.bj.uj.edu.pl/stare-druki. Według J. Partyki (Starodruki Biblioteki Jagiellońskiej - Stan Opracowania, Proweniencje, Perspektywy Badawcze, Wratislaviae, a.d. III Kal. Oct. CID CID XVI, https://docplayer.pl/51298544-Starodruki-biblioteki-jagiellonskiej-stan-opracowania-proweniencje-perspektywy-badawcze.html) w bibliotece znajduje się 108131 starych druków, w tym 2345 edycji inkunabułów (około 3750 egzemplarzy), 17665 edycji druków z XVI wieku (około 20 tysięcy egzemplarzy), 16777 rekordów druków z XVII wieku (20 169 egzemplarzy) [w NUKAT] oraz 5088 rekordów druków z XVIII wieku (7611 egzemplarzy) [w NUKAT]. Biblioteka posiada również dublety i depozyty, to jest tak zwane dublety ze starego zasobu (około 10 tysięcy), tak zwane dublety augustiańskie (około 5-6 tysięcy), Berlinka (20 600), księgozbiór Eremu Srebrnej Góry (9155), księgozbiór Eremu Pięciu Męczenników (1919), księgozbiór reformatów z Biecza (2049) (stan na 2016 rok). Zob. też A. Lewicka-Kamińska, Inkunabuty Biblioteki Jagiellońskiej, Kraków, 1962; J. Szocki, Ksieggozbiór domowy Józefa Szujskiego (w świetle sporządzonych jego ręka katalogów), cz. 1, „Biuletyn Biblioteki Jagiellońskiej" 39, 1989, nr 1-2, s. 102-119; idem, Księgozbiór domowy Józefa Szujskiego (w świetle sporządzonych jego ręką katalogów), cz. 2, „Biuletyn Biblioteki Jagiellońskiej” 40, 1990, nr 1-2, s. 34-124; Katalog poloników XVI wieku Biblioteki Jagiellońskiej, red. M. Malicki, E. Zwinogrodzka, T. 1-2, Kraków 1992-1994; Catalogus librorum saeculi XVI qui in Bibliotheca Iagellonica Cracoviensis asseervantur, BJ 16, T. 1-8, Baden 2002-2007; Skarby Biblioteki Jagiellońskiej, red. Z. Pietrzyk, Kraków 2005; Biblioteka Jagiellońska - skarbiec bibliofila, red. M. Malicki, Kraków-Pelplin 2011; J. Partyka, Historyczny księgozbiór kamedułów eremitów z krakowskich Bielan: spojrzenie na kulturę materialno-duchowa polskich kamedułów, Kraków 2017.

144 Biblioteki Kościoła Katolickiego..., s. 153; J. Witczak, op. cit.; http://communiocrucis.pl/ index.php/warto-poczyta/584-100-lecie-karmelitow-bosych-w-krakowie-przy-rakowickiej. 


\begin{tabular}{|c|l|l|l|}
\hline 118 & Kraków & $\begin{array}{l}\text { Biblioteka Kolegium Filozoficzno-Teologiczne- } \\
\text { go Polskiej Prowincji Dominikanów } \\
\text { ul. Stolarska 12, 31-043 Kraków }\end{array}$ & $\begin{array}{l}18948 \text { druki, w tym } \\
445 \text { woluminów } \\
\text { inkunabułów }\end{array}$ \\
\hline 119 & Kraków & $\begin{array}{l}\text { Biblioteka Książąt Czartoryskich } \\
\text { (oddział Muzeum Narodowego) } \\
\text { ul. św. Marka 17, 31-018 Kraków }\end{array}$ & $\begin{array}{l}70009 \text { druków, } \\
\text { w tym 333 inkuna- } \\
\text { buły146 }\end{array}$ \\
\hline 120 & Kraków & $\begin{array}{l}\text { Biblioteka Naukowa i Archiwum } \\
\text { (Muzeum Historyczne Miasta Krakowa) } \\
\text { Rynek Główny 35, 31-011 Kraków }\end{array}$ & 143 woluminy ${ }^{147}$ \\
\hline 121 & Kraków & $\begin{array}{l}\text { Biblioteka Naukowa Księży Jezuitów/ } \\
\text { Biblioteka Akademii „Ignatianum” } \\
\text { ul. Mikołaja Kopernika 26, 31-501 Kraków }\end{array}$ & $\begin{array}{l}20 \text { tysięcy druków } \\
\text { w 30 tysiącach } \\
\text { woluminów (stan na } \\
2002 \text { rok) }\end{array}$ \\
\hline 122 & Kraków & $\begin{array}{l}\text { Biblioteka Naukowa Polskiej Akademii } \\
\text { Umiejętności i Polskiej Akademii Nauk } \\
\text { ul. Sławkowska 17, 31-016 Kraków }\end{array}$ & $\begin{array}{l}17045 \text { druków, } \\
\text { w tym 155 inkuna- } \\
\text { bułów }\end{array}$ \\
\hline 123 & Kraków & $\begin{array}{l}\text { Biblioteka Panien Prezentek } \\
\text { ul. św. Jana 7, 31-017 Kraków }\end{array}$ & 162 woluminy ${ }^{150}$ \\
\hline
\end{tabular}

145 J. Witczak, op. cit. Według Bibliotek Kościoła Katolickiego... (s. 141) w 2005 roku w bibliotece znajdowało się 445 woluminów inkunabułów oraz około 25 woluminów starych druków. Według https://kolegium.dominikanie.pl/biblioteka/ zbiór ten liczy prawie 20 tysięcy starych druków. W zbiorze tym znajdują się liczne polonika z XVI wieku. Zob. też Tradycja tomistyczna w zbiorach biblioteki Studium OO. Dominikanów w Krakowie. Katalog druków: XV-XVIII w., oprac. M. Mydel, Ż. Kubic, „Przegląd Tomistyczny” 13, 2007, nr 2, http://bc.dominikanie.pl/publication/321; M. Urbaniak, Inkunabuty Biblioteki Zakonu Dominikanów w Krakowie w świetle Centralnego Katalogu Inkunabułów (praca magisterska), Uniwersytet Mikołaja Kopernika, Toruń 2005.

146 https://pl.wikipedia.org/wiki/Biblioteka_Ksi\%C4\%85\%C5\%BC\%C4\%85t_Czartoryskich; http://mnk.pl/oddzial/biblioteka-ksiazat-czartoryskich/zbiory/fotogalerie/druki. Według M. Sołtysiak i K. Wierzbickiej (op. cit., s. 95) w 1997 roku zbiór ten przedstawiał się następująco: „Dział Druków i Kartografii - starodruki polskie i Polski dotyczące, w tym 340 inkunabułów, ok. 4500 druków z XVI w., duży zbiór dzieł polskich i obcych z XVIII w. [...], czasopisma polskie i obce z XVIII-XIX w.; zbiory kartograficzne (3500 obiektów, w tym ok. 2000 z XVI-XVIII w.)".

$147 \mathrm{~W}$ ramach tego zbioru 55 woluminów określono jako cracoviana — zob. https://www. mhk.pl/zbiory/biblioteka-i-archwium.

148 http://www.ebib.pl/2002/35/grzebien.php.

149 http://pau.krakow.pl/index.php/pl/struktura/biblioteka-naukowa-pau-i-pan; http://149.156. 51.45/zbiory/zbiory-specjalne/stare-druki; zob. też Katalog inkunabułów Biblioteki Naukowej PAU i PAN w Krakowie, oprac. T. Dąbrowa, E. Knapek, J. Wojtowicz, Kraków 2015; R. Żurkowa, Stare druki z ksiegozbioru Cypriana Walewskiego w Bibliotece PAN w Krakowie, ,Rocznik Biblioteki Naukowej PAU i PAN w Krakowie" 44, 1999, s. 45-59; 45, 2000, s. 417-447; 46, 2001, s. 105-130.

150 Biblioteki Kościoła Katolickiego..., s. 253. 


\begin{tabular}{|c|l|l|l|}
\hline 124 & Kraków & $\begin{array}{l}\text { Biblioteka Prowincjalna Franciszkanów } \\
\text { (OFMConv) } \\
\text { pl. Wszystkich Świętych 5, 31-004 Kraków }\end{array}$ & $\begin{array}{l}\text { ponad 6300 druków, } \\
\text { w tym około 300 in- } \\
\text { kunabułów }{ }^{151}\end{array}$ \\
\hline 125 & Kraków & $\begin{array}{l}\text { Biblioteka Prowincji Ojców Bernardynów } \\
\text { (Archiwum Prowincji oraz Centralna Bibliote- } \\
\text { ka Starodruków Prowincji) } \\
\text { ul. Bernardyńska 2, 30-960 Kraków }\end{array}$ & $\begin{array}{l}\text { około 14 666 wo- } \\
\text { luminów, w tym } \\
\text { 666 woluminów } \\
\text { inkunabułów }\end{array}$ \\
\hline 126 & Kraków & $\begin{array}{l}\text { Biblioteka Sapiehów z Krasiczyna w Zamku } \\
\text { Królewskim na Wawelu } \\
\text { (Państwowe Zbiory Sztuki) } \\
\text { Wawel 5, 31-001 Kraków }\end{array}$ & $\begin{array}{l}2147 \text { druków } \\
\text { (szacunkowo; stan } \\
\text { na 2017 rok) } \\
\text { w około 1300 wo- } \\
\text { luminach (stan na } \\
2013 \text { rok) }\end{array}$ \\
\hline 127 & Kraków & $\begin{array}{l}\text { Biblioteka Sióstr Albertynek } \\
\text { ul. Woronicza 10, 31-409 Kraków }\end{array}$ & 20 woluminów \\
\hline
\end{tabular}

151 http://biblioteka.franciszkanska4.pl/zbiory/; http://biblioteka.franciszkanska4.pl/o-bibliotece/. Według Bibliotek Kościoła Katolickiego... (s. 148) w 2005 roku zbiory te liczyły 6010 woluminów starych druków, w tym około 10 woluminów inkunabułów.

152 Biblioteki Kościoła Katolickiego..., s. 184; https://dzieje.pl/dziedzictwo-kulturowe/krakow-oo-bernardyni-zaprezentowali-kolejne-inkunabuly-po-konserwacji: „W bibliotece i archiwum Prowincji OO. Bernardynów w Krakowie znajduje się blisko 700 cennych inkunabułów i kilkanaście tysięcy innych starych druków" (wypowiedź z 2015 roku); http://krakow.naszemiasto. $\mathrm{pl} /$ artykul/cenne-starodruki-bernardynow-po-konserwacji-zdjecia,2681776, artgal,t,id,tm.html: „W zakonnej bibliotece i archiwum jest ok. 12 tys. woluminów [starych druków - K.S.], ponad 100 rękopiśmiennych kodeksów liturgicznych i ponad 1 tys. kodeksów bibliotecznych" (stan na 2014 rok). Zob. też J. Chwastek, Druki polskojęzyczne z I pot. XVIII wieku w zbiorach Biblioteki Klasztoru Bernardynów w Krakowie (praca magisterska), Wyższa Szkoła Pedagogiczna im. Komisji Edukacji Narodowej, Kraków 1997; R. Wajda, Druki siedemnastowieczne w języku polskim w księgozbiorze klasztoru oo. Bernardynów w Krakowie (praca magisterska), Wyższa Szkoła Pedagogiczna im. Komisji Edukacji Narodowej, Kraków 1998.

$153 \mathrm{~W}$ ramach tego zbioru polonika z XVI-XVIII wieku to 810 pozycji, druki obce z XVXVII wieku - 322 pozycje (w tym 8 poloników i 4 inkunabuły), a druki obce z XVIII wieku 1052 pozycje (w tym 29 poloników oraz polonika i druki obce z XVI-XVII wieku odnalezione pod koniec prac nad katalogiem) - zob. Biblioteka Sapiehów z Krasiczyna w Zamku Królewskim na Wawelu, T. 1. Katalog starych druków. Polonica z wieków XVI-XVIII, oprac. i red. nauk. S. Siess-Krzyszkowski, K. Stompór-Lesiecka, A. Baran, Kraków 2013; Biblioteka Sapiehów z Krasiczyna w Zamku Królewskim na Wawelu, T. 2, cz. 1. Katalog starych druków. Druki obce z wieków XVXVII, red. nauk. I. Pietrzkiewicz, Kraków 2015, zwł. s. XVI; Biblioteka Sapiehów z Krasiczyna w Zamku Królewskim na Wawelu, T. 2, cz. 2. Katalog starych druków. Druki obce z wieku XVIII, red. nauk. I. Pietrzkiewicz, Kraków 2017, zwł. s. VII-VIII. We wstępie do tomu 1 na s. XII podano: „W liczącej obecnie ponad 13000 woluminów Bibliotece Krasiczyńskiej starodruki stanowią mniej więcej jedną dziesiątą zasobów". Zob. też https://www.wawel.krakow.pl/sklep/Biblioteka-Sapiehow-z-Krasiczyna-w-Zamku-Krolewskim-na-Wawelu-t2--cz1-Katalog-starych-drukow-Druki-o;s,karta,id,201; Biblioteka Sapiehów z Krasiczyna w Zamku Królewskim na Wawelu. Katalog wystawy 18 marca-31 maja 2014, red. M. Podlodowska-Reklewska, Kraków 2014.

154 Biblioteki Kościoła Katolickiego..., s. 217. 


\begin{tabular}{|c|c|c|c|}
\hline 128 & Kraków & $\begin{array}{l}\text { Biblioteka Wyższego Seminarium Duchownego } \\
\text { Misjonarzy Saletynów } \\
\text { ul. Koszalińska 12, 30-407 Kraków }\end{array}$ & 10 woluminów 155 \\
\hline 129 & Kraków & $\begin{array}{l}\text { Biblioteka Wyższego Seminarium Duchownego } \\
\text { Ojców Redemptorystów } \\
\text { ul. Zamoyskiego 56, 30-523 Kraków }\end{array}$ & około 200 druków ${ }^{156}$ \\
\hline 130 & Kraków & $\begin{array}{l}\text { Biblioteka Wyższego Seminarium Duchownego } \\
\text { Prowincji Matki Bożej Anielskiej } \\
\text { (Archiwum Prowincji Franciszkanów-Refor- } \\
\text { matów) } \\
\text { ul. Ojcowska 1, 31-344 Kraków } \\
\text { (Archiwum i Biblioteka Główna Prowincji } \\
\text { ul. Reformacka 4, 31-012 Kraków) }\end{array}$ & $\begin{array}{l}4300 \text { druków zareje- } \\
\text { strowanych i około } \\
8 \text { tysięcy do opraco- } \\
\text { wania oraz } 53 \text { wolu- } \\
\text { miny inkunabułów } \\
\text { (stan na } 2005 \text { rok) }^{157}\end{array}$ \\
\hline 131 & Kraków & $\begin{array}{l}\text { Biblioteka Wyższego Seminarium Duchownego } \\
\text { Towarzystwa Salezjańskiego } \\
\text { ul. Tyniecka 39, 30-323 Kraków }\end{array}$ & 1108 woluminów 158 \\
\hline 132 & Kraków & $\begin{array}{l}\text { Biblioteka Zgromadzenia Księży Misjonarzy } \\
\text { (na Stradomiu) } \\
\text { ul. Stradomska 4, 31-058 Kraków }\end{array}$ & $\begin{array}{l}\text { około } 30040 \text { wolu- } \\
\text { minów, w tym około } \\
40 \text { woluminów inku- } \\
\text { nabułów } 159\end{array}$ \\
\hline
\end{tabular}

155 Ibidem, s. 169.

156 Ibidem, s. 166.

157 Ibidem, s. 212. J. Witczak (op. cit.) podaje, że w zbiorach tych znajduje się 13 tysięcy druków. Zob. też http://popotam.ayz.pl/bibwsdofm/.

158 Biblioteki Kościoła Katolickiego..., s. 171.

159 Ibidem, s. 158. Według http://biblioteka.misjonarze.pl/?page_id=195 biblioteka posiada zbiór ponad 18 tysięcy starych druków. Z kolei według J. Witczaka (op. cit.) w kolekcji tej znajduje się 15040 starych druków, w tym 40 inkunabułów. Zob. też K. Socha, Między katalogowaniem a digitalizacja. Projekt bazy starodruków z Biblioteki Księży Misjonarzy na Stradomiu w Krakowie, „Fides: Biuletyn Bibliotek Kościelnych” 2, 2012, s. 109-114; L. Moskal, Druki polskojęzyczne z XVII wieku w Bibliotece Księży Misjonarzy na Stradomiu (praca magisterska), Wyższa Szkoła Pedagogiczna im. Komisji Edukacji Narodowej, Kraków 1997; J. Malik, Druki polskojęzyczne I połowy XVIII wieku w Bibliotece Księży Misjonarzy na Stradomiu w Krakowie (praca magisterska), Wyższa Szkoła Pedagogiczna im. Komisji Edukacji Narodowej, Kraków 1997; A. Szewc, Druki w języku polskim w Bibliotece Zgromadzenia Księży Misjonarzy na Stradomiu (praca magisterska), Wyższa Szkoła Pedagogiczna im. Komisji Edukacji Narodowej, Kraków 1998; M. Celer, Starodruki polskojęzyczne w Bibliotece Księży Misjonarzy w Krakowie. Funkcja informacyjna i reklamowa zestawienia bibliograficznego za okres 1771-1785 (praca magisterska), Akademia Pedagogiczna im. Komisji Edukacji Narodowej, Kraków 2004; A.B. Matura-Trzósło, Kleparskie starodruki polskojęzyczne w Bibliotece Księży Misjonarzy na Stradomiu (praca magisterska), Akademia Pedagogiczna im. Komisji Edukacji Narodowej w Krakowie, Kraków 2004; M. Dzidek, Siedemnastowieczne druki krakowskie ze zbiorów Biblioteki Zgromadzenia Księży Misjonarzy na Stradomiu (praca magisterska), Akademia Pedagogiczna im. Komisji Edukacji Narodowej, Kraków 2006.

\section{ROCZNIKI BIBLIOTECZNE}

ROK LXIII, 2019

(C) for this edition by CNS 


\begin{tabular}{|c|c|c|c|}
\hline 133 & Kraków & $\begin{array}{l}\text { Klasztor Bożego Ciała } \\
\text { (Kanonicy Regularni Laterańscy) } \\
\text { ul. Bożego Ciała 26, 31-059 Kraków }\end{array}$ & $\begin{array}{l}\text { prawie } 8 \text { tysięcy } \\
\text { druków, w tym } \\
238 \text { inkunabułów } \\
\text { (stan na } 2018 \text { rok) }^{160}\end{array}$ \\
\hline 134 & Kraków & $\begin{array}{l}\text { Klasztor Ojców Paulinów (na Skałce) } \\
\text { ul. Skałeczna 15, 31-065 Kraków }\end{array}$ & $\begin{array}{l}23 \text { woluminy inku- } \\
\text { nabułów }^{161}\end{array}$ \\
\hline$\{134\}$ & $\{$ Kraków\} & $\begin{array}{l}\text { \{Klasztor Sióstr Bernardynek } \\
\text { ul. Poselska 21, 31-002 Kraków\} }\end{array}$ & $\begin{array}{l}\text { \{brak szczegóło- } \\
\text { wych danych\} }\end{array}$ \\
\hline 135 & Kraków & $\begin{array}{l}\text { Klasztor Sióstr Karmelitanek Bosych } \\
\text { na Wesołej (Biblioteka/Archiwum) } \\
\text { ul. Kopernika 44, 31-501 Kraków }\end{array}$ & $\begin{array}{l}\text { około } 3 \text { tysięcy dru- } \\
\text { ków (stan na } 2016 \\
\text { rok) }\end{array}$ \\
\hline 136 & Kraków & $\begin{array}{l}\text { Klasztor Sióstr Klarysek } \\
\text { ul. Grodzka 54, 31-044 Kraków }\end{array}$ & $\begin{array}{l}\text { brak szczegółowych } \\
\text { danych }^{163}\end{array}$ \\
\hline 137 & Kraków & $\begin{array}{l}\text { Klasztor Sióstr Norbertanek na Salwatorze } \\
\text { (Biblioteka) } \\
\text { ul. Kościuszki 88, 30-114 Kraków }\end{array}$ & 400 woluminów ${ }^{164}$ \\
\hline 138 & Kraków & $\begin{array}{l}\text { Klasztor Sióstr Wizytek } \\
\text { ul. Krowoderska 16, 31-142 Kraków }\end{array}$ & $\begin{array}{l}\text { brak szczegółowych } \\
\text { danych }\end{array}$ \\
\hline$\{138\}$ & $\{$ Kraków\} & $\begin{array}{l}\text { \{Mniszki Zakonu Kaznodziejskiego } \\
\text { (Klasztor na Gródku) } \\
\text { ul. Mikołajska 21, 31-027 Kraków\} }\end{array}$ & $\begin{array}{l}\text { \{brak szczegóło- } \\
\text { wych danych\} }\end{array}$ \\
\hline 139 & Kraków & $\begin{array}{l}\text { Muzeum Etnograficzne im. Seweryna Udzieli } \\
\text { (Biblioteka) } \\
\text { ul. Krakowska 46, 31-066 Kraków }\end{array}$ & $\begin{array}{l}39 \text { woluminów } \\
\text { z XVII-XVIII } \\
\text { wieku }^{166}\end{array}$ \\
\hline
\end{tabular}

160 http://www.bozecialo.net/index.php/bazylika/przewodniki-menu/przewodnik-bazylika/251-klasztor; zob. też M. Jastrzemska, Inkunabuty biblioteki księży Kanoników Regularnych Latereńskich w Krakowie w świetle Centralnego Katalogu Inkunabułów (praca licencjacka), Uniwersytet Mikołaja Kopernika, Toruń 2003.

161 Biblioteki Kościoła Katolickiego..., s. 165; zob. też http://gazeta.us.edu.pl/node/226931; https://krakowskienoce.pl/zalacznik/36722.

162 Są to niemal wyłącznie druki w języku polskim — zob. E. Zmuda, Rękopisy z Archiwum Karmelitanek Bosych Krakowie, na Wesołej, jako źródto do badań językoznawczych, „Małopolska" 18, 2016, s. 37, przyp. 33, http://www.malopolska.org/images/pliki/roczniki/rm_18_2016/ rm_18_2016_s.33-43.pdf. Według Bibliotek Kościoła Katolickiego... (s. 238) w 2005 roku w zbiorach tych znajdowało się 2500 woluminów zinwentaryzowanych starych druków (częściowo współoprawnych). Zob. też C. Gil, Życie codzienne karmelitanek bosych w Polsce w XVII-XIX w., Kraków 1997, s. 93-100.

163 Zob. http://encyklopediakrakowa.pl/architektura-i-urbanistyka/swiatynie/136-klasztory /96-klasztor-klarysek.html.

164 Biblioteki Kościoła Katolickiego..., s. 252; zob. też http://encyklopediakrakowa.pl/swiatynie/koscioly/98-klasztor-norbertanek.html.

165 Zob. http://encyklopediakrakowa.pl/architektura-i-urbanistyka/swiatynie/136-klasztory/ 172-klasztor-wizytek.html.

166 D. Rak, Stare druki w zbiorach Biblioteki Muzeum Etnograficznego w Krakowie, „Bibliotheca Nostra. Śląski kwartalnik naukowy” 2015, nr 3 (41), s. 98-115, zwł. s. 100. 


\begin{tabular}{|c|l|l|l|}
\hline 140 & Kraków & $\begin{array}{l}\text { Muzeum Farmacji (Collegium Medicum } \\
\text { Uniwersytetu Jagiellońskiego) } \\
\text { ul. Floriańska 25, 31-019 Kraków }\end{array}$ & $\begin{array}{l}\text { 260 druków } \\
\text { (stan na 2015 rok) })^{167}\end{array}$ \\
\hline 141 & Kraków & $\begin{array}{l}\text { Muzeum im. Emeryka Hutten-Czapskiego } \\
\text { (oddział Muzeum Narodowego) } \\
\text { ul. Piłsudskiego 12, 31-109 Kraków }\end{array}$ & $\begin{array}{l}\text { ponad 26 tysięcy } \\
\text { druków } 168\end{array}$ \\
\hline 142 & Kraków & $\begin{array}{l}\text { Muzeum im. św. Józefa Sebastiana Pelczara } \\
\text { ul. Garncarska 24, 31-115 Kraków }\end{array}$ & $\begin{array}{l}\text { brak szczegółowych } \\
\text { danych }{ }^{169}\end{array}$ \\
\hline 144 & Kraków & $\begin{array}{l}\text { Muzeum Narodowe } \\
\text { al. 3 maja 1, 30-062 Kraków }\end{array}$ & $\begin{array}{l}\text { ponad 31 tysięcy } \\
\text { woluminów, w tym } \\
\text { inkunabuły } 170\end{array}$ \\
\hline $\begin{array}{l}\text { Kedagogiczna Biblioteka Wojewódzka } \\
\text { im. Hugona Kołłątaja } \\
\text { al. F. Focha 39, 30-119 Kraków }\end{array}$ & $\begin{array}{l}\text { szacunkowo około } \\
1700 \text { druków, w tym } \\
1 \text { inkunabuł, 62 dru- } \\
\text { ki z XVI wieku, } \\
165 \text { druków z XVII } \\
\text { wieku, 782 dru- } \\
\text { ków z XVIII wie- } \\
\text { ku, 31 druków } \\
\text { z XIX wieku oraz } \\
\text { około 657 dubletów } \\
\text { i defektów171 }\end{array}$ \\
\hline
\end{tabular}

167 Z. Bela, Wybrane starodruki w bibliotece Muzeum Farmacji Uniwersytetu Jagiellońskiego w Krakowie, ,Forum Bibliotek Medycznych” 8, 2015, nr 1 (15), s. 106, http://cybra.lodz. pl/Content/13732/download/; zob. też https://muzeumfarmacji.uj.edu.pl/ekspozycja/; M. Sołtysiak, K. Wierzbicka, op. cit., s. 91.

$168 \mathrm{http} / / / \mathrm{mnk}$.pl/wystawy/zbior-starych-drukow-i-rekopisow. Według M. Sołtysiak i K. Wierzbickiej (op. cit., s. 98) zbiory te w 1997 roku przedstawiały się następująco: „Zbiory Starych Druków i Rękopisów - księgozbiory polskich rodów magnackich, uczonych i kolekcjonerów, ogółem 140 inkunabułów i ponad 20000 starodruków". Zob. też F. Kopera, Spis druków epoki Jagiellońskiej w zbiorze Emeryka hrabiego Hutten-Czapskiego w Krakowie, Kraków 1900.

169 Muzea Kościoła katolickiego..., s. 56.

170 Zbiór ten podzielony jest chronologicznie na druki XV, XVI, XVII, XVIII i XIX wieku. Wydzielono także panegiryki, kalendarze, czasopisma i muzykalia — zob. http://mnk.pl/dzial-starych-drukow-i-rekopisow.

171 Dane na podstawie wystąpienia Agnieszki Fludy-Krokos Skąd się wzięty stare druki w Pedagogicznej Bibliotece Wojewódzkiej w Krakowie - studium proweniencyjne, wygłoszonego podczas „III Spotkania Proweniencyjnej Grupy Roboczej” (Wrocław 12.10.2018). Według https:// www.pbw.edu.pl/o-bibliotece/zbiory/starodruki-w-pbw w bibliotece znajduje się 1898 starych druków, 1 inkunabuł, około 40 druków z XVI wieku oraz ponad 100 druków z XVII wieku. Z kolei L. Kurowska-Trudzik (Biblioteki pedagogiczne jako centra informacji edukacyjnej, „Biuletyn EBIB” 2009, nr 6 (106), sierpień/wrzesień, http://www.ebib.pl/2009/106/a.php?kurowska) podaje, że biblioteka posiada około 2 tysiące starych druków.

\section{ROCZNIKI BIBLIOTECZNE}

ROK LXIII, 2019

(C) for this edition by CNS 


\begin{tabular}{|c|c|c|c|}
\hline 145 & Kraków & $\begin{array}{l}\text { Sanktuarium św. Michała Archanioła } \\
\text { i bł. Bronisława Markiewicza } \\
\text { ul. ks. B. Markiewicza 25A, } \\
\text { 38-430 Miejsce Piastowe }\end{array}$ & $\begin{array}{l}\text { brak szczegółowych } \\
\text { danych }^{172}\end{array}$ \\
\hline 146 & Kraków & $\begin{array}{l}\text { Wyższe Seminarium Duchowne Archidiecezji } \\
\text { Krakowskiej [dawniej: Biblioteka Papieskiej } \\
\text { Akademii Teologicznej] } \\
\text { ul. Podzamcze 8, 31-003 Kraków }\end{array}$ & $\begin{array}{l}\text { około } 5090 \text { wo- } \\
\text { luminów, w tym } \\
90 \text { woluminów inku- } \\
\text { nabułów }^{173}\end{array}$ \\
\hline$\{146\}$ & $\{$ Kraków\} & $\begin{array}{l}\text { \{Zgromadzenie Sióstr Kanoniczek Ducha } \\
\text { Świętego de Saxia } \\
\text { ul. Szpitalna 10, 31-024 Kraków\} }\end{array}$ & $\begin{array}{l}\text { \{brak szczegóło- } \\
\text { wych danych }\end{array}$ \\
\hline 147 & Krasnobród & $\begin{array}{l}\text { Muzeum Sakralne } \\
\text { ul. Tomaszowska 18, 22-440 Krasnobród }\end{array}$ & $\begin{array}{l}\text { brak szczegółowych } \\
\text { danych }{ }^{174}\end{array}$ \\
\hline 148 & Krasnystaw & $\begin{array}{l}\text { Muzeum Regionalne } \\
\text { ul. Piłsudskiego 5A, 22-300 Krasnystaw }\end{array}$ & $\begin{array}{l}\text { brak szczegółowych } \\
\text { danych }^{175}\end{array}$ \\
\hline 149 & Krośniewice & $\begin{array}{l}\text { Muzeum im. Jerzego Dunin-Borkowskiego } \\
\text { (oddział Muzeum Narodowego w Warszawie) } \\
\text { pl. Wolności 1, 99-340 Krośniewice }\end{array}$ & $\begin{array}{l}\text { brak szczegółowych } \\
\text { danych }^{176}\end{array}$ \\
\hline 150 & Krzeszów & $\begin{array}{l}\text { Opactwo Benedyktynek (Biblioteka) } \\
\text { pl. Jana Pawła II 5, 58-405 Krzeszów }\end{array}$ & 353 woluminy ${ }^{177}$ \\
\hline
\end{tabular}

172 Zob. R. Kucharska, Polskie starodruki w Bibliotece Zgromadzenia św. Michała Archanioła w Miejscu Piastowym (praca magisterska), Akademia Pedagogiczna im. Komisji Edukacji Narodowej, Kraków 2002.

173 Biblioteki Kościoła Katolickiego..., s. 52.

174 Muzea Kościoła katolickiego..., s. 62-63; https://www.krasnobrod-sanktuarium.pl/muzeum-sakralne/starodruki/.

175 Zob. M. Sołtysiak, K. Wierzbicka, op. cit., s. 104; http://www.muzeumkrasnystaw.webd. $\mathrm{pl} /$ index.php?option $=$ com_content $\&$ view $=$ article $\& \mathrm{id}=60 \&$ Itemid $=58 ; \mathrm{https}: / /$ krasnystaw.naszemiasto.pl/imprezy/wystawa-quot-historia-krasnegostawu-i-okolic-xiv-xx-w-quot-875544.html.

176 Według http://powiatkutno.eu/dokumenty/turystyka/Muzeum\%20LKROSNIEWICE.pdf znajduje się tam „wielotysięczny księgozbiór z kilkoma inkunabułami i kilkuset starodrukami”.

177 Biblioteki Kościoła Katolickiego..., s. 219; http://benedyktynki-krzeszow.pl/lwowski-ksiegozbior-benedyktynek. W 1995 roku stan zbiorów starodrucznych miał wynosić 292 tytuły; por. A. Faber-Chojnacka, Dzieje szkoty i biblioteki Panien Benedyktynek lwowskich (na podstawie kronik klasztornych, [w:] Lwów: Miasto, społeczeństwo, kultura, Kraków 1995, s. 41-42, http://rep. up.krakow.pl/xmlui/bitstream/handle/11716/2725/03_dzieje_szkoly_i_biblioteki_a_faber_chojnacka.pdf?sequence=1\&isAllowed=y. Według A. Kowalskiej ze Lwowa do Krzeszowa po II wojnie światowej przewieziono 586 starych druków - eadem, Biblioteka klasztoru panien Benedyktynek Łacińskich w Krzeszowie w latach 1946-2000, „Saeculum Christianum. Pismo historyczno-społeczne" 20,2013, s. 235, http://bazhum.muzhp.pl/media//files/Saeculum_Christianum_pismo_historyczne/Saeculum_Christianum_pismo_historyczne-r2013-t20/Saeculum_Christianum_pismo_historyczne-r2013-t20-s233-249/Saeculum_Christianum_pismo_historyczne-r2013-t20-s233-249.pdf. Zob. też J. Gwioździk, Biblioteka Panien Benedyktynek łacińskich we Lwowie (XVI-XVIII wiek), Katowice 2001; http://www.zkpis.umk.pl/?w-opactwie-siostr-benedyktynek-w-krzeszowie,226; http://www.zkpis.umk.pl/?w-opactwie-siostr-benedyktynek-w-krzeszowie,250; http://www.zkpis. umk.pl/?w-opactwie-siostr-benedyktynek-w-krzeszowie, 215.

\section{ROCZNIKI BIBLIOTECZNE}

ROK LXIII, 2019

(C) for this edition by CNS 


\begin{tabular}{|c|c|c|c|}
\hline 151 & Kwidzyn & $\begin{array}{l}\text { Biblioteka Miejsko-Powiatowa } \\
\text { ul. Kościuszki 54, 82-500 Kwidzyn }\end{array}$ & $\begin{array}{l}\text { brak szczegółowych } \\
\text { danych }{ }^{178}\end{array}$ \\
\hline 152 & Ląd & $\begin{array}{l}\text { Biblioteka Wyższego Seminarium Duchownego } \\
\text { Towarzystwa Salezjańskiego } \\
\text { Ląd nad Wartą 101, 62-406 Lądek }\end{array}$ & $\begin{array}{l}290 \text { woluminów, } \\
\text { w tym } 2 \text { woluminy } \\
\text { inkunabułów } \\
\text { (stan na } 2011 \text { rok) }^{179}\end{array}$ \\
\hline 153 & Legnica & $\begin{array}{l}\text { Legnicka Biblioteka Publiczna } \\
\text { ul. Piastowska 22, 59-220 Legnica }\end{array}$ & 1 wolumin $^{180}$ \\
\hline 154 & Legnica & $\begin{array}{l}\text { Biblioteka Wyższego Seminarium Duchownego } \\
\text { Diecezji Legnickiej } \\
\text { ul. Jana Pawła II 1, 59-220 Legnica }\end{array}$ & 715 woluminów ${ }^{181}$ \\
\hline 155 & Leszno & $\begin{array}{l}\text { Archiwum Państwowe (Biblioteka) } \\
\text { ul. Ludwika Solskiego 71, 64-100 Leszno }\end{array}$ & $\begin{array}{l}\text { brak szczegółowych } \\
\text { danych }^{182}\end{array}$ \\
\hline 156 & Leszno & $\begin{array}{l}\text { Biblioteka Publiczna Miejska im. Stanisława } \\
\text { Grochowiaka } \\
\text { ul. Bolesława Chrobrego 3, 64-100 Leszno }\end{array}$ & 32 woluminy ${ }^{183}$ \\
\hline 157 & Leszno & $\begin{array}{l}\text { Muzeum Okręgowe (Biblioteka) } \\
\text { pl. J. Metziga 17, 64-100 Leszno }\end{array}$ & $\begin{array}{l}418 \text { druków } \\
\text { (stan na } 2001 \text { rok) }^{184}\end{array}$ \\
\hline 158 & Leżajsk & $\begin{array}{l}\text { Klasztor Ojców Bernardynów (Biblioteka) } \\
\text { pl. Mariacki 8, 37-300 Leżajsk }\end{array}$ & $\begin{array}{l}5690 \text { woluminów } \\
\text { (stan na } 2005 \text { rok) }\end{array}$ \\
\hline
\end{tabular}

178 https://www.portalpomorza.pl/wiadomosci/32990,kodeks-wrocil-do-kwidzyna.

179 M. Babicz, Biblioteka w Ladzie w latach 1921-2011, [w:] Salezjanie w Ladzie 1921-2011, red. J. Nowiński, Warszawa-Ląd 2011, s. 128. Według Bibliotek Kościoła Katolickiego... (s. 172) w 2005 roku w zbiorach tych znajdowało się 275 woluminów starych druków, w tym 2 woluminy inkunabułów. Zob. też S. Kosiński, Dwadzieścia pięć lat Wyższego Seminarium Towarzystwa Salezjańskiego w Lązie n. Warta 1952-1977, „Seminare. Poszukiwania Naukowe” 3, 1978, s. 14, http:// bazhum.muzhp.pl/media//files/Seminare_Poszukiwania_naukowe/Seminare_Poszukiwania_naukowe-r1978-t3/Seminare_Poszukiwania_naukowe-r1978-t3-s7-35/Seminare_Poszukiwania_naukowe-r1978-t3-s7-35.pdf; M. Babicz, Stare druki biblioteki Wyższego Seminarium Duchownego Towarzystwa Salezjańskiego w Lądzie nad Warta. Katalog, t. I-III (praca dyplomowa), Ląd 1992; idem, Stare druki biblioteki Wyższego Seminarium Duchownego Towarzystwa Salezjańskiego w Ladzie nad Warta, „Archiwa, Biblioteki i Muzea Kościelne” 80, 2003, s. 17-27; idem, Biblioteka Cystersów w Ladzie nad Warta od XII do XIX wieku, t. I-III (praca doktorska), Uniwersytet Kardynała Stefana Wyszyńskiego w Warszawie, Warszawa 2019; http://wsdts.pl/biblioteka/.

${ }^{180}$ Dane na podstawie kwerendy M. Kycler.

181 Biblioteki Kościoła Katolickiego..., s. 94; http://www.biblioteka.diecezja.legnica.pl/historia-4.

182 Zob. http://archiwum.leszno.pl/biblioteka/.

183 Dane na podstawie kwerendy M. Kycler.

184 K. Szymańska, Katalog starych druków Muzeum Okręgowego w Lesznie, Leszno 2001, s. 5; M. Sołtysiak, K. Wierzbicka, op. cit., s. 111.

185 Biblioteki Kościoła Katolickiego..., s. 187. Według https://nowiny24.pl/99letni-kustosz-pilnuje-ksiegozbioru-w-klasztornej-bibliotece-w-lezajsku/ar/5810537 w 2015 roku w zbiorach tych znajdowało się 2650 starych druków. Z kolei https://pl.wikipedia.org/wiki/Zesp\%C3\%B3\%C5\%82_ Ko\%C5\%9Bcio\%C5\%82a_i_Klasztoru_Bernardyn\%C3\%B3w_w_Le\%C5\%BCajsku podaje, że 


\begin{tabular}{|c|c|c|c|}
\hline 159 & Leżajsk & $\begin{array}{l}\text { Muzeum Ziemi Leżajskiej } \\
\text { ul. Mickiewicza 20A, 37-300 Leżajsk }\end{array}$ & $\begin{array}{l}\text { brak szczegółowych } \\
\text { danych }\end{array}$ \\
\hline 160 & Licheń Stary & $\begin{array}{l}\text { Muzeum im. ks. Józefa Jarzębowskiego } \\
\text { (Skarbczyk Starej Książki) } \\
\text { ul. Klasztorna 4, 62-563 Licheń Stary }\end{array}$ & $\begin{array}{l}320 \text { druków (w tym } \\
\text { inkunabuły) (stan na } \\
2000 \text { rok) }\end{array}$ \\
\hline 161 & Lubań & $\begin{array}{l}\text { Muzeum Regionalne } \\
\text { Rynek-Ratusz, 59-800 Lubań }\end{array}$ & $\begin{array}{l}\text { co najmniej } 24 \text { dru- } \\
\mathrm{ki}^{188}\end{array}$ \\
\hline 162 & Lubiń & $\begin{array}{l}\text { Opactwo Benedyktynów } \\
\text { ul. Mickiewicza 6, 64-010 Lubiń }\end{array}$ & $\begin{array}{l}\text { brak szczegółowych } \\
\text { danych }{ }^{189}\end{array}$ \\
\hline 163 & Lublin ${ }^{190}$ & $\begin{array}{l}\text { Archiwum Państwowe (Biblioteka) } \\
\text { ul. Jezuicka 13, 20-400 Lublin }\end{array}$ & $\begin{array}{l}235 \text { druki } \\
\text { (stan na luty } \\
2014 \text { roku) }\end{array}$ \\
\hline 164 & Lublin & $\begin{array}{l}\text { Biblioteka Klasztoru Karmelitów Bosych } \\
\text { ul. Świętoduska 14, 20-082 Lublin }\end{array}$ & 1164 woluminy ${ }^{192}$ \\
\hline 165 & Lublin & $\begin{array}{l}\text { Biblioteka Metropolitalnego Seminarium Du- } \\
\text { chownego [wcześniej: Muzeum Starodruków } \\
\text { i Sztuki Sakralnej] } \\
\text { ul. Prymasa Stefana Wyszyńskiego 6, } \\
\text { 20-001 Lublin }\end{array}$ & $\begin{array}{l}17989 \text { druków, } \\
\text { w tym } 256 \text { inkuna- } \\
\text { bułów }^{193}\end{array}$ \\
\hline
\end{tabular}

stan zbiorów wynosi „około 4000 starodruków”. Zob. też Muzea Kościoła katolickiego..., s. 67; Z. Larendowicz, Biblioteka klasztoru Ojców Bernardynów w Leżajsku (maszynopis), Leżajsk 1999, za: Biblioteki Kościoła Katolickiego..., s. 187.

186 Zob. http://muzeum-lezajsk.pl/biblioteka/; https://fakty.interia.pl/podkarpackie/news-cenny-dar-dla-muzeum-ziemi-lezajskiej,nId,1247313.

187 http://www.lichen.pl/pl/192/historia_kolekcji; http://www.lichen.pl/pl/188/muzeum_im._ ks._j. jarzebowskiego.

188 Mowa tu o drukach wydanych w Wittenberdze w latach 1534-1541 — zob. https://www. eluban.pl/wiadomosci/20699,zaginione-skarby-wracaja-do-lubania.

189 Według https://zabytek.pl/pl/obiekty/lubin-zespol-opactwa-benedyktynow-33 w klasztornej bibliotece do dziś ,,przechowywane są zbiory inkunabułów i starodruków”. Zob. też J. Ostrowski, Bibljoteka Klasztoru Benedyktynów w Lubiniu, Poznań 1929, s. 11 — autor podaje, że w 1929 roku w zbiorach tych znajdowało się 56 poloników z XVI wieku oraz 13 inkunabułów.

190 Zob. Lublin a ksiązka, red. A. Krawczyk, E. Józefowicz-Wisińska, Lublin 2004.

191 B. Dymitrzak, Biblioteka w Archiwum, „APLA - Biuletyn” 2014, nr 1 (11), s. 19-21, https://issuu.com/ap_lublin/docs/numer11.

192 Biblioteki Kościoła Katolickiego..., s. 155. Zob. też M. Stopa, Oprawy starodruków XVI-wiecznych $w$ zbiorach biblioteki oo. karmelitów bosych $w$ Lublinie (praca magisterska), Uniwersytet Marii Curie-Skłodowskiej, Lublin 2008; J. Łuszczyk, Oprawy na XVII-wiecznych starodrukach $w$ bibliotece oo. karmelitów bosych $w$ Lublinie (praca magisterska), Uniwersytet Marii Curie-Skłodowskiej, Lublin 2008; K. Ślusarczyk, Proweniencja starodruków z XVII wieku w Bibliotece oo. Karmelitów Bosych w Lublinie (praca magisterska), Uniwersytet Marii Curie-Skłodowskiej, Lublin 2008; http://karmel.lublin.pl/base.php?id=5/historia.2.

193 Biblioteki Kościoła Katolickiego..., s. 95. Według https://lublin.gosc.pl/doc/1842373. Nowe-muzeum-w-Lublinie liczba inkunabułów w 2014 roku miała wynosić 175 tytuły. Zob. też B. Jawor, Inkunabuły w Bibliotece Kanoników regularnych w Kraśniku (praca magisterska), Uni- 


\begin{tabular}{|c|l|l|l|}
\hline 166 & Lublin & $\begin{array}{l}\text { Biblioteka Uniwersytecka Katolickiego } \\
\text { Uniwersytetu Lubelskiego } \\
\text { (Oddział Zbiorów Specjalnych — Sekcja } \\
\text { Starych Druków) } \\
\text { ul. Chopina 27, 20-023 Lublin }\end{array}$ & $\begin{array}{l}\text { 50 928 woluminów, } \\
\text { w tym 139 wolumi- } \\
\text { nów inkunabułów } \\
\text { (stan na 2005 rok) }\end{array}$ \\
\hline 167 & Lublin & $\begin{array}{l}\text { Biblioteka Uniwersytetu Marii Curie-Skłodow- } \\
\text { skiej (Pracownia Starodruków i Rękopisów) } \\
\text { ul. I. Radziszewskiego 11, 20-031 Lublin }\end{array}$ & $\begin{array}{l}19248 \text { woluminów, } \\
\text { wym 4 inkunabu- } \\
\text { ły } 195\end{array}$ \\
\hline 168 & Lublin & $\begin{array}{l}\text { Biblioteka Wyższego Seminarium Duchownego } \\
\text { Księży Marianów } \\
\text { ul. Bazylianówka 54B, 20-160 Lublin }\end{array}$ & $\begin{array}{l}\text { 2074 woluminy, } \\
\text { w tym 34 woluminy } \\
\text { inkunabułów } 196\end{array}$ \\
\hline
\end{tabular}

wersytet Marii Curie-Skłodowskiej, Lublin 1986; H. Rokicka, Paradyski inkunabut - sygnatura Inc. 9, 10, 11 z Biblioteki Seminarium Duchownego w Lublinie: analiza inkunabulistyczna (praca magisterska), Uniwersytet Marii Curie-Skłodowskiej, Lublin 1995; J. Ziółkowska, Inkunabuły Biblioteki Wyższego Metropolitalnego Seminarium Duchownego w Lublinie w świetle Centralnego Katalogu Inkunabułów (praca licencjacka), Uniwersytet Mikołaja Kopernika, Toruń 2003.

194 Biblioteki Kościoła Katolickiego..., s. 40; B. Zezula, Biblioteka Uniwersytecka KUL wczoraj i dziś, „Fides: Biuletyn Bibliotek Kościelnych” 22, 2016, nr 1, s. 7, http://digital.fides.org.pl/dlibra/ docmetadata?id=1760; http://www.bu.kul.pl/stare-druki-xvi-xviii-w-w-zbiorach-biblioteki-uniwersyteckiej-kul-wstep-i-wprowadzenie,art_10846.html; zob. tam całe opracowanie dotyczące starych druków w KUL mgr Małgorzaty Trojnackiej. W 2015 roku biblioteka wzbogaciła się o 6 starych druków z XVII wieku — zob. http://lublin.wyborcza.pl/lublin/1,48724,19247005,cenne-starodruki-dla-biblioteki-kul-dar-kolekcjonera.html. Zob. też J. Wasilewska, Oprawy inkunabułów wydrukowanych w Wenecji w zbiorach Biblioteki KUL (praca magisterska), Katolicki Uniwersytet Lubelski, Lublin 1994; M. Trojnacka, Znaki wtasnościowe w starych drukach lubelskich (XVII-XVIII w.) w BU KUL, [w:] Lublin a ksiażka, cz. 2. Centrum i peryferie. Materiały z konferencji naukowej z okazji 35-lecia studiów bibliotekoznawczych na Uniwersytecie Marii Curie-Sktodowskiej, red. A. Krawczyk, Lublin 2011, s. 37-58; eadem, Stare druki z drukarni bazylianów wileńskich w zbiorach Biblioteki Uniwersyteckiej Katolickiego Uniwersytetu Lubelskiego, [w:] Związi Lublina i Wilna. Studia i materiały, red. T. Rodziewicz, Lublin 2012, s. 303-328.

195 W ramach tego zbioru wyróżniono również druki krakowskie z XVI wieku (23 dzieła) — zob. https://www.umcs.pl/pl/starodruki.htm. Zob. też W. Gmiterek, Starodruki zamojskie w zbiorach Biblioteki Głównej UMSC w Lublinie, „Folia Bibliologica 1995” 38-39, 1990-1991, s. $117-122$.

196 Biblioteki Kościoła Katolickiego..., s. 156. Według J. Ptaka (Użytkownik zostawia ślad... Odręczne zapiski w starodrukach Biblioteki Księży Marianów, „Folia Bibliologica” 4849, 2006-2007, s. 41, http://dlibra.umcs.lublin.pl/dlibra/docmetadata?id=19610\&from=publicat ion) księgozbiór ten liczy ponad 2 tysiące pozycji. Zob. też https://www.dziennikwschodni.pl/ lublin/byly-zakonnik-kradl-cenne-ksiegi-z-seminarium-robilem-to-z-zemsty,n,1000013282.html; M. Mikulska-Gurdziel, Nicolaus Perottus: Cornu Copiae Linguae Latinae ed. Aldus Manutius. Venezia 1499 - Sygnatura XV. 12 z biblioteki Seminarium Duchownego Księży Marianów w Lublinie: analiza inkunabulistyczna (praca magisterska), Uniwersytet Marii Curie-Skłodowskiej, Lublin 1999; A. Bartczak, Szesnastowieczne oprawy ślepo tłoczone i złocone starodruków ze zbiorów Biblioteki Braci Marianów w Lublinie (praca magisterska), Uniwersytet Marii Curie-Skłodowskiej, Lublin 2002; A. Wasil, Orationes ed. Philippus Beroaldus-Janus Cardo Bononiensis: Ciceronis Adversus Valerium Oratio. Bologna, Ben Hectoris Faelli, 13 IV 1499. Sygnatura XV. 20 z Biblioteki Seminarium Duchownego Księży Marianów w Lublinie: analiza inkunabulistyczna (praca magi- 


\begin{tabular}{|c|c|c|c|}
\hline 169 & Lublin & $\begin{array}{l}\text { Wojewódzka Biblioteka Publiczna } \\
\text { im. Hieronima Łopacińskiego } \\
\text { ul. Narutowicza 4, 20-950 Lublin }\end{array}$ & 11898 druków 197 \\
\hline 170 & Lubomierz & $\begin{array}{l}\text { Klasztor Sióstr Benedyktynek } \\
\text { pl. Kościelny 1, 59-623 Lubomierz }\end{array}$ & $\begin{array}{l}\text { brak szczegółowych } \\
\text { danych }{ }^{198}\end{array}$ \\
\hline 171 & Lańcut & $\begin{array}{l}\text { Biblioteka Muzeum-Zamek/Biblioteka Poto- } \\
\text { ckich w Łańcucie } \\
\text { ul. Zamkowa 1, 37-100 Łańcut }\end{array}$ & $\begin{array}{l}1194 \text { druków, } \\
\text { w } 1773 \text { woluminy } \\
\text { (stan na } 1974 \text { rok) }^{199}\end{array}$ \\
\hline 172 & Łask & $\begin{array}{l}\text { Muzeum parafialne w kolegiacie Łaskiej } \\
\text { (oddział Muzeum Archidiecezji Łódzkiej) } \\
\text { ul. Warszawska 15, 98-100 Łask }\end{array}$ & $\begin{array}{l}\text { brak szczegółowych } \\
\text { danych }\end{array}$ \\
\hline 173 & Łomża & $\begin{array}{l}\text { Biblioteka Wyższego Seminarium Duchownego } \\
\text { Diecezji Łomżyńskiej } \\
\text { pl. Jana Pawła II, 18-400 Łomża }\end{array}$ & $\begin{array}{l}\text { brak szczegółowych } \\
\text { danych }^{201}\end{array}$ \\
\hline 174 & Łomża & $\begin{array}{l}\text { Łomżyńskie Towarzystwo Naukowe } \\
\text { im. Wagów } \\
\text { ul. Długa } 13,18-400 \text { Łomża }\end{array}$ & $\begin{array}{l}\text { brak szczegółowych } \\
\text { danych }^{202}\end{array}$ \\
\hline
\end{tabular}

sterska), Uniwersytet Marii Curie-Skłodowskiej, Lublin 2002; M. Stachyra, Starodruki Biblioteki Ojców Reformatów w Warszawie przechowywane w Bibliotece Ojców Marianów w Lublinie (praca magisterska), Uniwersytet Marii Curie-Skłodowskiej, Lublin 2004.

197 http://hl.wbp.lublin.pl/wbp/index.php/zbiory/zbiory-specjalne.html. Zob. też A. Dziuba, Katalogi Działu Zbiorów Specjalnych Wojewódzkiej Biblioteki Publicznej im. H. Łopacińskiego w Lublinie, „Bibliotekarz Lubelski” 127, 1996, s. 48-55; I. Dziok-Strelnik, Bibliografia starych druków lubelskich 1630-1800, Lublin 1998; J. Smolarz, Zbiory specjalne Biblioteki im. H. Łopacińskiego w Lublinie, „Bibliotekarz Lubelski” 43, 2000, s. 75-104; I.M. Kozłowska, Starodruki z biblioteki oo. Dominikanów z Wilna w Bibliotece im. H. Łopacińskiego w Lublinie (praca magisterska), Uniwersytet Marii Curie-Skłodowskiej, Lublin 1999; A. Myrcha, Starodruki oo. reformatów z Chełma w zbiorach Biblioteki im. H. Łopacińskiego (praca magisterska), Uniwersytet Marii Curie-Skłodowskiej, Lublin 1999.

198 Zob. http://niedziela.pl/artykul/124582/nd/Cenny-relikwiarz-i-starodruki.

199 Z. Wiśniowska, Katalog starych druków Biblioteki Muzeum-Zamku w Łańcucie, Łańcut 1974, s. VIII. W ramach tych zbiorów z kolekcji Mikołaja Potockiego pochodzi 715 druków, w tym 1 inkunabuł (zob. http://www.bu.kul.pl/lancut,art_10370.htm), a z kolekcji Izabeli z Czartoryskich Lubomirskiej - 18 druków (zob. http://www.zamek-lancut.pl/muzykalia/strony/biblioteka-lancucka). Według https://www.zamek-lancut.pl/pl/ZamekDzisiaj w bibliotece znajduje się obecnie 300 woluminów starych druków cyrylickich. W katalogu wydanym w 1994 roku w zbiorze tym odnotowano 109 pozycji — zob. Katalog starodruków cyrylickich Muzeum Zamku w Lańcucie, oprac. W. Witkowski, Kraków 1994.

200 Muzea Kościoła katolickiego..., s. 79; https://archidiecezja.lodz.pl/muzeum/linki.htm.

201 Biblioteki Kościoła Katolickiego..., s. 100: „stare druki nie są skatalogowane”. Zob. też K. Pruszyński, Biblioteka Wyższego Seminarium Duchownego w Łomży w roku 2000, [w:] Księga Jubileuszowa Wyższego Seminarium Duchownego w Lomży (1919-2000), red. J. Sokołowski, Łomża 2000, s. 205-207.

202 Według http://ltn2.nazwa.pl/wp/biblioteka-ltn/ księgozbiór biblioteki to „w przeważającej części starodruki i książki XIX-wieczne". Z kolei na stronach https://archiwa.org/archiw a/\%C5\%82om $\% \mathrm{C} 5 \% \mathrm{BCy} \% \mathrm{C} 5 \% 84$ skie-towarzystwo-naukowe-im-wag\% $\% 3 \% \mathrm{~B} 3 \mathrm{w}$ oraz https:// 


\begin{tabular}{|c|l|l|l|}
\hline 175 & Łomża & $\begin{array}{l}\text { Muzeum Diecezjalne } \\
\text { ul. Giełczyńska 20A, 18-400 Łomża }\end{array}$ & $\begin{array}{l}\text { brak szczegółowych } \\
\text { danych }\end{array}$ \\
\hline$\{175\}$ & $\{$ Łomża $\}$ & $\begin{array}{l}\{\text { Opactwo Benedyktynek } \\
\text { ul. Dworna 32, 18-400 Łomża }\}\end{array}$ & $\begin{array}{l}\text { \{brak szczegóło- } \\
\left.\text { wych danych }^{204}\right\}\end{array}$ \\
\hline 176 & Łowicz & $\begin{array}{l}\text { Archiwum i Biblioteka Kapituły Katedralnej } \\
\text { Diecezji Łowickiej } \\
\text { Stary Rynek 19A, 99-400 Łowicz }\end{array}$ & $\begin{array}{l}\text { około 3450 druków, } \\
\text { w tym } 80 \text { inkunabu- } \\
\text { łów }^{205}\end{array}$ \\
\hline 177 & Łowicz & $\begin{array}{l}\text { Klasztor Sióstr Bernardynek } \\
\text { al. Sienkiewicza 15, 99-400 Łowicz }\end{array}$ & ponad 6 druków ${ }^{206}$ \\
\hline 178 & Łowicz & $\begin{array}{l}\text { Muzeum w Łowiczu (Biblioteka) } \\
\text { Stary Rynek 5/7, 99-400 Łowicz }\end{array}$ & $\begin{array}{l}\text { brak szczegółowych } \\
\text { danych }\end{array}$ \\
\hline 179 & Łódź & $\begin{array}{l}\text { Archiwum Państwowe (Biblioteka) } \\
\text { pl. Wolności 1, 91-415 Łódź }\end{array}$ & 220 druków $^{208}$ \\
\hline
\end{tabular}

pl.wikipedia.org/wiki/\%C5\%810m\%C5\%BCy\%C5\%84skie_Towarzystwo_Naukowe_im. Wag\%C3\%B3w znajdziemy informację, że ,starodruki oraz wydawnictwa z XIX i początku XX̄ wieku stanowią $30 \%$ zasobu".

203 Muzeum ma posiadać między innymi graduał krakowski z 1641 roku oraz komentarz do Ewangelii wydany w Moguncji w 1602 roku — zob. https://kz1.pl/4755/muzea-w-wojewodztwie-podlaskim; https://pl.wikipedia.org/wiki/Muzeum_Diecezjalne_w_\%C5\%81om\%C5\%BCy.

204 Zob. https://4lomza.pl/index.php?wiad $=15 \overline{4} 11$.

205 S. Majkut podaje, że liczba zbiorów biblioteki (przechowującej rękopisy, inkunabuły i starodruki) liczy ponad 3500 egzemplarzy (w tym druki z biblioteki biskupa Łukasza Watzenrode oraz 800 ksiąg z biblioteki arcybiskupa gnieźnieńskiego Ignacego Krasickiego, Prymasa Polski). Z kolei z opracowania T. Makowskiego dowiadujemy się, że tamtejsze zbiory rękopisów to 60 jednostek. Łącząc przytoczone informacje możemy zatem otrzymać szacunkową liczbę zbiorów starych druków wynoszącą około 3450 egzemplarzy. Zob. S. Majkut, Obiekty sakralne Diecezji Łowickiej - przeglad dokonań konserwatorskich, [w:] Konferencja Krajowa „Potrzeby Konserwatorskie Obiektów Sakralnych na przykładzie makroregionu tódzkiego" Łódź, 9-10 grudnia 2005 r., s. 70, http://thermo.p.lodz.pl/sacrum/pdfs/art_08.pdf; Rękopisy w zbiorach kościelnych, oprac. T. Makowski przy współpracy P. Sapały [„,Zbiory Rękopisów w Polsce”, T. 2], Warszawa 2014, s. 242. Zob. też https://diecezja.lowicz.pl/historia/; A. Owczarek-Cichowska, Inwentarz Biblioteki Kapitulnej w Łowiczu z XVIII wieku, Łowicz 1993, https://books.google.pl/books/about/ Inwentarz_Biblioteki_Kapitulnej_w_\%C5\%81owic.html?id=BEsvAQAAIAAJ\&redir_esc=y; Z. Skiełczyński, Superekslibrisy z Biblioteki Kapitulnej w Łowiczu, „Studia Theologica Varsaviensia" 28, 1990, nr 1, s. 243-259, http://bazhum.muzhp.pl/media//files/Studia_Theologica_Varsaviensia/Studia_Theologica_Varsaviensia-r1990-t28-n1/Studia_Theologica_Varsaviensia-r1990-t28-n1-s243-259/Studia_Theologica_Varsaviensia-r1990-t28-n1-s243-259.pdf; Z. Modrzewska, Katalog drukowanych zarzadzen pruskich z lat 1766-1809 przechowywanych w Bibliotece Kapitulnej w Łowiczu (praca magisterska), Uniwersytet Łódzki, Łódź 1983.

206 http://www.bernardynki.lowicz.opoka.org.pl/tekst/sa8.html.

207 Wiadomo, że w muzeum znajduje się „,cenny zbiór starodruków, począwszy od XVI w., pochodzących ze zbiorów: Władysława Tarczyńskiego, Romualda Oczykowskiego, Emila Balcera i Muzeum Polskiego w Rapperswilu" — zob. http://muzeumlowicz.pl/biblioteka/.

${ }_{208}$ Zob. http://www.lodz.ap.gov.pl/art,51,starodruki-w-zbiorach-biblioteki-archiwum-panstwowego-w-lodzi; A. Lajdenfrost, Starodruki i cymelia z Archiwum Państwowego w Lodzi. Katalog, cz. 1, 


\begin{tabular}{|c|l|l|l|}
\hline 180 & Łódź & $\begin{array}{l}\text { Biblioteka im. prof. Jerzego Wróblewskiego } \\
\text { (Wydział Prawa i Administracji Uniwersytetu } \\
\text { Łódzkiego) } \\
\text { ul. Kopcińskiego 8/12, 90-232 Łódź }\end{array}$ & $\begin{array}{l}\text { brak szczegółowych } \\
\text { danych }\end{array}$ \\
\hline 181 & Łódź & $\begin{array}{l}\text { Biblioteka Instytutu Historii Uniwersytetu } \\
\text { Łódzkiego } \\
\text { ul. A. Kamińskiego 27A, 90-219 Łódź }\end{array}$ & $\begin{array}{l}\text { brak szczegółowych } \\
\text { danych }\end{array}$ \\
\hline 182 & Łódź & $\begin{array}{l}\text { Biblioteka Uniwersytetu Łódzkiego } \\
\text { (Czytelnia Zbiorów Specjalnych) } \\
\text { ul. Jana Matejki 32/38, 90-237 Łódź }\end{array}$ & $\begin{array}{l}\text { prawie 28 tysięcy } \\
\text { druków, w tym } \\
21 \text { inkunabułów } \\
\text { (w 23 wolumi- } \\
\text { nach) }\end{array}$ \\
\hline
\end{tabular}

„Rocznik Łódzki” 49, 2002, s. 195-268, zwł. s. 199; idem, Starodruki z Archiwum Państwowego w Łodzi. Katalog, cz. 2, „Rocznik Łódzki” 56, 2009, s. 196-237.

209 https://www.wpia.uni.lodz.pl/struktura/biblioteka.

210 Stare druki zostały wyodrębnione w ramach cymeliów biblioteki, liczących około 15 tysięcy woluminów druków zwartych - zob. http://www.historia.uni.lodz.pl/index.php/home/ biblioteka-instytutu-historii-ul.

211 Polonika stanowią jedną piątą zbioru; produkcja polska: około 2500 tytułów — zob. http://www.lib.uni.lodz.pl/?idx=Stare\%20Druki\&wew=profil. J. Andrzejewski (Zbiory specjalne w bibliotekach Łodzi, „Acta Universitatis Lodziensis. Folia Librorum” 3, 1992, s. 139) wspomina o 24 inkunabułach (w ramach BUŁ, Miejskiej Biblioteki Publicznej, Muzeum Sztuki, Biblioteki Państwowej Wyższej Szkoły Sztuk Plastycznych oraz Ośrodka Dokumentacji Zabytków). Według danych podanych przez J. Andrzejewskiego (ibidem, s. 138-140) w 1992 roku stan zbiorów starodrucznych wynosił około 30 tysięcy druków. Na s. 139 autor podaje również, że „Biblioteki Instytutu Historii i Wydziału Prawa UŁ posiadają starodruki [por. Sprawozdania Biblioteki Uniwersyteckiej w Łodzi 1945-1985/1986 - K.S.]”. Zob. też J. Cesak, Skrócony opis druków eksponowanych na wystawie [Starodruki medyczne w zbiorach tódzkich bibliotek naukowych], „Archiwum Historii Medycyny” 1982, z. 1-4, s. 96-100; J. Potemska, Polonika XVI-wieczne w ksiegozbiorze Biblioteki Uniwersyteckiej w Łodzi, „Listy Bibliofilskie” 1983, s. 43-48; A. Felchner, M. Dutkiewicz, M. Kuna, Starodruki medyczne w zbiorach bibliotek naukowych Łodzi, Łódź 1984; M. Polak, Stare druki, [w:] Zbiory i prace polonijne Biblioteki Uniwersyteckiej w Lodzi. Informator, Łódź 2000, s. 64-69; C. Hilmes, M. Kubisiak, Niemieckojęzyczna literatura podróżnicza osiemnastego wieku na podstawie zbiorów Biblioteki Uniwersyteckiej w Lodzi, „Folia Librorum” 2007, nr 14, s. [11]-26; M. Przybysz-Stawska, Zbiory specjalne na przyktadzie wybranych tódzkich bibliotek, [w:] Zbiory specjalne i regionalia w polskich bibliotekach naukowych i publicznych, red. R. Gaziński, Szczecin 2010, s. 138; D. Bartnik, Stare druki źródtem informacji kartograficznej o ziemiach polskich, [w:] Zbiory specjalne w bibliotekach polskich: problematyka badawcza i organizacyjna, red. A. Borysowska, Szczecin 2015, s. 119-130, https://zbc.ksiaznica.szczecin.pl/ dlibra/show-content/publication/35415?id=35415; P. Kowal, Polskie książki podróżnicze z okresu XVII i XVIII w. w zbiorach Sekcji Starych Druków Biblioteki Uniwersytetu Łódzkiego, [w:] Od przeszłości do teraźniejszości: Biblioteka Uniwersytetu Łódzkiego 1945-2015, red. M. Wrocławska, I. Kujawska, I. Łabiszewska, Łódź 2015, s. 297-310, http://repozytorium.uni.lodz.pl:8080/ xmlui/handle/11089/13179; P. Lewkowicz, Użytkowanie książki jako uruchomienie wahadła jej pamięci - wybrane przykłady wypożyczeń starych druków Biblioteki Uniwersytetu Łódzkiego, [w:] Biblioteka w czasie — czas w bibliotece, T. 1. Przez dzieje ku wspótczesności: materiaty konferencyjne, Lublin 25-26 września 2014, red. S. Wojnarowicz, B. Kasperek, Lublin 2015, s. 271-283; 


\begin{tabular}{|c|c|c|c|}
\hline 183 & Łódź & $\begin{array}{l}\text { Biblioteka Wyższego Seminarium Duchownego } \\
\text { Towarzystwa Salezjańskiego } \\
\text { ul. Wodna 36, 90-046 Łódź }\end{array}$ & $\begin{array}{l}\text { brak szczegółowych } \\
\text { danych }^{212}\end{array}$ \\
\hline 184 & Łódź & $\begin{array}{l}\text { Muzeum Archidiecezji Łódzkiej } \\
\text { (Dział książki zabytkowej) } \\
\text { ul. ks. I. Skorupki 13, 90-458 Łódź }\end{array}$ & $\begin{array}{l}350 \text { druków, w tym } \\
\text { inkunabuły } 213\end{array}$ \\
\hline$\{184\}$ & $\{$ Łódź\} & $\begin{array}{l}\text { \{Muzeum Historii Medycyny Uniwersytetu } \\
\text { Medycznego } \\
\text { ul. Żeligowskiego 7/9, 90-643 Łódź\} }\end{array}$ & $\begin{array}{l}\{\text { brak szczegóło- } \\
\left.\text { wych danych }^{214}\right\}\end{array}$ \\
\hline 185 & Łódź & $\begin{array}{l}\text { Pedagogiczna Biblioteka Wojewódzka } \\
\text { im. prof. Tadeusza Kotarbińskiego } \\
\text { ul. Wólczańska 202, 90-531 Łódź }\end{array}$ & 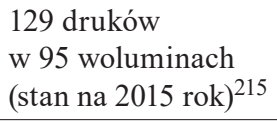 \\
\hline 186 & Łódź & $\begin{array}{l}\text { Wojewódzka Biblioteka Publiczna } \\
\text { im. Marszałka Józefa Piłsudskiego } \\
\text { ul. Gdańska 100/102, 90-508 Łódź }\end{array}$ & $\begin{array}{l}3500 \text { druków } \\
(\text { stan na } 1992 \text { rok) })^{216}\end{array}$ \\
\hline 187 & Łódź & $\begin{array}{l}\text { Wyższe Seminarium Duchowne Ojców } \\
\text { Franciszkanów [wcześniej: Biblioteka } \\
\text { Prowincjalna Ojców Franciszkanów } \\
\text { (przeniesiona z Warszawy w } 1986 \text { roku)] } \\
\text { ul. Okólna 185, 91-520 Łódź-Łagiewniki }\end{array}$ & $\begin{array}{l}\text { brak szczegółowych } \\
\text { danych }\end{array}$ \\
\hline 188 & Malbork & $\begin{array}{l}\text { Archiwum Państwowe } \\
\text { ul. Starościńska 1, 82-200 Malbork }\end{array}$ & $\begin{array}{l}\text { brak szczegółowych } \\
\text { danych }{ }^{217}\end{array}$ \\
\hline
\end{tabular}

M. Sulejewicz-Nowicka, Gromadzenie rzadkich wydawnictw XIX- $i$ XX-wiecznych oraz druków przeznaczonych do zbiorów specjalnych w latach 2005-2012 w BUt, [w:] Od przeszłości do teraźniejszości..., s. 179-199.

212 Biblioteki Kościoła Katolickiego..., s. 174: „stare druki [...] nie skatalogowane”.

213 Według Muzeów Kościoła katolickiego... (s. 83) w 2004 roku zbiory te były jedynie częściowo zinwentaryzowane. Zob. też https://archidiecezja.lodz.pl/muzeum/zbiory.htm; M. Sołtysiak, K. Wierzbicka, op. cit., s. 126; oraz M. Przybysz-Stawska, Biblioteka Wyższego Seminarium Duchownego w Łodzi: Wybrane zagadnienia, „Przegląd Biblioteczny” 2013, z. 4, s. 492: „W II połowie lat 90. XX w. biblioteka przekazała »białe kruki« (m.in. starodruki) do Muzeum Archidiecezjalnego w Łodzi".

214 Według https://pl.wikipedia.org/wiki/Muzeum_Uniwersytetu_Medycznego_w_\%C5\%8 lodzi w Muzeum znajdują się ,cenne starodruki i dokumenty, w tym dzieło Paracelsusa, Zielnik Szymona Syreńskiego (Syreniusza) wydrukowany w języku polskim w 1612 roku, podręczniki chirurgii polowej Ludwika Perzyny". Zob. też http://muzeauczelniane.pl/muzeum-uniwersytetu-medycznego-w-lodzi/.

215 http://cymeliapbwlodz.blogspot.com/2014/11/lkjljjh.html; por. J. Andrzejewski, op. cit., s. 139.

216 J. Andrzejewski, op. cit., s. 139. Biblioteka posiada 1129 starych druków zdigitalizowanych po konserwacji - zob. http://mak.wimbp.lodz.pl/index.php/bazy-katalogowe/stare-druki. html. Zob. też I. Książek, Fragment księgozbioru Konstancji Małachowskiej-Biernackiej w zbiorze starych druków WiMBP w Łodzi, ,Rocznik Książnicy Miejskiej w Łodzi” 1998, s. 22-32.

217 Zob. http://www.malbork.ap.gov.pl/p,104,ksiegozbior. 


\begin{tabular}{|c|c|c|c|}
\hline 189 & Malbork & $\begin{array}{l}\text { Muzeum Zamkowe } \\
\text { (Biblioteka - Zbiory specjalne) } \\
\text { ul. Starościńska 1, 82-200 Malbork }\end{array}$ & $\begin{array}{l}\text { brak szczegółowych } \\
\text { danych }{ }^{218}\end{array}$ \\
\hline 190 & Miechów & $\begin{array}{l}\text { Parafia Grobu Bożego (Biblioteka) } \\
\text { ul. Warszawska 1A, 32-200 Miechów }\end{array}$ & $\begin{array}{l}\text { brak szczegółowych } \\
\text { danych }^{219}\end{array}$ \\
\hline 191 & Międzyrzecz & $\begin{array}{l}\text { Muzeum Ziemi Międzyrzeckiej } \\
\text { im. Alfa Kowalskiego (Dział historii) } \\
\text { ul. Podzamcze 2, 66-300 Międzyrzecz }\end{array}$ & $\begin{array}{l}\text { brak szczegółowych } \\
\text { danych } 220\end{array}$ \\
\hline 192 & Mikołajki & $\begin{array}{l}\text { Muzeum Reformacji Polskiej } \\
\text { pl. Kościelny, 11-730 Mikołajki }\end{array}$ & $\begin{array}{l}\text { brak szczegółowych } \\
\text { danych }\end{array}$ \\
\hline 193 & Mława & $\begin{array}{l}\text { Miejska Biblioteka Publiczna } \\
\text { im. Bolesława Prusa } \\
\text { ul. } 3 \text { maja 5, 06-500 Mława }\end{array}$ & 3 woluminy ${ }^{222}$ \\
\hline 194 & Muszyna & $\begin{array}{l}\text { Parafia św. Józefa } \\
\text { ul. Kościelna 62, 33-370 Muszyna }\end{array}$ & 41 druków 223 \\
\hline 195 & Nieborów & $\begin{array}{l}\text { Pałac (Muzeum Narodowe w Warszawie, } \\
\text { oddział Muzeum w Nieborowie i Arkadii) } \\
\text { al. Lipowa 35, 99-416 Nieborów }\end{array}$ & $\begin{array}{l}\text { około } 12 \text { tysięcy } \\
\text { druków } 224\end{array}$ \\
\hline 196 & $\begin{array}{l}\text { Niepokala- } \\
\text { nów }\end{array}$ & $\begin{array}{l}\text { Biblioteka Klasztorna Ojców Franciszkanów } \\
\text { Konwentualnych } \\
\text { Niepokalanów, 96-515 Teresin }\end{array}$ & kilka woluminów 225 \\
\hline
\end{tabular}

218 Zob. http://www.zamek.malbork.pl/biblioteka/zbiory-specjalne-12. Wiadomo, że w zbiorze znajduje się 14 woluminów druków z XVI wieku — zob. http://www.zamek.malbork.pl/wydarzenia/dotacja-na-konserwacje-starodrukow-568.

219 Zob. M. Kowalski, Sprawozdanie z ogólnopolskiej konferencji: „Bożogrobcy w służbie Sanktuarium Świętego Grobu Jerozolimskiego Naszego Pana Jezusa Chrystusa w Miechowie" Miechów 27-28 maja 2015, „Kieleckie Studia Teologiczne” 15, 2016, s. 384, http://wsd.kielce.pl/ wp-content/uploads/2016/12/KST_15_2016/KST_15_2016_23.pdf; M. Podyma, Druki polskie od XVI do XIX wieku w zbiorach Biblioteki Bożogrobców w Miechowie (praca magisterska), Uniwersytet Pedagogiczny im. Komisji Edukacji Narodowej, Kraków 2008; http://bozogrobcy.miechow. info/.

${ }^{220}$ M. Sołtysiak, K. Wierzbicka, op. cit., s. 133; J. Patorska, Muzeum w Międzyrzeczu, „Rocznik Lubuski” 31, 2005, nr 1, s. 107, http://www.roczniklubuski.uz.zgora.pl/wydania/tom_31/ RL_T31_1_Patorska.pdf; zob. też http://www.muzeum-miedzyrzecz.pl/muzeum/zbiory.html.

${ }^{221}$ Kolekcja obejmuje druki ewangelickie od XVI do XX wieku - zob. M. Sołtysiak, K. Wierzbicka, op. cit., s. 134; https://meteor-turystyka.pl/miejsce/muzeum-reformacji-polskiej-w-mikolajkach; https://polska-org.pl/7665221,Mikolajki,Muzeum_Reformacji_Polskiej.html.

222 Dane na podstawie kwerendy M. Kycler.

223 W. Kmietowicz, Krótka historia biblioteki parafialnej w Muszynie, „Almanach Muszyny" 2004, s. 24-27, http://www.almanachmuszyny.pl/spisy/2004/KROTKA\%20HISTORIA.pdf.

$224 \mathrm{http}: / /$ anhotravel.pl/?product=na-salonach-u-radziwilow-i-chaty-malowane-czyli-nieborow-i-lowicz. Według https://www.powiat.lowicz.pl/474,zabytki-w-powiecie liczba starych druków wynosi ponad 10 tysięcy woluminów. Zob. też M. Sołtysiak, K. Wierzbicka, op. cit., s. 140.

225 Biblioteki Kościoła Katolickiego..., s. 190. 


\begin{tabular}{|c|c|c|c|}
\hline 197 & $\begin{array}{l}\text { Nowe Miasto } \\
\text { nad Pilicą }\end{array}$ & $\begin{array}{l}\text { Muzeum Regionalne } \\
\text { pl. bł. o. H. Koźmińskiego } 1 / 2 \text {, } \\
\text { 26-420 Nowe Miasto nad Pilicą }\end{array}$ & $\begin{array}{l}\text { brak szczegółowych } \\
\text { danych }^{226}\end{array}$ \\
\hline 198 & Nowe Opole & $\begin{array}{l}\text { Biblioteka Wyższego Seminarium Duchownego } \\
\text { Diecezji Siedleckiej } \\
\text { (Dział Zbiorów Specjalnych) } \\
\text { ul. Seminaryjna 26, 08-103 Nowe Opole }\end{array}$ & 44 woluminy 227 \\
\hline 199 & Nowy Sącz & $\begin{array}{l}\text { Muzeum Okręgowe } \\
\text { ul. Jagiellońska 56, 33-300 Nowy Sącz }\end{array}$ & $\begin{array}{l}\text { brak szczegółowych } \\
\text { danych } 228\end{array}$ \\
\hline 200 & Nowy Sącz & $\begin{array}{l}\text { Sądecka Biblioteka Publiczna } \\
\text { im. Józefa Szujskiego } \\
\text { ul. Franciszkańska 11, 33-300 Nowy Sącz }\end{array}$ & 136 woluminów 229 \\
\hline 201 & Nysa & $\begin{array}{l}\text { Muzeum Powiatowe } \\
\text { (Dział Sztuki i Rzemiosła Artystycznego) } \\
\text { ul. Biskupa Jarosława 11, 48-300 Nysa }\end{array}$ & $\begin{array}{l}90 \text { woluminów, } \\
\text { w tym } 7 \text { inkunabu- } \\
\text { łów (w } 4 \text { wolumi- } \\
\text { nach), } 20 \text { wolumi- } \\
\text { nów z XVI wieku, } \\
29 \text { woluminów } \\
\text { z XVII wieku oraz } \\
37 \text { woluminów } \\
\text { z XVIII wieku }\end{array}$ \\
\hline 202 & Oblęgorek & $\begin{array}{l}\text { Pałacyk Henryka Sienkiewicza } \\
\text { (oddział Muzeum Narodowego w Kielcach) } \\
\text { al. Lipowa 24, 26-067 Strawczyn }\end{array}$ & ponad 50 druków ${ }^{231}$ \\
\hline
\end{tabular}

${ }^{226}$ M. Sołtysiak, K. Wierzbicka, op. cit., s. 142; http://muzeum.nowemiasto.pl/2-2/; https:// www.grojec24.net/news-wielkie-muzeum-w-malym-miescie,1806.html.

227 Biblioteki Kościoła Katolickiego..., s. 121; zob. https://wsd.siedlce.pl/biblioteka/dzialy/ zbiory-specjalne/. https://wsd.siedlce.pl/biblioteka/histroiab/: „Pod koniec 1966 r. ponad 120 starodruków ze zbiorów biblioteki seminaryjnej za zgodą ówczesnego biskupa siedleckiego Ignacego Świrskiego zostało przekazanych do Biblioteki Uniwersyteckiej KUL".

228 Według M. Sołtysiak i K. Wierzbickiej (op. cit., s. 142) są to „starodruki cerkiewne”. Zob. też http://karnet.krakow.pl/152-krakow-muzeum-okregowe-w-nowym-saczu; Pietas et litterae. Wplyw kolegium pijarów w Podolińcu na rozwój dawnego szkolnictwa. Katalog wystawy, listopad 2004-marzec 2005 = Vplyv kolégia piaristov v Podolínci na rozvoj školstva v minulosti. Katalóg výstavy, november 2004-marec 2005, red. M. Marcinowska, Nowy Sącz 2004.

229 Dane na podstawie kwerendy M. Kycler. Według W. Wcześnego (Katalog starych druków Sąeckiej Biblioteki Publicznej w Nowym Sączu. Polonica XVI-XVIII w., Nowy Sącz 2001, zwł. s. 6, http://www.sbc.nowysacz.pl/dlibra/docmetadata?id=2210\&from=publication) biblioteka posiada 147 dzieł, w tym polonika — 72 dzieła (4 z XVI wieku, 13 z XVII wieku oraz 55 z XVIII wieku).

230 Informacje na podstawie rozmowy telefonicznej z pracownikiem muzeum panią Pauliną Murzyniak (Dział Sztuki i Rzemiosła Artystycznego) z 8 października 2019 roku. Zob. też M. Sołtysiak, K. Wierzbicka, op. cit., s. 145; http://www.muzeum.nysa.pl/web.n4?go=35; https:// ilovenysa.pl/kultura/obiekt-miesiaca-mapa-slaska-z-xvii-wieku/.

231 Ł. Wojtczak, Starodruki w bibliotece Pałacyku Henryka Sienkiewicza w Oblęgorku, ,Rocznik Muzeum Narodowego w Kielcach" 28, 2013, s. 59; https://mnki.pl/sienkiewicz/pl/dla_zwiedzajacych/wystawy_czasowe/zakonczone/2014/22,skarby_biblioteki_sienkiewiczowskiej. 


\begin{tabular}{|c|l|l|l|}
\hline 203 & Obra & $\begin{array}{l}\text { Biblioteka Wyższego Seminarium Duchownego } \\
\text { Misjonarzy Oblatów Maryi Niepokalanej } \\
\text { ul. Szkolna 12, 64-211 Obra }\end{array}$ & $\begin{array}{l}\text { 179 druków } \\
\text { (w 249 wolu- } \\
\text { minach), w tym } \\
\text { 13 druków z XVI } \\
\text { wieku, 41 druków } \\
\text { z XVII wieku } \\
\text { i 97 druków } \\
\text { z XVIII wieku } \\
\text { (stan na 2016 rok) }\end{array}$ \\
\hline 204 & Olsztyn & $\begin{array}{l}\text { Archiwum Państwowe (Biblioteka) } \\
\text { ul. Partyzantów 18, 10-521 Olsztyn }\end{array}$ & $\begin{array}{l}\text { brak szczegółowych } \\
\text { danych233 }\end{array}$ \\
\hline 205 & Olsztyn & $\begin{array}{l}\text { Biblioteka Muzeum Warmii i Mazur } \\
\text { ul. Zamkowa 2, 10-074 Olsztyn }\end{array}$ & $\begin{array}{l}\text { 2066 druków, } \\
\text { w tym co najmniej } \\
\text { 2 inkunabuły } \\
\text { (w 1 woluminie) }\end{array}$ \\
\hline 206 & Olsztyn & $\begin{array}{l}\text { Biblioteka Wyższego Seminarium Duchownego } \\
\text { Metropolii Warmińskiej „Hosianum” } \\
\text { ul. Stanisława kard. Hozjusza 15, } \\
\text { 11-041 Olsztyn }\end{array}$ & $\begin{array}{l}\text { woluminy, } \\
\text { wing } 324 \text { wolu- } \\
\text { miny inkunabułów } \\
\text { oraz 1559 druków } \\
\text { z XVI wieku235 }\end{array}$ \\
\hline
\end{tabular}

${ }^{232}$ Druki z XVI-XVIII wieku w zbiorze Biblioteki Wyższego Seminarium Duchownego Misjonarzy Oblatów Maryi Niepokalanej w Obrze. Katalog, oprac. H. Mieczkowska, Poznań 2016, s. 11.

233 Zob. Archiwum Państwowe w Olsztynie. Sprawozdanie z działalności w 2015 roku, Olsztyn 2016, s. 13, http://bip.ap.gov.pl/plik.php?id=7052; Archiwum Państwowe w Olsztynie. Sprawozdanie z działalności w 2016 roku, Olsztyn 2017, s. 11, http://bip.ap.gov.pl/plik.php?id=7041.

$234 \mathrm{http} / / /$ muzeum.olsztyn.pl/2149,Biblioteka-Muzeum-Warmii-i-Mazur-w-Olsztynie.html. Nieco inne dane (2063 druki) podaje http://leksykonkultury.ceik.eu/index.php/Biblioteka_Muzeum_Warmii_i_Mazur_w_Olsztynie. W 1984 roku było ich 2007 — zob. E. Guska, Muzeum Warmii i Mazur w Olsztynie w latach 1945-1985, „Komunikaty Mazursko-Warmińskie” 1985, nr 1-2, s. 205. Zob. też M. Sołtysiak, K. Wierzbicka, op. cit., s. 149; D. Konieczna, Biblioteka Muzeum Warmii i Mazur, [w:] Olsztyn 1945-2005: kultura i nauka, red. S. Achremczyk, W. Ogrodziński, Olsztyn 2006, s. 250-254.

$235 \mathrm{http} / / / \mathrm{www} \cdot h o s i a n u m . e d u . p l / i n d e x . p h p ? o p t i o n=c o m \_$content\&view=category\&layout=b $\log \& \mathrm{id}=105 \& I t e m i d=544 ;$ J. Wojtkowski, Katalog druków XVI wieku Biblioteki Wyższego Seminarium Duchownego Metropolii Warmińskiej ,Hosianum” w Olsztynie, Lublin 2012, s. 17; Biblioteki Kościoła Katolickiego..., s. 66. Według J. Witczaka (op. cit.) w bibliotece znajduje się 7616 starych druków, w tym 324 inkunabuły. Zob. też R. Romanowski, Inkunabuty z oficyn niemieckich w Bibliotece Wyższego Seminarium Duchownego w Olsztynie w świetle Centralnego Katalogu Inkunabułów (praca licencjacka), Uniwersytet Mikołaja Kopernika, Toruń 2003; idem, Inkunabuły w Bibliotece Wyższego Seminarium Duchownego w Olsztynie w świetle Centralnego Katalogu Inkunabułów (praca magisterska), Uniwersytet Mikołaja Kopernika, Toruń 2005; J. Obłąk, Z. Jaroszewicz-Pieresławcew, J. Wojtkowski, Katalog inkunabułów Biblioteki Wyższego Seminarium Duchownego Metropolii Warmińskiej „Hosianum” w Olsztynie, Olsztyn 2007; Z. Jaroszewicz-Pieresławcew, Cyrylometodejskie dziedzictwo piśmiennicze na Warmii i Mazurach, „Acta Polono-Ruthenica" 20, 2015, s. 33-42.

\section{ROCZNIKI BIBLIOTECZNE}

ROK LXIII, 2019

(C) for this edition by CNS 


\begin{tabular}{|l|l|l|l|}
\hline 207 & Olsztyn & $\begin{array}{l}\text { Wojewódzka Biblioteka Publiczna } \\
\text { im. Emilii Sukertowej-Biedrawiny } \\
\text { ul. 1 maja 5, 10-117 Olsztyn }\end{array}$ & $\begin{array}{l}\text { 136 druków } \\
\text { (w 63 woluminach), } \\
\text { w tym 13 dru- } \\
\text { ków z XVI wie- } \\
\text { ku, 40 druków } \\
\text { z XVII wieku, } \\
83 \text { druki } \\
\text { z XVIII wieku }\end{array}$ \\
\hline 208 & Ołtarzew & $\begin{array}{l}\text { Biblioteka Wyższego Seminarium } \\
\text { Księży Pallotynów } \\
\text { Ołtarzew, ul. Jana Kilińskiego 20, } \\
\text { 05-850 Ożarów Mazowiecki }\end{array}$ & $\begin{array}{l}1289 \text { woluminów, } \\
\text { w tym 7 woluminów } \\
\text { inkunabułów }\end{array}$ \\
\hline 209 & Opatów & $\begin{array}{l}\text { Kolegiata św. Marcina w Opatowie (Bibliote- } \\
\text { ka)/Archiwum kapituły i parafii Opatów } \\
\text { ul. „Grota” Roweckiego 8, 27-500 Opatów }\end{array}$ & $\begin{array}{l}\text { brak szczegółowych } \\
\text { danych238 }\end{array}$ \\
\hline 210 & Opole & $\begin{array}{l}\text { Archiwum Państwowe (Biblioteka) } \\
\text { ul. Zamkowa 2, 45-016 Opole }\end{array}$ & 172 woluminy $^{239}$ \\
\hline
\end{tabular}

${ }^{236}$ Dane na podstawie kwerendy M. Kycler. Zob. też K. Kresymon, Konserwacja i restauracja starodruku „Constitutiones Synodales Dioecesis Varmiensis” Apud Georgium Schönfels, Brunsbergae 1612. Zbiory Wojewódzkiej Biblioteki Publicznej w Olsztynie, „Bibliotekarz Warmińsko-Mazurski” 3-4, 2013, s. 37-39; A. Romulewicz, Duńczyk na Warmii, „Bibliotekarz Warmińsko-Mazurski" 3-4, 2013, s. 34-36; idem, Stare druki niemieckie w zbiorach Wojewódzkiej Biblioteki Publicznej w Olsztynie, „Bibliotekarz Warmińsko-Mazurski” 3-4, 2014, s. 18-23; K. Kresymon, Stan zachowania starych druków Wojewódzkiej Biblioteki Publicznej w Olsztynie, [w:] Zabytkowe zbiory biblioteczne w województwie warmińsko-mazurskim. Stan zachowania, red. Z. Jaroszewicz-Pieresławcew, D. Konieczna, A. Romulewicz, Olsztyn 2015, s. 162-168; A. Romulewicz, Martin Luthers Psalmen und Biblia Germanica. Alte deutsche Drucke in den Sammlungen der Wowoidenschaftsbibliothek in Allenstein, „Masurische Storchenpost” 2, 2015, s. 3-11, 43; idem, Stare druki w zasobach Wojewódzkiej Biblioteki Publicznej w Olsztynie, [w:] Zabytkowe zbiory biblioteczne w województwie warmińsko-mazurskim..., s. 79-94; idem, Różnorodność językowa zabytkowych zbiorów Wojewódzkiej Biblioteki Publicznej im. Emilii Sukertowej-Biedrawiny w Olsztynie, „Prace Językoznawcze” 4, 2016, s. 192-196.

237 Biblioteki Kościoła Katolickiego..., s. 164; https://pl.wikipedia.org/wiki/Biblioteka Wy\%C5\%BCszego_Seminarium_Duchownego_w_O\%C5\%82tarzewie. Zob. też Idźcie na caty świat... 75 lat Pallotyńskiego Wyższego Seminarium Duchownego, red. J. Nowak, Ołtarzew 1993.

238 M. Rzepecka (Archiwum kapituły i parafii Opatów, „Archiwa, Biblioteki i Muzea Kościelne" 93, 2010, s. 262) podaje, iż w bibliotece zgromadzono 800-900 egzemplarzy starych druków i nowszych książek. W samym zaś archiwum mieszczą się Katalog Biblioteki Kapituty Opatowskiej sporządzony przez ks. Leona Figarskiego. Według https://pl.wikipedia.org/wiki/ Kolegiata_\%C5\%9Bw._Marcina_w_Opatowie w bibliotece znajdują się ,inkunabuły oraz starodruki”, a także „księgozbiór dzieł teologicznych i filozoficznych w liczbie około 500 woluminów”.

$239 \mathrm{http} / / /$ opole.ap.gov.pl/zasob/biblioteka-podreczna.html. 


\begin{tabular}{|c|l|l|l|}
\hline 211 & Opole & $\begin{array}{l}\text { Biblioteka Główna Uniwersytetu Opolskiego } \\
\text { (Oddział Gromadzenia i Opracowania } \\
\text { Wydawnictw Ciągłych i Zbiorów Specjalnych) } \\
\text { Strzelców Bytomskich 2, 45-084 Opole }\end{array}$ & $\begin{array}{l}\text { 650 woluminów } \\
\text { (stan na 2013 rok) })^{240}\end{array}$ \\
\hline 212 & Opole & $\begin{array}{l}\text { Biblioteka Wydziału Teologicznego } \\
\text { Uniwersytetu Opolskiego } \\
\text { ul. Wojciecha Drzymały 1A, 45-342 Opole }\end{array}$ & $\begin{array}{l}\text { 7704 druki, w tym } \\
136 \text { inkunabułów } 241\end{array}$ \\
\hline 213 & Opole & $\begin{array}{l}\text { Muzeum Śląska Opolskiego } \\
\text { (Dział historii) } \\
\text { ul. św. Wojciecha 13, 45-023 Opole }\end{array}$ & $\begin{array}{l}\text { brak szczegółowych } \\
\text { danych }{ }^{242}\end{array}$ \\
\hline 214 & Opole & $\begin{array}{l}\text { Pedagogiczna Biblioteka Wojewódzka } \\
\text { ul. Kościuszki 14, 45-062 Opole }\end{array}$ & $\begin{array}{l}100 \text { druków w } 106 \\
\text { woluminach, } \\
\text { w tym 7 dru- } \\
\text { ków z XVI wie- } \\
\text { ku, 10 druków } \\
\text { z XVII wieku, } \\
83 \text { druki z XVIII } \\
\text { wieku } 243\end{array}$ \\
\hline
\end{tabular}

240 B. Orłowska, B. Smentek, D. Wierzbicka-Próchniak, Udział Biblioteki Głównej Uniwersytetu Opolskiego w tworzeniu zasobów [prezentacja w ramach VII Zebrania Uczestników Śląskiej Biblioteki Cyfrowej, 28.11.2013 roku], slajd 3, https://sbc.org.pl/Content/81786/Udzia\%C5\%82\%20 Biblioteki\%20G\%C5\%82\%C3\%B3wnej\%20Uniwersytetu\%20Opolskiego\%20w\%20tworzeniu\%20zasob\%C3\%B3w\%20\%C5\%9Al\%C4\%85skiej\%20Biblioteki\%20Cyfrowej.pdf. W 2001 roku zbiór liczył 578 starodruków — zob. W. Matwiejczuk, Biblioteka Gtówna Uniwersytetu Opolskiego 2001-2011. Daty i fakty, Opole 2011, s. 16, https://sbc.org.pl/Content/164070/tmpf264.pdf.

241 J. Witczak, op. cit. Według T. Grabuńczyka (Pochodzenie i historia starych druków przechowywanych w Bibliotece Wydziału Teologicznego Uniwersytetu Opolskiego, „Pomagamy Sobie w Pracy" 2004, nr 3, s. 16, http://www.bibliotekarzopolski.pl/arch/043.pdf) w 2004 roku w bibliotece znajdowało się około 6 tysięcy woluminów starych druków, w tym 122 inkunabuły. Do zbiorów tych należy również kolekcja z Biblioteki Seminarium Duchownego w Nysie, w ramach której w XIX wieku przechowywano 10 tysięcy starych druków (dzieł), stanowiących około 8 tysięcy woluminów, w tym prawie 170 inkunabułów — zob. ibidem, s. 14.

${ }^{242}$ M. Sołtysiak, K. Wierzbicka, op. cit., s. 152; http://muzeum.opole.pl/kolekcje/historia/; U. Zajączkowska, Starodruki i druki śląskie w zbiorach Muzeum Śląska Opolskiego w Opolu, „Opolski Rocznik Muzealny” 9, 1989, s. 35-68; zob. też https://pl.wikipedia.org/wiki/ Muzeum_\%C5\%9Al\%C4\%85ska_Opolskiego_w_Opolu.

${ }^{243}$ Katalog starodruki w zbiorach Pedagogicznej Biblioteki Wojewódzkiej w Opolu, oprac. A. Paszkowska, Opole 2009, s. 5. Według https://pedagogiczna.pl/2017/10/30/zbiory-pedagogicznej-biblioteki-wojewodzkiej-opolu/ zbór liczy 111 druków. 


\begin{tabular}{|c|c|c|c|}
\hline 215 & Opole & $\begin{array}{l}\text { Wojewódzka Biblioteka Publiczna } \\
\text { im. Emanuela Smołki } \\
\text { ul. Piastowska 18-19-20, 45-081 Opole } \\
\text { Zbiory przechowywane w Zamku/Zespole } \\
\text { pałacowo-parkowym w Rogowie Opolskim } \\
\text { (Oddział Zbiorów Specjalnych i Zabytkowych) } \\
\text { ul. Parkowa 38, 47-300 Rogów Opolski }\end{array}$ & $\begin{array}{l}2868 \text { woluminów, } \\
\text { w tym } 4 \text { inkunabuły } \\
\text { (stan na } 2004 \text { rok) }^{244}\end{array}$ \\
\hline 216 & Oświęcim & $\begin{array}{l}\text { Muzeum Zamek } \\
\text { ul. Zamkowa 1, Oświęcim 32-600 }\end{array}$ & $\begin{array}{l}\text { brak szczegółowych } \\
\text { danych }\end{array}$ \\
\hline 217 & Pelplin & $\begin{array}{l}\text { Biblioteka Diecezjalna } \\
\text { im. Biskupa Jana Bernarda Szlagi } \\
\text { ul. Biskupa Dominika 7, 83-130 Pelplin }\end{array}$ & $\begin{array}{l}\text { około } 13 \text { tysięcy } \\
\text { druków, w tym } \\
543 \text { inkunabuły }{ }^{246}\end{array}$ \\
\hline 218 & Pelplin & $\begin{array}{l}\text { Muzeum Diecezjalne } \\
\text { ul. Biskupa Dominika 11, 83-130 Pelplin }\end{array}$ & $\begin{array}{l}\text { brak szczegółowych } \\
\text { danych }{ }^{247}\end{array}$ \\
\hline 219 & $\begin{array}{l}\text { Piotrków } \\
\text { Trybunalski }\end{array}$ & $\begin{array}{l}\text { Miejska Biblioteka Publiczna } \\
\text { im. Adama Próchnika } \\
\text { ul. Jerozolimska 29, } \\
\text { 97-300 Piotrków Trybunalski }\end{array}$ & $\begin{array}{l}41 \text { druków w } 45 \\
\text { woluminach) }^{248}\end{array}$ \\
\hline
\end{tabular}

244 M. Koćwin, Przegląd zbiorów zabytkowych Wojewódzkiej Biblioteki Publicznej w Opolu, „Pomagamy Sobie w Pracy” 2004, nr 3, s. 38, http://www.bibliotekarzopolski.pl/arch/043.pdf; zob. też M. Wójcik, Proweniencje starych druków Wojewódzkiej Biblioteki Publicznej w Opolu, „Acta Universitatis Wratislaviensis. Bibliotekoznawstwo" 21, 1998, s. 79-93; M. Kalczyńska, Starodruki Śląskie w zbiorach Wojewódzkiej Biblioteki Publicznej im. E. Smołki w Opolu, „Bibliotekarz” 4-5, 1989, s. 17-22; https://wbp.opole.pl/zbiory; https://wbp.opole.pl/wsrod-starodrukow.

245 Zob. https://dzieje.pl/aktualnosci/unikatowy-zielnik-syreniusza-trafil-do-zbiorow-muzeum-w-oswiecimiu; https://oswiecim.pl/iii-jarmark-kasztelanski-z-krolowa-bona/1490/.

246 http://biblioteka.diecezja-pelplin.pl/historia-1. Według Bibliotek Kościoła Katolickiego... (s. 106) zbiory te w 2005 roku liczyły 12543 woluminy starych druków, w tym 543 woluminy inkunabułów. Zob. też B. Derkowska-Kostkowska, S. Warmijak, Gotycka rzeźba pomorska i starodruki z XV wieku ze zbiorów Muzeum Diecezjalnego i Biblioteki Diecezjalnej w Pelplinie, Bydgoszcz 1992; K. Nierzwicki, Pozostałości biblioteki biskupa Stanisława Wojciecha Okoniewskiego w zbiorach Książnicy WSD w Pelplinie, „Studia Pelplińskie” 26, 1997, s. 79-103; M. Urbaniak, Inkunabuty Opactwa Cysterskiego w Bibliotece Wyższego Seminarium Duchownego w Pelplinie (praca licencjacka), Uniwersytet Mikołaja Kopernika, Torun 2003; B. Beszczyńska, Inkunabuty Biblioteki Wyższego Seminarium Duchownego w Pelplinie zarejestrowane w Gesamthkatalog der Wiegiendrucke (praca licencjacka), Uniwersytet Mikołaja Kopernika, Toruń 2004; A. Kruszyńska, Straty wojenne w polskich zbiorach inkunabulów. Biblioteka Wyższego Seminarium Duchownego w Pelplinie (praca licencjacka), Uniwersytet Mikołaja Kopernika, Torun 2003; K. Nowak, Straty wojenne w latach 1939-1945 w Bibliotece Seminaryjnej w Pelplinie w kolekcji inkunabułów (praca magisterska), Uniwersytet Mikołaja Kopernika, Toruń 2014.

247 M. Sołtysiak, K. Wierzbicka, op. cit., s. 158; http://www.muzeum.diecezja.org/muzeum/ nasze-zbiory/; http://www.muzeum.diecezja.org/muzeum/nasze-zbiory/biblia-gutenberga/.

248 Dane na podstawie kwerendy M. Kycler. 


\begin{tabular}{|c|c|c|c|}
\hline 220 & $\begin{array}{l}\text { Piotrków } \\
\text { Trybunalski }\end{array}$ & $\begin{array}{l}\text { Muzeum (Dział historii) } \\
\text { pl. Zamkowy 4, 97-300 Piotrków Trybunalski }\end{array}$ & $\begin{array}{l}\text { brak szczegółowych } \\
\text { danych }\end{array}$ \\
\hline 221 & Pisz & $\begin{array}{l}\text { Muzeum Ziemi Piskiej } \\
\text { pl. Daszyńskiego 7, 12-200 Pisz }\end{array}$ & $\begin{array}{l}\text { brak szczegółowych } \\
\text { danych }\end{array}$ \\
\hline 222 & Płock & $\begin{array}{l}\text { Biblioteka im. Zielińskich Towarzystwa } \\
\text { Naukowego Płockiego } \\
\text { pl. Narutowicza 2, 09-402 Płock }\end{array}$ & $\begin{array}{l}13366 \text { woluminów, } \\
\text { w tym } 93 \text { woluminy } \\
\text { inkunabułów }{ }^{251}\end{array}$ \\
\hline 223 & Płock & $\begin{array}{l}\text { Biblioteka Wyższego Seminarium Duchownego } \\
\text { ul. abp. A. Nowowiejskiego 2, 09-400 Płock }\end{array}$ & $\begin{array}{l}1676 \text { druków } \\
\text { (w } 1653 \text { wolu- } \\
\text { minach) [1968 } \\
\text { z defektami], w tym } \\
11 \text { inkunabułów } \\
\text { (w } 10 \text { woluminach), } \\
220 \text { druków (209 } \\
\text { woluminów) z XVI } \\
\text { wieku [+ } 10 \text { defek- } \\
\text { tów], } 405 \text { druków } \\
\text { (393 woluminy) } \\
\text { z XVII wieku } \\
\text { [+ } 161 \text { defektów] } \\
\text { oraz } 1051 \text { druków } \\
\text { (1051 woluminów) } \\
\text { z XVIII wieku } \\
\text { [+ } 121 \text { defektów] } 252\end{array}$ \\
\hline
\end{tabular}

249 M. Sołtysiak, K. Wierzbicka, op. cit., s. 161; http://muzeumpiotrkow.pl/aktualnosci/ wystawa-starodruki-i-ksiazki-pomoca-naukowa/; http://www.piotrkow.pl/pl/kultura-i-edukacja-t72/aktualnosci-a108/starodruki-w-muzeum-r12161; https:/www.epiotrkow.pl/news/O-dziejach-i-zagladzie-gminy-zydowskiej-w-Piotrkowie.-Zobacz-wyjatkowa-wystawe-w-naszym-muzeum, 37130 .

${ }^{250}$ M. Sołtysiak, K. Wierzbicka, op. cit., s. 161; https://pl.wikipedia.org/wiki/Muzeum_Ziemi_Piskiej_w_Piszu.

251 http://www.tnp.org.pl/oferta.html; zob. też W. Kaczanowska, Najstarsze drukowane Biblie w zbiorach Biblioteki im. Zielińskich TNP (XV-XVIII w.), „Notatki Płockie” 3, 1992, s. 8-14; eadem, Kolekcja starych Biblii (XV-XVIII w.) w zbiorach Biblioteki im. Zielińskich Towarzystwa Naukowego Płockiego, „Notatki Płockie” 3, 1994, s. 17-20.

252 W. Graczyk, J.M. Marszalska, Księgi rękopiśmienne i stare druki w zbiorach Biblioteki Wyższego Seminarium Duchownego w Płocku. Z dziejów kultury polskich bibliotek kościelnych w dawnych wiekach, Kraków 2010, s. 37. Według Bibliotek Kościoła Katolickiego... (s. 110) w 2005 roku w zbiorach tych miało znajdować się około 4 tysięcy starych druków. Zob. też http://www.wsdplock.pl/o-nas/biblioteka; B. Trojanowska, Stare druki z biblioteki miejskiej dawnego Królewca w Bibliotece Seminarium Duchownego w Płocku (praca magisterska), Uniwersytet Mikołaja Kopernika, Toruń 1995; M. Sitek, Straty wojenne w polskich zbiorach inkunabułów. Biblioteka Seminarium Duchownego w Płocku. Druki niemieckie (praca licencjacka), Uniwersytet Mikołaja Kopernika, Toruń 2003; eadem, Straty wojenne w polskich zbiorach inkunabułów. Biblioteka Seminarium Duchownego w Płocku (praca magisterska), Uniwersytet Mikołaja Kopernika, Toruń 2005.

\section{ROCZNIKI BIBLIOTECZNE}

ROK LXIII, 2019

(C) for this edition by CNS 


\begin{tabular}{|c|c|c|c|}
\hline 224 & Płock & $\begin{array}{l}\text { Muzeum Diecezjalne } \\
\text { ul. Tumska 3A, 09-402 Płock }\end{array}$ & $\begin{array}{l}\text { brak szczegółowych } \\
\text { danych }{ }^{253}\end{array}$ \\
\hline 225 & Poznań & $\begin{array}{l}\text { Archiwum Państwowe } \\
\text { ul. por. Janiny Lewandowskiej 41/43, } \\
\text { 60-967 Poznań }\end{array}$ & $\begin{array}{l}1525 \text { druków, w tym } \\
1 \text { inkunabut, } 38 \text { dru- } \\
\text { ków z XVI wieku, } \\
531 \text { druków z XVII } \\
\text { wieku, } 939 \text { druków } \\
\text { z XVIII wieku, } \\
6 \text { druków z prze- } \\
\text { łomu XVIII/XIX } \\
\text { wieku (zdefekto- } \\
\text { wane) (stan na } 2016 \\
\text { rok) }\end{array}$ \\
\hline 226 & Poznań & $\begin{array}{l}\text { Biblioteka Główna i Centrum Informacji } \\
\text { Naukowej Uniwersytetu Przyrodniczego } \\
\text { ul. Witosa 45, 61-693 Poznań }\end{array}$ & $\begin{array}{l}\text { brak szczegółowych } \\
\text { danych }^{255}\end{array}$ \\
\hline 227 & Poznań & $\begin{array}{l}\text { Biblioteka Główna Uniwersytetu Medycznego } \\
\text { im. Karola Marcinkowskiego } \\
\text { ul. Przybyszewskiego 37A, 60-356 Poznań }\end{array}$ & 491 druków 256 \\
\hline 228 & Poznań & $\begin{array}{l}\text { Biblioteka Poznańskiego Towarzystwa Przyja- } \\
\text { ciół Nauk } \\
\text { ul. Mielżyńskiego 27/29, 61-725 Poznań }\end{array}$ & $\begin{array}{l}\text { ponad } 15 \text { tysięcy } \\
\text { druków, w tym } 1408 \\
\text { z XVI wieku }\end{array}$ \\
\hline 229 & Poznań & $\begin{array}{l}\text { Biblioteka Raczyńskich } \\
\text { al. Marcinkowskiego 23, 61-745 Poznań }\end{array}$ & $\begin{array}{l}17986 \text { wolumi- } \\
\text { nów }\end{array}$ \\
\hline
\end{tabular}

${ }^{253}$ Zob. https://ekai.pl/jedno-z-najcenniejszych-i-najstarszych-muzeum-diecezjalne-w-plocku/.

${ }^{254}$ M. Janeczek, Katalog starych druków Archiwum Państwowego w Poznaniu, Poznań 2016, s. 21, 23.

255 Wiadomo, że biblioteka ta posiada kilkaset starych druków, które zostały podtopione w 2015 roku — zob. https://www.wprost.pl/zycie/513955/zalana-biblioteka-uniwersytecka-w-poznaniu-tysiace-ksiazek-do-wyrzucenia.html.

256 http://www.bg.ump.edu.pl/info/charakt.php; https://gazetawroclawska.pl/uniwersytet-medyczny-ma-nowoczesna-biblioteke-stara-bierze-kosciol/ar/8968574.

257 Spośród wymienionych druków z XVI wieku 562 to polonika — zob. http://biblioteka. ptpn.poznan.pl/o-bibliotece/zbiory/. Zob. też Katalog starych druków Biblioteki Poznańskiego Towarzystwa Przyjaciót Nauk. Polonica XVI wieku, oprac. E. Stelmaszczyk, Poznań 1991.

258 Dane na podstawie kwerendy M. Kycler. Według http://www.bracz.edu.pl/index. php?option=com_content\&task=view\&id $=44 \&$ Itemid $=45 \#$ starydruk $\mathrm{w}$ bibliotece znajduje się prawie 18 tysięcy starych druków, w tym 253 inkunabuły. Zob. też Katalog der Raczyńskischen Bibliothek in Posen, T. 1. Biographie des Grafen Eduard Raczyński, Geschichte der Bibliothek, Manuscripte, Urkunden, Inkunabeln, Theologie, Rechtswissenschaft, Philosophie, Paedagogik, Mathematik, Naturwissenschaften, Landwirthschaft, Gewerbe, Handel, Kunst, Kriegswissenschaft, Medicin, oprac. M.E. Sosnowski, L. Kurtzmann, Posen 1885; Katalog der Raczyńskischen Bibliothek in Posen, T. 2. Literatur u. Geschichte, oprac. M.E. Sosnowski, L. Kurtzmann, Posen 1885; Katalog der Raczyńskischen Bibliothek in Posen, T. 3. Polnische Geschichte u. Literatur, oprac. M.E. Sosnowski, L. Kurtzmann, Posen 1885; Katalog der Raczyńskischen Bibliothek in Po- 


\begin{tabular}{|c|c|c|c|}
\hline 230 & Poznań & $\begin{array}{l}\text { Biblioteka Uniwersytetu Adama Mickiewicza } \\
\text { (Oddział Zbiorów Specjalnych — Pracownia } \\
\text { Starych Druków) } \\
\text { ul. Ratajczaka 38/40, 61-816 Poznań }\end{array}$ & $\begin{array}{l}\text { około } 75 \text { tysięcy wo- } \\
\text { luminów, w tym } 377 \\
\text { inkunabułów (w } 322 \\
\text { woluminach) }^{259}\end{array}$ \\
\hline 231 & Poznań & $\begin{array}{l}\text { Biblioteka Wydziału Teologicznego } \\
\text { Uniwersytetu Adama Mickiewicza } \\
\text { Oddział Rękopisów i Starodruków } \\
\text { (Archiwum Archidiecezjalne) } \\
\text { ul. ks. Ignacego Posadzego 2, 61-108 Poznań }\end{array}$ & $\begin{array}{l}3508 \text { druków, w tym } \\
799 \text { inkunabułów } 260\end{array}$ \\
\hline 232 & Poznań & $\begin{array}{l}\text { Centralna Biblioteka Starodruków i Rękopisów } \\
\text { (Klasztor Franciszkanów) } \\
\text { ul. Garbary 22, 61-867 Poznań }\end{array}$ & $\begin{array}{l}\text { szacunkowo około } \\
9550 \text { druków, w tym } \\
172 \text { inkunabuły }\end{array}$ \\
\hline 233 & Poznań & $\begin{array}{l}\text { Muzeum Historii Miasta Poznania } \\
\text { (oddział Muzeum Narodowego) } \\
\text { Stary Rynek 1, 61-768 Poznań }\end{array}$ & $\begin{array}{l}\text { brak szczegółowych } \\
\text { danych }^{262}\end{array}$ \\
\hline 234 & Przemyśl & $\begin{array}{l}\text { Archiwum Archidiecezjalne } \\
\text { pl. Katedralny 4A, 37-700 Przemyśl }\end{array}$ & $\begin{array}{l}\text { brak szczegółowych } \\
\text { danych }{ }^{263}\end{array}$ \\
\hline
\end{tabular}

sen, T. 4. Indices, oprac. M.E. Sosnowski, L. Kurtzmann, Posen 1885. A. Bederski, Druki poznańskie wieku XVI-XVIII znajdujace się w Bibljotece Raczyńskich, Poznań 1929; Katalog Bibljoteki Raczyńskich w Poznaniu: 1885-1931, T. 1. Dokumenty nr 231-237, rękopisy nr 360-499 i druki A do K, oprac. A. Wojtkowski, Poznań 1932; D. Gołębiewska, Stare druki w Bibliotece Raczyńskich w Poznaniu. Informator, Poznań 1998.

259 Dane na podstawie informacji udzielonej przez jednego z recenzentów niniejszego opracowania. Według informacji zamieszczonej na stronie internetowej biblioteki (http://lib.amu.edu. $\mathrm{pl} /$ pracownia-starych-drukow/) księgozbiór ten zawiera około 80 tysięcy woluminów druków. Zob. W. Wydra, Katalog inkunabułów Biblioteki Uniwersyteckiej w Poznaniu, Poznań 2002, s. 5; zob. też Z. Kawecka, Materiaty do Katalogu inkunabutów Biblioteki Głównej Uniwersytetu im. A. Mickiewicza, Poznań 1960; J. Cybertowicz, H. Kowalewicz, Katalog druków polskich XVI wieku Biblioteki Głównej Uniwersytetu im. Adama Mickiewicza w Poznaniu, Poznań 1963.

260 http://aap.poznan.pl/zasob/biblioteka-wt-uam-oddzial-rekopisow-i-starodrukow/; zob. też J. Nowacki, Dzieje Archidiecezji Poznańskiej, T. 2. Archidiecezja Poznańska w granicach historycznych i jej ustrój, Poznań 1964, s. 233-235.

261 Stan zbiorów starodrucznych ustalony na podstawie http://www.franciszkanie.poznan. $\mathrm{pl} /$ ?p=main\&what=16 oraz Rękopisy $w$ zbiorach kościelnych..., s. 294. Zob. też Muzea Kościoła katolickiego..., s. 100; S.B. Tomczak, Biblioteka Główna Prowincji Św. Franciszka z Asyżu Zakonu Braci Mniejszych w Poznaniu, „Forum Bibliotek Medycznych” 10, 2017, nr 1, s. 282-340, http:// digital.fides.org.pl/Content/1766/Tomczak_2017.pdf; M. Prusaczyk, Inkunabuty biblioteki Bernardynów w Poznaniu w świetle Centralnego Katalogu Inkunabutów (praca licencjacka), Uniwersytet Mikołaja Kopernika, Toruń 2003.

262 W zbiorze tym znajdują się również inkunabuły — zob. https://www.mnp.art.pl/oddzialy/ muzeum-historii-miasta-poznania/zbiory/.

263 Według Archiwów Kościoła Katolickiego... (s. 88) w archiwum znajdują się austriackie druki rządowe z końca XVIII wieku. 


\begin{tabular}{|c|l|l|l|}
\hline 235 & Przemyśl & $\begin{array}{l}\text { Archiwum Państwowe (Biblioteka) } \\
\text { ul. Lelewela 4, 37-700 Przemyśl }\end{array}$ & $\begin{array}{l}113 \text { druków, } \\
\text { w 70 woluminów } \\
\text { (stan na 1993 rok) }\end{array}$ \\
\hline 236 & Przemyśl & $\begin{array}{l}\text { Biblioteka Kapituły Metropolitalnej } \\
\text { (Archidiecezja Przemyska) } \\
\text { ul. Kapitulna 2, 37-700 Przemyśl }\end{array}$ & 7017 woluminów ${ }^{265}$ \\
\hline 237 & Przemyśl & $\begin{array}{l}\text { Archidiecezja Przemysko-Warszawska } \\
\text { Kościoła Greckokatolickiego [wcześniej: } \\
\text { Biblioteka Archidiecezjalna im. Biskupa } \\
\text { Konstantego Czechowicza (przy ul. Basztowej 13)] } \\
\text { ul. bp. Jozafata Kocyłowskiego 4, } \\
\text { 37-700 Przemyśl }\end{array}$ & $\begin{array}{l}\text { 180 woluminów } \\
\text { (stan na 2005 rok) }\end{array}$ \\
\hline 238 & Przemyśl & $\begin{array}{l}\text { Biblioteka Muzeum Narodowego } \\
\text { Ziemi Przemyskiej } \\
\text { pl. Berka Joselewicza 1, 37-700 Przemyśl }\end{array}$ & $\begin{array}{l}\text { ków (w tym } \\
\text { inkunabuły) }\end{array}$ \\
\hline 239 & Przemyśl & $\begin{array}{l}\text { Biblioteka Towarzystwa Przyjaciół Nauk } \\
\text { im. Kazimierza Marii Osińskiego } \\
\text { ul. Kościuszki 7, 37-700 Przemyśl }\end{array}$ & $\begin{array}{l}\text { 261 druków (w 432 } \\
\text { woluminach) } \\
\text { głównie z XVIII } \\
\text { wieku) }\end{array}$ \\
\hline 2408 & Przemyśl & $\begin{array}{l}\text { Biblioteka Wyższego Seminarium Duchownego } \\
\text { ul. Zamkowa 5, 37-700 Przemyśl }\end{array}$ & $\begin{array}{l}\text { 6500 druków, w tym } \\
\text { 22 inkunabuły }{ }^{269}\end{array}$ \\
\hline$\{240\}$ & $\{$ Przemyśl $\}$ & $\begin{array}{l}\text { Klasztor Karmelitanek Bosych } \\
\text { ul. Tatarska 7, 37-700 Przemyśl }\}\end{array}$ & $\begin{array}{l}\text { \{brak szczegóło- } \\
\text { wych danych }\}\end{array}$ \\
\hline
\end{tabular}

264 E. Długosz, Starodruki w Archiwum Państwowym w Przemyślu, Przemyśl 1993, s. 6. Większą część zbioru (80 pozycji inwentarzowych) tworzą konstytucje i ustawy sejmowe oraz materiały do historii ustroju i państwa polskiego.

265 Biblioteki Kościoła Katolickiego..., s. 263; zob. też http://przemyska.pl/ks-dominik-bialic/.

266 Biblioteki Kościoła Katolickiego..., s. 261. Zob. też E. Zawałeń, Prezentacja zbiorów cerkiewnych Greckokatolickiej Archidiecezji Przemysko-Warszawskiej, [w:] Muzea kościelne wobec nowych wyzwań, red. N.W. Błażejczyk, P. Majewski, Warszawa 2019, s. 303, https://www.nimoz. pl/files/publications/61/Muzea\%20ko\%C5\%9Bcielne\%20internet.pdf; http://cerkiew.org/historia/.

267 http://mnzp.pl/pl/biblioteka. Według E. Długosz (op. cit., s. 8) w 1993 roku zbiór liczył około 1 tysiąca druków, w tym 1 inkunabuł.

268 E. Długosz, Stare druki w zbiorach Towarzystwa Przyjaciót Nauk w Przemyślu. Katalog, Przemyśl 1999, s. 8.

269 Roczne sprawozdanie z działalności Biblioteki Seminarium Duchownego w Przemyślu, „Fides: Biuletyn Bibliotek Kościelnych” 1-2, 2005, s. 109, http://digital.fides.org.pl/Content/1209/07-Slemp.pdf; J. Witczak, op. cit. Według E. Ślemp (Biblioteka Wyższego Seminarium Duchownego w Przemyślu, „Fides: Biuletyn Bibliotek Kościelnych” 1-2, 2005, s. 103) w 2005 roku w bibliotece było około 5 tysięcy dzieł starych druków. Podobne dane znajdziemy również w: Biblioteki Kościoła Katolickiego..., s. 112, gdzie podano, że w zbiorach jest 5027 woluminów starych druków, w tym 27 woluminów inkunabułów.

\section{ROCZNIKI BIBLIOTECZNE}

ROK LXIII, 2019

(C) for this edition by CNS 


\begin{tabular}{|c|c|c|c|}
\hline 241 & Przemyśl & $\begin{array}{l}\text { Opactwo Benedyktynek } \\
\text { pl. Konstytucji } 3 \text { maja 8, 37-700 Przemyśl }\end{array}$ & $\begin{array}{l}\text { brak szczegółowych } \\
\text { danych }\end{array}$ \\
\hline 242 & Przemyśl & $\begin{array}{l}\text { Parafia Ojców Franciszkanów } \\
\text { pw. św. Antoniego z Padwy } \\
\text { ul. Jagiellońska 2, 37-700 Przemyśl }\end{array}$ & $\begin{array}{l}\text { brak szczegółowych } \\
\text { danych }\end{array}$ \\
\hline 243 & Pszczyna & $\begin{array}{l}\text { Muzeum Zamkowe } \\
\text { ul. Brama Wybrańców 1, 43-200 Pszczyna }\end{array}$ & $\begin{array}{l}230 \text { druków (XVI- } \\
\text { początek XIX } \\
\text { wieku) (stan na } \\
2009 / 2010 \text { rok) } \\
\text { iek2 }\end{array}$ \\
\hline 244 & Racibórz & $\begin{array}{l}\text { Miejska i Powiatowa Biblioteka Publiczna } \\
\text { im. Ryszarda Kincla } \\
\text { ul. Jana Kasprowicza 12, 47-400 Racibórz }\end{array}$ & 2 woluminy 273 \\
\hline 245 & Racibórz & $\begin{array}{l}\text { Muzeum (Dział historii) } \\
\text { ul. Rzeźnicza 15, 47-400 Racibórz }\end{array}$ & $\begin{array}{l}\text { około } 50 \text { druków, } \\
\text { w tym } 1 \text { inkuna- } \\
\text { buł }^{274}\end{array}$ \\
\hline 246 & Radom & $\begin{array}{l}\text { Miejska Biblioteka Publiczna im. Józefa } \\
\text { Andrzeja i Andrzeja Stanisława Załuskich } \\
\text { ul. J. Piłsudskiego 12, 26-600 Radom }\end{array}$ & 240 woluminów 275 \\
\hline 247 & Radom & $\begin{array}{l}\text { Muzeum im. Jacka Malczewskiego } \\
\text { Rynek 11, 26-600 Radom }\end{array}$ & około 100 druków 276 \\
\hline 248 & Radom & $\begin{array}{l}\text { Wyższe Seminarium Duchowne } \\
\text { ul. Młyńska 23/25, 26-616 Radom }\end{array}$ & około 150 druków 277 \\
\hline 249 & Rybnik & $\begin{array}{l}\text { Muzeum (Dział historii i kultury regionu) } \\
\text { Rynek 18, 44-200 Rybnik }\end{array}$ & $\begin{array}{l}\text { brak szczegółowych } \\
\text { danych }\end{array}$ \\
\hline
\end{tabular}

${ }^{270}$ Zob. http://archiwalne.radio.rzeszow.pl/informacje/42519/siostry-benedyktynki-udostepnia-stare-druki; http://rzeszow.wyborcza.pl/rzeszow/1,34962,3535117.html.

271 Zob. http://www2.kki.pl/pioinf/przemysl/zabytki/koscioly/refor/refor.html.

272 „Wieści Sudeckiego UTW”, nr 14, II semestr 2009/2010, s. 29, http://www.sudecki-utw. walbrzych.pl/wiesci14.pdf; w liczbie tej także druki z początku XIX wieku.

273 Dane na podstawie kwerendy M. Kycler.

274 http://muzeum.raciborz.pl/dzialy-izb/dzial-historia/. W 2002 roku w Muzeum i Bibliotece Miejskiej miało być razem ponad 200 starych druków — zob. https://www.nowiny.pl/egazeta/ nowiny-raciborskie/2002-02-20/17156-dziela-starych-oficyn.html.

275 Dane na podstawie kwerendy M. Kycler. Zob. też http://www.mbpradom.pl/index.php/ obibliotece/his1: „Miejska Biblioteka Publiczna przejęła wówczas [po II wojnie światowej — K.S.] zbiory wszystkich przedwojennych bibliotek radomskich w liczbie 39000 woluminów. Wśród nich był cenny, bo zawierający także s t a r o d r u k i, liczący 9000 tomów, zbiór z Biblioteki Sejmikowej im. Stefana Hempla. Część z nich została potem zwrócona prawowitym właścicielom. Tak stało się z księgozbiorem biblioteki żydowskiej, który przekazano Gminie Żydowskiej w Lublinie".

$276 \mathrm{http} / / / \mathrm{www} . \mathrm{muzeum}$. edu.pl/pl/radom/biblioteka,34.htm; por. https://pl.wikipedia.org/ wiki/Muzeum_im._Jacka_Malczewskiego_w_Radomiu.

277 Informacje na podstawie http://seminarium.radom.pl/?page_id=533. Zob. też M. Mizerska, Starodruki Biblioteki Wyższego Seminarium Duchownego w Rádomiu (praca magisterska), Uniwersytet Marii Curie-Skłodowskiej, Lublin 2007.

${ }^{278}$ Zob. http://www.muzeum.rybnik.pl/pl/29,dzial-historii-i-kultury-regionu.html. 


\begin{tabular}{|c|c|c|c|}
\hline 250 & $\begin{array}{l}\text { Rzepiennik } \\
\text { Strzyżewski }\end{array}$ & $\begin{array}{l}\text { Muzeum przy parafii Miłosierdzia Bożego } \\
\text { (filia Muzeum Diecezjalnego w Tarnowie) } \\
\text { 33-163 Rzepiennik Strzyżewski } 67\end{array}$ & $\begin{array}{l}\text { brak szczegółowych } \\
\text { danych }\end{array}$ \\
\hline 251 & Rzeszów & $\begin{array}{l}\text { Biblioteka Instytutu Teologiczno-Pastoralnego } \\
\text { i Wyższego Seminarium Duchownego } \\
\text { ul. Witolda 11A, 35-302 Rzeszów }\end{array}$ & 78 druków 280 \\
\hline 252 & Rzeszów & $\begin{array}{l}\text { Biblioteka Sióstr Karmelitanek Bosych } \\
\text { ul. Morgowa 98, 35-301 Rzeszów }\end{array}$ & 1 wolumin $^{281}$ \\
\hline 253 & Rzeszów & $\begin{array}{l}\text { Muzeum Okręgowe (Biblioteka) } \\
\text { ul. } 3 \text { maja 19, 35-030 Rzeszów }\end{array}$ & $\begin{array}{l}\text { brak szczegółowych } \\
\text { danych } 282\end{array}$ \\
\hline 254 & Rzeszów & $\begin{array}{l}\text { Wojewódzka i Miejska Biblioteka Publiczna } \\
\text { ul. Sokoła 13, 35-010 Rzeszów }\end{array}$ & 434 woluminy $^{283}$ \\
\hline 255 & Sandomierz & $\begin{array}{l}\text { Biblioteka Diecezjalna } \\
\text { ul. Żeromskiego 6, 27-600 Sandomierz }\end{array}$ & 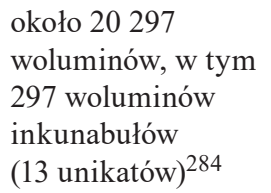 \\
\hline
\end{tabular}

${ }^{279}$ Muzea Kościoła katolickiego..., s. 118.

280 http://www.biblioteka.wsd.rzeszow.pl/index.php/o-nas. Z kolei B. Dec (Biblioteka Instytutu Teologiczno-Pastoralnego i Wyższego Seminarium Duchownego w Rzeszowie, „Fides: Biuletyn Bibliotek Kościelnych" 2, 2015, s. 56, http://digital.fides.org.pl/dlibra/docmetadata?from=rss\&id=174) podaje, że „w kolekcji starodruków znajduje się dziewięćdziesiąt sześć pozycji”. Same zaś zbiory starych druków w Bibliotece Wyższego Seminarium Duchownego w 2013 roku wynosiły 37 tytułów w 28 woluminach objętych katalogiem oraz 41 woluminach nieopracowanych - zob. A. Przywara, Biblioteka Wyższego Seminarium Duchownego w Rzeszowie: dwadzieścia lat istnienia, „,Resovia Sacra. Studia Teologiczno-Filozoficzne Diecezji Rzeszowskiej" 18-20, 2011-2013, s. 415, http://bazhum. muzhp.pl/media//files/Resovia_Sacra_Studia_Teologiczno_Filozoficzne_Diecezji_Rzeszowskiej/ Resovia_Sacra_Studia_Teologiczno_Filozoficzne_Diecezji_Rzeszowskiej-r2011_2013-t18_20/ Resovia_Sacra_Studia_Teologiczno_Filozoficzne_Diecezji_Rzeszowskiej-r2011_2013-t18_20-s409-420/Resovia_Sacra_Studia_Teologiczno_Filozoficzne_Diecezji_Rzeszowskiej-r2011_2013-t18_20-s409-420.pdf. Wēłług Bib̆liotek Kościoła Katolickiego... (s. 116) w 2005 roku w samej Bibliotece WSD Diecezji Rzeszowskiej miało znajdować się 25 woluminów starych druków. Zob. też A. Przywara, Starodruki w zbiorach Biblioteki Wyższego Seminarium Duchownego w Rzeszowie. Zarys problematyki, Rzeszów 2012, s. 7, 27; zob. też eadem, Starodruki w bibliotece Wyższego Seminarium Duchownego w Rzeszowie (praca magisterska), Uniwersytet Warszawski, Warszawa 2008.

281 Biblioteki Kościoła Katolickiego..., s. 241.

282 Na stronie internetowej prezentowane są 4 druki, w tym 1 inkunabuł — zob. http://www. muzeum.rzeszow.pl/pl/biblioteka-zbiory/. Zob. też S. Darłakowa, Starodruki polskie XVI-XVIII w. w zbiorach Biblioteki Muzeum w Rzeszowie. Katalog, Rzeszów 1965; R. Płonka, Polskie druki i polonica do roku 1820 w zbiorach Biblioteki Muzeum Okręgowego w Rzeszowie, Rzeszów 2000.

283 Dane na podstawie kwerendy M. Kycler. Zob. też http://www.wimbp.rzeszow.pl/biblioteka/zbiory/.

284 Biblioteki Kościoła Katolickiego..., s. 119; http://www.bdsandomierz.pl/historia.html. Około 2 tysiące druków pochodzą ze zbiorów Kapituły Kolegiackiej i Katedralnej w Sandomierzu. Według J. Witczaka (op. cit.) w zbiorach tych znajduje się 17 tysięcy starych druków, w tym 300 inkunabułów. Zob. też J. Rokoszny, Stare druki przechowywane w bibliotece seminaryjnej w Sando- 


\begin{tabular}{|c|l|l|l|}
\hline 256 & Sandomierz & $\begin{array}{l}\text { Miejska Biblioteka Publiczna } \\
\text { im. Jana Długosza } \\
\text { ul. Parkowa 1, 27-600 Sandomierz }\end{array}$ & $\begin{array}{l}\text { około 35 druków } \\
\text { (stan na 2017 rok) }\end{array}$ \\
\hline 257 & Sanok & $\begin{array}{l}\text { Muzeum Historyczne } \\
\text { ul. Zamkowa 2, 38-500 Sanok }\end{array}$ & $\begin{array}{l}\text { około 300 druków } \\
\text { cyrylickich z XVI- } \\
\text { XX wieku }\end{array}$ \\
\hline 258 & $\begin{array}{l}\text { Sędziszów } \\
\text { Małopolski }\end{array}$ & $\begin{array}{l}\text { Klasztor Zakonu Braci Mniejszych Kapucynów } \\
\text { ul. Jana Pawła II 42, } \\
\text { 39-120 Sędziszów Małopolski }\end{array}$ & 2900 druków ${ }^{287}$ \\
\hline 259 & Siedlce & $\begin{array}{l}\text { Muzeum Diecezjalne (Biblioteka starodruków } \\
\text { i innych ksiąg zabytkowych) } \\
\text { ul. bp. I. Świrskiego 56, 08-110 Siedlce }\end{array}$ & $\begin{array}{l}\text { brak szczegółowych } \\
\text { danych } 288\end{array}$ \\
\hline
\end{tabular}

mierzu, „Kwartalnik Teologiczny” 1902, nr 3-4, s. 1-6; J. Mazur-Pietrzyk, Druki sandomierskie przechowywane w Bibliotece Seminarium Duchownego w Sandomierzu (praca magisterska), Uniwersytet Jana Kochanowskiego, Kielce 1984; D. Rejman, Promocja realizacji projektu „,Konserwacja, digitalizacja i udostępnianie kolekcji starych druków opatrzonych superekslibrisami ze zbiorów Biblioteki Diecezjalnej w Sandomierzu”, „Fides: Biuletyn Bibliotek Kościelnych” 2, 2014, s. 43-50; I. Bąkowska, Druki jezuickie i pojezuickie w zbiorach Biblioteki Wyższego Seminarium Duchownego w Sandomierzu (praca magisterska), Wyższa Szkoła Pedagogiczna im. Jana Kochanowskiego, Kielce 1998; B. Ciastek, Inkunabuly w zbiorach Biblioteki Seminarium Duchownego w Sandomierzu (praca magisterska), Wyższa Szkoła Pedagogiczna im. Jana Kochanowskiego, Kielce 1999; A. Leśniak-Błasiak, Motywy biblijne na ilustracjach drzeworytowych inkunabułów Biblioteki Wyższego Seminarium Duchownego w Sandomierzu (praca magisterska), Akademia Świętokrzyska im. Jana Kochanowskiego, Kielce 2004; K. Małkowska, Inkunabuly w zbiorach Biblioteki Wyższego Seminarium Duchownego w Sandomierzu (praca magisterska), Uniwersytet Mikołaja Kopernika, Toruń 2008; https://pl.wikipedia.org/wiki/Biblioteka_Diecezjalna_w_Sandomierzu.

285 http://www.sandomierz.naszabiblioteka.com/o-nas/historia; http://www.mbpsand.internetdsl.pl/historia.htm. Zob. też Wykaz zbiorów dotyczących Sandomierza znajdujących się w Miejskiej Bibliotece Publicznej w Sandomierzu, s. 1, http://www.sandomierz.naszabiblioteka.com/pliki/plik/drukisandomierskie20wrzesnia2017-1505905744.pdf.

286 http://www.podkarpacie24.pl/aktualnosci/9/1776; http://www.muzeum.sanok.pl/pl/zbiory/biblioteka.

$287 \mathrm{http} / / /$ www.sedziszow.kapucyni.pl/klasztor/poznaj-klasztor. Według https://sedziszowmlp.pl/o-miescie/zabytki oraz https://pl.wikipedia.org/wiki/S\%C4\%99dzisz $\%$ C3\%B3w_Ma\%C5 \%82opolski zbiór liczy 4 tysiące druków. Zob. też A. Ziętek, Starodruki polskojęzyczne w klasztorze oo. Kapucynów w Sędziszowie Małopolskim (praca magisterska), Wyższa Szkoła Pedagogiczna, Kraków 1994.

288 Muzea Kościoła katolickiego..., s. 125-126. W muzeum znajduje się „,iekawy zbiór starodruków, mszałów, modlitewników i dokumentów pochodzących z kancelarii watykańskich i królewskich, pisanych ręcznie na pergaminie (XVI-XX wiek)" — zob. http://muzeum.siedlce. pl/zbiory/starodruki/; http://cojestgrane24.wyborcza.pl/cjg24/Siedlce/1,43,423607,Starodruki-i-dokumenty-na-pergaminie.html.

\section{ROCZNIKI BIBLIOTECZNE}

ROK LXIII, 2019

(C) for this edition by CNS 


\begin{tabular}{|c|c|c|c|}
\hline 260 & Sieradz & $\begin{array}{l}\text { Muzeum Okręgowe (Dział Starodruków) } \\
\text { ul. Dominikańska 2, 98-200 Sieradz }\end{array}$ & $\begin{array}{l}1500 \text { druków (w tym } \\
\text { inkunabuły) (stan } \\
\text { na lata 50. XX } \\
\text { wieku) } \\
289\end{array}$ \\
\hline 261 & Skoczów & $\begin{array}{l}\text { Muzeum parafialne im. św. Jana Sarkandra } \\
\text { Rynek 2, 43-430 Skoczów }\end{array}$ & $\begin{array}{l}\text { brak szczegółowych } \\
\text { danych }\end{array}$ \\
\hline 262 & Słupsk & $\begin{array}{l}\text { Akademia Pomorska (Biblioteka) } \\
\text { ul. Arciszewskiego 22C, 76-200 Słupsk }\end{array}$ & $\begin{array}{l}\text { brak szczegółowych } \\
\text { danych }\end{array}$ \\
\hline 263 & Słupsk & $\begin{array}{l}\text { Muzeum Pomorza Środkowego } \\
\text { ul. Dominikańska 5-9, 76-200 Słupsk }\end{array}$ & 315 druków 292 \\
\hline 264 & Sobótka & $\begin{array}{l}\text { Muzeum Ślężańskie } \\
\text { im. Stanisława Dunajewskiego } \\
\text { ul. św. Jakuba 18, 55-050 Sobótka }\end{array}$ & $\begin{array}{l}\text { brak szczegółowych } \\
\text { danych }\end{array}$ \\
\hline 265 & Sosnowiec & $\begin{array}{l}\text { Miejska Biblioteka Publiczna im. Gustawa } \\
\text { Daniłowskiego } \\
\text { ul. Kościelna 11, 41-200 Sosnowiec }\end{array}$ & 7 woluminów 294 \\
\hline 266 & Stadniki & $\begin{array}{l}\text { Wyższe Seminarium Misyjne Księży Sercanów } \\
\text { Stadniki 81, 32-422 Stadniki }\end{array}$ & $\begin{array}{l}234 \text { woluminy, } \\
\text { w tym } 1 \text { inkuna- } \\
\text { but }^{295}\end{array}$ \\
\hline
\end{tabular}

289 http://muzeum-sieradz.com.pl/biblioteka-2/. W zbiorze tym znajdują się również druki z klasztoru dominikanów — zob. https://muzeum-sieradz.com.pl/stare-druki-z-sieradzkiego-klasztoru-dominikanskiego-w-muzeum-okregowym-w-sieradzu-2/; https://www.powiat-sieradz. pl/index.php/historia-i-kultura/2583-spuscizna-po-dominikanach-w-zbiorach-muzeum. Zob. też M. Sołtysiak, K. Wierzbicka, op. cit., s. 196.

290 Muzea Kościoła katolickiego..., s. 127; https://dziedzictwo.ekai.pl/@@skoczow_muzeum_parafialne_sw_jana_sarkandra_.

291 https://biblioteka.apsl.edu.pl/zasoby.php; zob. też M. Babicz, Zbiór rękopisów i starych druków Biblioteki Głównej Wyższej Szkoły Pedagogicznej w Stupsku. Katalog (praca magisterska), Uniwersytet Gdański, Gdańsk 1985; https://www.kurtiak-ley.pl/starodruki-konserwacja/.

292 A. Konias, Przegląd planów miasta Stupska od XVIII do XX wieku ze zbiorów Biblioteki Muzeum Pomorza Środkowego, „Słupskie Prace Geograficzne” 6, 2009, s. 146, https://spg.apsl. edu.pl/baza/wydawn/spg06/konias_strzelecki.pdf; zob. też http://www.muzeum.slupsk.pl/index. php/16-o-muzeum/struktura-mps; http://www.muzeum.slupsk.pl/index.php/oferta/biblioteka/ konserwacja-starodrukow.

293 M. Sołtysiak, K. Wierzbicka, op. cit., s. 200; zob. też https://muzeum.sobotka.pl/?page_ $\mathrm{id}=14$.

294 Dane na podstawie kwerendy M. Kycler.

295 Biblioteki Kościoła Katolickiego..., s. 178. 44 z tych druków zostało skatalogowanych komputerowo; w bibliotece pozostaje nadal około 3 tysięcy woluminów nieskatalogowanych podręczników oraz dubletów — zob. L. Poleszak, Wyższe Seminarium Misyjne Księży Sercanów w Stadnikach - historia i teraźniejszość, ,Sympozjum” 1, 2004, nr 12, s. 254-255, http://cejsh.icm. edu.pl/cejsh/element/bwmetal.element.desklight-ca13f373-0712-497c-8172-f9adcf47b078/c/15_ Poleszak_L_-_Wyzsze_Seminarium_MIsyjne_Ksiezy_Sercanow_w_Stadnikach.pdf; http://www. seminarium.scj.pl/strony/nasza-historia. Zob. też K. Ruman, Starodruki Biblioteki Wyższego Se- 


\begin{tabular}{|c|c|c|c|}
\hline 267 & Staniątki & $\begin{array}{l}\text { Opactwo św. Wojciecha Mniszek Benedyktynek } \\
\text { Staniątki 299, 32-005 Niepołomice }\end{array}$ & $\begin{array}{l}2327 \text { druków oraz } \\
2 \text { woluminy inkuna- } \\
\text { bułów }^{296}\end{array}$ \\
\hline 268 & Stara Wieś & $\begin{array}{l}\text { Zgromadzenie Sióstr Służebniczek Najświęt- } \\
\text { szej Maryi Panny Niepokalanie Poczętej } \\
\text { (Biblioteka) } \\
\text { Stara Wieś 460, 36-200 Brzozów }\end{array}$ & kilkaset druków 297 \\
\hline 269 & Stargard & $\begin{array}{l}\text { Biblioteka Muzeum Archeologiczno-Historycz- } \\
\text { nego } \\
\text { Rynek Staromiejski 2-4, 73-110 Stargard }\end{array}$ & $\begin{array}{l}107 \text { druków, w tym } \\
3 \text { z XVI wieku, } \\
43 \text { druki z XVII } \\
\text { wieku, } 67 \text { z XVIII } \\
\text { wieku (stan na } 2012 \\
\text { rok) }\end{array}$ \\
\hline 270 & Stargard & $\begin{array}{l}\text { Książnica Stargardzka } \\
\text { ul. Mieszka I 1, 73-110 Stargard }\end{array}$ & $\begin{array}{l}5 \text { druków, w tym } \\
\text { co najmniej } 4 \text { druki } \\
\text { ulotne z XVII wie- } \\
\mathrm{ku}^{299}\end{array}$ \\
\hline$\{270\}$ & $\{$ Stary Sącz $\}$ & $\begin{array}{l}\text { \{Klasztor Sióstr Klarysek (Biblioteka) } \\
\text { ul. Bandurskiego 6/pl. św. Kingi 1, } \\
\text { 33-340 Stary Sącz\} }\end{array}$ & $\begin{array}{l}\{\text { brak szczegóło- } \\
\left.\text { wych danych }^{300}\right\}\end{array}$ \\
\hline
\end{tabular}

minarium Duchownego w Stadnikach (praca magisterska), Uniwersytet Pedagogiczny im. Komisji Edukacji Narodowej, Kraków 2010.

296 Biblioteki Kościoła Katolickiego..., s. 220; zob. też http://www.benedyktynki.eu/index. php?ram=s\&id=28; https://www.deon.pl/religia/kosciol-i-swiat/z-zycia-kosciola/art,32528, benedyktynki-ze-staniatek-prosza-o-pomoc-pomozmy-uratowac-dziedzictwo-narodowe.html; Z. Klima, Druki XVII-wieczne w języku polskim w ksieggozbiorze klasztoru pp. Benedyktynek w Staniq̨tkach (praca magisterska), Wyższa Szkoła Pedagogiczna im. Komisji Edukacji Narodowej, Kraków 1995.

$297 \mathrm{http} / / /$ www.szkolastarawies.cba.pl/index.php/stara-wie; https://opencaching.pl/viewcache.php?wp=OP8WFN.

298 Według M. Kurzyńskiej (Kolekcje starych druków..., slajd 37-44) w bibliotece funkcjonuje katalog 46 druków (w rękopisie) oraz 2 artykuły na temat tego zbioru; 60\% kolekcji stanowią pomeranika z zakresu historii, teologii, sztuki, medycyny oraz prawa i administracji). Zob. też eadem, Druki pomorskie..., slajd 5-8; M. Sołtysiak, K. Wierzbicka, op. cit., s. 203.

299 A. Puławski, B. Śpiechowicz, Najciekawsze zbiory historyczne Ksiażnicy Stargardzkiej, Stargard 2017; http://stargard.naszemiasto.pl/artykul/ksiaznica-stargardzka-noc-bibliotek-2018-w-naszym-miescie,4673886,artgal,t,id,tm.html. Zob. też https://www.youtube.com/ watch? $\mathrm{v}=3 \mathrm{qC}$ CtByiwJr0.

300 Zob. G. Hudáková, D. Kristeková, M. Styczyński, Stary Sacz i Lewocza. Karpackie miasteczka z klimatem, Kraków 2011, s. 40, http://www.maslev.sk/txt/Zauj\%C3\%ADmavosti/stary_sacz-lewocza_PL\%5B1\%5D.pdf. 


\begin{tabular}{|c|c|c|c|}
\hline 271 & Stary Sącz & $\begin{array}{l}\text { Muzeum Regionalne im. Seweryna Udzieli } \\
\text { oraz Muzeum Księdza Józefa Tischnera, } \\
\text { tak zwany Dom na Dołkach } \\
\text { Rynek 6, 33-340 Stary Sącz }\end{array}$ & $\begin{array}{l}\text { brak szczegółowych } \\
\text { danych }^{301}\end{array}$ \\
\hline 272 & $\begin{array}{l}\text { Sucha } \\
\text { Beskidzka }\end{array}$ & $\begin{array}{l}\text { Muzeum Miejskie } \\
\text { ul. Zamkowa 1, 34-200 Sucha Beskidzka }\end{array}$ & $\begin{array}{l}\text { brak szczegółowych } \\
\text { danych }^{302}\end{array}$ \\
\hline 273 & Suwałki & $\begin{array}{l}\text { Archiwum Państwowe (Biblioteka) } \\
\text { ul. T. Kościuszki 69, 16-400 Suwałki }\end{array}$ & $\begin{array}{l}\text { brak szczegółowych } \\
\text { danych }{ }^{303}\end{array}$ \\
\hline 274 & Szczecin & $\begin{array}{l}\text { Archiwum Archidiecezjalne } \\
\text { ul. Papieża Pawła VI 2, 71-459 Szczecin }\end{array}$ & $\begin{array}{l}\text { zbiory z Biblioteki } \\
\text { Trzebiatowskiej } \\
\text { (od } 2014 \text { roku): } \\
404 \text { druki (w } 98 \text { wo- } \\
\text { luminach), w tym } 44 \\
\text { druki z XVI wieku, } \\
326 \text { druków z XVII } \\
\text { wieku, } 25 \text { druków } \\
\text { z XVIII wieku oraz } \\
9 \text { druków bez roku } \\
\text { wydania } \\
\text { zbiory z Kamie- } \\
\text { nia Pomorskiego } \\
\text { (od } 2004 \text { roku): } \\
506 \text { druków (w } 444 \\
\text { woluminach), w tym } \\
21 \text { inkunabułów, }\end{array}$ \\
\hline
\end{tabular}

301 Według http://www.malopolska24.pl/index.php/2014/04/w-7-dni-dookola-sadecczyzny-stary-sacz/ oraz http://www.wstarymsaczu.pl/atrakcje/zabytki/muzeum-regionalne-im-seweryna-udzieli-dom-na-dolkach/w muzeum znajduje się wiele cennych starych druków. Część z nich ma pochodzić z byłego klasztoru franciszkanów - zob. http://krakow.wyborcza.pl/krakow/1,358 25,7974422,Spacerownik__Stary_Sacz.html.

302 Zob. https://www.muzeum.sucha-beskidzka.pl/zbiory_muzeum.html. W 2018 roku do Suchej Beskidzkiej przeniesiono zbiory starych druków z Muzeum Emila Zegadłowicza w Gorzeniu Górnym — zob. M. Sołtysiak, K. Wierzbicka, op. cit., s. 58-59. Według https://pl.wikipedia. org/wiki/Zamek_w_Suchej_Beskidzkiej w 1932 roku zbiory Muzeum w Suchej Beskidzkiej zawierały między innymi „22 inkunabuły oraz 666 XVI-wiecznych tomów wydanych drukiem”.

303 Zob. http://www.suwalki.ap.gov.pl/p,87,biblioteka-archiwum. 


\begin{tabular}{|c|c|c|c|}
\hline & & & $\begin{array}{l}198 \text { druków (w } 150 \\
\text { woluminach) z XVI } \\
\text { wieku, } 168 \text { druków } \\
\text { (w } 124 \text { woluminach) } \\
\text { oraz } 119 \text { druków } \\
\text { (w } 149 \text { woluminach) } \\
\text { z XVIII wieku } \\
\text { (stan z lat } 80 . \text { XX } \\
\text { wieku) } \\
\text { [oba zbiory pier- } \\
\text { wotnie w Bibliotece } \\
\text { Wydziału Teologicz- } \\
\text { nego Uniwersytetu } \\
\text { Szczecińskiego] } \\
\text { (stan na } 2017 \text { rok) }\end{array}$ \\
\hline 275 & Szczecin & $\begin{array}{l}\text { Archiwum Państwowe (Biblioteka) } \\
\text { ul. św. Wojciecha 13, 70-410 Szczecin }\end{array}$ & $\begin{array}{l}1669 \text { druków, w tym } \\
2 \text { inkunabuły, } \\
131 \text { druków z XVI } \\
\text { wieku, } 310 \text { druków } \\
\text { z XVII wieku, } 726 \\
\text { (szacunkowo) dru- } \\
\text { ków z XVIII wieku } \\
\text { (stan na } 2017 \text { rok) }\end{array}$ \\
\hline
\end{tabular}

${ }^{304}$ Najwyższa zachowana sygnatura z Biblioteki Trzebiatowskiej: 374 - zob. K. Zabuski, Katalog starodruków trzebiatowskich (praca magisterska), http://www.archiwum.szczecin.pl/index.php?art_id=205; http://www.archiwum.szczecin.pl/index.php?art_id=200; http://www.archiwum.szczecin.pl/?id=45; S. Dąbrowski [edyt. Z. Lec], Katalog starych druków dawnej Biblioteki Katedralnej w Kamieniu Pomorskim (Stan z lat 80. XX w.), [w:] Biblioteki i archiwa kościelne na Pomorzu Zachodnim i Ziemi Lubuskiej w latach 1945-2005, red. G. Wejman, Szczecin 2005, s. 56. Zob. też J. Waluś, Od biblioteki seminaryjnej do uniwersyteckiej. Historia Biblioteki Wydziatu Teologicznego Uniwersytetu Szczecińskiego, „Colloquia Theologica Ottoniana” 1, 2017, s. 134-136, http://cejsh.icm.edu.pl/cejsh/element/bwmeta1.element.desklight-c0f41a99-6939-422f-8dda-cd7e596b43c5/c/walus.pdf. Według Bibliotek Kościoła Katolickiego... (s. 123) w 2005 roku w zbiorach tych znajdowało się około 130 woluminów starych druków.

$305 \mathrm{~W}$ ramach tych zbiorów wydzielono również 49 pomeraników z XVI wieku, 156 pomeraników z XVII wieku oraz 500 pomeraników z XVIII wieku — zob. Pomeranica XVI i XVII w. w zbiorach biblioteki Archiwum Państwowego w Szczecinie. Katalog, oprac. J. Kosman, Szczecin 2013; Pomeranica XVIII wieku w zbiorach biblioteki Archiwum Państwowego w Szczecinie. Katalog, oprac. J. Kosman, Szczecin 2016; Stare druki XV-XVII wieku w zbiorach biblioteki Archiwum Państwowego w Szczecinie. Katalog, oprac. J. Kosman, Szczecin 2017, zwł. s. 3, https:// www.szczecin.ap.gov.pl/media/publikacje/2017/Katalog\%20starych\%20druk\%C3\%B3w\%20XV-XVII\%20w.pdf.

\section{ROCZNIKI BIBLIOTECZNE}

ROK LXIII, 2019

(C) for this edition by CNS 


\begin{tabular}{|c|c|c|c|}
\hline 276 & Szczecin & $\begin{array}{l}\text { Biblioteka Główna Pomorskiego Uniwersytetu } \\
\text { Medycznego } \\
\text { al. Powstańców Wielkopolskich 20, } \\
\text { 70-204 Szczecin }\end{array}$ & $\begin{array}{l}53 \text { druki, w tym } 10 \\
\text { druków z XVI wie- } \\
\text { ku, } 8 \text { druków z XVII } \\
\text { wieku, } 35 \text { druków } \\
\text { z XVIII wieku } \\
\text { (stan na } 2013 \text { rok) }^{306}\end{array}$ \\
\hline 277 & Szczecin & $\begin{array}{l}\text { Biblioteka Główna Uniwersytetu Szczecińskiego } \\
\text { (Czytelnia Zbiorów Specjalnych) } \\
\text { ul. Franciszka Tarczyńskiego 1, 70-387 Szczecin }\end{array}$ & 231 druków 307 \\
\hline 278 & Szczecin & $\begin{array}{l}\text { Biblioteka Główna Zachodniopomorskiego } \\
\text { Uniwersytetu Technologicznego } \\
\text { (Zbiory specjalne) } \\
\text { ul. Ku Słońcu 140, 71-073 Szczecin }\end{array}$ & $\begin{array}{l}\text { brak szczegółowych } \\
\text { danych }^{308}\end{array}$ \\
\hline 279 & Szczecin & $\begin{array}{l}\text { Książnica Pomorska im. Stanisława Staszica } \\
\text { (Dział Zbiorów Specjalnych - Pracownia } \\
\text { Starych Druków) [od } 1995 \text { Miejska Biblioteka } \\
\text { Publiczna obsługuje wszystkie filie będące } \\
\text { wcześniej pod opieką Książnicy Pomorskiej] } \\
\text { ul. Podgórna 15/16, 70-205 Szczecin }\end{array}$ & $\begin{array}{l}32514 \text { druków, } \\
\text { w tym } 55 \text { inkunabu- } \\
\text { lów }^{309}\end{array}$ \\
\hline 280 & Szczecin & $\begin{array}{l}\text { Muzeum Historii Szczecina } \\
\text { (oddział Muzeum Narodowego) } \\
\text { ul. Księcia Mściwoja II 8, 70-533 Szczecin }\end{array}$ & $\begin{array}{l}9 \text { druków (1 druk } \\
\text { ulotny, } 8 \text { dzieł } \\
\text { książkowych) (stan } \\
\text { na } 2012 \text { rok) })^{310}\end{array}$ \\
\hline
\end{tabular}

306 Wśród druków z XVIII wieku 3 są w języku polskim — zob. A. Kojder, Starodruki w zbiorach Biblioteki Głównej Pomorskiego Uniwersytetu Medycznego w Szczecinie, „Forum Bibliotek Medycznych" 6, 2013, nr 1 (11), s. 279, http://cybra.lodz.pl/Content/7368/278_FBM_2013_ nrl.pdf.

307 https://bg.szczecin.pl/czytelnie/.

308 https://bg.zut.edu.pl/strona-glowna-bg/o-bibliotece/informacje-o-bibiotece.html.

309 Dane na podstawie kwerendy M. Kycler. Według http://www.ksiaznica.szczecin.pl/www/ stare-druki w Książnicy Pomorskiej znajduje się 30 tysięcy starych druków, w tym 41 woluminów inkunabułów (52 dzieła). Wśród zbioru starych druków można ponadto wyróżnić 2200 woluminów poloników oraz 4 tysiące woluminów pomeraników. Zob. też U. Szajko, Katalog dzieł nautologicznych XV-XVIII w. w zbiorach Wojewódzkiej i Miejskiej Biblioteki Publicznej w Szczecinie, Szczecin 1978; Katalog starych druków Książnicy Szczecińskiej. Pomeranica XVI wieku, oprac. U. Szajko, Szczecin 1988; Katalog starych druków Ksiażnicy Pomorskiej. Pomeranica XVI i XVII wieku, oprac. U. Szajko, Szczecin 2003; A. Michalska, A. Łojko, Katalog inkunabułów Książnicy Pomorskiej w Szczecinie, Szczecin 2016.

310 M. Kurzyńska, Kolekcja starych druków Biblioteki Muzeum Narodowego w Szczecinie, „Cenne, Bezcenne, Utracone” 2012, nr 4 (73), s. 25, https://issuu.com/nimoz/docs/cenne_bezcenne_utracone_4_73/23.

\section{ROCZNIKI BIBLIOTECZNE}

ROK LXIII, 2019

(C) for this edition by CNS 


\begin{tabular}{|c|l|l|l|}
\hline 281 & Szczecin & $\begin{array}{l}\text { Muzeum Narodowe (Biblioteka) } \\
\text { ul. Staromłyńska 27, 70-561 Szczecin }\end{array}$ & $\begin{array}{l}\text { 577 druków w 744 } \\
\text { woluminach, w tym } \\
\text { 29 druków z XVI } \\
\text { wieku, 180 druków } \\
\text { z XVII wieku, 352 } \\
\text { druków z XVIII } \\
\text { wieku (stan na 2012 } \\
\text { rok) }\end{array}$ \\
\hline 282 & Szczecin & $\begin{array}{l}\text { Zamek Książąt Pomorskich } \\
\text { ul. Korsarzy 34, 70-540 Szczecin }\end{array}$ & $\begin{array}{l}\text { brak szczegółowych } \\
\text { danych }\end{array}$ \\
\hline 283 & Szczecinek & $\begin{array}{l}\text { Muzeum Regionalne } \\
\text { ul. Szkolna 1, 78-400 Szczecinek }\end{array}$ & $\begin{array}{l}141 \text { druków, w tym } \\
11 \text { z XVIII wieku } \\
\text { (stan na 2012 rok) }\end{array}$ \\
\hline 284 & Szczyrzyc & $\begin{array}{l}\text { Biblioteka Opactwa Cystersów } \\
\text { 34-623 Szczyrzyc 1 }\end{array}$ & $\begin{array}{l}\text { 77 inkunabułów } \\
\text { w 51 woluminach } \\
\text { (stan na 2002 rok) }\end{array}$ \\
\hline 285 & Świdnica & $\begin{array}{l}\text { Muzeum Dawnego Kupiectwa } \\
\text { Rynek 37, 58-100 Świdnica }\end{array}$ & $\begin{array}{l}\text { brak szczegółowych } \\
\text { danych }\end{array}$ \\
\hline
\end{tabular}

$31140 \%$ tych zbiorów to pomeranika (8 z XVI wieku, 82 z XVII wieku, 148 z XVIII wieku); polonika obejmują 17 tytułów. Kolekcja zawiera dzieła z zakresu historii, teologii, sztuki, medycyny, prawa i administracji, alchemii, architektury i numizmatyki. 14 druków zgromadzono jeszcze przed 1945 rokiem, a 25\% zasobu wymaga obecnie konserwacji — zob. M. Kurzyńska, Kolekcje starych druków..., slajd 37-43; eadem, Druki pomorskie..., slajd 5-8; eadem, Kolekcja starych druków Biblioteki..., s. 23.

312 Zob. http://zamek.szczecin.pl/kalendarz.php?id=6424; https://dzieje.pl/aktualnosci/polskie-rody-magnackie-na-zamku-ksiazat-pomorskich-w-szczecinie.

313 Są to zbiory z zakresu historii i teologii, z czego 140 tytułów to pomeranika, a 1 - polonika. Kolekcja zawiera również 128 mów pogrzebowych z XVI-XVII wieku — zob. M. Kurzyńska, Kolekcje starych druków..., slajd 37-43; eadem, Druki pomorskie..., slajd 5-8.

314 Katalog inkunabułów Biblioteki Opactwa OO. Cystersów w Szczyrzycu, oprac. J.M. Marszalska, Kraków 2002, s. 10. W przedwojennym katalogu inkunabułów G. Kowalski podawał, że bibliotece znajduje się 79 inkunabułów — zob. idem, Katalog inkunabułów biblioteki Opactwa mogilskiego, oraz katalog inkunabułów biblioteki klasztoru Cystersów w Szczyrzycu, Kraków 1915. W bibliotece przechowywane są również druki z XVI-XVIII wieku — zob. http://www.szczyrzyc. cystersi.pl/muzeum.php. Zob. też. J.M. Marszalska, Inwentarze ksiąg biblioteki opactwa cystersów w Szczyrzycu do końca XIX wieku, ,Saeculum Christianum. Pismo Historyczne” 22, 2015, s. 184193, http://cejsh.icm.edu.pl/cejsh/element/bwmeta1.element.desklight-8888e846-a0ae-4d2a-beca-d58fed19072a; eadem, Inkunabuly klasztoru oo. Cystersów w Szczyrzycu. Aktualny stan badań, „Rocznik Sądecki” 30, 2002, s. 139-156; eadem, Inkunabuly w zbiorach Biblioteki Opactwa oo. Cystersów w Szczyrzycu. Zarys problematyki, „Z Badań nad Polskimi Księgozbiorami Historycznymi” 21, 2003, s. 321-342; eadem, Opaci komedataryjni wobec ksiażki. Przyczynek do dziejów Opactwa oo. Cystersów w Szczyrzycu, [w:] Klasztor w Państwie średniowiecznym i nowożytnym, Wrocław-Opole-Warszawa 2005, s. 351-363; eadem, Biblioteka Opactwa Cystersów w Szczyrzycu do końca XIX stulecia. Dziedzictwo wieków, Tarnów 2007.

315 Zob. http://www.mojemiasto.swidnica.pl/?p=1022; http://www.twoje-sudety.pl/index.php ?action=show\&type=news\&id=6724; http://um.swidnica.pl/pages/posts/kosciol-pokoju-na-liscie-unesco-juz-10-lat-185.php.

\section{ROCZNIKI BIBLIOTECZNE}

ROK LXIII, 2019

(C) for this edition by CNS 


\begin{tabular}{|c|c|c|c|}
\hline 286 & Świdnica & $\begin{array}{l}\text { Parafia Ewangelicko-Augsburska } \\
\text { (Kościół Pokoju) } \\
\text { pl. Pokoju 6, 58-00 Świdnica }\end{array}$ & około 37 druków 316 \\
\hline 287 & Święta Anna & $\begin{array}{l}\text { Klasztor w Świętej Annie } \\
\text { (Siostry Dominikanki) } \\
\text { Aleksandrówka 42, 42-248 Przyrów }\end{array}$ & $\begin{array}{l}\text { brak szczegółowych } \\
\text { danych }{ }^{317}\end{array}$ \\
\hline$\{287\}$ & $\begin{array}{l}\text { \{Święta } \\
\text { Katarzyna\} }\end{array}$ & $\begin{array}{l}\text { \{Klasztor Sióstr Bernardynek } \\
\text { ul. Kielecka 2, Święta Katarzyna, } \\
\text { 26-010 Bodzentyn }\}\end{array}$ & $\begin{array}{l}\{\text { brak szczegóło- } \\
\text { wych danych }\end{array}$ \\
\hline 288 & Święty Krzyż & $\begin{array}{l}\text { Muzeum Historyczno-Misyjne Zgromadzenia } \\
\text { Misjonarzy Oblatów Maryi Niepokalanej } \\
\text { Święty Krzyż 1, 26-006 Nowa Słupia }\end{array}$ & $\begin{array}{l}\text { brak szczegółowych } \\
\text { danych }\end{array}$ \\
\hline 289 & Tarnobrzeg & $\begin{array}{l}\text { Muzeum Historyczne Miasta Tarnobrzega } \\
\text { (Zamek w Dzikowie) } \\
\text { ul. Sandomierska 27, 39-400 Tarnobrzeg }\end{array}$ & $\begin{array}{l}\text { brak szczegółowych } \\
\text { danych }\end{array}$ \\
\hline 290 & Tarnów & $\begin{array}{l}\text { Biblioteka Wyższego Seminarium Duchownego } \\
\text { ul. Piłsudskiego 6, 33-100 Tarnów }\end{array}$ & $\begin{array}{l}6224 \text { druków w } 5280 \\
\text { woluminach, w tym } \\
154 \text { inkunabuły } \\
(\text { w } 127 \text { woluminach) } \\
\text { (stan na } 2014 \text { rok) }^{321}\end{array}$ \\
\hline 291 & Tarnów & $\begin{array}{l}\text { Miejska Biblioteka Publiczna im. Juliusza } \\
\text { Słowackiego (Dział Starych Druków) } \\
\text { ul. Krakowska 4, 33-100 Tarnów }\end{array}$ & $\begin{array}{l}640 \text { druków w } 523 \\
\text { woluminach }^{322}\end{array}$ \\
\hline
\end{tabular}

$316 \mathrm{http} / / /$ kosciolpokoju.pl/biblioteka/?D=8.

317 Zob. http://www.zkpis.umk.pl/?w-klasztorze-siostr-dominikanek-zakonu-kaznodziejskiego-w-swietej-annie, 185.

318 Zob. https://bernardynkiklauzur.wixsite.com/swietakatarzyna/historia-swietej-katarzyny.

319 Muzea Kościoła katolickiego..., s. 131.

320 Kolekcja zawiera druki z dawnej Biblioteki Dzikowskiej. Według https://dzieje.pl/ dziedzictwo-kulturowe/starodruki-i-rekopisy-z-kolekcji-tarnowskich-na-wystawie-w-tarnobrzegu w zbiorach tych znajduje się 25 inkunabułów. Zob. też M. Sołtysiak, K. Wierzbicka, op. cit., s. 221; T. Zych, Kolekcja Dzikowska, zbiory hrabiów Tarnowskich, Tarnobrzeg 2019; https://mhmt. $\mathrm{pl} /$ zamek-tarnowskich/.

321 T. Kudroń, Biblioteka Wyższego Seminarium Duchownego w Tarnowie - dziedzictwo i nowa lokalizacja, „Forum Bibliotek Medycznych” 7, 2014, nr 2 (14), s. 195, http://digital.fides. org.pl/Content/1692/Kudron.pdf; J. Witczak, op. cit. Według Bibliotek Kościoła Katolickiego... (s. 125-126) w 2005 roku w zbiorach tych znajdowało się 5280 woluminów starych druków, w tym 127 woluminów inkunabułów. Zob. też http://www.wsd.tarnow.pl/43-bibilioteka/biblioteka.

322 Dane na podstawie kwerendy M. Kycler. Według https://www.biblioteka.tarnow.pl/zbiory liczba starych druków wynosi 522 woluminy. Z kolei B. Sawczyk (Skarby Miejskiej Biblioteki Publicznej im. Juliusza Stowackiego w Tarnowie w stulecie istnienia biblioteki, Tarnów 2008, s. 6) podaje, że w bibliotece liczba druków z XVI wieku wynosi 28 tytułów. Zob. też J.M. Marszalska, Katalog rękopisów i variów z dawnej rodowej biblioteki XX Sanguszków. (Fragment archiwum XX Sanguszków), Tarnów 1994; eadem, Najcenniejsze zabytki piśmiennictwa w zbiorach specjalnych MBP. Informator, Tarnów 1995; eadem, Polonica XVI-XVIII wieku w zbiorach Wojewódzkiej 


\begin{tabular}{|c|c|c|c|}
\hline 292 & Tarnów & $\begin{array}{l}\text { Muzeum Okręgowe w Tarnowie } \\
\text { Rynek 3, 33-100 Tarnów }\end{array}$ & $\begin{array}{l}\text { brak szczegółowych } \\
\text { danych }^{323}\end{array}$ \\
\hline$\{292\}$ & $\begin{array}{l}\{\text { Tomaszów } \\
\text { Mazowiecki\} }\end{array}$ & $\begin{array}{l}\text { \{Parafia Ewangelicko-Augsburska } \\
\text { ul. św. Antoniego 37/39, 97-200 Tomaszów } \\
\text { Mazowiecki\} }\end{array}$ & $\begin{array}{l}\{\text { brak szczegóło- } \\
\left.\text { wych danych }{ }^{324}\right\}\end{array}$ \\
\hline 293 & Toruń & $\begin{array}{l}\text { Archiwum Państwowe (Biblioteka) } \\
\text { pl. Rapackiego 4, 87-100 Toruń }\end{array}$ & $\begin{array}{l}131 \text { druków } \\
\text { w } 83 \text { woluminach } \\
\text { (stan na } 2002 \text { rok) }^{325}\end{array}$ \\
\hline 294 & Toruń & $\begin{array}{l}\text { Biblioteka Uniwersytetu Mikołaja Kopernika } \\
\text { (Sekcja Starych Druków) } \\
\text { ul. Gagarina 13, 87-100 Toruń }\end{array}$ & $\begin{array}{l}53412 \text { druków } \\
\text { (w } 39707 \text { wolumi- } \\
\text { nach), w tym } 137 \\
\text { inkunabułów (w } 104 \\
\text { woluminach) }\end{array}$ \\
\hline 295 & Toruń & $\begin{array}{l}\text { Dom Mikołaja Kopernika } \\
\text { ul. Kopernika 15/17, 87-100 Torú }\end{array}$ & $\begin{array}{l}\text { brak szczegółowych } \\
\text { danych }{ }^{327}\end{array}$ \\
\hline 296 & Toruń & $\begin{array}{l}\text { Książnica Kopernikańska/Wojewódzka Biblio- } \\
\text { teka Publiczna (Dział Zbiorów Specjalnych) } \\
\text { ul. Słowackiego 8, 87-100 Toruń }\end{array}$ & $\begin{array}{l}26294 \text { druków, } \\
\text { w tym } 75 \text { inkunabu- } \\
\text { łów }^{328}\end{array}$ \\
\hline
\end{tabular}

Biblioteki Publicznej w Tarnowie, Tarnów 1988; eadem, Polonica XVI-XVIII wieku. Katalog, Tarnów 1993; eadem, Stare druki obce XVI-XVIII wieku. Katalog, Tarnów 1996.

${ }^{323}$ Zob. http://www.dofe.fundusze.malopolska.pl/miasta/tarnow/muzeum-okregowe-w-tarnowie.

324 Zob. https://tomaszow.luteranie.pl/node/67.

325 K. Kopiński, J. Milewska-Kozłowska, Stare druki w bibliotece Archiwum Państwowego w Toruniu, „Folia Toruniensia” 2, 2002, s. 133-175, zwł. s. 134, http://kpbc.umk.pl/dlibra/ publication? $\mathrm{id}=24016$.

326 https://www.bu.umk.pl/stare_druki. Zob. wykaz literatury na temat tych zbiorów w: https://www.bu.umk.pl/literatura2; zob. też http://www.zkpis.umk.pl/?indywidualna-w-bibliotece-uniwersyteckiej-w-toruniu,167; L. Jarzębowski, F. Jurewicz, Polonika nie umieszczone w Bibliografii Polskiej Estreicherów. Starodruki, wiek XVI. Ze zbiorów Biblioteki Głównej UMK w Toruniu, „Zeszyty Naukowe Uniwersytetu Mikołaja Kopernika w Toruniu” 11, 1972, nr 2, s. 93-142. Katalog inkunabułów Biblioteki Uniwersyteckiej w Toruniu (oprac. M. Strutyńska, Toruń 1995, s. 7) odnotowuje 213 pozycji inkunabułów w 170 woluminach.

327 M. Sołtysiak, K. Wierzbicka, op. cit., s. 227; https://torun.wyborcza.pl/torun/1,35574, 11662235,Dom_Kopernika_zajal_sie_rola_kobiet_w_astronomii.html?disableRedirects=true.

328 Dane na podstawie kwerendy M. Kycler. Według http://ksiaznica.torun.pl/o-nas/zbiory/stare-druki-z-inkunabulami/ w bibliotece znajduje się 26306 tytułów starych druków, w tym 62 woluminy inkunabułów (73 pozycje). A. Lewandowska (Inkunabuły Książnicy Miejskiej im. M. Kopernika w Toruniu, Toruń 1979, s. 5) określała liczbę inkunabułów na 68 pozycji. Zob. też M. Curtze, Katalog der Bibliothek des Königl[ichen] Gymnasiums zu Thorn, T. 1, Nachtrag: 1871-1882, Thorn 1883; idem, Katalog der Bibliothek des Königl[ichen] Gymnasiums zu Thorn, T. 2, Nachtrag: 1883-1891, Thorn 1892; Katalog der Rathsbibliothek zu Thorn, Thorn 1896; A. Tujakowski, Wśród rękopisów i starodruków Ksiąznicy Miejskiej, „Rocznik Toruński” 2, 1967, s. 151-174; M. Strutyńska, Stare druki proweniencji gdańskiej w zbiorach Biblioteki UMK w Toruniu, „Libri Gedanenses” 13-14, 1995-1996, s. 219-222; K. Wyszomirska, Rękopiśmienne dedy- 


\begin{tabular}{|c|c|c|c|}
\hline 297 & Tropie & $\begin{array}{l}\text { Muzeum Parafialne } \\
\text { (filia Muzeum Diecezjalnego w Tarnowie) } \\
\text { Tropie 6, 33-316 Rożnów }\end{array}$ & $\begin{array}{l}\text { brak szczegółowych } \\
\text { danych }^{329}\end{array}$ \\
\hline 298 & Trzcianka & $\begin{array}{l}\text { Biblioteka Parafialna } \\
\text { (Parafia pw. św. Jana Chrzciciela) } \\
\text { ul. Żeromskiego 39, 64-980 Trzcianka }\end{array}$ & 2 druki 330 \\
\hline 299 & Trzcianka & $\begin{array}{l}\text { Muzeum Ziemi Nadnoteckiej } \\
\text { im. W. Stachowiaka } \\
\text { ul. S. Żeromskiego } 7 \text { i 36A, 64-980 Trzcianka }\end{array}$ & $\begin{array}{l}\text { brak szczegółowych } \\
\text { danych }^{331}\end{array}$ \\
\hline 300 & Trzebnica & $\begin{array}{l}\text { Dom Pielgrzyma/Muzeum Kultu św. Jadwigi } \\
\text { ul. Jana Pawła II 3, 55-100 Trzebnica }\end{array}$ & $\begin{array}{l}\text { brak szczegółowych } \\
\text { danych }^{332}\end{array}$ \\
\hline 301 & Tubądzin & $\begin{array}{l}\text { Muzeum Walewskich } \\
\text { (oddział Muzeum Okręgowego w Sieradzu) } \\
\text { Tubądzin 31A, 98-285 Tubądzin }\end{array}$ & $\begin{array}{l}\text { brak szczegółowych } \\
\text { danych } \\
\text { }^{333}\end{array}$ \\
\hline 302 & Tuchów & $\begin{array}{l}\text { Biblioteka Prowincjalna Redemptorystów } \\
\text { ul. Wysoka 1,33-170 Tuchów }\end{array}$ & $\begin{array}{l}\text { szacunkowo } 2007 \\
\text { woluminów, w tym } \\
2 \text { woluminy inkuna- } \\
\text { bułów, } 130 \text { druków } \\
\text { (w } 125 \text { woluminach) } \\
\text { z XVI wieku, } 380 \\
\text { woluminów z XVII } \\
\text { wieku, } 1317 \text { wolumi- } \\
\text { nów z XVIII wieku } \\
\text { oraz } 183 \text { woluminów } \\
\text { druków niedatowa- } \\
\text { nych }\end{array}$ \\
\hline
\end{tabular}

kacje autorskie ze zbiorów starodruków Wojewódzkiej Biblioteki Publicznej i Książnicy Miejskiej im. M. Kopernika w Toruniu, „Folia Toruniensia” 1, 2000, s. 31-51.

329 Zob. M. Sołtysiak, K. Wierzbicka, op. cit., s. 229; http://www.tropie.tarnow.opoka.org. $\mathrm{pl} /$ kosciol.htm.

330 E. Klessa, Biblioteka parafialna w Trzciance w latach 1983-2017, „Forum Bibliotek Medycznych" 10, 2017, $\mathrm{nr} 2$ (20), s. 105, http://digital.fides.org.pl/Content/1770/Klessa_2017_2.pdf.

331 M. Sołtysiak, K. Wierzbicka, op. cit., s. 230; https://www.eyca.pl/pl/znizki_i_korzysci/ wyszukiwarka_znizek?k=\&p=\&cty=\&c=CL00\&subc=\&page $=15$.

332 Muzea Kościoła katolickiego..., s. 142.

333 Znajduje się tam pewna liczba druków z XVI-XVIII wieku (częściowo z dawnej biblioteki dominikanów), zgromadzonych w dwóch szafach bibliotecznych — zob. http://polaneis.pl/miejsca/muzeum-walewskich-w-tubadzinie-lodzkie-portrety-w-roli-glownej; http://konkurs.eduseek. interklasa.pl/phobos/konkursy/konkurs2/k2-26/WWW/mwdwt.html; https://www.powiat-sieradz. $\mathrm{pl} /$ index.php/historia-i-kultura/2583-spuscizna-po-dominikanach-w-zbiorach-muzeum.

334 A. Karaś, Dzieje Biblioteki Prowincjalnej Redemptorystów w Tuchowie i ogólna charakterystyka księgozbioru, „Fides: Biuletyn Bibliotek Kościelnych” 1-2, 2010, s. 201-209. Według pracy magisterskiej D. Libery-Kolak z 1992 roku w bibliotece znajduje się 3350 starych druków (w tym 22 pochodzących z Tyńca), jednakże - jak wykazał A. Karaś — różnica ta bierze się z zaliczenia do tego zbioru również druków z XIX wieku. Liczba inkunabułów różni się również w pracach D. Libery-Kolak (3 druki) i M. Hutny z 2001 roku (2 egzemplarze). Zob. D. Libera- 


\begin{tabular}{|c|c|c|c|}
\hline 303 & Tyniec & $\begin{array}{l}\text { Biblioteka Opactwa Benedyktynów } \\
\text { ul. Benedyktyńska 37/39, Tyniec, } \\
\text { 30-375 Kraków }\end{array}$ & $\begin{array}{l}200 \text { woluminów } \\
\text { oraz nieliczne inku- } \\
\text { nabuły }{ }^{335}\end{array}$ \\
\hline 304 & Ustroń & $\begin{array}{l}\text { Muzeum Zbiory Marii Skalickiej } \\
\text { ul. } 3 \text { maja 68, 43-450 Ustroń Brzegi }\end{array}$ & $\begin{array}{l}\text { brak szczegółowych } \\
\text { danych }{ }^{336}\end{array}$ \\
\hline 305 & Wadowice & $\begin{array}{l}\text { Biblioteka Klasztoru Karmelitów Bosych } \\
\text { ul. Karmelicka 22, 34-100 Wadowice }\end{array}$ & $\begin{array}{l}7 \text { tysięcy wolumi- } \\
\text { nów } 337\end{array}$ \\
\hline 306 & Wadowice & $\begin{array}{l}\text { Wadowicka Biblioteka Publiczna } \\
\text { ul. Legionów 1, 34-100 Wadowice }\end{array}$ & 1 wolumin 338 \\
\hline 307 & Wałbrzych & $\begin{array}{l}\text { Muzeum Porcelany } \\
\text { ul. } 1 \text { maja } 9,58-300 \text { Wałbrzych }\end{array}$ & $\begin{array}{l}\text { ponad } 600 \text { dru- } \\
\text { ków }^{339}\end{array}$ \\
\hline 308 & Warszawa & $\begin{array}{l}\text { Archiwum Archidiecezjalne } \\
\text { ul. Dewajtis 3, 01-815 Warszawa }\end{array}$ & $\begin{array}{l}\text { brak szczegółowych } \\
\text { danych }\end{array}$ \\
\hline 309 & Warszawa & $\begin{array}{l}\text { Biblioteka „Bobolanum” } \\
\text { ul. Rakowiecka 61, 02-532 Warszawa }\end{array}$ & $\begin{array}{l}11300 \text { druków, } \\
\text { w tym } 10 \text { inkunabu- } \\
\text { lów }^{341}\end{array}$ \\
\hline
\end{tabular}

-Kolak, Biblioteka klasztoru Oo. Redemptorystów Tuchowie: jej dzieje i charakterystyka ogólna księgozbioru (praca magisterska), Uniwersytet Śląski, Katowice 1992; M. Hutny, Druki XV i XVII wieku w Bibliotece Prowincjonalnej Warszawskiej Prowincji Redemptorystów w Tuchowie (praca magisterska), Akademia Pedagogiczna im. Komisji Edukacji Narodowej, Kraków 2001. Według Bibliotek Kościoła Katolickiego... (s. 168) w 2005 roku zbiory te liczyły 1130 woluminów starych druków (nieopracowanych) oraz 2 woluminy inkunabułów. Zob. też E. Sękowska, Druki z XVII wieku z Biblioteki Prowincjonalnej Redemptorystów w Tuchowie (praca magisterska), Uniwersytet Pedagogiczny im. Komisji Edukacji Narodowej, Kraków 2010.

335 Biblioteki Kościoła Katolickiego..., s. 183; zob. też http://whk.up.krakow.pl/biblioteki/ tyniec/historia.html.

336 http://www.skalickamuzeum.pl/o-muzeum/wystawy-stale/; http://beskidslaski.pl/muzeum-zbiory-skalickiej/.

337 Biblioteki Kościoła Katolickiego..., s. 206. Według http://karmel-wadowice.pl/klasztor/ historia/ w zbiorach tych obecnie znajduje się „kilkaset starodruków”.

338 Dane na podstawie kwerendy M. Kycler.

$339 \mathrm{http} / / /$ walbrzych.naszemiasto.pl/artykul/wystawa-starodrukow-ze-zbiorow-walbrzyskiego-muzeum-zdjecia,747824,artgal,t,id,tm.html. Według http://www.zabytki.pl/sources/muzea/w/ walbrzych-okreg.html stan zbioru wynosi ponad 800 druków. Zob. też https://muzeum.walbrzych. $\mathrm{pl} / \mathrm{biblioteka/.}$

340 Zob. Archiwa Kościoła Katolickiego..., s. 104.

341 J. Witczak, op. cit. Według Bibliotek Kościoła Katolickiego... (s. 58, 195) w 2005 roku w zbiorach Biblioteki „Bobolanum” znajdowało się 11 tysięcy woluminów starych druków, w Bibliotece Pisarzy Towarzystwa Jezusowego (zlokalizowanej w tym samym budynku) zaś 2983 woluminy starych druków, w tym 10 woluminów inkunabułów (co łącznie powinno dawać 13983 woluminów starych druków, w tym 10 woluminów inkunabułów). Zob. też http://polishhistory. pl/biblioteki.html?\&tx_hmsbn_pi1\%5BshowUid\%5D=7764\&cHash=edffab9d71; R. Machnik, XVIII-wieczne druki wydane przez Jezuitów polskich w posiadaniu Biblioteki „Bobolanum” (praca licencjacka), „Bobolanum”, Warszawa 1967; R. Plezia, Druki nieznane lub niedokładnie opisane przez „Bibliografię Estreicherów” znajdujące się w Bibliotece Teologicznej „Bobolanum” (Polo- 


\begin{tabular}{|c|c|c|c|}
\hline 310 & Warszawa & $\begin{array}{l}\text { Biblioteka Główna Politechniki Warszawskiej } \\
\text { (Zbiory specjalne) } \\
\text { pl. Politechniki 1, 00-661 Warszawa }\end{array}$ & $\begin{array}{l}\text { brak szczegółowych } \\
\text { danych }^{342}\end{array}$ \\
\hline 311 & Warszawa & $\begin{array}{l}\text { Biblioteka Główna Uniwersytetu Kardynała } \\
\text { Stefana Wyszyńskiego } \\
\text { ul. Dewajtis 5, 01-815 Warszawa }\end{array}$ & $\begin{array}{l}934 \text { woluminy, } \\
\text { w tym } 2 \text { inkunabuły, } \\
68 \text { druków z XVI } \\
\text { wieku, } 318 \text { druków } \\
\text { z XVII wieku oraz } \\
528 \text { druków z XVIII } \\
\text { wieku }\end{array}$ \\
\hline 312 & Warszawa & $\begin{array}{l}\text { Biblioteka Główna Warszawskiego Uniwersy- } \\
\text { tetu Medycznego } \\
\text { ul. Żwirki i Wigury 63, 02-091 Warszawa }\end{array}$ & $\begin{array}{l}98 \text { woluminów } \\
(\text { stan na } 2016 \text { rok) })^{344}\end{array}$ \\
\hline 313 & Warszawa & $\begin{array}{l}\text { Biblioteka Instytutu Badań Literackich Polskiej } \\
\text { Akademii Nauk (Dział starodruków) } \\
\text { ul. Nowy Świat 72, 00-330 Warszawa }\end{array}$ & $\begin{array}{l}\text { co najmniej } 8 \text { tysię- } \\
\text { cy druków (z Biblio- } \\
\text { teki Michalskich) }\end{array}$ \\
\hline 314 & Warszawa & $\begin{array}{l}\text { Biblioteka Instytutu Slawistyki Polskiej Akade- } \\
\text { mii Nauk im. Zdzisława Stibera } \\
\text { ul. Krakowskie Przedmieście 26/28, } \\
\text { 00-927 Warszawa }\end{array}$ & 82 woluminy $^{346}$ \\
\hline 315 & Warszawa & $\begin{array}{l}\text { Biblioteka Muzeum i Instytutu Zoologii } \\
\text { Polskiej Akademii Nauk } \\
\text { ul. Wilcza 64, 00-679 Warszawa }\end{array}$ & 1272 druki $^{347}$ \\
\hline
\end{tabular}

nica XVIII w.) (praca licencjacka), „Bobolanum”, Warszawa 1967; L. Grzebień, Katalog starych druków Biblioteki Teologicznej „Bobolanum”: (polonica XVI w.) (praca licencjacka), „Bobolanum", Warszawa 1968); idem, Uzupetnienia do Bibliografii Estreicherów z Biblioteki Teologicznej Bobolanum w Warszawie, Lublin 1969 (nadb. z „Archiwa, Biblioteki i Muzea Kościelne” 19, 1969, s. 48-80); L. Zielińska, Księgozbiór starodruków świętolipskich w Bibliotece Bobolanum w Warszawie, [w:] Święta Lipka: perła na pograniczu ziem, kultur i wyznań, red. A. Jacyniak, Warszawa 2008, s. 88-91.

$342 \mathrm{http} / / /$ www.bg.pw.edu.pl/index.php/zasoby.

$343 \mathrm{http} / / /$ www.biblioteka.uksw.edu.pl/pl/node/27; http://www.biblioteka.uksw.edu.pl/pl/ node/186. Z wymienionego podziału starych druków szacunkowo powinno być ich 916, choć jednocześnie na tej konkretnej podstronie widnieje informacja, że w biblioteka posiada „dwa inkunabuły i około tysiąca starych druków". Z kolei według http://bip.uksw.edu.pl/node/7 oraz Bibliotek Kościoła Katolickiego... (s. 46) zbiór ten liczy 929 woluminów starych druków, w tym 2 inkunabuły. Zob. też P. Skalski, Kryteria doboru starych druków do konserwacji w Bibliotece Uniwersytetu Kardynata Stefana Wyszyńskiego, „Fides: Biuletyn Bibliotek Kościelnych” 22, 2016, nr 1, s. 49-60, http://digital. fides.org.pl/dlibra/docmetadata?id=1760.

$344 \mathrm{https} / / /$ biblioteka.gumed.edu.pl/kdbaum/?print $=6$.

345 https://prenumeruj.forumakademickie.pl/fa/2017/12/michalscy/. W zbiorze wyróżniają się „bardzo cenne broszury z okresu Sejmu Wielkiego i Insurekcji Kościuszkowskiej” — zob. http:/ibl. waw.pl/pl/o-instytucie/biblioteka/o-bibliotece-ibl. Zob. też http://ibl.waw.pl/pl/repozytoria.

$346 \mathrm{http} / / /$ ispan.waw.pl/default/pl/biblioteka.

347 https://miiz.waw.pl/pl/zbiory-biblioteczne. 


\begin{tabular}{|c|c|c|c|}
\hline 316 & Warszawa & $\begin{array}{l}\text { Biblioteka Muzeum Literatury } \\
\text { im. Adama Mickiewicza } \\
\text { Rynek Starego Miasta 20,00-272 Warszawa }\end{array}$ & $\begin{array}{l}\text { brak szczegółowych } \\
\text { danych }\end{array}$ \\
\hline 317 & Warszawa & $\begin{array}{l}\text { Biblioteka Muzeum Narodowego } \\
\text { Al. Jerozolimskie 3, 00-495 Warszawa }\end{array}$ & $\begin{array}{l}2800 \text { druków w } 3587 \\
\text { woluminach, w tym } \\
13 \text { inkunabułów }^{349}\end{array}$ \\
\hline 318 & Warszawa & $\begin{array}{l}\text { Biblioteka Narodowa } \\
\text { (Zakład Starych Druków) } \\
\text { Pałac Rzeczypospolitej, pl. Krasińskich 3/5, } \\
\text { 00-001 Warszawa }\end{array}$ & $\begin{array}{l}162415 \text { wolumi- } \\
\text { nów, w tym około } \\
1200 \text { inkunabułów } \\
\text { (w blisko } 1 \text { tysią- } \\
\text { cu woluminów), } \\
\text { około } 13 \text { tysięcy } \\
\text { druków (w mniej } \\
\text { więcej } 10 \text { tysią- } \\
\text { cach woluminów) } \\
\text { z XVI wieku, około } \\
50 \text { tysięcy druków } \\
\text { (w blisko } 34 \text { tysią- } \\
\text { cach woluminów) } \\
\text { z XVII wieku, około } \\
90 \text { tysięcy druków } \\
\text { (w około } 100 \text { tysią- } \\
\text { cach woluminów) } \\
\text { z XVIII wieku, oko- } \\
\text { ło } 7 \text { tysięcy wolu- } \\
\text { minów periodyków } \\
\text { z XVI-XVIII wieku } \\
\text { (stan na } 31 \text { stycznia } \\
2014 \text { roku) } 350\end{array}$ \\
\hline
\end{tabular}

348 Według M. Sołtysiak i K. Wierzbickiej (op. cit., s. 246) biblioteka posiada druki od XV do XX wieku. Zob. też http://muzeumliteratury.pl/dzialy/biblioteka/; https://www.subiektywnieoksiazkach.pl/2016/07/muzeum-literatury-im-adama-mickiewicza.html.

349 https://www.mnw.art.pl/kolekcje/zbiory-studyjne/zbiory-biblioteki/kolekcja-starodrukow/.

350 https://www.bn.org.pl/o-nas/zbiory-bn/zbiory/stare-druki. Polonika stanowią prawie jedną trzecią druków z XVI wieku, ponad jedną trzecią druków z XVII wieku oraz mniej niż połowę druków z XVIII wieku. Zob. też https://www.bn.org.pl/o-nas/zbiory-bn/zbiory/stare-druki/katalogi-i-kartoteki; https://www.bn.org.pl/o-nas/zbiory-bn/zbiory/stare-druki/historia-zbiorow; Dokumenty dotyczace akcji delegacyj polskich w Komisjach Mieszanych Reewakuacyjnej i Specjalnej w Moskwie, z. 1-9, Warszawa 1922-1924; S. Demby, Biblioteka Narodowa w Warszawie, wyd. 2 uzup., Warszawa 1930; A. Kawecka, Biblioteka Narodowa w Warszawie, Warszawa 1934; Biblioteka Narodowa w latach 1945-1956, Warszawa 1958; A. Kawecka-Gryczowa, Ochrona zbiorów Biblioteki Narodowej, [w:] Walka o dobra kultury, T. 1, Warszawa 1970, s. 179-242; P. Buchwald-Pelcowa, Zaktad Starych Druków i Ośrodek Opieki nad Dawna Ksiązką, [w:] Księga jubileuszowa Biblioteki Narodowej, Warszawa 1984, s. 159-176; J. Rudnicka, Biblioteka Wilanowska, Warszawa 1967; P. Buchwald-Pelcowa, Inkunabuly i stare druki z Biblioteki Ordynacji Zamojskiej w Bibliotece Narodowej, „Biuletyn Informacyjny Biblioteki Narodowej” 2, 1999, s. 15-17; eadem, Od „Prognostyku na rok 1501” do dokumentu sporów sq̨dowych Wereszczaków z Mickiewicza-

\section{ROCZNIKI BIBLIOTECZNE}

ROK LXIII, 2019

(C) for this edition by CNS 


\begin{tabular}{|c|l|l|l|}
\hline 319 & Warszawa & $\begin{array}{l}\text { Biblioteka Publiczna m.st. Warszawy/Bibliote- } \\
\text { ka Główna Województwa Mazowieckiego } \\
\text { (Dział Starych Druków i Rękopisów) } \\
\text { ul. Koszykowa 26/28, 00-950 Warszawa }\end{array}$ & $\begin{array}{l}\text { około 14 340 wolu- } \\
\text { minów 351 }\end{array}$ \\
\hline 320 & Warszawa & $\begin{array}{l}\text { Biblioteka Sejmowa (Muzealia) } \\
\text { ul. Wiejska 4/6/8, 00-902 Warszawa }\end{array}$ & $\begin{array}{l}\text { 644 druki (797 wo- } \\
\text { luminów) (stan na } \\
1993 \text { rok) }\end{array}$ \\
\hline 321 & Warszawa & $\begin{array}{l}\text { Biblioteka Seminarium Metropolitalnego } \\
\text { Archidiecezji Warszawskiej } \\
\text { ul. Krakowskie Przedmieście 52/54, } \\
\text { 00-322 Warszawa }\end{array}$ & $\begin{array}{l}58 \text { tysięcy druków, } \\
\text { w tym 158 inkuna- } \\
\text { bułów }^{353}\end{array}$ \\
\hline 322 & Warszawa & $\begin{array}{l}\text { Biblioteka Szkoły Głównej Handlowej } \\
\text { ul. Rakowiecka 22B, 02-521 Warszawa }\end{array}$ & $\begin{array}{l}\text { ponad 4 tysiące } \\
\text { woluminów }\end{array}$ \\
\hline
\end{tabular}

$m i$, „Biuletyn Informacyjny Biblioteki Narodowej” 1, 2001, s. 17-21; Katalog druków cyrylickich XV-XVIII wieku w zbiorach Biblioteki Narodowej, oprac. Z. Żurawińska, Z. Jaroszewicz-Pieresławcew, Warszawa 2004.

351 Dane na podstawie kwerendy M. Kycler. Według http://www.koszykowa.pl/dla-czytelnikow/czytelnie-i-uslugi/6-czytelnie/czytelnia-starych-drukow-i-rekopisow/22 liczba starych druków wynosi około 15 tysięcy woluminów. Zob. też Katalog starych druków Biblioteki Publicznej m.st. Warszawy, cz. 1. Inkunabuty, oprac. A. Kawecka-Gryczowa, Warszawa 1949; Katalog starych druków Biblioteki Publicznej m.st. Warszawy, cz. 2. Polonica XVI wieku, oprac. A. Kawecka-Gryczowa, Warszawa 1957; Katalog starych druków Biblioteki Publicznej m.st. Warszawy, cz. 3, Polonica XVII wieku, oprac. J. Rudnicka, Warszawa 1976; Historyczne księgozbiory warszawskie, cz. 1, oprac. J. Jagielska, Warszawa 1995; Historyczne księgozbiory warszawskie, cz. 2, oprac. J. Jęśko, Warszawa 1996; M. Parnowska, Warszawskie kolekcje historyczne w zbiorach Działu Starych Druków i Rękopisów Biblioteki Publicznej m. st. Warszawy, [w:] Historyczne księgozbiory warszawskie, cz. 2, oprac. J. Jęśko, Warszawa 1996; Katalog starych druków Biblioteki Publicznej m.st. Warszawy. Inkunabuły, oprac. A. Kawecka-Gryczowa, M. Spandowski, wyd. 2, Warszawa 2005; Czasopisma warszawskie XVII-XIX wieku w zbiorach Biblioteki Publicznej m. st. Warszawy. Katalog, oprac. G.M. Lewandowska, Warszawa 2007; Spuścizna Stanisława Leszczyńskiego w zbiorach Biblioteki Publicznej m.st. Warszawy, oprac. R. Nowoszewski, Warszawa 2007; M. Parnowska, A. Komornicka, O ksiażkach Ludwika Perzyny, [w:] Darczyńcy i ich kolekcje w zbiorach Biblioteki na Koszykowej, red. A. Komornicka, M. Parnowska, Warszawa 2008.

$352 \mathrm{~W}$ zbiorze tym 60 dzieł to druki obce, polonika nienotowane w BP Estreicherów - 29 dzieł, a 497 dzieł (649 egzemplarzy) to druki dotyczące Sejmu i prawa — zob. H. Mieczkowska, Sejm i prawo w starych drukach Biblioteki Sejmowej: katalog, red. nauk. A. Mężyński, Warszawa 1993, s. 5. Zob. też http://biblioteka.sejm.gov.pl/zbiory_muzealia/.

353 J. Witczak, op. cit. Według Bibliotek Kościoła Katolickiego... (s. 127) w 2005 roku w zbiorach tych znajdowały się 53 tysiące woluminów starych druków. Zob. też https://biblioteka. wmsd.waw.pl/; http://kbn.icm.edu.pl/pub/kbn/sn/archiwum/9602/2003pos.html; W. Kwiatkowski, Biblioteka Archidiecezjalna przy Seminarium św. Jana w Warszawie, Warszawa 1938.

354 H. Długołęcka, Starodruki Biblioteki Szkoły Głównej Handlowej w Warszawie, Warszawa 2017, s. 6; por. http://www.wydawnictwo.sgh.waw.pl/produkty/profilProduktu/id/972/STARODRUKI_BIBLIOTEKI_SZKOLY_GLOWNEJ_HANDLOWEJ_W_WARSZAWIE_Hanna_Dlugolecka/. Zob. też http://biblioteka.sgh.waw.pl/pl/Starodruki/Strony/default.aspx. 


\begin{tabular}{|c|l|l|l|}
\hline 323 & Warszawa & $\begin{array}{l}\text { Biblioteka Uniwersytecka } \\
\text { (Gabinet Starych Druków) } \\
\text { ul. Dobra 56/66, 00-312 Warszawa } \\
\text { Stopniowo przejmowane są (jako depozyt) stare } \\
\text { druki z bibliotek wydziałowych i instytuto- } \\
\text { wych Uniwersytetu Warszawskiego }\end{array}$ & $\begin{array}{l}\text { ponad 130 tysięcy } \\
\text { woluminów, w tym } \\
145 \text { inkunabułów } \\
\text { (w 119 woluminach), } \\
\text { ponad 12 tysięcy } \\
\text { druków z XVI wieku } \\
\text { oraz około 5 tysięcy } \\
\text { woluminów czaso- } \\
\text { pism i kalendarzy } 355\end{array}$ \\
\hline
\end{tabular}

355 Książki obce z XVI-XVIII wieku stanowią około 75\% zawartości zbiorów; około 12 tysięcy druków pochodzi z dawnej Biblioteki Załuskich — zob. https://www.buw.uw.edu.pl/zbiory-specjalne/gabinet-starych-drukow/; W.M. Rudzińska, Biblioteka Uniwersytecka w Warszawie, skarbnica nauki i sztuki - zbiory specjalne w Bibliotece Uniwersyteckiej W Warszawie, [w:] Zbiory Specjalne i regionalia w polskich bibliotekach naukowych i publicznych. Materiały z III Ogólnopolskiej Konferencji Naukowej zorganizowanej przez Bibliotekę Główna Uniwersytetu Szczecińskiego 9-11 września 2009, red. R. Gaziński, Szczecin 2010, s. 65, http://zbc.ksiaznica.szczecin. $\mathrm{pl} /$ Content/21798/Seria\%20BPZ\%20T\%20VII.pdf. W.M. Rudzińska (ibidem) podaje nieco odmienne szacunki co do druków z XV wieku, to jest: „143 inkunabuły w 147 woluminach”. Zob. też. S.J. Siennicki, Les Elzevir de la Bibliotheque de l'Université Impériale de Varsovie, Varsovie 1874; idem, Recueil des éditions des imprimeurs célebres de l'Italie, de la France et de la Belgique, conservées dans la Bibliotheque de l'Université Impériale de Varsovie, Varsovie 1878; T. Wierzbowski, Bibliographia Polonica XV ac XVI ss., T. 1. Opera et editiones, quae in Bibliotheca Caesareae Varsoviensis asservantur, Varsovie 1889; M. Łodyński, Bibljoteka Szkoty Rycerskiej, Warszawa 1930; Z. Nowakowski, Biblioteka dawnego Banku Polskiego 1828-1885, Warszawa 1936; W. Stummer, Biblioteka Sadu Apelacyjnego w Warszawie 1810-1865, „Roczniki Biblioteczne” 2, 1958, nr 3-4, s. 431-425; M. Brykalska, Księgozbiór Arkadego Tołoczanowa w BUW, „Roczniki Biblioteczne" 3, 1959, nr 1-4, s. 97-164; T. Strzembosz, Jan Strzembosz (1545-1606), jego rękopis i zbiór, „Roczniki Biblioteczne” 3,1959, nr 3-4, s. 401-423; A. Mrozowska, Najstarsze druki orientalne w zbiorach Biblioteki Uniwersyteckiej w Warszawie, Warszawa 1962; M. Sipayłło, Z starych ksiażek, „Odrodzenie i Reformacja w Polsce” 11, 1966, s. 147-159; idem, Z starych książek. II. Forma revocoviana Andrzeja z Brzezia Chrzastowskiego, „Odrodzenie i Reformacja w Polsce" 12, 1967, s. 199-222; Z. Rutkowski, Kartki z dziejów bibliotek wojskowych. Dla upamiętnienia dwóchsetlecia polskich bibliotek wojskowych 1767-1967, Warszawa 1967; M. Sipayłło, Fata libellorum, „Rocznik Biblioteki Narodowej” 4, 1968, s. 253-263; O. Błażejewicz, Księgozbiór szlachecki Kazimierza Chromińskiego z okresu Oświecenia, „Roczniki Biblioteczne” 15, 1971, nr 3-4, s. 1-18; H. Domańska, Z dziejów Biblioteki Kodeńskiej Sapiehów, „Z Badań nad Polskimi Księgozbiorami Historycznymi” 1, 1975, s. 97-126; M. Brzdękiewicz, Księgozbiór Aleksandra Benedykta Batowskiego, „Z Badań nad Polskimi Księgozbiorami Historycznymi” 1, 1975, s. $127-$ 146; H. Juszczakowska, $Z$ badań nad załuscianami w Bibliotece Uniwersytetu Warszawskiego, „Z Badań nad Polskimi Księgozbiorami Historycznymi” 2, 1976, s. 35-76; O. Błażejewicz, W kręgu Biblioteki Załuskich. Bibliofilstwo Kazimierza Chromińskiego, „Z Badań nad Polskimi Księgozbiorami Historycznymi" 2, 1976, s. 77-111; M. Cubrzyńska-Leonarczyk, Sztuka typograficzna dawnej Warszawy, Warszawa 1978; O. Błażejewicz, Biblioteka Liceum Warszawskiego, „,Roczniki Biblioteczne" 23, 1979, nr 2, s. 53-92; I. Łukijaniuk, Biblioteka Marcina i Wawrzyńca Goślickich, „Z Badań nad Polskimi Księgozbiorami Historycznymi” 6, 1981, s. 167-197; Sobiesciana w zbiorach Biblioteki Uniwersyteckiej w Warszawie, [rękopisy i stare druki oprac. M. Cubrzyńska-Leonarczyk], Warszawa 1983; E. Truskolaska, Nieznana dedykacja Stanistawa Lubienieckiego, „Rocz- 
niki Biblioteczne" 28, 1984, nr 1-2, s. 377-383; K. Niklewiczówna, Oddziat Starych Druków Biblioteki Uniwersyteckiej w Warszawie, „Z Badań nad Polskimi Księgozbiorami Historycznymi" 8, 1985, s. 5-60; U. Paszkiewicz, Ksiegozbiór Stanisława Staszica w Bibliotece Uniwersyteckiej w Warszawie. Studium proweniencyjne, „Z Badań nad Polskimi Księgozbiorami Historycznymi" 9, 1986, s. 79-124; E. Rose, Księgozbiór Józefa Kalasantego Szaniawskiego zachowany w Bibliotece Uniwersyteckiej w Warszawie, „Z Badań nad Polskimi Księgozbiorami Historycznymi" 10, 1988, s. 33-61; M. Sipayłło, Polskie superexlibrisy XVI-XVIII wieku w zbiorach Biblioteki Uniwersytetu Warszawskiego, Warszawa 1988; J. Wojakowski, Biblioteka Królewskiego Korpusu Kadetów w Warszawie, Warszawa 1989; S. Rybandt, Superekslibrisy prymasa Stanistawa Karnkowskiego w Bibliotece Uniwersyteckiej w Warszawie, „Z Badań nad Polskimi Księgozbiorami Historycznymi" 11, 1991, s. 5-26; eadem, Księgozbiór szkoty pijarskiej i popijarskiej z Radomia w zbiorach Biblioteki Uniwersyteckiej w Warszawie, ,Z Badań nad Polskimi Księgozbiorami Historycznymi" 12, 1992, s. 55-94; S. Rybandt, Ksiegozbiór prymasa Stanisława Karnkowskiego, źródło badań nad kultura umysłowa dostojnika kościelnego XVI w., „Z Badań nad Polskimi Księgozbiorami Historycznymi” 13, 1992, s. 117-130; E. Truskolaska, Burmistrz siedemnastowiecznej Warszawy Karol Zabrzeski i jego księgozbiór, „Z Badań nad Polskimi Księgozbiorami Historycznymi” 15, 1993, s. 121-154, eadem, Burmistrz siedemnastowiecznej Warszawy Karol Zabrzeski i jego księgozbiór, cz. 2. Katalog, „Z Badań nad Polskimi Księgozbiorami Historycznymi" 17, 1996, s. 127-289; Katalog druków XV i XVI wieku w zbiorach Biblioteki Uniwersyteckiej w Warszawie, T. 1-8, red. T. Komender, H. Mieczkowska, Warszawa 1994-2018; M. Czapnik, Bożogrobca Stanisław z Łowicza i jego księgozbiór, „Z Badań nad Polskimi Księgozbiorami Historycznymi" 17, 1996, s. 17-49; E. Truskolaska, Ob odnoj knige iz biblioteki I.I. Suvalova (k istorii pol'sko-russkich bibliofil'skich kontaktov epochi Prosveščenija), [w:] Rukopisy, redkie izdanija, archivy, iz fondov biblioteki Moskovskogo universiteta, Moskva 1997, s. 71-80; M. Cubrzyńska-Leonarczyk, Germanika w zbiorach Biblioteki Uniwersyteckiej w Warszawie, „Z Badań nad Polskimi Księgozbiorami Historycznymi” 18, 1997, s. 147-173; E. Bylina, H. Mieczkowska, Oddziat Starych Druków 1949-1980, [w:] Biblioteka Uniwersytecka w Warszawie w latach 19451980, Warszawa 1998, s. 269-285; M. Cubrzyńska-Leonarczyk, Universitätsbibliothek Warschau, [w:] Handbuch deutscher historischer Buchbestände in Europe, T. 6. Polen, oprac. M. Zacharska et al., Hildesheim 1999, s. 61-71; eadem, Polonica zagraniczne - stare druki, [w:] Zbiory polonijne Biblioteki Uniwersyteckiej $w$ Warszawie $i$ wybranych bibliotek instytutowych Uniwersytetu Warszawskiego: informator, [całość oprac. J. Ćwiekowa et al.], Warszawa 1999, s. 23-36; eadem, Polskie superekslibrisy XVI-XVIII wieku w zbiorach Biblioteki Uniwersytetu Warszawskiego. Centuria druga, Warszawa 2001; eadem, Kanonik warszawski Jan Chociszewski (1572-1617) i jego ksiegozbiór, „Roczniki Biblioteczne” 46, 2002, s. 177-195; A. Cetera, M. Czapnik, M. Grzegorzewska, Szekspirowski apokryf (Egzemplarz „The Landgrave of Hessen... [1596] Edwarda Moningsa w zbiorach Biblioteki Uniwersyteckiej w Warszawie), „Przegląd Humanistyczny” 47, 2003, nr 1, s. 71-87; Piękne-rzadkie-cenne. Katalog wystawy. Druki XVIII w. [dokument elektroniczny], oprac. H. Mieczkowska [et al.], Warszawa 2003; Piękne-rzadkie-cenne. Katalog wystawy. Druki XVi XVI w. [dokument elektroniczny], oprac. M. Czapnik [et al.], Warszawa 2005; Piękne-rzadkie-cenne. Katalog wystawy. Druki XVII w. [dokument elektroniczny], oprac. M. Cubrzyńska-Leonarczyk, K. Opalińska, Warszawa 2005; A. Cetera, M. Grzegorzewska, Fatszerstwo prawie doskonate (Marginalia Williama Irelanda w ksiażce Edwarda Moningsa „The Landgrave of Hessen... [1596] w zbiorach Biblioteki Uniwersyteckiej w Warszawie), „Przegląd Humanistyczny” 48, 2004, $\mathrm{nr}$ 4, s. 133-143; E. Bylina, Renesansowy księgozbiór rodziny Strzemboszów, [w:] Księgozbiory szlacheckie XVI-XVII wieku, Warszawa 2004; K. Opalińska, Instygator koronny Andrzej Lisiecki i jego ksiegozbiór, [w:] Ksiegozbiory szlacheckie...; E. Truskolaska, Księozbiór bożogrobców miechowskich w Bibliotece Uniwersyteckiej w Warszawie, „Archiwa, Biblioteki i Muzea Kościel- 


\begin{tabular}{|c|l|l|l|}
\hline 324 & Warszawa & $\begin{array}{l}\text { Biblioteka Wydziału Architektury Politechniki } \\
\text { Warszawskiej } \\
\text { ul. Koszykowa 55, parter, pokój 2, } \\
\text { 00-659 Warszawa }\end{array}$ & $\begin{array}{l}\text { brak szczegółowych } \\
\text { danych }^{356}\end{array}$ \\
\end{tabular}

ne" 81, 2004, s. 353-369; M. Czapnik, Edward Monings's account of a visit to Hessen and the forgery of the „Shakespeare Library”, „Polish Libraries Today” 6, 2005, s. 52-56; H. Mieczkowska, Ełk-Królewiec-Warszawa. Z dziejów unikatowych egzemplarzy Biblioteki Uniwersyteckiej w Warszawie, „Rocznik Biblioteki Narodowej” 37-38, 2006, s. 95-104; M. Czapnik, Ksiegozbiór ks. Jana Bogusławskiego świadectwem zainteresowań cysterskiego kaznodziei i tłumacza, ,Roczniki Biblioteczne" 53, 2009, s. 147-172; I. Wiencek, O Pindarze i jego czytelnikach. Egzemplarz XVI-wiecznej edycji ze zbiorów BUW z rękopiśmiennymi zapiskami Ae. P. z Heidelbergu, „Studia Źródłoznawcze" 46, 2009, s. 1-27; M. Czapnik, Księgozbiór Krzysztoporskich. Z dziejów renesansowych bibliotek szlacheckich, [w:] Ksiegozbiory szlacheckie XVI-XVII wieku, T. 2, Warszawa 2009; K. Opalińska, Szlachta różnowiercza i pozostałości po jej księgozbiorach w zbiorach BUW (XVI w.), [w:] Ksiegozbiory szlacheckie..., T. 2; E. Bylina, Z dziejów biblioteki kanoników regularnych lateraneńskich w Mstowie: druki XVI wieku w BUW, ,Z Badań nad Książką i Księgozbiorami Historycznymi" 3, 2009, s. 55-64; I. Wiencek, Wydarte, zamazane, zaszyte - cenzura w bibliotekach klasztornych (na przykładzie druków XVI-XVII w. ze zbiorów Biblioteki Uniwersyteckiej w Warszawie), [w:] Czytanie, czytelnictwo, czytelnik, red. A. Żbikowska-Migoń, przy współpr. A. Luszpak, Wrocław 2011, s. 349-368; M. Czapnik, Böcker från andra sidan havet. Äldre tryckta skrifter med svensk proveniens $i$ universitetsbiblioteket $i$ Warszawa [Ksiażki zza morza - stare druki proweniencji szwedzkiej w zbiorach Biblioteki Uniwersyteckiej w Warszawie, przeł. A. Wolodarski], „Biblis” 60, sek 125, 2012-2013, s. 2-25; H. Mieczkowska, Szesnastowieczne bohemica w zbiorach Biblioteki Uniwersyteckiej w Warszawie, [w:] Libri magistri muti sunt: pocta Jaroslave Kasparove, red. A. Cisarova Smitkova, A. Jelinkova, M. Svobodova, Praha 2013, s. 133-151; I. Wiencek, O cenzurowaniu ksiag $w$ dawnych bibliotekach klasztornych, „Hereditas Monasteriorum" 2013, nr 2, s. 195-218, http://issuu.com/hereditas monasteriorum/docs/artykul10/24; M. Czapnik, Druki proweniencji szwedzkiej w ksiegozbiorze warszawskiej ksiażnicy uniwersyteckiej, „Z Badań nad Książką i Księgozbiorami Historycznymi” 7-8, 2013-2014, s. 267-273; E. Bylina, Pocysterskie ksiegozbiory z Koprzywnicy, Sulejowa i Wachocka w zbiorach Biblioteki Uniwersyteckiej w Warszawie, [w:] Kasaty klasztorów na obszarze dawnej Rzeczypospolitej Obojga Narodów i na Ślasku na tle procesów sekularyzacyjnych w Europie, T. 3, Wrocław 2014, s. 185203; M. Czapnik, Ksiegozbiory klasztorów w Lowiczu i ich pokasacyjne losy, [w:] Kasaty klasztorów..., s. 205-220; I. Wiencek, O jezuicie Andrzeju Obrębskim (ok. 1567-1639). Przyczynek do dziejów klasztornej cenzury bibliotecznej, „Studia Źródłoznawcze” 52, 2014, s. 73-89; E. Bylinowa, Samuel Bogumit Linde - scenariusz wystawy, [w:] Bibliotheca Lindiana. Samuel Bogumit Linde (1771-1847) pierwszy dyrektor Biblioteki Uniwersyteckiej w Warszawie. W 165. rocznice śmierci, red. M. Cubrzyńska-Leonarczyk, Warszawa 2015, s. [273]-299; M. Czapnik, Ksiażkowe znaki własnościowe $i$ ich znaczenie dla ochrony zbiorów przed kradzieża, „Bibliotheca Nostra. Śląski Kwartalnik Naukowy" 2015, nr 4; eadem, Oprawy druków poznańskiego Monogramisty MC, [w:] Tegumentologia polska dzisiaj. Polish Bookbindings Studies Today, Toruń 2015, s. 133164; H. Mieczkowska, „Osobliwość nieznana”. Zakupy starych druków w Bibliotece Publicznej przy Królewskim Uniwersytecie Warszawskim, Warszawa 2015, s. 83-99.

356 Zob. https://www.arch.pw.edu.pl/Studia/Biblioteka. 


\begin{tabular}{|c|c|c|c|}
\hline 325 & Warszawa & $\begin{array}{l}\text { Biblioteka Wyższego Seminarium Duchownego } \\
\text { Diecezji Warszawsko-Praskiej } \\
\text { ul. Mehoffera 2, 03-131 Warszawa-Tarchomin }\end{array}$ & $\begin{array}{l}\text { ponad } 100 \text { dru- } \\
\text { ków }^{357}\end{array}$ \\
\hline 326 & Warszawa & $\begin{array}{l}\text { Biblioteka Zamku Królewskiego } \\
\text { pl. Zamkowy 4, 00-277 Warszawa }\end{array}$ & 2500 druków $^{358}$ \\
\hline 327 & Warszawa & $\begin{array}{l}\text { Centralna Biblioteka Geografii i Ochrony } \\
\text { Środowiska Polskiej Akademii Nauk } \\
\text { (Zbiory specjalne) } \\
\text { ul. Twarda 51/55, 00-818 Warszawa }\end{array}$ & $\begin{array}{l}\text { brak szczegółowych } \\
\text { danych }^{359}\end{array}$ \\
\hline 328 & Warszawa & $\begin{array}{l}\text { Centralna Biblioteka Rolnicza im. Michała } \\
\text { Oczapowskiego } \\
\text { Krakowskie Przedmieście 66, } \\
\text { 00-950 Warszawa }\end{array}$ & 828 woluminów $^{360}$ \\
\hline 329 & Warszawa & $\begin{array}{l}\text { Centralna Biblioteka Wojskowa im. Marszałka } \\
\text { Józefa Piłsudskiego (Dział Zbiorów Specjalnych) } \\
\text { ul. Ostrobramska 109, 04-041 Warszawa }\end{array}$ & $\begin{array}{l}3 \text { tysiące druków } \\
\text { (stan na } 2009 \text { rok- } \\
\text { aktualizacja w } 2016 \\
\text { roku) }\end{array}$ \\
\hline 330 & Warszawa & $\begin{array}{l}\text { Czytelnia Naukowa nr } 1 \text { (Biblioteka Publiczna } \\
\text { w Dzielnicy Targówek m.st. Warszawy) } \\
\text { ul. św. Wincentego 85, 03-291 Warszawa }\end{array}$ & kilka druków ${ }^{362}$ \\
\hline 331 & Warszawa & $\begin{array}{l}\text { Główna Biblioteka Lekarska } \\
\text { im. Stanisława Konopki } \\
\text { (Dział Starej Książki Medycznej/Zbiorów } \\
\text { Specjalnych) } \\
\text { ul. Jazdów 1A, 00-467 Warszawa }\end{array}$ & $\begin{array}{l}\text { około } 4 \text { tysiące } \\
\text { woluminów, w tym } \\
5 \text { inkunabułów } \\
\text { (stan na } 2014 \text { rok) })^{363}\end{array}$ \\
\hline 332 & Warszawa & $\begin{array}{l}\text { Główny Urząd Miar (Biblioteka) } \\
\text { ul. Elektoralna 2, 00-139 Warszawa }\end{array}$ & $\begin{array}{l}1 \text { druk z XVIII } \\
\text { wieku }^{364}\end{array}$ \\
\hline
\end{tabular}

357 http://wsddwp.edu.pl/o-bibliotece/. Według Bibliotek Kościoła Katolickiego... (s. 129) w 2005 roku w zbiorach tych znajdowało się 21 woluminów starych druków.

358 https://www.zamek-krolewski.pl/biblioteka.

359 http://www.cbgios.pan.pl/specjalizacja-zbiorow.html.

$360 \mathrm{http} / / / \mathrm{cbr}$. gov.pl/index.php/o-bibliotece.html.

361 https://dzieje.pl/aktualnosci/90-lat-centralnej-biblioteki-wojskowej; https://pl.wikipedia. org/wiki/Centralna_Biblioteka_Wojskowa.

$362 \mathrm{http} / / /$ www.czarniecki.edu.pl/joomla/index.php/o-nas/partnerzy.

363 J. Kapuścik, Główna Biblioteka Lekarska - wczoraj i dziś, „Przegląd Biblioteczny” 1, 1996, s. 30, http://medioteka.uw.edu.pl/Content/2481/p1996_1_03.pdf; W. Giermaziak, M. Kulesza, Dziat Zbiorów Specjalnych Głównej Biblioteki Lekarskiej im. Stanisława Konopki w Warszawie (1995-2013), „Forum Bibliotek Medycznych” 7, 2014, nr 1 (13), s. 376-377, http://cybra. lodz.pl/Content/11295/373_FBM_2014_1.pdf; zob. też M. Sołtysiak, K. Wierzbicka, op. cit., s. 261.

364 Rozmowa telefoniczna oraz korespondencja e-mailowa z bibliotekarzem GUM panią Agnieszką Fietkiewicz-Zapalską z 6 grudnia 2019 roku. 


\begin{tabular}{|c|c|c|c|}
\hline 333 & Warszawa & $\begin{array}{l}\text { Klasztor Ojców Bazylianów (Biblioteka) } \\
\text { ul. Miodowa 16, 00-246 Warszawa }\end{array}$ & $\begin{array}{l}146 \text { druków w } 211 \\
\text { woluminach (druki } \\
\text { cyrylickie) (stan na } \\
2013 \text { rok) }\end{array}$ \\
\hline 334 & Warszawa & $\begin{array}{l}\text { Kolegium Zakonu Pijarów (Biblioteka) } \\
\text { ul. Gwintowa 3, 00-704 Warszawa }\end{array}$ & $\begin{array}{l}\text { brak szczegółowych } \\
\text { danych }\end{array}$ \\
\hline$\{334\}$ & $\{$ Warszawa & $\begin{array}{l}\text { \{Kuria Prowincjalna Prowincji Matki Bożej } \\
\text { Niepokalanej Zakonu Braci Mniejszych Kon- } \\
\text { wentualnych (Franciszkanie) } \\
\text { ul. Zakroczymska 1, 00-225 Warszawa\} }\end{array}$ & $\begin{array}{l}\{\text { brak szczegóło- } \\
\text { wych danych\} }\end{array}$ \\
\hline 335 & Warszawa & $\begin{array}{l}\text { Muzeum Sportu i Turystyki (Biblioteka) } \\
\text { ul. Wybrzeże Gdyńskie 4, 01-531 Warszawa }\end{array}$ & $\begin{array}{l}12 \text { druków z XVII- } \\
\text { XVIII wieku }\end{array}$ \\
\hline 336 & Warszawa & $\begin{array}{l}\text { Żydowski Instytut Historyczny im. Emanuela } \\
\text { Ringelbluma (Biblioteka) } \\
\text { ul. Tłomackie 3/5, 00-090 Warszawa }\end{array}$ & $\begin{array}{l}\text { prawie } 2500 \text { druków } \\
(\text { stan na } 2009 \text { rok) }\end{array}$ \\
\hline 337 & Wejherowo & $\begin{array}{l}\text { Muzeum Piśmiennictwa i Muzyki Kaszubsko- } \\
\text {-Pomorskiej (Dział Rękopisów i Starodruków) } \\
\text { ul. Zamkowa 2A, 84-200 Wejherowo }\end{array}$ & $\begin{array}{l}411 \text { druków } \\
(\text { stan na } 2017 \text { rok) })^{369}\end{array}$ \\
\hline 338 & Wieliczka & $\begin{array}{l}\text { Klasztor i Parafia pw. św. Franciszka z Asyżu } \\
\text { ul. br. Alojzego Kosiby 31, 32-020 Wieliczka }\end{array}$ & $\begin{array}{l}\text { brak szczegółowych } \\
\text { danych }\end{array}$ \\
\hline 339 & Wieliczka & $\begin{array}{l}\text { Muzeum Żup Krakowskich } \\
\text { ul. Zamkowa 8, 32-020 Wieliczka }\end{array}$ & $\begin{array}{l}\text { ponad } 80 \text { wolumi- } \\
\text { nów }^{371}\end{array}$ \\
\hline
\end{tabular}

365 W zbiorze tym znajdują się 64 pozycje o proweniencji z Krystynopola, 2 pozycje z Buczacza oraz pojedyncze druki z Łucka, Dobromila, Lublina, Lwówa, Mariapouczu, Białej, Zamościa i Chełmu - zob. Katalog druków cyrylicznych XVI-XVIII wieków w zbiorach biblioteki klasztoru oo. Bazylianów w Warszawie, oprac. R. Lepak, Warszawa 2013, s. 20.

366 Zob. M. Nowak, Starodruki z oficyn Prus Królewskich i Warmii w Bibliotece Warszawskiego Kolegium Pijarów (praca licencjacka), Uniwersytet Mikołaja Kopernika, Toruń 2005.

367 Najstarsze ksiażki w zbiorach Biblioteki Muzeum Sportu i Turystyki w Warszawie. Katalog, oprac. H. Jeznak, B. Mikocka, Warszawa 2009; https:/www.sendsport.pl/product-pol-552-Najstarsze-ksiazki-w-zbiorach-Biblioteki-Muzeum-Sportu-i-Turystyki-w-Warszawie-Katalog. html.

368 E. Małkowska-Bieniek, Polskie judaika jako magnes turystyczny, „Turystyka Kulturowa" 4, 2009, s. 54, http://www.turystykakulturowa.org/pdf/2009_04_02.pdf; zob. też http://www. jhi.pl/zbiory/biblioteka.

$369 \mathrm{http} / /$ www.muzeum.wejherowo.pl/d/o-muzeum/dziay/dzia-rekopisow-i-starodru kow/?cat=26. Według https://pl.wikipedia.org/wiki/Muzeum_Pi\%C5\%9Bmiennictwa_i_Muzyki_ Kaszubsko-Pomorskiej_w_Wejherowie zbiór ma liczyć 500 druków. Zob. też M. Sołtysiak, K. Wierzbicka, op. cit., s. 265.

370 Zob. https://wiadomosci.wp.pl/sprawcy-kradziezy-starodrukow-w-wieliczce-chca-dobrowolnie-poddac-sie-karze-6031694440498305a. W 2009 roku z biblioteki zginęło $250 \mathrm{ksiąg}$, w tym inkunabuły — zob. https://ksiazki.wp.pl/policja-odnalaza-skradzione-starodruki-6146230614173825a.

$371 \mathrm{http}: / /$ muzeum.wieliczka.pl/biblioteka-i-archiwum/archiwum/. 


\begin{tabular}{|c|c|c|c|}
\hline 340 & Wieliczka & $\begin{array}{l}\text { Parafia św. Klemensa (Biblioteka) } \\
\text { ul. Zamkowa 7, 32-020 Wieliczka }\end{array}$ & $\begin{array}{l}\text { co najmniej } 663 \text { dru- } \\
\text { ki, w tym } 42 \text { inku- } \\
\text { nabuły, } 277 \text { dru- } \\
\text { ków z XVI wieku } \\
\text { i } 344 \text { druki z XVII } \\
\text { wieku }^{372}\end{array}$ \\
\hline 341 & Wieluń & $\begin{array}{l}\text { Muzeum Ziemi Wieluńskiej } \\
\text { ul. Narutowicza 13, 98-300 Wieluń }\end{array}$ & $\begin{array}{l}\text { co najmniej } 1 \text { wolu- } \\
\min ^{373}\end{array}$ \\
\hline 342 & Włocławek & $\begin{array}{l}\text { Biblioteka Wyższego Seminarium Duchownego } \\
\text { im. księży Chodyńskich } \\
\text { ul. Prymasa S. Karnkowskiego 3, } \\
\text { 87-800 Włocławek }\end{array}$ & $\begin{array}{l}\text { około } 17006 \text { wolu- } \\
\text { minów, w tym } 736 \\
\text { woluminów inkuna- } \\
\text { bułów }^{374}\end{array}$ \\
\hline 343 & $\begin{array}{l}\text { Wodzisław } \\
\text { Śląski }\end{array}$ & $\begin{array}{l}\text { Muzeum (Dział historii) } \\
\text { ul. ks. płk. Wilhelma Kubsza 2, } \\
\text { 44-300 Wodzisław Śląski }\end{array}$ & $\begin{array}{l}\text { co najmniej } 18-19 \\
\text { druków }(7 \mathrm{z} \text { XVII- } \\
\text { XVIII wieku) }\end{array}$ \\
\hline 344 & Wrocław & $\begin{array}{l}\text { Archiwum Archidiecezjalne i Biblioteka } \\
\text { Kapitulna } \\
\text { ul. Kanonia 12, 50-329 Wrocław }\end{array}$ & $\begin{array}{l}\text { ponad } 40 \text { tysięcy } \\
\text { druków, w tym } \\
730 \text { inkunabułów } \\
\left(_{(\text {stan na } 2009 \text { rok) }}^{376}\right.\end{array}$ \\
\hline
\end{tabular}

372 D. Krysa, Przewodnik po gotyckim kościele p.w. św. Klemensa w Wieliczce, Wieliczka 2018, s. 23-24, http://wieliczkaklemens.pl/img/cms/gotycki_klemens_przewodnik_2018.pdf; zob. też B. Zapadlińska, Skarbiec parafialny, „Panorama Powiatu Wielickiego” 10/12, 2002, s. 1.

$373 \mathrm{http}: / / w w w . m u z e u m . w i e l u n . p l / w i e l u n / 02 /$ index.html; https:/www.e-kalejdoskop.pl/muzea-a217/ocalona-od-stosu-r1378.

374 Biblioteki Kościoła Katolickiego..., s. 130; J. Witczak, op. cit. Według T. Stolarczyka (Inwentarz inkunabułów i starych druków podominikańskich z Sieradza w Bibliotece Wyższego Seminarium Duchownego we Wtocławku, „Forum Bibliotek Medycznych” 8, 2015, nr 1 (15), s. 147, http:// digital.fides.org.pl/dlibra/doccontent?id=1701) biblioteka posiada około 20 tysięcy druków, w tym 1 tysiąc inkunabułów. W zbiorach tych znajduje się również kolekcja starych druków z Biblioteki Kapituły Katedralnej (21 inkunabułów oraz 687 pozycji w 649 woluminach druków z XVI-XVIII wieku), z byłego klasztoru dominikańskiego w Sieradzu (304 dzieła w 231 woluminach, w tym 46 inkunabułów, 94 druki z XVI wieku, 67 druków z XVII wieku oraz 24 druki z XVIII wieku) oraz księgozbiór księży Chodyńskich (1070 pozycji w 736 woluminach, w tym 127 pozycji w 129 woluminach dubletów) — zob. ibidem, s. 141; B. Iwańska-Cieślik, Biblioteka kapituły katedralnej we Włocławku, Bydgoszcz 2013, s. 191, 213-214; K. Rulka, Księgozbiór księży Chodyńskich w Bibliotece Wyższego Seminarium Duchownego we Włocławku, „Studia Włocławskie” 3, 2000, s. 418, http://bazhum.muzhp.pl/media//files/Studia_Wloclawskie/Studia_Wloclawskie-r2000-t3/ Studia_Wloclawskie-r2000-t3-s418-438/Studia_Wloclawskie-r2000-t3-s418-438.pdf.

$3 \overline{75}$ https://www.nowiny.pl/informacje/138367-muzeum-pokaze-starodruki-odnalezione-w-polomi.html; http://muzeum.wodzislaw.pl/news.php?id=216; zob. też http://muzeum.wodzislaw. $\mathrm{pl} /$ page.php?id=39.

376 Kościoly i kaplice Archidiecezji Wrocławskiej, red. J. Pater, Wrocław 2002, s. 37, https:// www.smialowice.pl/tinymce/plugins/filemanager/files/Archidiecezja.pdf; por. Biblioteki Kościoła Katolickiego..., s. 265; J. Pater, Biblioteka Kapitulna we Wroctawiu, „Fides: Biuletyn Bibliotek Kościelnych" 1-2 (24-25), (2007), s. 95, http://bazhum.muzhp.pl/media//files/Fides_Biuletyn_Bibliotek_Koscielnych/Fides_Biuletyn_Bibliotek_Koscielnych-r2007-t1_2_(24_25)/ 


\begin{tabular}{|c|c|c|c|}
\hline 345 & Wrocław & $\begin{array}{l}\text { Archiwum Państwowe (Biblioteka) } \\
\text { ul. Pomorska 2, 50-215 Wrocław }\end{array}$ & 271 woluminów 377 \\
\hline 346 & Wrocław & $\begin{array}{l}\text { Biblioteka Główna Uniwersytetu Przyrodnicze- } \\
\text { go (Zbiory specjalne) } \\
\text { ul. C.K. Norwida 29, 50-375 Wrocław }\end{array}$ & $\begin{array}{l}326 \text { druków }^{378} \\
\text { (stan na } 2009 \text { rok) }\end{array}$ \\
\hline 347 & Wrocław & $\begin{array}{l}\text { Biblioteka Papieskiego Wydziału Teologicznego } \\
\text { pl. Katedralny 14, 50-329 Wrocław }\end{array}$ & $\begin{array}{l}\text { około } 9800 \text { druków, } \\
\text { w tym } 14 \text { inkuna- } \\
\text { bułów, } 775 \text { dru- } \\
\text { ków z XVI wieku } \\
\text { oraz } 2040 \text { druków } \\
\text { z XVII wieku } \\
\text { (stan na } 2009 \text { rok) } \\
79\end{array}$ \\
\hline 348 & Wrocław & $\begin{array}{l}\text { Biblioteka Uniwersytecka } \\
\text { (Oddział Starych Druków) } \\
\text { ul. Fryderyka Joliot-Curie 12, 50-383 Wrocław }\end{array}$ & $\begin{array}{l}\text { około } 317 \text { tysięcy } \\
\text { druków w oko- } \\
\text { ło } 230 \text { tysiącach } \\
\text { woluminów, w tym } \\
3270 \text { inkunabułów, } \\
\text { około } 40 \text { tysięcy } \\
\text { druków z XVI wie- } \\
\text { ku }^{380}\end{array}$ \\
\hline
\end{tabular}

Fides_Biuletyn_Bibliotek_Koscielnych-r2007-t1_2_(24_25)-s90-97/Fides_Biuletyn_Bibliotek Koscielnych-r2007-t1_2_(24_25)-s90-97.pdf; Biblioteki naukowe Wroctawia. Informator, oprac. B. Makarska-Deszcz, Wrocław 2009, s. 69.

377 https://www.ap.wroc.pl/informacje-o-zasobie-biblioteki-archiwum. Zob. też B. Kumor, Starodruki o tematyce śląskiej w Bibliotece Archiwum Państwowego we Wrocławiu, „Roczniki Biblioteczne" 47, 2003, s. 169-200; B. Kumor-Gomułka, Biblioteka Archiwum Państwowego we Wroctawiu, [w:] Archiwum Państwowe we Wroctawiu 1811-2011. Przeszłość i współczesność, red. J. Drozd, J. Gołaszewski, Wrocław 2011, s. 192-203.

378 Biblioteki naukowe Wrocławia..., s. 28. Zob. też http://www.bibl.up.wroc.pl/ksiego.html.

379 Biblioteki naukowe Wrocławia..., s. 33. W ramach kolekcji wyróżniono ponadto prawie 200 poloników (162 notowane w BP Estreichera) oraz około 750 druków śląskich. Zob. też Starodruki cenne księgozbioru Biblioteki Głównej Papieskiego Fakultetu Teologicznego i Metropolitalnego Wyższego Seminarium Duchownego we Wrocławiu, red. A. Skura, Wrocław 1993. Według http://www.pwt.wroc.pl/biblioteka/index.php?id=4\&idp=2\&idpp=2\&lang=_pl w bibliotece znajduje się około 7500 woluminów starych druków, w tym 14 inkunabułów. Dane te powtarza również J. Witczak (op. cit.). Z kolei w Bibliotekach Kościoła Katolickiego... (s. 61) podano, że w 2005 roku w bibliotece znajdowało się około 7412 woluminów starych druków, w tym 12 woluminów inkunabułów.

$380 \mathrm{~W}$ zbiorach tych znajduje się około 10 tysięcy poloników z XVI-XVIII wieku — zob. https://www.bu.uni.wroc.pl/oddzialy/piasek/oddzial-starych-drukow-zbiory. Według https://www. bu.uni.wroc.pl/zbiory/specjalne biblioteka posiada 310 tysięcy jednostek starych druków, w tym 3200 inkunabułów oraz 2 tysiące poloników z XVI wieku. Zob. też A.F. Stenzler, Librorum saeculo XV impressorum, quos Bibliotheca Universitatis tenet, conspectus generalis, Wratislaviae 1861; B. Dudik, Karls von Žerotin Böhmische Bibliothek in Breslau, Praga 1877; H. Linke, Katalog der Lehrerbibliothek [des Elisabeth - Gymnasiums], cz. 1-3, Breslau 1895-1897; H. Mau, Katalog der mit Lehrerbibliothek des Königlichen Gymnasiums Johanneum vereinigten Bibliotheca 


\begin{tabular}{|c|c|c|c|}
\hline 349 & Wrocław & $\begin{array}{l}\text { Biblioteka Uniwersytetu Ekonomicznego } \\
\text { ul. Komandorska 118/120, 53-345 Wrocław }\end{array}$ & $\begin{array}{l}226 \text { woluminów } \\
\text { (stan na } 2016 \text { rok) }^{381}\end{array}$ \\
\hline 350 & Wrocław & $\begin{array}{l}\text { Biblioteka Uniwersytetu Medycznego } \\
\text { (Oddział Zbiorów Specjalnych) } \\
\text { ul. Marcinkowskiego 2-6, 50-368 Wrocław }\end{array}$ & $\begin{array}{l}\text { brak szczegółowych } \\
\text { danych }^{382}\end{array}$ \\
\hline 351 & Wrocław & $\begin{array}{l}\text { Biblioteka Wydziału Architektury (Politechni- } \\
\text { ka Wrocławska) } \\
\text { ul. Chemiczna 4, 50-336 Wrocław }\end{array}$ & $\begin{array}{l}\text { około } 20-30 \text { wolu- } \\
\text { minów }^{383}\end{array}$ \\
\hline
\end{tabular}

Rudolfina, cz. 1-5, Liegnitz 1905-1914; R. Mende, Katalog der Leichenpredigten - Sammlungen der Peter - Paul Kirchenbibliothek und anderer Bibliotheken in Liegnitz, Marktschellenburg 1938-1940; B. Kocowski, Historyczne podstawy organizacji zbioru starych druków w Bibliotece Uniwersyteckiej we Wrocławiu, Wrocław 1955; H. Szwejkowska, Biblioteka klasztoru cystersek w Trzebnicy, Wrocław 1955; A. Sadowska, Nieznane Estreicherom polonica w zasobie starych druków Biblioteki Uniwersyteckiej we Wrocławiu, cz. 1, „Roczniki Biblioteczne” 2, 1958, s. 155-188; eadem, Nieznane Estreicherom polonica w zasobie starych druków Biblioteki Uniwersyteckiej we Wrocławiu, cz. 2, „Roczniki Biblioteczne” 9, 1965, s. 171-197; B. Kocowski, Katalog inkunabułów Biblioteki Uniwersyteckiej we Wrocławiu, cz. 1-3, Wrocław 1959-1977; B. Górska, A. Skura, Książka polska wydawana na Śląsku w XV-XVIII w., Wrocław 1975; A. Skura, Trauerschriften vom 16. bis 18. Jahrhundert in der Universitätsbibliothek Wroctaw, [w:] Leichenpredigten als Quelle historischer Wissenschaften, T. 3, Marburg/Lahn 1984, s. 337-345; Katalog ausgewählter Leichenpredigten der ehemaligen Stadtbibliothek Breslau, oprac. R. Lenz [et al.], Marburg/ Lahn 1986; A. Skura, Katalog druków XV-XVIII w. z zakresu poetyki i retoryki, Wrocław 1987; idem, Zbiór starych druków Biblioteki Uniwersyteckiej we Wrocławiu jako źródło do badań nad dziejami ksiązki na Śląsku, „Studia o Książce” 17, 1988, s. 191-201; J. Ożóg, Katalog poloników XVI w. Biblioteki Uniwersyteckiej we Wrocławiu, T. 1-2, Wrocław 1988-1991; E. Stoeffel-Ożóg, Numizmatyka i medalierstwo; Katalog dzieł ze zbiorów Biblioteki Uniwersyteckiej we Wrocławiu, Wrocław 1992 [zawiera około 600 starych druków]; A. Skura, Catalogus van Nederland gedrukte boeken in de Univeriteitsbiblioteek van Wroctaw, Leiden 1996; idem, Stare druki, [w:] Polonica zagraniczne w Bibliotece Uniwersyteckiej we Wroctawiu. Informator, Wrocław 1998, s. 136-149.

381 A. Rogalińska, Ewolucja metod udostęniania zbiorów specjalnych, [w:] Biblioteka na miarę. Przestrzeń, zasoby, usługi, red. M. Świrad, B. Żmigrodzka, Wrocław 2016, s. 87, http:// www.dbc.wroc.pl/Content/33811/Biblioteka_na_miare_.pdf. W 2008 roku w bibliotece miały znajdować się 233 stare druki - zob. eadem, Kolekcja starych druków w Bibliotece Głównej Akademii Ekonomicznej we Wrocławiu, [w:] Ewolucja procesów bibliotecznych na tle dziejów Biblioteki Głównej Akademii Ekonomicznej we Wrocławiu, red. B. Żmigrodzka, Wrocław 2007, s. 31-46, za: E. Cieślińska, K. Żmigrodzka, Czy na pewno zagrożenie? Ksiązka cyfrowa jako alternatywa i ratunek dla książki drukowanej na przyktadzie Dolnośląskiej Biblioteki Cyfrowej, [w:] Dokąd zmierzamy? Książka i jej czytelnik: materiały z II Ogólnopolskiej Konferencji Naukowej zorganizowanej przez Bibliotekę Główna Uniwersytetu Szczecińskiego, Międzyzdroje, 20-22 września 2007 r., red. R. Gaziński, Szczecin 2008, s. 145, http://zbc.ksiaznica.szczecin.pl/Content/18106/Seria\%20BZP\%20T\%20IV.pdf. Pozycja Biblioteki naukowe Wroctawia... (s. 26) zbiór starych druków określa na „223 jedn. oblicz.”.

382 Zob. http://bg.umed.wroc.pl/biblioteka-wczoraj-i-dzis.html.

383 Informacje dr Doroty Sidorowicz-Mulak. Zob. też https://doba.pl/wroclaw/artykul/-foto-przekazanie-wladzy-na-politechnice-wroclawskiej/13742/0. 


\begin{tabular}{|c|c|c|c|}
\hline 352 & Wrocław & $\begin{array}{l}\text { Biblioteka Zakładu Narodowego } \\
\text { im. Ossolińskich (Dział Starych Druków) } \\
\text { ul. Szewska 37, 50-139 Wrocław }\end{array}$ & $\begin{array}{l}68080 \text { wolu- } \\
\text { minów, w tym } \\
485 \text { inkunabułów } \\
\text { (w } 394 \text { woluminach), } \\
7287 \text { woluminów } \\
\text { z XVI wieku, } \\
15563 \text { woluminy } \\
\text { z XVII wieku oraz } \\
42588 \text { woluminów } \\
\text { z XVIII wieku }\end{array}$ \\
\hline
\end{tabular}

384 Zbiory zawierają 3848 poloników z XVI wieku, 11848 poloników z XVII wieku oraz 23965 poloników z XVIII wieku, a także 554 tytuły (w 2150 woluminów) czasopism oraz 98 woluminów muzykaliów - zob. https://ossolineum.pl/index.php/biblioteka-osolineum/dzialy-i-gabinety/ dzial-starych-drukow/. Zob. też K. Heintsch, Fragment druku Świętopełka Fiola w Bibliotece Zakładu im. Ossolińskich, „Ze Skarbca Kultury” 1953, z. 2 (5), s. 78-94; K. Schuster, Fragment biblioteki Łukasza Opalińskiego w Ossolineum, ,Ze Skarbca Kultury” 1955, z. 1 (7), s. 219-245; Katalog inkunabułów Biblioteki Zakładu Narodowego im. Ossolińskich we Wrocławiu, na podstawie materiałów K. Piekarskiego oprac. A. Kawecka-Gryczowa, Wrocław 1956; K. Zathey, Księgozbiór starych druków Biblioteki Zakładu im. Ossolińskich we Wrocławiu, ,Rocznik Zakładu Narodowego im. Ossolińskich" 5, 1957, s. 677-682; H. Oprawko, J. Seifert-Mechowa, Materiaty bibliograficzne XVII i XVIII wieku ze zbioru poloników Biblioteki Zakładu Narodowego im. Ossolińskich we Wrocławiu, „Roczniki Biblioteczne” 4, 1960, s. 521-581; eidem, Materiaty bibliograficzne XVII i XVIII wieku ze zbioru poloników Biblioteki Zakładu Narodowego im. Ossolińskich we Wrocławiu, „,Roczniki Biblioteczne" 8, 1964, s. 189-233; J.A. Kosiński, Fragment księgozbioru Piotra Kmity w Bibliotece Ossolineum, „Ze Skarbca Kultury” 1964, z. 16, s. 116-132; J.A. Kosiński, J. Szczepaniec, Rękopiśmienne dedykacje autorskie XVI-XVIII w. w zbiorach starych druków Biblioteki Ossolineum, „Ze Skarbca Kultury” 1964, z. 16, s. 187-213; Katalog starych druków Biblioteki Zakładu Narodowego im. Ossolińskich. Polonica wieku XVI, z materiałów rejestracyjnych K. Zatheya oprac. M. Bohonos, Wrocław 1965; J.A. Kosiński, Monumenta Zygmunta Augusta w zbiorach Ossolineum, „Roczniki Biblioteczne" 11, 1967, nr 1-2, s. 407-423; B. Górska, Katalog kalendarzy XVII-XVIII w. w zbiorach Biblioteki Ossolineum, Wrocław 1968; eadem, Katalog czasopism XVI-XVIII w. w zbiorach Starych Druków Biblioteki Ossolineum, „Ze Skarbca Kultury” 1969, z. 15, s. 7-262; E. Triller, Katalog inkunabułów Biblioteki Zakładu Narodowego im. Ossolińskich we Wrocławiu. Kontynuacja katalogu Alodii Kaweckiej-Gryczowej, „Ze Skarbca Kultury” 1969, z. 15, s. 263-290; idem, Materiaty do bibliografii druków urzędowych XVIII w. w Polsce w zbiorach Biblioteki Zaktadu Narodowego im. Ossolińskich, „Ze Skarbca Kultury” 1969, z. 20, s. 211-274; J. Szczepaniec, Mikołaj Rej na tle epoki $i w$ tradycji - wystawa w Bibliotece Ossolineum z okazji czterechsetnej rocznicy śmierci Reja, „Ze Skarbca Kultury” 1970, z. 21, s. 265-280; B. Górska, Bresslauischer Mercurius auss dem Königreich Pohlen 1697-1699, „Ze Skarbca Kultury” 1972, z. 23, s. 253-269; J. Szczepaniec, Co to jest być prawdziwym patriota? - jakobińska broszura z 1794 r. Zagadnienia autorstwa i tekstu, „Ze Skarbca Kultury” 1973, z. 24, s. 25-56; Z.M. Zachmacz, Komisja Edukacji Narodowej na tle epoki, Wrocław 1973; B. Górska, Książka polska wydawana na Śląsku w XV-XVIII wieku, wstępem poprzedził A. Skura, Wrocław 1975; eadem, Stanisława Orzechowskiego „Policyja Królestwa Polskiego” - fragment nieznanego druku z XVI w., „Ze Skarbca Kultury” 1976, z. 27, s. 5-12; Skarby kultury narodowej: ze zbiorów Biblioteki Narodowej, Jagiellońskiej i Ossolineum, red. T. Rabek, Wrocław 1978; W. Tyszkowski, Z cenzorskiej działalności Jurysdykcji Marszałkowskiej w Warszawie. Spalenie numeru „Gazette d' Utrecht” z 21 czerwca 1768 r., „Ze Skarbca Kultury” 1980, z. 33,

\section{ROCZNIKI BIBLIOTECZNE}

ROK LXIII, 2019

(C) for this edition by CNS 
s. 95-104; B. Górska: Nordischer Mercurius (1683-1684) w zbiorach Biblioteki Ossolineum, „Ze Skarbca Kultury” 1984, z. 40, s. 21-57; Katalog starych druków Biblioteki Zakładu Narodowego im. Ossolińskich. Polonica wieku XVII, T. 1-2, oprac. B. Górska, W. Tyszkowski, Wrocław 19911992; Katalog starych druków Biblioteki Zakładu Narodowego im. Ossolińskich. Polonica wieku XVII, T. 2-8, oprac. W. Tyszkowski, Wrocław 1993-1996; Katalog starych druków Biblioteki Zakładu Narodowego im. Ossolinskich. Polonica wieku XVII, T. 9, oprac. G. Rolak, W. Tyszkowski, Wrocław 1997; W. Tyszkowski, Polskie katalogi księgarskie z XVIII w., w zbiorach Biblioteki Ossolineum, „Ze Skarbca Kultury” 1986, z. 42, s. 35-92; idem, Walenty Bogustaw Szypiński. Wiersz weselny na ślub Filipa Bokija i Zofii Zawadzkiej (r. 1645), „Genealogia” 2, 1992, s. 87-103; M. Góralska, Fragment księgozbioru Michała Hieronima Juszyńskiego w Bibliotece Ossolineum, „Czasopismo Zakładu Narodowego imienia Ossolińskich” 5, 1994, s. 161-180; M.K. Sulowski, Zakony i klasztory, z których pochodza druki z XV, XVI, XVII wieku znajdujace się w zbiorach Biblioteki Zakładu Narodowego im. Ossolinskich (praca magisterska), Uniwersytet Wrocławski, Wrocław 1994; Emblematy w ossolińskich zbiorach druków i rękopisów XVI-XVIII w., oprac. D. Platt, Wrocław 1995; E. Piasecka-Szczerbińska, Bibliotheca Brodzkiana - zbiory Eugeniusza Brodzkiego w Zakładzie Narodowym im. Ossolińskich, Wrocław 1996; Stanisław Staszic — patron Miejskiej Biblioteki w Lubinie, oprac. J. Grześkowiak, Wrocław-Lubin 1996; W. Tyszkowski, [Anonima] Oda na dzień weselny Feliksa Olędzkiego i Róży Węgleńskiej (r. 1775), „Genealogia” 7, 1996, s. 115-118; Katalog der Leichenpredigten und sonstiger Trauerschriften in der Bibliothek des Ossolineums Wroctaw (Breslau), oprac. R. Lenz [et al.], Sigmarinen 1998; J. Długosz, Ossoliński zbiór rękopiśmiennych dedykacji autorskich i proweniencyjnych, „Czasopismo Zakładu Narodowego imienia Ossolińskich” 10, 1999, s. 243-250; M. Pidłypczak-Majerowicz, Ksiegozbiory zakonne w Zakładzie Narodowym im. Ossolinskich we Wrocławiu, „Czasopismo Zakładu Narodowego imienia Ossolińskich” 10, 1999, s. 281-294; W. Tyszkowski, Kolekcja poloników XVII w. Zakładu Narodowego im. Ossolińskich we Wrocławiu — próba charakterystyki, „Czasopismo Zakładu Narodowego imienia Ossolińskich” 10, 1999, s. 275-281; G. Rolak, Anonima ,Pulcheryja” albo Pandora polska” z 1774 r., „Czasopismo Zakładu Narodowego imienia Ossolińskich" 11, 2000, s. 137-151; W. Tyszkowski, Zarys historii Dziatu Starych Druków Zakładu Narodowego im. Ossolińskich 1918-1998, „Czasopismo Zakładu Narodowego imienia Ossolińskich" 11, 2000, s. 217-226; J. Długosz, Nowe możliwości badań proweniencyjnych starych druków, „Czasopismo Zakładu Narodowego imienia Ossolińskich” 12, 2001, s. 175-183; W. Tyszkowski, Ryciny Henryka Czecha w zbiorach starych druków Ossolineum, „Czasopismo Zakładu Narodowego imienia Ossolińskich" 12, 2001, s. 169-174; idem, Z problematyki badań proweniencyjnych. Fragment Biblioteki ks. Lubomirskich w Przeworsku w zbiorach starych druków Ossolineum. Komunikat, „Czasopismo Zakładu Narodowego imienia Ossolińskich” 12, 2001, s. 185-187; Biblia: stowo i obraz. Katalog wystawy, kwiecień 2002, oprac. M. Orzeł, G. Rolak, W. Tyszkowski, Wrocław 2002; J. Długosz, Dedykacje autorskie na książkach ofiarowanych Władysławowi Dominikowi Ostrogskiemu-Zasławskiemu (1616-1656), „Czasopismo Zakładu Narodowego imienia Ossolińskich” 13, 2002, s. 7-11; G. Rolak, Fragment księgozbioru Józefiny z Mniszchów Potockiej w zbiorach DziaŁu Starych druków ZNiO, „Czasopismo Zakładu Narodowego imienia Ossolińskich” 13, 2002, s. 137 176; W. Tyszkowski, Produkcja drukarni Jana Filipowicza we Lwowie, „Czasopismo Zakładu Narodowego imienia Ossolińskich” 13, 2002, s. 13-37; idem, Na tropach nieznanej drukarni w Zamościu, „Czasopismo Zakładu Narodowego imienia Ossolińskich” 14, 2003, s. 109-118; G. Rolak, W kręgu Potockich z Tulczyna. Fragment kolekcji Biblioteki Tulczyńskiej w zbiorach Dziatu Starych Druków Zakładu Narodowego im. Ossolińskich, „Czasopismo Zakładu Narodowego imienia Ossolińskich” 15, 2004, s. 157-181; Mundus Mercatorius. Świat kupiecki czasów nowożytnych w miarach i dokumentach. Katalog wystawy kwiecień-lipiec 2005, wstęp i układ katalogu R. Skowron, red. M. Orzeł, Wrocław 2005; G. Rolak, Dzieło Komisji przez delegację Rzeczypospolitej wyznaczonej do poznania pretensji Zakonu Maltańskiego. Na podstawie druku z 1774 r., „Czasopismo Zakładu Narodowego imienia Ossolińskich" 16, 2005, s. 115-137; idem, Z Afryki do Polski. Dar Eustachego Sapiehy dla 


\begin{tabular}{|c|l|l|l|}
\hline 353 & Wrocław & $\begin{array}{l}\text { Muzeum Narodowe (Biblioteka) } \\
\text { pl. Powstańców Warszawy 5, 50-153 Wrocław }\end{array}$ & $\begin{array}{l}\text { 1501 druków } \\
\text { w 1259 woluminach } \\
(\text { stan na 2018 rok })^{385}\end{array}$ \\
\hline
\end{tabular}

Ossolineum, „Czasopismo Zakładu Narodowego imienia Ossolińskich” 17, 2006, s. 155-175; D. Sidorowicz, Spod wrocławskich pras. Nowe nabytki Działu Starych Druków ZNiO, „Czasopismo Zakładu Narodowego imienia Ossolińskich” 17, 2006, s. 145-154; Wszystkie Modlitwy Rzeczypospolitej. Katalog wystawy 3 lipca-30 sierpnia 2009, oprac. katalogu D. Sidorowicz, Wrocław 2009; D. Sidorowicz, Gromadzenie i opracowanie starych druków w Zakładzie Narodowym im. Ossolińskich. Historia, wspótczesność, perspektywy, [w:] L'vivska nacional'na naukova biblioteka Ukrä̈ni imieni V. Stefanika, istorija i sučasnist, L'viv 2010; D. Sidorowicz, M. Grocholska, Konserwacja i digitalizacja zbiorów biblioteki Zakładu Narodowego im. Ossolińskich we Wrocławiu, [w:] Między teoria a praktyka. Ochrona zbiorów w małych bibliotekach i archiwach, red. A. Czajka, R. Lis, Cieszyn 2010 (e-book); D. Sidorowicz, Digitalizacja starych druków biblioteki Zakładu Narodowego im. Ossolinskich we Wrocławiu, [w:] Wykorzystanie funduszy europejskich w bibliotece Ossolineum i Książnicy Cieszyńskiej, red. B. Bednarska-Michalska, Wrocław-Toruń 2010; D. Sidorowicz-Mulak, Profil gromadzenia starych druków, „Czasopismo Zakładu Narodowego imienia Ossolińskich” 22, 2011, s. 267-269; eadem, Ossolińskie stare druki w Sieci. Opracowanie i udostępnianie, [w:] Dobra kultury w Sieci, red. E. Herden, A. Seidel-Grzesińska, K. Stanicka-Brzezicka, Wrocław 2012; A. Franczyk-Cegła, Fragmenty księgozbioru klasztoru karmelitów w Sąiadowicach w zbiorach Zakładu Narodowego im. Ossolińskich, „Hereditas Monasteriorum” 6, 2015, s. 117-156; D. Sidorowicz-Mulak, Z królewskich księgozbiorów XVII-XVIII wieku. Oprawy z superekslibrisami polskich królów i królowych ze zbiorów Ossolineum, [w:] Tegumentologia polska dzisiaj, red. A. Wagner, Toruń 2015, s. 299-324; D. Sidorowicz-Mulak, A. Wagner, Dzieło Vesaliusa w oprawie Mistrza Dawida a problem początków księgozbioru króla Zygmuna Augusta, „Roczniki Biblioteczne” 59, 2015, s. 3-24; A. Franczyk-Cegła, Podróże i odkrycia geograficzne na kartach osiemnastowiecznych starych druków, [w:] W czwartek o szesnastej. Wybrane wyktady ossolińskie z lat 2014-2016, red. T. Sokół, Wrocław 2016, s. 15-38; D. Sidorowicz-Mulak, Królewskie księgi w Ossolineum i ich proweniencje. O kilkunastu woluminach z biblioteki Zygmunta Augusta, [w:] W czwartek o szesnastej..., s. 151-172; A. Franczyk-Cegła, Francuskie cymelia w zbiorach Działu Starych Druków Zakładu Narodowego im. Ossolińskich, „Czasopismo Zakładu Narodowego imienia Ossolińskich” 26-27, 2016, s. 9-45; eadem, Zarys dziejów klasztoru oo. karmelitów w Sąiadowicach, „Nasza Przeszłość” 2016, nr 125, s. 75-126; eadem, Pinocciana w zbiorach Działu Starych Druków Zakładu Narodowego im. Ossolińskich, „Z Badań nad Książką i Księgozbiorami Historycznymi” 10, 2016, s. 59-78; eadem, Nieznany prognostyk astrologiczny Jana z Głogowa na 1505 rok, „Czasopismo Zakładu Narodowego imienia Ossolińskich" 28, 2017, s. 145-158; eadem, Inkunabuły i szesnastowieczne polonika z kolekcji Ossolineum, „Spotkania z Zabytkami” 2017, nr 9-10, s. 49-52; eadem, Zbiory ksiażkowe Biblioteki im. Gwalberta Pawlikowskiego, „Galicja. Studia i Materiały” 2017, nr 3, s. 121-146; eadem, Книгозбірня оо. кармелітів з Сусідовичів у зібраннях Львівської Начіональної Наукової Бібліотеки України ім. В. Стефаника і Національного Закладу ім. Оссолінських у Вроилаві, „Zapyski Lwiwskoji Naukowoji Biblioteky im. W. Stefanyka” 2017, nr 25, s. 24-57; Katalog druków XVI wieku z historycznej kolekcji Ossolineum, red. D. Sidorowicz-Mulak, Wrocław 2017; D. Sidorowicz-Mulak, Dziat Starych Druków ZNiO i jego kolekcja, [w:] Nie tylko książki. Ossolińskie kolekcje i ich opiekunowie, red. M. Dworsatschek, Wrocław 2018, s. 103-147.

385 B. Fercowicz, M. Piotrowska, Sztuka druku. Europejskie oficyny wydawnicze w starodrukach biblioteki Muzeum Narodowego we Wroctawiu. Katalog wystawy, Wrocław 2018, s. 7-8; zob. też https://mnwr.pl/wizyta/biblioteka/; https://mnwr.pl/sztuka-druku/.

\section{ROCZNIKI BIBLIOTECZNE}

ROK LXIII, 2019

(C) for this edition by CNS 


\begin{tabular}{|c|c|c|c|}
\hline 354 & Wschowa & $\begin{array}{l}\text { Klasztor Zakonu Braci Mniejszych - } \\
\text { Franciszkanie (Biblioteka) } \\
\text { ul. Klasztorna 2, 67-400 Wschowa }\end{array}$ & $\begin{array}{l}\text { co najmniej } \\
832 \text { druki, w tym } \\
45 \text { inkunabułów, } \\
285 \text { druków z XVI } \\
\text { wieku oraz } 402 \text { dru- } \\
\text { ki z XVII wieku }{ }^{386}\end{array}$ \\
\hline 355 & Wschowa & $\begin{array}{l}\text { Muzeum Ziemi Wschowskiej } \\
\text { (Biblioteka Naukowa) } \\
\text { pl. Zamkowy 2, 67-400 Wschowa }\end{array}$ & $\begin{array}{l}\text { brak szczegółowych } \\
\text { danych }^{387}\end{array}$ \\
\hline 356 & Zabrze & $\begin{array}{l}\text { Miejska Biblioteka Publiczna } \\
\text { im. Jerzego Fusieckiego } \\
\text { ul. ks. Józefa Londzina 3, 41-800 Zabrze }\end{array}$ & 16 woluminów 388 \\
\hline 357 & Zabrze & $\begin{array}{l}\text { Muzeum Górnictwa Węglowego (Biblioteka) } \\
\text { ul. Jodłowa 59, 41-800 Zabrze }\end{array}$ & $\begin{array}{l}\text { brak szczegółowych } \\
\text { danych }\end{array}$ \\
\hline 358 & Zakliczyn & $\begin{array}{l}\text { Klasztor i Parafia pw. Matki Bożej Anielskiej } \\
\text { ul. Klasztorna 2, 32-840 Zakliczyn }\end{array}$ & $\begin{array}{l}\text { brak szczegółowych } \\
\text { danych }{ }^{390}\end{array}$ \\
\hline 359 & Zakroczym & $\begin{array}{l}\text { Biblioteka Prowincjonalna Klasztoru Braci } \\
\text { Mniejszych Kapucynów/Centrum Duchowości } \\
\text { „Honoratianum” } \\
\text { ul. O. Honorata Koźmińskiego 36, } \\
\text { 05-170 Zakroczym }\end{array}$ & $\begin{array}{l}9860 \text { druków, w tym } \\
33 \text { inkunabuły } \\
\text { (stan na } 2007 \text { rok) }^{391}\end{array}$ \\
\hline
\end{tabular}

386 Wśród zbiorów tych 274 tytułów to wydania polskie — zob. https://www.winobranie.pl/ artykuly.php/6/213,klasztor_franciszkanow_we_wschowie. Zob. też K. Soliński, Biblioteka kościoła ewangelickiego imienia Żłóbka Chrystusa (Kripplein Christi) we Wschowie w świetle fragmentu jej księgozbioru w zasobach Biblioteki Narodowej oraz innych źródet, „Rocznik Biblioteki Narodowej” 47, 2016, s. 25-50.

387 Zob. http://muzeum.wschowa.pl/zbiory/; ,,Soli Deo Gloria”. Protestanckie dziedzictwo kulturowe Ziemi Wschowskiej w XVI-XVIII wieku, red. M. Małkus, K. Szymańska, Wschowa 2014, http://muzeum.wschowa.pl/pliki/soli_deo_gloria.pdf; http://muzeum.wschowa.pl/2016/06/23/kronika-lauterbacha-nowy-nabytek-w-muzeum-ziemi-wschowskiej/.

388 Dane na podstawie kwerendy M. Kycler.

389 W zbiorach muzeum znajduje się 150 starych druków i druków rzadkich — zob. http:// krajoznawca.org/kg17/258-spacer-po-centrum-zabrza. Zob. też https://muzeumgornictwa.pl/o-muzeum/biblioteka.

390 Zob. http://www.zakliczyn.com/zakliczyn/oo.php.

391 G. Filipiuk, Archiwum i biblioteka Warszawskiej Prowincji Kapucynów w Zakroczymiu, „Fides: Biuletyn Bibliotek Kościelnych” 1-2 (24-25), 2007, s. 113, http://bazhum.muzhp.pl/media// files/Fides_Biuletyn_Bibliotek_Koscielnych/Fides_Biuletyn_Bibliotek_Koscielnych-r2007-t1_2_ (24_25)/Fides_Biuletyn_Bibliotek_Koscielnych-r2007-t1_2_(24_25)-s103-117/Fides_Biuletyn_ Bibliotek_Koscielnych-r2007-t1_2_(24_25)-s103-117.pdf. Według J. Witczaka (op. cit.) w bibliotece znajduje się 7500 starych druków, w tym 33 inkunabuły. Według http://www.kapucyni-nm. pl/historia-klasztoru/w bibliotece klasztornej zgromadzono około 10 tysięcy starych druków. Zob. też http://wyborcza.pl/1,75248,1344107.html. 


\begin{tabular}{|c|l|l|l|}
\hline 360 & Zamość & $\begin{array}{l}\text { Archiwum i Biblioteka Diecezjalna } \\
\text { ul. Zamoyskiego 1, 22-400 Zamość }\end{array}$ & 1982 woluminy \\
\hline 361 & Zamość & $\begin{array}{l}\text { Książnica Zamojska im. Stanisława Kostki } \\
\text { Zamoyskiego (Dział Informacji, Bibliografii } \\
\text { i Wiedzy o Regionie) } \\
\text { ul. Kamienna 20, 22-400 Zamość }\end{array}$ & $\begin{array}{l}\text { 47 druków (w 37 } \\
\text { woluminach) }\end{array}$ \\
\hline 362 & Zamość & $\begin{array}{l}\text { Muzeum Zamojskie } \\
\text { ul. Ormiańska 30, 22-400 Zamość }\end{array}$ & 207 woluminów $^{394}$ \\
\hline 363 & Zawiercie & $\begin{array}{l}\text { Miejska i Powiatowa Biblioteka Publiczna } \\
\text { Miejska } \\
\text { ul. Szymańskiego 2, 42-400 Zawiercie }\end{array}$ & 2 woluminy \\
\hline 364 & $\begin{array}{l}\text { Zduńska } \\
\text { Wola }\end{array}$ & $\begin{array}{l}\text { Biblioteka Domu Misyjnego Wyższego } \\
\text { Seminarium Duchownego Księży Orionistów } \\
\text { ul. Laska 88, 98-220 Zduńska Wola }\end{array}$ & 116 woluminów $^{396}$ \\
\hline 365 & Zielona Góra & $\begin{array}{l}\text { Wojewódzka i Miejska Biblioteka Publiczna } \\
\text { imienia Cypriana Norwida } \\
\text { al. Wojska Polskiego 9, 65-077 Zielona Góra }\end{array}$ & 2400 druków $^{397}$ \\
\hline
\end{tabular}

392 Biblioteki Kościoła Katolickiego..., s. 269; zob. też https://diecezja.zamojskolubaczowska.pl/kuria/muzeum-i-archiwum-diecezjalne.

393 Dane na podstawie kwerendy M. Kycler. Od 2008 roku w depozycie znajduje się również ponad 6500 jednostek wchodzących w skład kolekcji „Księgozbiór Klemensowski Rodziny Zamoyskich". Zob. też R. Pałczyńska, Starodruki w zbiorach Wojewódzkiej i Miejskiej Biblioteki Publicznej w Zamościu, „Bibliotekarz Zamojski” 1, 1997, s. 14-18 oraz „Zamojski Kwartalnik Kulturalny" 1, 1997, s. 26-29; P. Bartnik, Radełka Jagiellońskie na oprawach starodruków z Biblioteki Kolegiackiej w Zamościu (praca magisterska), Uniwersytet Marii Curie-Skłodowskiej, Lublin 1999.

394119 z tych woluminów było drukowanych w Zamościu — zob. http://muzeum-zamojskie. pl/455; http://muzeum-zamojskie.pl/stdruk/. Zob. też M. Sołtysiak, K. Wierzbicka, op. cit., s. 286.

395 Dane na podstawie kwerendy M. Kycler.

396 Biblioteki Kościoła Katolickiego..., s. 163; zob. też M. Borkowska-Kurek, Stare druki i druki XIX-wieczne Biblioteki Księży Orionistów w Zduńskiej Woli (praca magisterska), Uniwersytet Łódzki, Łódź 1985.

397 Dane na podstawie kwerendy M. Kycler. Według https://polska-org.pl/4603279,foto.html w 1978 roku w bibliotece znajdowało się około 1950 woluminów starych druków. Z kolei http:// stare.biblioteki.org/repository/PROJEKT\%2018/Strategie\%20WBP/Wojewodzka_i_Miejska_Biblioteka_Publiczna_w_Zielonej_Gorze.pdf podaje, iż w bibliotece mieści się 67 tysięcy jednostek zbiorów specjalnych (między innymi starodruków i zabytkowej kartografii). Zob. też A. Lipińska, Ciekawsze ślaskie starodruki w Dziale Zbiorów Specjalnych WiMBP im. C. Norwida w Zielonej Górze, „Pro Libris” 2, 2002, s. 96-99. 


\begin{tabular}{|c|l|l|l|}
\hline 366 & Zielona Góra & $\begin{array}{l}\text { Biblioteka Uniwersytecka } \\
\text { (Dział Zbiorów Specjalnych) } \\
\text { (w jej skład włączono Bibliotekę Wyższej } \\
\text { Szkoły Pedagogicznej oraz Bibliotekę Główną } \\
\text { Politechniki Zielonogórskiej) } \\
\text { al. Wojska Polskiego 71, 65-762 Zielona Góra }\end{array}$ & $\begin{array}{l}\text { 1740 druków } \\
\text { (stan na 2018 rok) }\end{array}$ \\
\hline 367 & Zielona Góra & $\begin{array}{l}\text { Pedagogiczna Biblioteka Wojewódzka } \\
\text { im. Marii Grzegorzewskiej } \\
\text { al. Wojska Polskiego 9, 65-077 Zielona Góra }\end{array}$ & $\begin{array}{l}\text { brak szczegółowych } \\
\text { danych }\end{array}$ \\
\hline 368 & Żagań & $\begin{array}{l}\text { Poaugustiański zespół klasztorny (Biblioteka) } \\
\text { Parafia pw. Wniebowzięcia Najświętszej } \\
\text { Maryi Panny } \\
\text { pl. Klasztorny 2, 68-100 Żagań }\end{array}$ & $\begin{array}{l}\text { ponad 2 tysiące } \\
\text { druków, wym } \\
64 \text { inkunabuły } 400\end{array}$ \\
\hline 369 & Żarnowiec & $\begin{array}{l}\text { Opactwo Benedyktynek } \\
\text { Klasztorna 1, 84-110 Krokowa }\end{array}$ & $\begin{array}{l}\text { 97 woluminów, } \\
\text { w tym 15 wolumi- } \\
\text { nów z XVI wieku } \\
\text { i 82 woluminy } \\
\text { z XVII-XVIII } \\
\text { wieku (stan na 2017 } \\
\text { rok) }\end{array}$ \\
\hline
\end{tabular}

Źródło: opracowanie własne.

KONRAD K. SZYMAŃSKI

\section{MATERIAL FOR THE STUDY OF THE STATE OF EARLY PRINTED BOOK COLLECTIONS IN POLAND}

\section{Summary}

One of the planned tasks of the Provenance Working Group (coordinated by the Ossoliński National Institute) for 2018 was to compile a list of libraries with early printed books in their collec-

398 https://gazetalubuska.pl/jakie-skarby-skrywa-biblioteka-uz-maja-po-500-lat-zdjecia/ ar/13128694. Według http://www.bu.uz.zgora.pl/index.php/pl/informacje/o-nas/o-bibliotece rękopisy i stare druki zgromadzone w bibliotece stanowią 2308 jednostek.

399 Na stronie internetowej biblioteki (https://www.pbw.zgora.pl/pbw/Cymelia\%20pbw) prezentowane są obecnie 2 stare druki.

$400 \mathrm{http} / / /$ www.krajoznawcy.info.pl/dziedzictwo-braci-augustianow-7493; https://gazetalubuska.pl/na-rowerowym-szlaku-zagania-odkryjemy-niejedno-ciekawe-miejsce/ar/8171838; http://www. znaczki-turystyczne.pl/znaczkowe-miejsca-turystyczne/zespol-poaugustianski-w-zaganiu-c321.

401 M. Pronobis-Gajdzis, M. Kłosiewicz, G.B. Nehring, Rola zabytkoznawczej analizy wartościującej w ustalaniu priorytetów konserwatorskich. Przypadek księgozbioru starych druków z opactwa Benedyktynek w Żarnowcu, „Toruńskie Studia Bibliologiczne” 2017 nr 2 (19), s. 11, http://apcz.umk.pl/czasopisma/index.php/TSB/article/download/TSB.2017.015/14132; zob. też E. Jesipowicz, Zbiór starych druków w klasztorze Sióstr Benedyktynek w Żarnowcu (praca magisterska), Uniwersytet Gdański, Gdańsk 1979.

\section{ROCZNIKI BIBLIOTECZNE}

ROK LXIII, 2019

(C) for this edition by CNS 
tions. The main objective was to disseminate information about institutions having books printed in the fifteenth-eighteenth centuries in their collections, which in turn would provide scholars studying early printed books in Poland with an insight into the current situation. Common access to the current and, as far as possible, complete data about these collections remains a proposal of librarians from the previous century that is yet to be implemented. The compilation presented here, based largely on public domain data as well as data from printed publications, is an expanded version of the compilation mentioned above. In its present form the material contains a table featuring information about over 369 institutions with early printed books in their holdings in Poland, located in over 163 towns and cities. They include the biggest collections as well as smaller holdings of academic and public libraries or libraries of church institutions, museums and archives all over the country. For most of these sites it has been possible to find, in addition to their current addresses, more or less basic data about their collections of early printed books. Another objective of the present publication - in addition to presenting information about the location and size of the collections - is to examine the condition and quality of information about them. There is still a lot to be done in this respect. Therefore, it is to be hoped that the material presented here will become an inspiration for a verification of the data collected in it as well as a discussion about a common methodology for creating a comprehensive and as complete as possible guide to early printed books in Poland.

KEY WORDS: early printed books, libraries, museums, archives, scholarly information, Poland 